JOÃO FELIPE GUIMARÃES DE MACEDO SALES DOMICIANO

\title{
O mito e sua estrutura: contribuições da antropologia lévi-straussiana para a formalização da clínica psicanalítica
}

\author{
Dissertação apresentada ao \\ Instituto de Psicologia da \\ Universidade de São Paulo, \\ como parte dos requisitos para \\ a obtenção do grau de Mestre \\ em Psicologia \\ Área de concentração: \\ Psicologia Clínica \\ Orientador: Prof. Livre-Docente \\ Christian Ingo Lenz Dunker
}


Domiciano, João Felipe Guimarães de Macedo Sales.

O mito e sua estrutura: contribuições da antropologia lévi-straussiana para a formalização da clínica psicanalítica / João Felipe Guimarães de Macedo Sales Domiciano; orientador Christian Ingo Lenz Dunker. -- São Paulo, 2014.

$290 \mathrm{f}$.

Dissertação (Mestrado - Programa de Pós-Graduação em Psicologia. Área de Concentração: Psicologia Clínica) - Instituto de Psicologia da Universidade de São Paulo.

1. Mito 2. Antropologia 3. Estrutura 4. Psicanálise I. Título.

$\mathrm{RC} 504$ 
DOMICIANO, J. F. G. M. S. O mito e sua estrutura: contribuições da antropologia lévi-straussiana para a formalização da clínica psicanalítica. Dissertação apresentada ao Instituto de Psicologia da Universidade de São Paulo para obtenção do grau de Mestre em Psicologia.

Aprovado em:

Banca examinadora

Prof. Dr.:

Instituição: Assinatura:

Prof. Dr.:

Instituição: Assinatura:

Prof. Dr.:

Instituição: Assinatura: 
A José e Vanessa, passado e presente. 


\section{AGRADECIMENTOS}

Ao Christian Dunker, pela infinita generosidade, coragem e companheirismo nesta aventura de promover encontros improváveis. Sua entrega à atividade de pesquisa e disposição a deslocar-se dos lugares comuns serviram de inspiração desde os primeiros passos desta jornada.

Ao Renato Sztutman e José Miguel Bairrão, pelas preciosas contribuições no exame de qualificação.

À Capes, pelo financiamento que tornou possível a concretização deste trabalho.

Ao Paulo Endo, por ter me acolhido na grata experiência do Estágio Supervisionado em Docência do Programa de Aperfeiçoamento de Ensino (ESD-PAE).

Ao Daniel Kupermann, Nelson da Silva Jr., Miriam Debieux, Sidi Askofaré, Sandra Berta e Conrado Ramos, que em contextos mais ou menos formais contribuíram para a produção de novos questionamentos. Especialmente a César Ades (in memorian), grande incentivador deste mestrado e com quem iniciei a atividade de pesquisa acadêmica.

Ao Raul Pacheco, pela escuta precisa e intervenções decisivas nos mais diversos momentos desta jornada.

Aos colegas de orientação, interlocutores privilegiados e determinantes no percurso de escrita: Maria Letícia Reis, Daniele Sanchez, Luciana Salum, Cris Mathias, Hugo Lana, Rafael Lima, Marcelo Checchia, Rafael Cossi, Roberto Propheta, Karen Alves, Ligia Borba, Clovis Zanetti, Ronaldo Torres, Abenon Menegassi, Paulo Rona, Jonas Boni, Fuad Kyrillos, Tatiana Assadi, Pedro Castilho, Dulce Coppedê, Leandro dos Santos, Stella Ferraretto, Madalena Becker e Valesca Bertanha. Mais que parceiros em inúmeros projetos paralelos, encontrei aí amigos para compartilhar grandes momentos. 
Aos colegas de consultório: Anna Turriani, Maíra Marques, Roberto Marques, Luiz Bruder, Lilian Andrade, Clarice Paulon e Lucas Bulamah. Pelos cafés e conversas na cozinha.

Aos colegas de Latesfip, em especial ao grupo "Narcisismo", no qual trabalhei diretamente, mesmo que nem sempre presente: Ronaldo Manzi, Rafael Gargano, Hélgis Cristófaro, Maria Nakasu, Silvio Carneiro e Roberto Marques.

Aos colegas do grupo de estudos dos Seminários: Bia Waldvogel, Esperança Moraes, Débora Cardillo, Sávia Emrich, Fernanda Sato, André Nader, Renata Brandstatter, Mayra Xavier e Patrícia Brandstatter. Em especial a Michele Faria, por sustentar aí um espaço de franca interlocução e debate dos meandros da obra lacaniana.

Aos amigos e colegas que estiveram presentes em tantos momentos deste percurso: Michelle Araújo, Ingrid Zia, Camila Oliveira, Cibele Yamamoto, Denise Synthes, Heloísa Ramirez, Pedro Ambra, Paulo Beer, Ludu Vasconcelos, Chris Haritçalde, Luiz Botto, Eveline Araújo, Aline Martins, Francisco Capoulade, Viviana Venosa, Débora Moraes, Ypuan Garcia. Agradeço ainda ao Luiz Moreno pelo grande auxílio na língua grega, e ao Ael Salebian pela amizade de todas as horas.

Aos colegas psicanalistas do $\mathrm{ABC}$, que me mostraram que a política da psicanálise se faz pela e através da ação, do movimento: Leo Pereti, Renata Rampim, Karla Xavier, Brendali Dias, João Ezequiel, Leandro dos Santos, Daniel Vitorello, Conceição Sperini, Flávia Reigado, Angélica Hoffler e Paulo Perez. Agradeço ainda a Tiago Sanchez (UMESP), Heliane Silva (Uniban) e Sandra Magri (Faculdade de Medicina do $\mathrm{ABC}$ ) pelos convites a dar os primeiros passos na atividade de docência.

À Cícera e Cláudia, da secretaria do Departamento de Psicologia Clínica, por tornarem menos penosa a assombrosa burocracia universitária.

À Aurélia e Marco, que nos últimos tempos deram um suporte essencial.

Aos meus tios e primos, mais ou menos distantes, que apoiaram este trabalho.

Aos meus avós José (in memoriam) e Antônia, que mesmo à distância sempre se fizeram presentes pelo exemplo e pelo carinho.

À minha avó Neuza, pela companhia sempre acolhedora e cuidadosa. 
Ao meu avô José (in memoriam), a quem dedico este trabalho, por me introduzir ao sabor das narrativas e da mitologia.

À minha irmã, Amanda, pelo senso de humor e companheirismo nas melhores horas.

À minha mãe, Vania, e ao meu pai, Aguinaldo, pela paciência, apoio e confiança sem limites. Agradeço não apenas pelo investimento emocional e material, mas principalmente pelo exemplo de dedicação ao trabalho e às letras.

À Vanessa, pelo amor e por ter sido, ao longo destes três anos, um porto seguro. Sua sensível presença foi essencial para a superação de inúmeros momentos de incerteza e angústia. Mais que este trabalho, destino-lhe minha admiração e meu amor. 


\section{RESUMO}

DOMICIANO, J. F. G. M. S. (2014) O mito e sua estrutura: contribuições da antropologia lévi-straussiana para a formalização da clínica psicanalítica. Dissertação de Mestrado, Instituto de Psicologia, Universidade de São Paulo, São Paulo

Inserida no intercâmbio teórico entre a psicanálise e a antropologia estrutural, a presente pesquisa busca analisar os papéis e implicações da noção de mito para a constituição de um projeto de formalização da experiência psicanalítica. Em pesquisa anterior, constatamos como na conferência $O$ mito individual do neurótico (1953), Jacques Lacan realizou a aplicação do modelo lógico através da qual o antropólogo Claude Lévi-Strauss tratou da estrutura mítica - a "fórmula canônica do mito" (1955) ao caso freudiano do Homem dos Ratos. Desta premissa, uma questão se impôs: em que medida o modelo da estrutura inerente ao fenômeno mítico foi condição necessária para a apropriação lacaniana do ideário estrutural e quais os efeitos de tal momento constitutivo sobre seu futuro projeto de formalização da clínica psicanalítica. Com tal objetivo em vista, mapeamos inicialmente na obra de Freud as dimensões do tema do mito. Vimos como sua aparição é contemporânea à emergência da psicanálise como uma prática clínica, e como está ligado a um programa antropológico de universalização das descobertas psicanalíticas, cuja maior expressão é a publicação de Totem e Tabu (1912-13) e sua ampliação do valor metodológico da lógica mítica para a apreensão da origem da cultura. A partir de uma revisão das leituras e críticas à psicanálise pelas principais vertentes da antropologia no início do século XX, observamos como o valor epistêmico-metodológico da obra freudiana apenas será plenamente reconhecido com o advento do projeto estrutural de antropologia engendrado por Lévi-Strauss e responsável por inscrever o mito como objeto privilegiado de estudo. Acompanhamos os principais movimentos de Lévi-Strauss pela análise mítica $(1949 ; 1955 ; 1964 ; 1985)$, ressaltando o papel central do modelo da fórmula canônica do mito. A análise das derivações matemáticas de seus termos fundamentais levou-nos a reconhecer seu valor para a psicanálise lacaniana. Neste modelo, Lacan encontrará (a) uma noção de estrutura que assimila a dimensão da dialética e do impossível em seus termos, (b) a base de sua teoria do significante, (c) um meta-modelo de formalização que o acompanhará por toda 
sua obra. A partir desta revisão analisaremos se os desvios conceituais da assimilação lacaniana do modelo de Lévi-Strauss, poderiam retroativamente contribuir para uma revisão do valor da análise mitológica para além dos limites psicanalíticos. Para tal, nos valeremos de uma releitura das análises estruturais do mito de Édipo e do Homem dos Ratos. Cientes dos limites de nosso recorte, indicamos ao fim possíveis desdobramentos deste percurso para pesquisas futuras.

Palavras-chave: Psicanálise; Antropologia; Mito; Estrutura; Clínica . 


\begin{abstract}
DOMICIANO, J. F. G. M. S. (2014) The myth and its structure: contributions of lévi-straussian anthropology to the formalization of psychoanalytical clinics, Master's Dissertation, Institute of Psychology, University of Sao Paulo, Sao Paulo.
\end{abstract}

Situated in the theoretical debate between psychoanalysis and structural anthropology, this research aims to analyse the roles and implications of the concept of myth for the establishment of formalization's project of psychoanalytical experience. In previous research, we found that in the conference The neurotic 's individual myth (1953), Jacques Lacan applied the logical model by which the anthropologist Claude Lévi-Strauss read the mythic structure - the "canonical formula of myth" (1955) - to revised the Freudian case of the Rat Man. From this premise, a question remained: to what extent the model of the structure inherent of the mythical phenomenon was necessary for the appropriation of Lacanian ideas structural condition and what the effects of such constitutive moment on his future formalizations of the psychoanalytic practice. With this aim in view, we initially mapped in Freud's work the dimensions of the theme of the myth. We saw how its appearance is contemporary to the emergence of psychoanalysis as a clinical practice, and how it is connected to an anthropological program of universalization of the psychoanalytic discoveries, whose highest expression is the publication of Totem and Taboo (1912-13) and its expansion of the methodological value the mythical logic to apprehend the origin of culture. From a review of the readings and critiques of psychoanalysis by the anthropologists in the early twentieth century, we saw how the epistemic and methodological value of Freud's work will be fully recognized with the advent of structural anthropology introduced by Lévi-Strauss, and responsible for signing the myth as a privileged object of study. We followed the Lévi-Strauss's main movements in mythical analysis $(1949,1955,1964$, 1985), highlighting the central role of canonical formula of myth. The analysis of the mathematical derivations of its fundamental terms led us to recognize its value to Lacanian psychoanalysis. In this model, Lacan find (a) a type of structure that assimilates the dimension of the dialectic and the theme of impossible in its terms, (b) the basis of his theory of the signifier, (c) a meta-model for formalizing remains 
throughout his work. From this review we analyse if the conceptual deviations of Lacanian assimilation of Lévi-Strauss model, could retroactively contribute to a revision of the value of the mythological analysis beyond the psychoanalytic limits. To this goal, we reread the structural analysis of the myth of Oedipus and the Rat Man. Aware of the limits of this research, we indicate possible outcomes at the end for future studies.

Keywords: Psychoanalysis; Anthropology; Myth; Structure; Clinics. 


\section{SUMÁRIO}

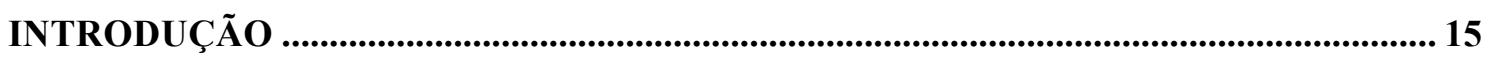

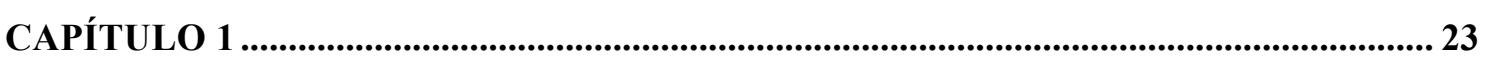

1. O LUGAR DA ANTROPOLOGIA NOS PRIMÓRDIOS DA PRÁTICA CLÍNICA FREUDIANA ... 24

1.1. Formação de uma base semiológica: o caso da histeria .......................... 24

1.2. Práticas terapêuticas distantes espaço-temporalmente e o estatuto da

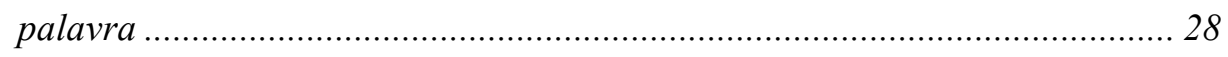

1.3. O destino dos dois recursos à antropologia na obra de Freud ............... 32

2. INSERÇÃO E INFLUÊNCIA DA LÓGICA MÍTICA NA CONSTITUIÇÃO DA CLÍNICA

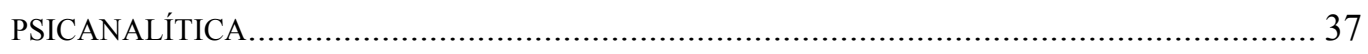

2.1. Édipo e a primeira versão de uma teoria do mito .................................. 42

2.2. Entre Devaneios, Romances e Teorias: incidências da lógica mítica ..... 44

3. DOIS EIXOS DO MITO EM FREUD: SEMIOLOGIA E TRANSFERÊNCIA .............................. 53

CAPÍTULO 2 62

1. A TORÇÃO DA RELAÇ̃̃o DE FREUd COM A ANTROPOLOGIA: TOTEM E TABU E A BUSCA

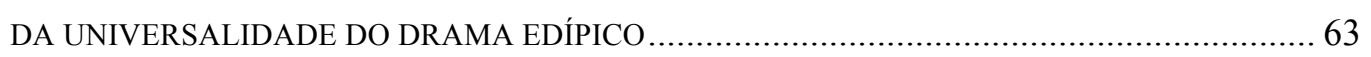

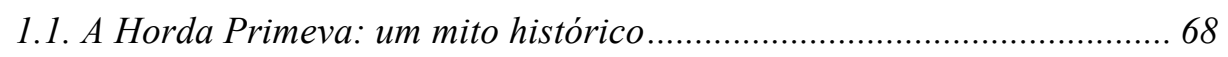

2. AS CRÍTICAS A TOTEM E TABU E AS ESFERAS DE APROXIMAÇÃO ENTRE PSICANÁLISE E ANTROPOLOGIA NO COMEÇO DO SÉCULO XX.............................................................. 72

2.1 Malinowski e a querela da universalidade do Édipo: questões de método 74

2.2. Boas e a introdução da dimensão inconsciente dos fenômenos sociais .. 82

2.3. Rivers e o valor da diagnóstica psicanalítica para a etnologia .............. 90

2.4. Mauss e a eficácia do símbolo: o fato social total.................................. 97

3. LÉVI-STRAUSS E A REVISÃO DO ESTATUTO EPISTÊMICO DE TOTEM E TABU: O MITO E

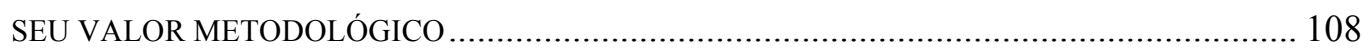

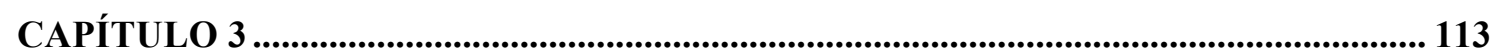

1. LÉVI-STRAUSS E O PROJETO DE UMA ANTROPOLOGIA ESTRUTURAL ………............. 114

1.1. A dupla via de inserção da psicanálise na obra lévi-straussiana.......... 117

2. A EFICÁCIA SIMBÓLICA E SEUS DESDOBRAMENTOS A UMA TEORIA DO MITO ............. 119

2.1. As origens lógico-históricas do escrito ................................................. 119

2.2. O relato de cura e seus elementos narrativos....................................... 121 
2.3. O mito n'A eficácia simbólica: função e associação com o rito. 126

2.4. O rito e sua lógica transformativa .............................................. 128

2.5. O legado da primeira incursão sobre a temática do mito .................... 131

3. O PÉRIPLO ESTRUTURAL DE LÉVI-STRAUSS: DOS MODELOS DE FORMALIZAÇÃO DO

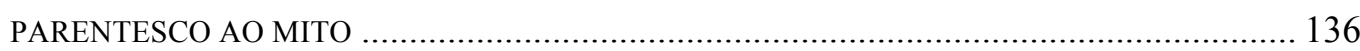

3.1. A categoria de mito e os princípios de sua leitura estrutural............... 140

3.2. O mito de Édipo e a primeira aplicação do método estrutural ............. 147

3.3. O modelo paradigmático da fórmula canônica do mito ....................... 152

3.4. Os desvios interpretativos da fórmula canônica no debate antropológico 158

3.5. A dupla torção e suas implicações estruturais .................................. 164

4. A EXPANSÃO DA ANÁLISE MITOLÓGICA E SUAS DERIVAS METODOLÓGICAS ........... 170

4.1. A questão da língua e a crítica ao formalismo da análise mitológica... 177

5. O MITO DE ÉDIPO E SUAS DERIVAS AMERÍNDIAS: UMA RELEITURA CRÍTICA ............ 181

\section{CAPÍTULO 4}

1. A PSICANÁLISE DE LACAN E A INFLUÊNCIA DE LÉVI-STRAUSS EM SEU PROJETO DE “RETORNO A FREUD” 196

2. O MITO INDIVIDUAL DO NEURÓTICO: A CATEGORIA DE MITO COMO PORTA DE ENTRADA

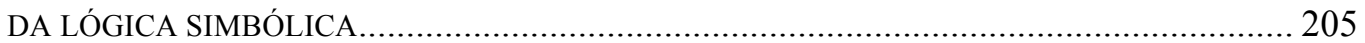

2.1. Entre um sujeito prescindido e um sujeito pré-cindido 207

2.2. O mito individual entre o simbólico, o imaginário e o real: eixos de leitura a uma teoria do mito em Lacan ................................................... 209

3. A NOÇÃO DE MITO E SEUS DESTINOS NA OBRA LACANIANA.................................... 215

3.1. O mito como expressão de uma verdade. 216

3.2. A estrutura dos mitos como projeto global de formalização: da lógica do mitema ao significante lacaniano 224

3.3. A fórmula canônica do mito e sua estrutura quaternária. 229

3.4. A fórmula canônica do mito como meta-modelo de formalização ........ 233

3.5. A dupla torção e sua função de enodamento da estrutura mítica.......... 239

3.6. A psicanálise e seus mitos: a relativização da universalidade de Édipo 242 4. O QUARTO ELEMENTO E SEU ESTATUTO DE SIGNIFICANTE ESPECIAL: NOME-DO-PAI, FALO E S(A) 245

4.1. Inflexões da temática do impossível sobre a ordem do real: o objeto a 253

5. O GOZO COMO MEDIDA DE DISTINÇÃO ENTRE ÉDIPO E TOTEM E TABU..... 256

6. LALANGUE E A POSSIBILIDADE DE RELEITURA DA FÓRMULA CANÔNICA DO MITO ... 259 
7. O CASO DO HOMEM DOS RATOS RELIDO A PARTIR DA ESTRUTURA QUATERNÁRIA DOS MITOS 261

CONCLUSÃO

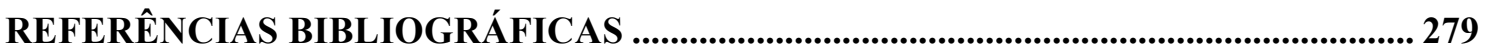




\section{INTRODUÇÃO}

De 2008 a 2010, realizamos uma pesquisa de Iniciação Científica intitulada "Mito e estrutura entre Lacan e Lévi-Strauss", na qual teve lugar uma investigação sobre o modo pelo qual o psicanalista Jacques Lacan assimilou ao projeto epistemológico estrutural, tal como fundido e infundido pelo antropólogo francês Claude Lévi-Strauss (VIVEIROS DE CASTRO, 2008), assim como suas condições de possibilidade e potenciais implicações para a clínica psicanalítica. Demonstramos como na conferência O mito individual do neurótico (LACAN, 1953a) - "seu escrito de maior inspiração lévi-straussiana" (ZAFIROPOULOS, 2001, p.197) e "um dos momentos originários da assimilação do ideário estrutural" (SIMANKE, 2002, p.316) - Lacan realizou a aplicação da fórmula através da qual Lévi-Strauss tratou da estrutura mítica, a "fórmula canônica do mito", ao caso freudiano do Homem dos Ratos (FREUD, 1909). Esta fórmula foi, ao nosso entender e de outros comentadores (DOUVILLE, 2008), uma das noções através das quais tomou formas mais concretas o intercâmbio teórico entre a antropologia estrutural e a psicanálise. Deste modo, buscamos explicitar a especificidade e as condições de possibilidade de tal importação conceitual, destacando tanto sua funcionalidade quanto as modificações derivadas da "peculiar posição lacaniana na sustentação da irredutibilidade da categoria de sujeito" (SAFATLE, 2004, p.30).

Neste momento inicial, o principal intuito era o de retraçar os eixos fundamentais da inserção da fórmula canônica na episteme semiológica psicanalítica, de modo a situar seus termos no interior da análise lacaniana. Diversas questões emergiram ao longo da pesquisa, dentre as quais destaco três: (1) em que medida a lógica inerente ao fenômeno do mito contribuiu para o projeto lacaniano de retomar a obra de freudiana no começo da década de 50, o denominado retorno a Freud; (2) Qual a relevância da assimilação inicial de uma referência estrutural ter sido realizada a partir de uma obra proveniente da antropologia, em particular, a de Lévi-Strauss; (3) e, por fim, teriam os termos da importação lacaniana da fórmula de transformação mítica contribuído para seu uso para além dos limites da psicanálise, possibilitando diferentes leituras no interior das análises antropológicas. A produção destas questões foram centrais para a construção do presente projeto. Podemos dizer, de maneira sucinta, que nosso objetivo primário é o de demonstrar como a temática do mito não apenas marcou um campo 
privilegiado de trocas entre a psicanálise e a antropologia, como contribuiu decisivamente para o projeto de formalização psicanalítica, seja por seu intrínseco valor antropológico, seja pelos modelos matemáticos a ele associado. Para introduzirmos e complexificarmos nossa questão, começaremos por remeter-nos às formas e modulações assumidas pela lógica do mito na interlocução entre psicanálise e antropologia.

Decerto, causa espécie a um leitor não ambientado no tema, o papel proeminente da noção de mito em uma pesquisa acadêmica. Sabemos como o mito é amplamente representado na sociedade ocidental como uma narrativa fantasiosa de menor valor, um relato de deuses e heróis acerca das origens ou fins dos tempos, que não segue nenhuma lógica ou rigor científico que lhe confira, ao menos, um estatuto de verossimilhança com fatos passados. Entretanto, tal leitura não é exclusividade da sabedoria popular, ela esteve presente entre estudiosos das ciências sociais até a metade do século XX, neste contexto, resume Lévi-Strauss: "Como quer que se encarem os mitos, eles parecem se reduzir todos a um jogo gratuito, ou a uma forma grosseira de especulação filosófica” (LÉVI-STRAUSS, 1955, p.222).

Proveniente do grego, o termo muthos, denota uma das facetas da ideia de "palavra". Não é a palavra como logos, discurso científico, que se articula como um saber logicamente construído, um discurso que sustente uma verdade; nem a palavra como epos, que se institui como uma narrativa indireta acerca da origem histórica de uma pessoa, comunidade ou grupo (DUNKER, 2008, p.3). O mito, configura-se como a palavra posta em ato, em discurso. Mas, diferentemente das outras duas modulações da "palavra", o mito impõe-se como uma narrativa de tempos imemoriais, uma narrativa contada antes ou depois que qualquer pessoa pudesse testemunhar, e que, por sua vez, responde por um evento que ressoa na estrutura presente e permanente do mundo, seja um fato natural, seja um dado no âmbito da cultura. Entretanto, o mito apresenta uma interessante característica que o distingue de qualquer narrativa fortuita, como podemos ver no seguinte comentário de Lévi-Strauss:

É melhor reconhecermos que o estudo dos mitos nos leva a constatações contraditórias. Tudo pode acontecer num mito. A sucessão dos eventos não parece estar aí submetida a nenhuma regra de lógica ou de continuidade, qualquer sujeito pode possuir qualquer predicado, qualquer relação concebível é 
possível. Contudo, os mitos, aparentemente arbitrários, se reproduzem com as mesmas características e, muitas vezes, os mesmos detalhes, em diversas regiões do mundo. Daí a questão: se o conteúdo do mito é inteiramente contingente, como explicar que, de um extremo a outro da terra, os mitos se pareçam tanto? (LÉVI-STRAUSS, 1955, p.224)

O mito, portanto, portaria essa faceta de ser uma narrativa a um só tempo ligada à historicidade de seu recitar - cujo registro próprio é o da fala - e de impor regras estruturais que lhe confere a semelhança temática e de enredo independentemente daqueles que os recitam - cujo registro é o sistema lógico linguagem. A recorrência para além dos limites históricos ou geográficos é um dos principais fatores que candidatam um fato cultural a ser reconhecido em sua extensão antropológica, e toda aspiração universalisante que esta categoria carrega. A possibilidade de extrair leis e regras do conjunto de narrativas míticas tem grande importância para a leitura em termos de estrutura dos fenômenos etnológicos, pois, como nos diz o antropólogo francês: "se o espírito humano se mostra determinado até mesmo em seus mitos, então $a$ fortiori deve sê-lo em toda parte" (LÉVI-STRAUSS, 1964, p.30).

Eis onde se insere o projeto estrutural de análise dos mitos tal qual proposto por Lévi-Strauss. Como será analisado em detalhes, no início dos anos 50, Lévi-Strauss deriva do método engendrado pela linguística estrutural um modelo de apreensão da lógica mítica que não apenas reinscreve, no cerne de sua disciplina, o mito no rol de fenômenos passíveis de uma análise racional, como o torna o objeto privilegiado em sua obra por pelo menos trinta anos. Entretanto, um estudioso da psicanálise não se surpreende ao constatar a articulação entre a temática do mito e um projeto de extração de uma universalidade inerente a sua lógica, posto que este já encontrava ressonâncias nos primórdios da obra freudiana.

Desde seus primeiros passos na clínica psicopatológica, ainda muito influenciado pelo ensino do psiquiatra francês Jean-Martin Charcot, Freud concebe o lugar fundamental da antropologia para uma crítica dos pilares da racionalidade clínica psiquiátrica hegemônica de então. Ele recorre a fatos históricos e etnográficos para inscrever nas bases de leitura dos fenômenos clínicos o poder da palavra e de sua eficácia - de modo a sustentar a posição legítima da histeria como um quadro 
diagnóstico e a terapêutica pautada na palavra dela indissociável (FREUD, 1890). Poucos anos depois, concomitante à emergência da psicanálise como uma prática clínica, Freud articula a lógica do mito, aqui lido a partir da lenda de Édipo, ao potencial de generalização necessário a uma teoria acerca do psiquismo, portanto, à edificação de uma metapsicologia. O lugar central do mito na experiência analítica é salientado por Lacan no seguinte comentário:

Não nos é possível abordar o tema com que lidamos na análise sem encontrar a função do mito. Isso é um fato comprovado pela experiência. Em todos os casos, desde os primeiros passos da análise, a Traumdeutung, Freud se apoia em uma referência ao mito, e em especial ao mito do Édipo. Isso é elidido por nós, colocamo-lo entre parênteses, tentamos exprimir tudo de nossa experiência sob o modo econômico, como se diz por exemplo a função do conflito entre tendências primordiais, até as mais radicais, as defesas contra as pulsões, a articulação, conotada topicamente na tese sobre o narcisismo, do ego e do ego ideal, e depois um certo isso. Ir neste sentido, perder a outra borda de referência, deve se apreciar em nossa experiência como um esquecimento, no sentido positivo que o termo tem para nós. Isso não impede a experiência, que continua a ser sempre uma experiência analítica. Mas é uma experiência analítica que esquece seus próprios termos (LACAN, S.VIII, p.311).

O mito, por esta via, é conceituado como um fato que não deve ser elidido da experiência analítica. Ele expressa não somente a possibilidade de dar tratamento simbólico a temas e conflitos impossíveis de serem tratados de outra maneira, como também aponta para um princípio de sistematização que permitiria a uma ciência do sujeito habitado pela linguagem articular formalmente seus termos. Em outras palavras, no interior da teoria psicanalítica o mito circunscreveria a ligação intrínseca entre uma dinâmica histórica - pautada por conflitos, tensões, acumulações de experiências e vivências - e uma lógica antropológica - regida pelas leis fundamentais do significante, cujo princípio estrutural dota-a de valor universal. Nas palavras de Lacan: 
Este é um jogo no qual se trata de detectar as regras que lhe dão rigor. E reparem que não há outro rigor concebível além daquele que se instaura justamente no jogo. $\mathrm{Na}$ função do mito, em seu jogo, as transformações se operam segundo certas regras, que por esse motivo tem um valor revelador, criador de configurações superiores ou de casos particulares iluminadores. Em suma, demonstram a mesma espécie de fecundidade que as matemáticas. É disso que se trata na elucidação dos mitos. (LACAN, S.VIII, p.310)

Portanto, o mito encontra-se como uma via privilegiada na tentativa de se formar um campo conceitual da prática psicanalítica. Como teremos oportunidade de analisar em detalhes, é justamente por confiar na capacidade mítica de articular o universal ao particular, que Freud realizará sua obra mais ousada, a saber, Totem e Tabu (1913). Neste escrito, o psicanalista convoca grandes nomes da antropologia de sua época para contribuir com a formulação de uma hipótese acerca da origem da cultura e das instituições sociais. Tal hipótese - que não apenas marca a tentativa de uma contribuição psicanalítica às ciências sociais, como realiza a própria inscrição das descobertas freudianas sobre a universalidade da ordem humana - reencontra a dupla dimensão antropológica e histórica: Freud propõe aí um "mito científico", um mito inscrito nos limites da história, a qual Freud busca a um só tempo assegurar a dimensão de um ato inaugural e da efetividade simbólica que perpetuaria seus efeitos (FREUD, 1913, p.190).

Neste contexto, Lévi-Strauss aparece como uma figura central para a leitura do fenômeno mítico. Ele não apenas subverterá a chave de leitura do clássico freudiano no interior do campo da antropologia ao considerar seu valor de mito, como introduzirá um modelo de formalização da estrutura mítica, que levará Lacan a operar um reposicionamento global de sua leitura da teoria e da clínica psicanalítica. A reestrutura da obra lacaniana propiciada pelo "contato com a experiência etnológica" (LACAN, 1953b, p.241), tem o mito, portanto, como um de seus pontos basais. Nos termos de Zafiropoulos:

O sentido do "retorno à Freud" é o de reintroduzir o mito no coração da experiência psicanalítica. O mito de Édipo, 
mas também e mais globalmente todo o que o psicanalista empresta da antropologia francesa especialmente de LéviStrauss, e reside na ordem simbólica que Lacan, como LéviStrauss, reserva ao princípio de estruturação das sociedades como ao princípio de estruturação do inconsciente. (ZAFIROPOULOS, 2004, p.19-20)

Deste período inaugural a uma referência estruturalista como forma (LACAN, 1966, p.76), localizado no inicio dos anos 50, tanto a obra de Lévi-Strauss como a de Lacan, trilharam caminhos que impõem uma revisão do potencial diálogo entre as duas disciplinas, em especial no que concerne à temática do mito. Eis a via em que nos inserimos no presente trabalho. Como veremos em detalhes, se Lévi-Strauss direciona sua obra, no que diz respeito ao tema do mito, tanto para o desenvolvimento de modulações dos métodos de apreensão da estrutura mítica (LÉVI-STRAUSS, 1964, 1967, 1971, 1985), como para a expansão de seu modelo fundamental de transformação para fatos de outras espécies (LÉVI-STRAUSS, 1956, 1973, 2001), Lacan apresentará, nos destinos do conceito, um grande movimento que, ao mesmo tempo em que resguarda o valor lógico do sistema significante, explicita as múltiplas derivações e modalidades do tema do impossível no interior do regime discursivo do mito (LACAN, 1953a, S.IV, S.VIII, S.XVII). Aqui retomamos a questão: ao fazermos esses caminhos novamente se cruzarem, em que termos poderíamos retomar a análise e estrutura dos mitos? Haveria neste percurso uma via de mão dupla que nos permita, uma vez mais, esclarecer pontos obscuros a ambas as disciplinas (LÉVI-STRAUSS, 1949, p. 218)?

Feita esta breve introdução, faço uma apresentação esquemática dos temas tratados em cada capítulo desta dissertação. No capítulo inicial, apresentaremos os primeiros recursos freudianos às ciências sociais, enfatizando o lugar da disciplina antropológica para a fundamentação de uma concepção de clínica que compreenda a palavra em sua eficácia de determinação sintomática e, consequentemente, de tratamento. Extraído os termos deste primeiro momento, partiremos para as incidências da noção de mito, em especial o de Édipo, na teoria freudiana, assim como seu valor para a leitura da experiência clínica psicanalítica. Neste contexto, deparamo-nos com a construção de uma obra como Totem e Tabu, que a um só tempo, expressa o grau máximo do contato de Freud com os teóricos das ciências sociais, e amplia o valor metodológico da lógica mítica para a apreensão científica da origem da cultura. 
No segundo capítulo, apresentamos a inscrição de Totem e Tabu no contexto da antropologia do início de século $\mathrm{XX}$, assim como as primeiras recepções às suas hipóteses. Para além das críticas às referências etnológicas empregadas por Freud, veremos aqui uma crítica ao próprio valor do mito como objeto digno de atenção de uma análise antropológica. Teremos oportunidade de observar como nas particularidades da interlocução de quatro dos maiores expoentes da disciplina Malinowski, Boas, Rivers e Mauss - com a psicanálise freudiana, a relação entre estrutura e história assume um papel prevalente, decisivo para as modulações da aproximação ou distanciamento da teoria psicanalítica. Neste solo que emergirá um antropólogo como Lévi-Strauss, que não apenas reconhecerá o valor epistêmico e metodológico do fenômeno mítico, como reposicionará o diálogo com Totem e Tabu e com toda a produção psicanalítica.

O terceiro capítulo é especialmente dedicado para a análise dos destinos e leituras do mito na obra de Lévi-Strauss. Encontraremos aí a sustentação do mito como elemento central de suas análises estruturais, passando primeiramente como articulador da eficácia simbólica em um contexto terapêutico, para em seguida ter sua estrutura matemática estabelecida - a fórmula canônica do mito - e, por fim, sua sistematicidade significante ampliada para uma forma de coordenação e assimilação global do espírito o pensamento selvagem, também denominado pensamento mito-poético. Além de analisar em detalhes os modelos de apreensão da fórmula canônica, veremos sua funcionalidade para a extração lógica dos termos fundamentais do mito de Édipo. Através de uma revisão crítica de sua compreensão da trama edípica, assinalaremos possíveis caminho de retomada de seus termos a partir da contribuição da teoria psicanalítica.

Por fim, no quarto e último capítulo tomaremos como mote central a incidência do mito e de sua estrutura na obra de Lacan. Veremos como a noção de mito, importada diretamente da antropologia de Lévi-Strauss, será central desde o momento inaugural de sua assimilação de um pensamento estrutural, mais precisamente na conferência $O$ mito individual do neurótico. Teremos oportunidade de observar não apenas como o interesse pelo mito responde à releitura da neurose no pensamento lacaniano, como estabelece, a partir do modelo da fórmula canônica de Lévi-Strauss, um princípio de estrutura que ressoará em todo projeto lacaniano de formalização da experiência analítica - desde seu valor metodológico para a apreensão da noção de significante, até 
a construção futura de seus grafos, modelos e esquemas. A partir deste ponto, explanaremos os meios pelos quais a fórmula lévi-straussiana pode ser retomada na teorização lacaniana, assim como as contribuições do pensamento do psicanalista francês para se pensar as faces do impossível impresso na leitura de Lévi-Strauss. Por fim, retomaremos sua leitura do caso do Homem dos Ratos, para demonstrar o valor de sua retomada para a compreensão e funcionalidade da análise mítica.

Esperamos, ao cabo deste percurso, ter ao menos produzido uma pesquisa que reconsidere e faça um balanço crítico do papel crucial da temática do mito - em sua inerente interlocução com a disciplina antropológica - para a apreensão da experiência psicanalítica. Enfim, que retomemos suas condições estruturantes sem "esquecer seus termos". 


\section{CAPÍTULO 1}

A publicação dos quatro ensaios de Totem e Tabu, entre 1912 e 1913, não somente marcou a mais significativa tentativa de Freud de se aproximar daqueles que se dedicavam "à antropologia social, à filologia e ao folclore" (FREUD, 1913, p.17), como representou, principalmente, uma profunda modificação no estatuto dado ao conjunto das ciências sociais para a edificação da teoria psicanalítica. Doravante, bem mais que uma fonte de exemplos e ilustrações para postulados extraídos de um ambiente eminentemente clínico, os avanços realizados pelos primeiros deveriam ser tomados como meios a partir dos quais a psicanálise seria convocada a propor modelos explicativos e a colocar à prova seus próprios modelos. A assunção de uma troca generalizada entre disciplinas não endogâmicas a um só tempo funda e é fundada pelo princípio, ou desejo, de apreensão de uma estrutura psíquica universal, válida para todos os homens.

A questão da origem da cultura e de suas instituições fundamentais tem, nesta via, uma posição de destaque nos debates travados entre as duas disciplinas a partir dos anos 1930, entretanto, não podemos dizer que o mesmo se deu com relação à dimensão terapêutica tanto das considerações psicanalíticas, quanto dos dados coletados em campo e analisados pela antropologia. Não são poucos os fatores confluíram para a constituição de tal cenário - em que pese não apenas o momento da antropologia no início do século XX, como a incipiente produção na área da antropologia da doença mas é certo que eles deixaram uma profunda marca, do lado dos antropólogos, na própria possibilidade de se vislumbrar no arsenal teórico e metodológico psicanalítico um ambiente propício para ao debate sobre os fundamentos da cultura. No entanto, este não é o começo do contato entre as duas disciplinas.

O objetivo deste capítulo é apresentar os primórdios das remissões e usos do referencial teórico antropológico no interior da obra freudiana, de modo a delimitar a particularidade da inscrição da temática do mito na economia conceitual psicanalítica, tal qual proposta por Freud. Começaremos analisando o primeira papel que tomou aí a antropologia e as ciências sociais, a saber, o de responder por um conjunto de caracterizações patológicas de tempos e sociedades distintas e suas práticas de cura cuja função seria dar lastro à fundamentação de uma racionalidade clínica distinta da 
hegemônica na época. Neste percurso, evidenciaremos a maneira pela qual Freud articula o papel da palavra e da narrativa, em sua eficácia e função, que serão de suma importância para a emergência da psicanálise enquanto uma prática sui generis. Por fim, passaremos à reconstrução do inscrição da noção de mito na obra freudiana, contemporânea à própria psicanálise, de modo a apresenta-la tanto em sua crescente inserção no conjunto da teoria, enquanto um recurso metodológico essencial para sua edificação, como nas múltiplas facetas que este assimila ao longo de seu uso por Freud. Tomemos a sério as palavras do Rei de Copas e comecemos do começo nosso percurso.

\section{O lugar da antropologia nos primórdios da prática clínica freudiana}

Mais de vinte anos antes da publicação de Totem e Tabu, portanto bem antes da invenção da psicanálise, vemos as primeiras menções de Freud a fenômenos retirados de investigações históricas e sociais (FREUD, 1886, 1888, 1890). Destaca-se aí um claro interesse pelas descrições patológicas e tratamentos presentes na antiguidade, na idade média e em povos culturalmente distantes. Neste momento de sua obra, o recurso freudiano a tais formas de vida pode ser repartido, para fins de análise, em dois papéis: o primeiro seria o de justificar a pertinência do quadro nosográfico da histeria no interior de uma psicopatologia científica; o segundo estaria relacionado à identificação e superação das possibilidades terapêuticas encontradas então para lidar com quadros histéricos e de patologias psíquicas afins.

\subsection{Formação de uma base semiológica: o caso da histeria}

Desde o Relatório sobre meus estudos em Paris e Berlim (FREUD, 1886) encontramos a influência do psiquiatra francês Jean-Martin Charcot e da escola do Salpêtrière no recurso freudiano a documentos históricos (FREUD, 1888; ELLENBERGER, 1970) que ancorassem sua descrição dos sintomas e quadros patológicos histéricos na amplitude da história da civilização, mais especificamente na fenomenologia da feitiçaria, da possessão e de agenciamentos afins. Um dos objetivos de Charcot era o de afastar a descrição global do quadro da histeria de uma representação que a identificasse como mera simulação, dramatização ou exagero (Cf. 
FREUD, 1888), cujas consequências podem ser notadas na seguinte passagem do relatório de Freud:

Durante as últimas décadas, é quase certo que uma mulher histérica seria tratada como simuladora, do mesmo modo que, em séculos anteriores, certamente seria julgada e condenada como feiticeira ou possuída pelo demônio. Sob outro aspecto, é possível que até se tenha dado um passo atrás no conhecimento da histeria. A Idade Média estava familiarizada de modo preciso com os "estigmas" da histeria, seus sinais somáticos, e os interpretava e utilizava à sua própria maneira. No departamento de ambulatório, em Berlim, contudo, verifiquei que esses sinais somáticos da histeria eram praticamente desconhecidos e que, em geral, quando se fazia um diagnóstico de "histeria", parecia estar eliminada qualquer motivação para se obter mais algum informe a respeito do paciente. (FREUD, 1886, p.42)

Como Freud irá tratar mais tarde, as descobertas e avanços realizados pela medicina do século XIX, aquela na qual estava inserido, acerca dos determinantes físicos nos processos patológicos fizeram com que muitos de seus pares restringissem "seu interesse ao corporal e de bom grado deixaram aos filósofos, a quem menosprezavam, a tarefa de se ocuparem do anímico" (FREUD, 1890, p.294), assim como seu papel causal em diversos fenômenos incompatíveis com a clínica organopatológica, como a histeria. Demonstrar que o quadro sintomatológico histérico - ou seja, o conjunto de seus sinais somáticos - tinha recorrências descritivas tanto no interior da história, quanto em culturas e espaços distintos, era uma forma de legitimar a necessidade de uma investigação científica com vistas a identificar suas particularidades fenomênicas, sintomáticas, assim como sua etiologia e possível tratamento.

O estabelecimento ou assimilação de uma semiologia, marca um passo decisivo para todo fazer clínico. Por semiologia, podemos definir um conjunto de operações de leitura, portanto, de classificação e ordenação sinais, traços, sintomas, etc. de modo a discriminá-los e dotá-los de um valor diferencial (Cf. DUNKER, 2001, p.41), ou seja, de articulá-los um sistema que produzirá uma significação patológica ou 
não, essencial para a construção do quadro clínico. Dunker, no contexto da clínica médica clássica, exemplifica tal operação da seguinte forma: "a febre, as alterações na coloração, na textura ou na forma de uma região do corpo são signos que se articulam de forma simultânea ou sucessiva e é esta articulação que deve ser captada pelo olhar clínico" (DUNKER, 2001, p.42).

Ora, toda operação semiológica, constitui-se a partir de uma racionalidade epistemológica própria de cada concepção de clínica, em outros termos, de um modus operandi que revela seus princípios e premissas na produção de um fato clínico. No modelo médico organopatológico, aqui denunciado por Freud como incapaz de produzir uma leitura sobre os sinais somáticos da histeria - que, assim, permaneciam praticamente desconhecidos - o olhar constituía-se como fundador do que poderia ser lido ou não (Cf. FOUCAULT, 1963, p.127). Através do esquema instituído por tal racionalidade, que poderíamos designar como positivista, se um dado fenômeno disfuncional tivesse uma marca visível ao nível da anatomia ou fisiologia que pudesse responder por um substrato etiológico, estaria habilitado a alçar ao estatuto de fato clínico (no caso, patológico) e, consequentemente, seria considerado digno de atenção e cuidados terapêuticos.

A remissão de Freud a outras modalidades semiológicas, sejam recolhidas de dados históricos ou etnográficos, denota a clara consciência, na precoce atividade clínica do então jovem médico vienense, da distinção entre o processo de leitura do fenômeno e a aparição do mesmo - ou, nos dizeres de Charcot, de que "teoria é bom, mas não impede que as coisas existam” (FREUD, 1893, p.23). Mais ainda: diante de um objeto que demonstra uma desarmonia ou incompatibilidade com um modelo de leitura, o dever de um cientista (no caso, de um médico), não é negar o objeto, mas sim rever as premissas de sua teoria. Este espírito descritivo, herdado de Charcot, está presente a um só tempo no ideal naturalista, cujo grande nome fora Jussieu (CHERTOK; STENGERS, 1989, p.41), quanto no uso daí derivado que o mestre francês faz da história e da etnografia. Este mesmo espírito será decisivo, ao longo de toda a obra freudiana, para a constante desconstrução e retificação de sua teoria.

Entretanto, no momento aqui tratado, o impacto desta abertura à possibilidade de uma semiologia que incluísse a histeria como um quadro nosográfico é tal que Freud chega a estabelecer registros clínicos cuidadosamente detalhados, que mostram quão 
importante era para sua argumentação tais descrições, como se pode notar na passagem abaixo:

As áreas da pele que estão histericamente anestesiadas caracterizam-se, com frequência, por anemia local e não sangram quando picadas [...] Os distúrbios da sensibilidade são os sintomas nos quais é possível basear um diagnóstico de histeria, mesmo nas suas formas mais rudimentares. Na Idade Média, a descoberta de áreas anestésicas e não-hemorrágicas (sigmata Diaboli) era considerada prova de feitiçaria. (FREUD, 1888, p.84)

O projeto de formação de uma base semiológica, nos termos pretendidos por Freud, institui uma problemática que se expressa na seguinte tensão: como estabelecer um princípio descritivo dos fatos psicopatológicos que responda a um só tempo às distintas "interpretações" recebidas pelos fenômenos em contextos heterogêneos, portanto, que assimilem a diferença e particularidade de cada leitura; e que responda ao princípio universal que os unem, que os tornam homólogos. Em outros termos, como buscar uma linguagem para a descrição clínica que sustente e reconheça a universalidade, sem desconsiderar o valor e as particularidades de cada sistema de leitura.

Caracterizada a pertinência da descrição do quadro psicopatológico da histeria, resta a questão de como tratá-la se, tanto os métodos para sua identificação, quanto os aplicados para a possível cura, eram insuficientes à medicina da época? Neste momento, nos primórdios de atividade clínica de Freud e ainda muito influenciado pelo contato com Charcot e Joseph Breuer, inscreve-se a segunda função da remissão freudiana à antropologia e ciências sociais, em especial, às descrições de práticas de tratamento empregados em culturas distantes histórico e geograficamente. 


\subsection{Práticas terapêuticas distantes espaço-temporalmente e o estatuto da palavra}

Um texto representativo deste momento é Tratamento psíquico, tratamento da alma ${ }^{1}$, de 1890, no qual, ao retratar a possível etiologia anímica de patologias físicas, corporais, Freud propõe e analisa estratégias de tratamento não previstas pelos manuais médicos de então. A palavra e seu estatuto eficaz têm um papel privilegiado na argumentação deste texto que é, curiosamente, aquele que entendemos ter mais pontos de convergência têm com o canônico A eficácia simbólica (LÉVI-STRAUSS, 1949b), essencial para o presente projeto e que veremos à frente. O poder mágico das palavras, tal qual entendido e instrumentalizado por povos de outras culturas e épocas, é considerado por Freud como um fato que convoca o saber científico da clínica psicoterapêutica a tomá-lo como objeto de estudo e a retirar daí benefícios para a técnica de tratamento psicopatológico, em suas palavras:

Um desses meios [de influir em perturbações anímicas ou físicas] é sobretudo a palavra, e as palavras são também a ferramenta essencial do tratamento anímico. O leigo por certo achará difícil compreender que as perturbações patológicas do corpo e da alma possam ser eliminadas através de "meras" palavras. Achará que lhe estão pedindo para acreditar em bruxarias. E não estará tão errado assim: as palavras de nossa fala cotidiana não passam de magia mais atenuada. Mas será preciso tomarmos um caminho indireto para tornar compreensível o modo como a ciência é empregada para restituir às palavras pelo menos parte de seu antigo poder mágico. (FREUD, 1890, p.297)

O tratamento anímico, assim como o futuramente denominado tratamento psicanalítico, tem como principal meio a palavra, ou melhor, a fala e sua eficácia inerente. No entanto, o uso da fala ainda está, neste momento inicial da obra freudiana,

\footnotetext{
${ }^{1}$ No original alemão Psychische Behandlung (Seelenbehandlung) Ao utilizar o termo Seele, Freud não traz a conotação mística-religiosa do termo. Ele joga, por outro lado, com a polissemia de Seele traduzível por "espírito", "alma", "psique" ou "mente" (Cf. HANNS, 1996). Tal indeterminação é correlata dos empregos no referido escrito.
} 
restrito a um contexto sugestivo, ou seja, o poder da fala do médico que teria a capacidade de eliminar os sintomas. Outrossim, devemos ressaltar que a proposta de tratamento pela palavra e sua comparação com outras terapêuticas do mesmo gênero são frutos do reconhecimento do caráter ideogênico dos fatores etiológicos envolvidos na doença, levando-se então à consideração por uma forma de intervenção que mantenha uma relação de isonomia com a causa do quadro patológico.

Com vistas a nos situar no debate, deve-se ressaltar que a histeria, sob o projeto de descrição de quadros clínicos gerais de Charcot (BERCHERIE, 1980, p.98), é então compreendida como um conjunto múltiplo composto de sintomas somáticos heteróclitos, ou seja, sem uma convergência fenomênica, que geram graves sofrimentos nos doentes, mas que não estariam relacionados a um substrato orgânico último - falta esta prenhe de consequências para o julgamento social destes enfermos. As perturbações histéricas podem surgir ou desaparecer por uma modificação das condições de vida de uma pessoa, ou ainda podem mudar de lado no corpo, fazendo Freud concluir que os "sinais de padecimento estão muito claramente sob a influência das excitações, comoções, preocupações, etc.” (FREUD, 1890, p.299). Ao se tomar em conta sua origem e natureza, continua Freud, "fez-se então a descoberta de que, pelo menos numa parcela desses enfermos, os sinais da doença não provinham de outra coisa senão uma influência modificada da vida anímica sobre seu corpo, devendo-se, portanto, buscar no anímico a causa imediata da perturbação." (Ibidem, p.300).

A constatação da influência destrutiva do anímico, ou do psíquico, sobre a saúde orgânica - extensamente descrita desde os primeiros relatos antropológicos e analisada por Lévi-Strauss (1949c) através dos escritos do fisiologista Cannon (1942) acerca do maldizer próprio do Voodoo - encontra aqui um paralelo com o escrito de Lévi-Strauss com uma distância de pelo menos sessenta anos: "não há dúvida alguma de que a duração da vida pode ser consideravelmente abreviada pelos afetos depressivos, do mesmo modo que um choque mais violento, uma "injúria" contundente ou uma humilhação podem dar um fim repentino à vida" (FREUD, 1890, p.301). A partir do papel de determinação do anímico nos destinos do homem, Freud parte para a consideração dos princípios da cura, através de exemplos de outras formas terapêuticas, nas quais as curas milagrosas formam o modelo de base. Dentre os principais fatores das curas fantásticas, encontra-se a crença, ou a expectativa do paciente sobre o tratamento que será realizado, como vemos nesta longa cita: 
A expectativa confiante e esperançosa é uma força atuante com que temos de contar, a rigor, em todas as nossas tentativas de tratamento e cura. De outro modo, não poderíamos explicar a peculiaridade dos efeitos observados dos medicamentos e intervenções terapêuticas. Dentre os mais palpáveis está a influência da expectativa confiante nas chamadas curas miraculosas, ainda hoje efetuadas diante de nossos olhos sem a colaboração de nenhuma habilidade médica. As curas milagrosas típicas realizam-se nos crentes sob a influência de cerimônias próprias para intensificar os sentimentos religiosos, ou seja, em lugares onde se adora uma imagem milagrosa, ou onde uma figura santa ou divina revelouse aos homens [...] Não parece fácil à fé religiosa, por si só, suprimir a doença pelo caminho da expectativa, pois, em geral, há ainda o concurso de outras coisas nas curas milagrosas. (FREUD, 1890, p.303)

A posição freudiana é contrária à negação, ou subestimação da eficácia deste tipo de cura. Antes de tratá-la como mero logro ou desprovida de estatuto racional, Freud, mostra-se favorável à legitimação de suas ações curativas. A expectativa confiante na cura, seja formada pela crença intensificada pelo entusiasmo da multidão (Ibidem, p.304), das pessoas que acompanham em coro sua eficácia, seja formada pelo seu substituto no plano individual, ou seja, o prestígio do médico, são essenciais para se balizar a correspondência destes modelos de terapêuticas ditas antigas e as praticadas pelos médicos atuais, em especial aqueles que se valem agora da psicoterapia no tratamento da histeria. Tal homologia apresenta-se neste trecho do texto freudiano:

Os médicos têm praticado o tratamento anímico desde sempre, ainda mais abundantemente em épocas remotas do que hoje em dia. Quando entendemos por tratamento psíquico o esforço de provocar no doente os estados e condições anímicos mais propícios para a cura, vemos que esse tipo de tratamento médico é, historicamente, o mais antigo. Os povos da antiguidade mal dispunham de outra coisa senão o tratamento 
psíquico; e nunca deixavam de apoiar o efeito das poções curativas e das medidas terapêuticas mediante um tratamento anímico insistente. Os conhecidos usos de fórmulas mágicas, banhos purificadores e invocação de sonhos oraculares dormindo no salão do templo, entre outros, só podem ter-se tornado curativos por via psíquica. [...] Assim, tanto naquela época quanto hoje, a pessoa do médico era uma das condições principais para promover no doente o estado psíquico propício a cura. (FREUD, 1890, p.304)

No interior do pensamento freudiano, tais considerações, além de salientar a importância da influência da fala e da vida anímica na determinação de quadros patológicos, tinham como função delimitar a herança legada ao tratamento hipnótico, que no modo como era utilizado então, fazia-se valer por seus efeitos sugestivos na dissolução dos sintomas. A esperança de alçar um novo método para quadros ainda incuráveis, ou melhor, de lançar mão de um "moderno tratamento anímico sistemático, que representa uma revivescência inteiramente nova de antigos métodos terapêuticos, era a de colocar nas mãos dos médicos armas ainda muito mais fortes para lutar contra a doença" (Ibidem, p.316).

O poder mágico das palavras, ou seja, sua influência nos estados físicos e psíquicos dos seres humanos era concebido por Freud como efeito da sugestionabilidade produzida por um estado hipnótico, desde os mais profundos até os mais leves, nos quais a atenção do mundo e a volição do sujeito estão todas centradas na influência do médico, potencializada por esta condição, e como tal, servia de mola do tratamento anímico.

Neste contexto, a busca sistemática pela descoberta dos determinantes próprios a este denominado "moderno tratamento anímico", se por um lado introduz os modelos de tratamento antigos como fonte de inspiração, enquanto de práticas que se valem da função e eficácia do símbolo, por outro, coloca o problema da possibilidade de apreensão científica - ao nível da técnica - da dinâmica de poder e influência que está em jogo em um tratamento. Se temos aí o protótipo do que posteriormente será concebido através dos conceitos de transferência e de resistência, ainda não se encontra estabelecido no pensamento freudiano um modelo de codificação da prática clínica que 
lhe permita inscrever teoricamente (classificar, agrupar, ordenar) e manejar, ao nível do símbolo, os efeitos primários e colaterais de tal influência.

\subsection{O destino dos dois recursos à antropologia na obra de Freud}

Dos dois usos feitos por Freud no início de sua experiência clínica, dos dados coletados por descrições históricas de casos patológicos e suas respectivas modalidades de curas, apenas o primeiro, que diz da ancoragem e recorrência semiológica de fenômenos de tempos e culturas distintos, terá seu estatuto intocado ao longo do resto de sua obra, como se pode notar, apenas para citar as mais relevantes, nas seguintes obras: Atos obsessivos e práticas religiosas (1907); Moral sexual "civilizada” e doença nervosa moderna (1908), Totem e Tabu (1912-3); Uma neurose demonológica do século XVII (1923); O futuro de uma ilusão (1927).

No que diz respeito ao estatuto dos tratamentos realizados em outras culturas para se considerar a terapêutica psicanalítica, podemos dizer que na obra de Freud a valoração e destino destes tratamentos estarão atrelados à temática da hipnose e da sugestão, sendo um assunto pouco tratado a partir do abandono dessa técnica e o advento da prática psicanalítica. No decorrer dos escritos freudianos, é nitidamente marcada a virada na técnica terapêutica propiciada pelo abandono primeiro da sugestão, em prol de um método de tratamento que visasse atingir o conteúdo ideativo que mantinha o quadro patológico; e através do abandono posterior da hipnose, que dará lugar a uma "talking cure", uma terapêutica pela fala liberta do paciente. Tais modificações na prática de tratamento tiveram como consequência imediata um ganho epistemológico, a saber, a possibilidade de se apreender e descrever dimensões desta experiência (recalque, fantasia, sexualidade) que subsistiam camuflados pelas outras técnicas e que representaram o início do que seria a descoberta de um modo de cura original: o método psicanalítico. Para dimensionar o lugar que tomou os tratamentos mágicos na obra freudiana, ou melhor, seu valor, consideremos o seguinte comentário:

Para o médico, ele [o tratamento sugestivo] se tornava, a longo prazo, monótono: em cada caso, proceder da mesma maneira, com o mesmo ritual, proibindo aos mais variegados sintomas existirem, sem ser capaz de aprender nada de seu 
sentido e significado. Era um trabalho braçal, não uma atividade científica, e lembrava magia, encantamento, truque de prestidigitador. (FREUD, 1917, p.524 - grifo meu)

Se em um primeiro momento, como vimos, Freud enfatizava o valor do estudo da magia como condição de construção de um método científico de tratamento psíquico, aqui, na última de suas Conferências Introdutórias, ele claramente opõe o estatuto do fazer mágico, encantatório; de uma atividade científica, denotando que a análise detida das primeiras seriam descartáveis para edificação das bases do tratamento psicanalítico.

Desde os meados da década de 1890, o tratamento por sugestão hipnótica foi encarado como um procedimento terapêutico na qual o sentido da doença, sua causa era excluída da possibilidade de ser investigada, ou seja, ao remover seu sintoma pela influência sugestiva do médico em sua instrução "ritual", a narrativa que sustentava o sintoma ou seu conteúdo ideativo, não tinham oportunidade de se dar a conhecer. A visão de Freud, além de considerar o impedimento da associação entre um método de cura e sua pesquisa, também se relaciona aos efeitos extraídos de tal tratamento, como se pode ver nesta citação que, podemos dizer, mantém-se atual para os critérios de avaliação dos tratamentos e diagnósticos em geral:

[Ao método sugestivo] faltava uma qualidade: o procedimento não era confiável em nenhum aspecto. Podia ser usado com um paciente, mas não em outro; conseguia muita coisa com um e bem pouco, com outro; e jamais se sabia por quê. Pior do que essa incerteza do procedimento era a falta de permanência dos seus êxitos. Se, passado pouco tempo, recebiam-se notícias do paciente, a antiga doença havia retornado, ou seu lugar tomado por nova doença [...] As condições que determinavam tal resultado favorável, contudo, permaneciam desconhecidas. (FREUD, 1917, p.523)

A terapia hipnótica, como se vê, além de dificultar a acumulação de dados e hipóteses sobre os fatores determinantes para a formação de um quadro patogênico em particular, mostrou-se ser menos eficaz em seus resultados, pois, ao invés de se tomar como norteador para a sistematização de sua ação os fatores etiológicos da doença, ela 
buscava agir apenas no fator sintomático, fazendo com que toda sua operação dependesse de um embate entre o poder de influência dos causadores do quadro e o poder da autoridade do médico. Portanto, há uma preocupação científica da parte de Freud nesta virada de paradigma teórico, haja vista, a necessidade de produzir conhecimento objetivo sobre o fenômeno de que se trata e uma técnica transformadora para justifique sua pertinência clínica, duas dimensões do problema intimamente relacionadas.

Entretanto, como bem notaram Léon Chertok e Isabelle Stengers, a operação realizada por Freud implicou uma revisão dos parâmetros de cientificidade, decisivos para regular e avaliar o progresso de uma disciplina. Após demonstrar que a lógica da técnica hipnótica fora derivada do modelo positivista-experimental do século XIX - por sua rígida divisão entre pesquisador-sujeito e paciente-objeto, e consequente pretensão de plena descrição do fenômeno, manipulação e reprodução dos procedimentos - os autores explicitam da seguinte maneira a problemática em que se encontrava o pai da psicanálise:

A cena analítica não podia ser purificada à maneira do recinto fechado químico, e o terapeuta não podia, portanto, construir "fatos" tecnicamente informados, fatos que pudessem afirmar serem "ditados" por aquilo com que estava lidando, já que aquilo que estava lidando escapava ao controle, e já que ele mesmo estava implicado, de maneira incontrolável, na situação que analisava. [...] Era simultaneamente herdeiro da questão que, desde Jussieu, a medicina havia deixado sem resposta como conceber uma investigação racional de efeitos que não eram compreendidos, como vencer o "horror do ininteligível" -, e do temor expresso pelo relatório secreto - a posição do terapeuta era perigosa, do ponto de vista dos costumes e dos julgamentos sociais (CHERTOK; STENGERS, 1989, p.74)

Por esta via, Freud a um só tempo conjuga a busca por um método de pesquisa e de tratamento que possibilitasse a enunciação de regras e postulados transmissíveis, verificáveis - portanto, acessíveis, a priori, a qualquer um - com o fator decisivo da 
experiência particular do sujeito envolvido na apreensão da técnica científica. Este último fato, que pode ser lido a partir da necessidade de transformação qualitativa daquele que pretende formar-se psicanalista, aproxima-se por analogia, segundo Chertok e Stengers, "com o papel dos xamãs, dos magos e de outros taumaturgos tradicionais" (Ibid., p.75). Ora, se a posição de renuncia à aspiração técnico-científica nos moldes do paradigma positivista fez Freud aproximar a posição do psicanalista, em seus condicionantes básicos, da posição de xamãs e magos, como explicar sua mudança de tom para com estes últimos, assim como a quase desaparição deste tema em seus escritos a partir do fim do século XIX?

Se por um lado, o lugar do psicanalista, em sua formação, aproximava-se do lugar, por exemplo, do xamã - hipótese trabalhada, como veremos, em Lévi-Strauss por outro, podemos dizer que o rechaço por parte de Freud desta aproximação, outrora celebrada, deveu-se à sua particular ambição de que a psicanálise obtivesse o amplo reconhecimento social como uma prática científica. Se em um primeiro momento, em Tratamento Psíquico, a aproximação com as práticas mágicas não colocavam em cheque o valor científico de sua metodologia, posteriormente, ao subverter o fazer ciência com a emergência da psicanálise, a aproximação tornara-se perigosa demais para ser sustentada publicamente. Entretanto, poderíamos delinear uma hipótese complementar a partir de uma perspectiva histórica, e lançar mão do fato de que o primeiro núcleo de trabalhos antropológicos que objetivou a apropriação sistemática das práticas de tratamento nativas, em um escopo transcultural, surge apenas no meio da década de 1910, sob a inspiração do psiquiatra e antropólogo britânico William Rivers, que será tratado no próximo capítulo.

Portanto, ao expressamente assimilar as formas de terapêutica antigas ou nativas ao procedimento hipnótico, Freud sintetiza da seguinte maneira os termos pelos quais estabelece a distinção entre o conjunto destas práticas e o tratamento psicanalítico:

[1] O tratamento hipnótico procura encobrir e dissimular algo existente na vida mental; o tratamento analítico visa a expor e eliminar algo. $\mathrm{O}$ primeiro age como cosmético, o segundo, como cirurgia. [2] O primeiro utiliza-se da sugestão, a fim de proibir os sintomas: fortalece as repressões, mas afora isso, deixa inalterados todos os processos que levaram à 
formação dos sintomas. $\mathrm{O}$ tratamento analítico faz seu impacto mais retrospectivamente, em direção às raízes, onde estão os conflitos que originaram os sintomas, e utiliza a sugestão a fim de modificar o resultado desses conflitos. [3] O tratamento hipnótico deixa o paciente inerte e imodificado, e, por esse motivo também, igualmente incapaz de resistir a alguma nova oportunidade de adoecer. Um tratamento analítico exige do médico, assim como do paciente, a realização de um trabalho sério, que é empregado para desfazer as resistências internas. Através da superação dessas resistências, a vida mental do paciente é modificada permanentemente, é elevada a um alto nível de evolução e fica protegida contra novas possibilidades de adoecer. (FREUD, 1917, p.526)

Em suma, o tratamento hipnótico opera, tomando a distinção clássica de Leonardo Da Vinci, pela via de porre, na qual seu executor enxerta na situação elementos que teriam como função impedir a manifestação patológica, mas que ao mesmo tempo não permitiriam uma investigação sobre as origens do patológico e uma transformação permanente no sujeito tratado. A terapia psicanalítica, pela via de levare, pretende extrair algo do quadro patológico, uma fala, uma verdade inaudita nos sintomas e "para esse fim preocupa-se com a gênese dos sintomas patológicos e com a trama psíquica da ideia patogênica, cuja eliminação é sua meta” (FREUD, 1905, p.270).

Do breve panorama delimitado até o momento, pode-se dizer que a inscrição de dados próprios à etnologia e à história surgem em Freud justamente no momento de travessia, ultrapassagem dos limites próprios aos paradigmas fundantes do modelo hegemônico, ao fim do século XIX, de clínica médica aplicada às psicopatologias. No interior deste processo, Freud buscou por modelos de leitura dos fenômenos patológicos que pudessem responder por um estatuto universal que contivesse em si não apenas a premissa do valor da recorrência geográfica e historicamente, mas que também pudessem agrupar fenômenos até então excluídos da dignidade do olhar médico, como as patologias ideogênicas.

A procura por tal princípio de leitura, estendeu-se à possibilidade de estabelecer um conjunto de princípios para o campo da terapêutica que sustentassem 
uma relação de homologia com a semiologia e etiologia derivada das duas. Em outros termos, Freud buscou estabelecer a medida na qual a eficácia do símbolo, do poder determinante das representações sobre o complexo sintomático, contribui para o estabelecimento das coordenadas de leitura da experiência clínica em seus fatores constituintes. No interior desta dupla problemática que Freud vislumbrará o primeiro uso da noção de mito.

\section{Inserção e influência da lógica mítica na constituição da clínica psicanalítica}

Vimos até aqui que as ciências sociais, em especial a história e a etnologia do fim do século XIX, estiveram presentes na obra freudiana desde suas primeiras considerações clínicas, antes mesmo da emergência da psicanálise como método de investigação e de cura. Neste percurso, analisamos três aspectos: (1) o valor de descrições patológicas de outras épocas e culturas como índice da possibilidade de universalização de um quadro nosográfico, a saber, a histeria; (2) analisamos como o modelo de tratamento encontrado nestas descrições poderia servir de base para a formação de uma terapêutica da palavra; e, por fim, (3) vimos qual o destino dado por Freud a tais terapêuticas, ou seja, como ele reinterpretou os métodos de tratamento antigos e de outros povos. No centro desse cenário, o psicanalista vienense lançará mão do recurso à noção de mito, enquanto uma tentativa de responder a um só tempo pela universalidade das formas de expressão patológicas (ou não) do psiquismo e pela particularidade inerente à produção da doença e da experiência clínica. Tomemos a via da análise da inserção e influência do mito como instrumento teórico e modelo semiológico para a leitura da clínica psicanalítica.

Um ponto importante no trajeto de inscrição do mito no cerne da interpretação das operações constitutivas do tratamento analítico é o abandono da teoria do trauma, teoria esta que abrigava, em Freud, o suporte etiológico da clínica da histeria em seus primórdios. A esse respeito Octave Mannoni escreve:

Enquanto persistir a teoria do trauma, a sexualidade infantil e o Édipo não poderão fazer sua entrada em cena, posto que nela os sintomas neuróticos permanecem dependentes de 
um acontecimento traumático real que os produziu e não das fantasias edipianas a criança. (MANNONI, 1976, p.35)

Tal teoria tinha como perspectiva a indução de que os sintomas neuróticos eram causados por uma experiência traumática, de caráter sexual, vivido na infância pelo paciente. Por traumático entendamos uma vivência que não teve uma possibilidade de resposta motora, afetiva, subjetiva à altura, por qualquer motivo, e que instaurou uma injunção corporalmente objetivada no sintoma que responderia a esse acontecimento. Em outros termos, o traumático fora lido em sua gênese por uma dificuldade de reação simbólica, que configurasse uma resposta pontual e eficaz a um evento específico. Com Joseph Breuer, Freud irá desenvolver um método de cura na qual se buscará atingir estas causas, remontando através da hipnose à pré-história psíquica da doença e possibilitando que, no interior do tratamento, por uma revivescência do evento, se realize uma descarga de afeto, da excitação que não pode ter espaço quando do evento traumático. Tal procedimento catártico foi denominado ab-reação e terá papel privilegiado na leitura lévi-straussiana da atividade do psicanalista.

No que diz respeito à teoria do trauma, tomemos Garcia-Roza:

Um dos pressupostos que sustentaram a teoria e a terapia da histeria no período que corresponde aos Estudos sobre $a$ histeria é o trauma do psíquico e seu conteúdo sexual. O que a teoria do trauma sustentava é que o neurótico, em sua infância, tinha sido vítima de uma sedução sexual real e que esse fato pelo seu caráter traumático teria sido recalcado e se transformado em núcleo patogênico cuja remoção só seria obtida com a ab-reação e a elaboração psíquica da experiência traumática. (GARCIA-ROZA, 1994, p. 93).

A questão da inscrição do traumático, de vez que Freud ainda não concebia a possibilidade da sexualidade na infância, fez com que ele desdobrasse a lógica temporal do trauma em dois momentos: o primeiro seria o da cena na qual a criança sofreria a sedução sexual, sem que tivesse ciência ou qualquer excitação pelo fato; o segundo momento ocorreria no início da puberdade, com a sexualidade já ativa, e uma cena ocasional despertasse, evocasse a primeira cena por um traço associativo, tornando 
patogênica a lembrança (Cf. GARCIA-ROZA, 1994). Eis as premissas pelas quais Freud escreve que "os histéricos sofrem de reminiscências" (FREUD, 1893, p.48). O evento em si não é traumático, mas o valor de trauma se marca por uma lembrança que se faz presente como experiência atual por uma associação. Os sintomas apresentados pelos doentes são aqui encarados como formas de expressão sígnicas de uma vivência temporalmente distante.

O abandono da teoria da sedução, pelo menos de sua formulação enquanto modelo que encadeia eventos "reais", terá um início efetivo a partir do fím de 1897 , quando Freud declara a Fliess, em correspondência, a seguinte confissão: "Confiar-lheei imediatamente um grande segredo que lentamente comecei a compreender nos últimos meses. Não acredito mais em minha Neurótica [teoria das neuroses].” (FREUD, Carta 69, p.350). Nesta mesma missiva ele apontará quatro motivos para tal descrença que aqui merecem menção: (1) o contínuo fracasso nas análises conduzidas, o que indicava que havia algum elemento faltando à consideração; (2) a desconfiança na fidedignidade dos relatos enquanto fatos vividos, pois dessa forma a perversão dos pais, inclusive o dele, deveria ser mais generalizada que o índice de histéricos; (3) A descoberta de que no inconsciente não há indicação de realidade, ou seja, "não se distingue entre verdade ou imaginação investida com afeto"; (4) e, por fim, o fato de que o "inconsciente nunca supera a resistência do consciente, sendo fracassada a expectativa de que o inconsciente possa ser totalmente dominado pelo consciente" (Ibid., p.351).

A cena da sedução, por estas premissas, passa a ser considerada por Freud não uma ilusão despropositada, irreal, mas narrativas matriciadas por fantasias decorrentes de impulsos sexuais intensos e, como veremos, de configuração edipiana. A fantasia articulada com a dimensão do desejo e a sexualidade infantil estavam postas na cena, a partir de então, plenamente psicanalítica. A realidade do sintoma passa a ser uma realidade psíquica, da fantasia enquanto expressão de um desejo recalcado.

Menos de um mês desta declaração de Freud, encontramos a primeira menção ao mito de Édipo, ainda não tornado “complexo" (termo que só aparecerá em 1910), mas já apresentando a sua estrutura futura. Tomemos sua primeira menção:

Um único pensamento de valor genérico revelou-se a mim. Verifiquei, também no meu caso, a paixão pela mãe e o 
ciúme do pai, e agora considero isso como um evento universal do início da infância [...] Sendo assim, podemos entender a força avassaladora de Oedipus Rex, apesar de todas as objeções levantadas pela razão contra a sua pressuposição do destino; e podemos entender por que os "dramas do destino" posteriores estavam fadados a fracassar lamentavelmente. [...] Mas a lenda grega capta uma compulsão que toda pessoa reconhece porque sente sua presença dentro de si mesma. Cada pessoa da plateia foi, um dia, em germe ou na fantasia, exatamente um Édipo como esse, e cada qual recua, horrorizada, diante da realização de sonho aqui transposta para a realidade, com toda a carga de recalcamento que separa seu estado infantil do seu estado atual. (FREUD, Carta 71, p.305 - grifo meu)

Esta primeira citação de Édipo, por mais que tenha no mito um valor meramente exemplar, já é plena de consequências para o que futuramente será descrito como o complexo edípico. Entretanto, devemos ressaltar que a citação nominal à tragédia sofocliana - cuja título transliterado do grego seria Oidipous Tyrannos - está acompanhada do reconhecimento dos elementos próprios à lógica trágica: (1) conflito entre expressão do herói e a ordem social estabelecida ("paixão pela mãe", "ciúme do pai”); (2) perda de relação imanente entre seu drama e a totalidade ontológica, a ordem divina do mundo ("razão contra a pressuposição do destino"); (3) a tentativa do herói de, em seu percurso, encontrar um lugar no mundo, remete-lhe à impotência de seus esforços (“dramas do destino fadados a fracassar”). Em suma, a apropriação do Édipo Rei como uma tragédia remete à dimensão do reconhecimento do abismo entre a existência e a essência do mundo (Cf. LUKÁCS, 1962, p.39), assim como a tentativa (fracassada) de superação de seu destino.

Embora estrutura trágica tenha seu valor dimensionado ao nível da narrativa, a função da remissão a Sófocles denota o valor da noção de mito: a "lenda" de Édipo é vista como sustentando uma relação intrínseca com os dramas universais do homem. Ela, portanto, seria mais que uma simples narrativa acerca dos conflitos do homem grego: seu potencial universalizante, estaria no fato de ser concebida como uma narrativa que captaria os elementos em que cada pessoa reconheceria seu drama recalcado e, portanto, inconsciente. A plateia seria constituída de Édipos que recusam as 
realizações impostas por um destino determinado a partir do desejo recalcado de cada um. O gozo, como misto de satisfação e horror, por tal realização, faz aqui sua presença. O Édipo, portanto, no interior da particularidade de um drama historicamente datado, revelaria uma dimensão universal que transcende o local e tempo em que foi registrado, uma dimensão que uniria os antigos gregos, a cada e todos os homens.

Importante notar que a entrada do mito na conceituação da cena analítica, tem como correlata uma transformação global no estatuto tanto da dinâmica temporal dos fenômenos analisados na clínica, quanto na insígnia de realidade imposto a estes. Com o que diz respeito a este último aspecto, Freud é claro ao afirmar que a memória e a fantasia são indissociadas, reestruturando continuamente o valor de verdade da experiência presente, passada e futura. Para tratarmos da temporalidade colocada em jogo nesta nova concepção de realidade, a realidade psíquica, tomemos a seguinte citação:

\begin{abstract}
A atividade imaginativa - as diversas fantasias, castelos no ar e devaneios — adaptam-se às impressões mutáveis que o sujeito tem da vida, alterando-se a cada mudança de sua situação e recebendo de cada nova impressão ativa uma espécie de 'carimbo de data de fabricação.' A relação entre a fantasia e o tempo é, em geral, muito importante. É como se ela flutuasse entre três tempos — os três momentos abrangidos pela nossa ideação. $O$ trabalho mental vincula-se a uma impressão atual, a alguma ocasião motivadora no presente que foi capaz de despertar um dos desejos principais do sujeito. Dali, retrocede à lembrança de uma experiência anterior (geralmente da infância) na qual esse desejo foi realizado, criando uma situação referente ao futuro que representa a realização do desejo. O que se cria então é um devaneio ou fantasia, que encerra traços de sua origem a partir da ocasião que o provocou e a partir da lembrança. Dessa forma o passado, o presente e o futuro são entrelaçados pelo fio do desejo que os une. (FREUD, 1908, p.153)
\end{abstract}


Veremos como tal rearticulação temporal, assim como o estatuto da realidade psíquica se relacionam com o papel do mito na experiência clínica freudiana, na qual o complexo de Édipo terá um valor central. Mas antes de traçar um percurso pelo Édipo, tratemos de notar quais os usos freudianos da noção de mito.

\section{1. Édipo e a primeira versão de uma teoria do mito}

A primeira referência ao complexo edipiano antecede em dois meses a primeira tentativa de formulação do que poderíamos extrair como uma teoria do mito em Freud, cuja reconstrução buscarei traçar na presente seção. Esta data de uma carta enviada a Fliess em dezembro de $1897^{2}$, vejamos quais os termos aí presentes:

Imagine você isso que pode ser os mitos endopsíquicos? [...] a obscura percepção interna pelo sujeito de seu próprio aparelho psíquico suscita a ilusão que, naturalmente, se encontra projetados desde fora e, de maneira característica, no porvir, em um mais além. A imortalidade, a recompensa, tudo o além tais são as concepções de nossa psique interna... é uma psico-mitologia. (FREUD, Carta de 12-12-1897, p.210)

Como bem nos lembra Alain Delrieu (2004), este modelo da função do mito na economia conceitual freudiana tem seu valor melhor compreendido quando articulado com uma importante passagem de Psicopatologia da Vida Cotidiana:

Uma grande parte da concepção mitológica do mundo, que se entende bem distante, cujo longo alcance se estende até as mais modernas religiões, nada mais é do que psicologia projetada sobre o mundo exterior. O reconhecimento obscuro (a percepção, por assim dizer, endopsíquica) da existência de fatores e de fatos psíquicos próprios ao inconsciente se reflete (...) na construção de uma realidade suprassensível [sobrenatural] que a ciência tem por tarefa retransformar em

${ }^{2}$ É só tardiamente no artigo de 1924 consagrado a um tema inteiramente novo, $O$ declínio do complexo de Édipo, que Freud tenta articular plenamente a fórmula do complexo de Édipo, quando este estava presente em seu pensamento desde o início. (Cf. LACAN, S.IV, p.220) 
psicologia do inconsciente. Poderíamos nos poupar de explicar os mitos do paraíso e do pecado original, de Deus, do bem e do mal, da imortalidade, etc., e transformar a metafísica em metapsicologia. (FREUD, 1902, p. 309)

O mito neste primeiro momento da obra freudiana é entendido, portanto, como portador de uma substancial potencialidade de explicitar os conflitos e os mecanismos psíquicos do homem. Na mesma série dos sonhos, dos chistes e das formações sintomáticas, o mito, em sua função de matéria-prima de formalização de uma ciência da vida psíquica inconsciente, teria a vantagem de enunciar em sua narrativa uma projeção do "mundo interno" com um menor grau de dissimulação frente a outras formações do inconsciente, expressa na maior confusão em seus temas, tramas (Cf. FREUD, 1907). A construção de uma metapsicologia estava desde este momento articulada a uma maior consideração pelo mito. Se ele por si não designa diretamente (ou seja, sem um esforço mínimo de tradução) os conflitos psíquicos individuais, estes terão sua base em algum tipo de narrativa mítica, como vemos pelo recurso freudiano a Édipo, Narciso, Horda Primeva, Moisés, etc.

Como já se pode notar, Freud opera, por tais considerações, um reconhecimento do caráter universal do fato mítico posto que, se em outros lugares e tempos eles têm ou tiveram um papel prevalente na Weltanschauung ${ }^{3}$ (FREUD, 1902), não deixaram de por isso estar presentes, em sua forma homóloga, no homem moderno. Presentes, devemos ressaltar, não apenas no modo de efetivação de sua forma, quanto pelos "temas, inquietudes e enigmas que se fazem constantes nos dramas humanos" (DELRIEU, 2004, p.30).

O mito, portanto, enquanto a projeção de conflitos deficitariamente reconhecidos, responde desde sua origem na obra freudiana por um meio de acesso privilegiado à psicologia do inconsciente. Em outras palavras, ele marca uma das vias régias de registro e investigação da dimensão universal da experiência subjetiva problemática presente em Freud, como vimos, desde os primeiros momentos de sua atividade clínica .

${ }^{3}$ Weltanschauung é o termo alemão que designa uma cosmovisão, ou seja, seja uma posição ontológica. Sua origem conduz a Herbert von Humboldt (1856) e é formado pelo termo Welt, traduzido por "meio" como em meio ambiente, ou mesmo por "mundo" em uma acepção próxima, de mundo circundante; e pelo termo anschauung, que designa um "modo de visão", mas aqui ligado ao seu aspecto sensível, como em uma percepção sensível. 


\subsection{Entre Devaneios, Romances e Teorias: incidências da lógica mítica}

A partir do período de 1907-1909, Freud irá introduzir importantes hipóteses que repercutirão na compreensão e ampliação da importância do fato mítico. Acompanhemos seus passos a partir de Escritores criativos e devaneios (FREUD, 1908a) - escrito em que trata principalmente do papel das fantasias sob a ótica da produção artística - no qual Freud faz a seguinte consideração:

Não devemos esquecer, entretanto, de examinar aquele outro gênero de obras imaginativas, que não são uma criação original do autor, mas uma reformulação de material preexistente e conhecido. Mesmo nessas obras o escritor conserva uma certa independência que se manifesta na escolha do material e nas alterações do mesmo, às vezes muito amplas. Embora esse material não seja novo, procede do tesouro popular dos mitos, lendas e contos de fadas. Ainda está incompleto o estudo de tais construções da psicologia dos povos, mas é muito provável que os mitos, por exemplo, sejam vestígios distorcidos de fantasias plenas de desejos de nações inteiras, os sonhos seculares da humanidade jovem. (FREUD, 1908a, p.157 [grifo do autor])

Além de reiterar a homologia das esferas individuais e coletivas nas formações do inconsciente, Freud coloca os mitos no rol de produções populares que serviriam de base para a construção de outras narrativas. Entretanto, a passagem do registro coletivo, social, ao individual implica uma alteração do estatuto autoral, posto que a dinâmica coletiva é em princípio destituída da lugar diferencial do autor, ao contrário do que acontece com as criações individuais. Duas consequências decorrem deste ponto: a primeira é a de que a criação individual, a despeito de participar da lógica do mito coletivo - dado que de início ela já é uma versão a serviço da construção de outras versões -, esta criação permite uma inscrição, um registro na história deste sujeito. Em outros termos, por mais que seja uma versão articulada ao conjunto de outras versões, ela recebe de seu autor uma marca singular. O segundo ponto a extrair dessa passagem é 
o fato de que, em Freud, mesmo um mito coletivo - por princípio, a-histórico e sem autoria - tem sua gênese marcada pela transformação de uma "fantasia anterior, plena de desejo". Como veremos em Totem e Tabu (1913), para Freud a lógica universalizante do mito não deve ser dissociada de seu valor de experiência, inscrita na história.

O termo para escritor criativo em alemão, Dichter, traz também a conotação de uma posição de enunciação que reestrutura o conjunto da literatura e da língua, podendo ser traduzido por poeta ou aedo. A hipótese de Freud é que a atividade do Dichter de criar novos mundos esteja em consonância com o brincar das crianças no que diz respeito a um jogo de fantasia que possibilitaria sua expressão de modo não penoso ao sujeito (FREUD, 1908a, p.152). O infantil, portanto, entra em jogo na consideração sobre o mito (FREUD, 1907, p.141). Mas "infantil" aqui entendido também enquanto homologia entre a economia psíquica do brincar da criança, do criar mítico (futuramente também representado pela figura do selvagem) e a formação sintomática do doente nervoso, que padece da impossibilidade de lidar com a libido emanada de seu desejo inconsciente. A articulação destas três esferas tomará maior relevo quando examinarmos Totem e Tabu, cujo subtítulo - Alguns Pontos de Concordância entre a Vida Mental dos Selvagens e dos Neuróticos - remete justamente a este tema.

Ainda neste período, mais exatamente no ano seguinte à publicação de Escritores criativos, Freud tratará de um texto central para a consideração da teoria do mito em sua obra, a saber, Sobre as teorias sexuais infantis (1908b). Neste pequeno escrito encontramo-lo asseverando que "o conhecimento das teorias sexuais infantis, tais como as concebe a mente da criança, pode ter interesse em mais de um sentido [portanto, não somente descritivo] - até mesmo, surpreendentemente, para a elucidação dos mitos e contos de fadas" (FREUD, 1908b, p.215). Podemos, portanto, considerar, em um primeiro momento, que o conhecimento das teorias sexuais infantis esclareceria em alguma medida os mitos e contos por partilharem, ele nos diz em seguida, o enigma da origem das crianças e todos os temas decorrentes deste ponto (Cf. DELRIEU, 2008, p.32)

No entanto, este texto, para além da possibilidade vislumbrada por Freud de encontrar uma recorrência temática entre as teorias infantis e os mitos, aponta para uma faceta decerto relevante dos últimos: o mito, em sua justaposição com a noção de teoria, teria um valor de verdade maior que mera da especulação epistêmica, simples jogo de 
conhecimento, ele seria uma teoria no sentido original do termo, marcaria a posição para uma visão (theoros, em grego) de mundo. O mito, como a teoria infantil, trataria de marcar uma posição em uma cosmovisão (Weltanschauung) com efeitos sobre a própria experiência das crianças. Teriam, portanto, um valor ontológico em sua formulação e na determinação da experiência. Vejamos este ponto mais detidamente.

Ao enfatizar o valor de tais teorias, Freud afirma que seu conhecimento seria ainda de grande auxílio para a compreensão das neuroses, já que "nestas atuam as teorias infantis, exercendo uma decisiva influência sobre a forma assumida pelos sintomas" (FREUD, 1908b, p. 215). O complexo de castração está aqui em causa. Para introduzir esta experiência de horror frente a potencial perda de si mesmo ou de uma parte de si, Freud comenta o exemplo da chegada de um bebê à família. A perda, real ou apenas temida, dos carinhos parentais faz com que as crianças se questionem sobre a origem dos bebês, primeira grande problemática presente no drama infantil e nos mitos. A questão da origem é, segundo Freud, "produto de uma exigência vital para que possa impedir a repetição desse evento temido" (Ibidem, p.216), evento que marcou a destituição de sua posição privilegiada perante o desejo dos pais.

Frente à questão dos filhos, os pais, dotados de pudor para os assuntos sexuais, fazem um uso da mitologia diverso daquele que preconiza Freud: valem-se dela para uma explicação que fuja com a verdade, que a recalque, recorrendo então aos contos da cegonha, do repolho e de outros modos esdrúxulos de reprodução. Em geral, as crianças não se contentam com tais respostas e, sem a confiança nos adultos, passam a realizar suas pesquisas sexuais de forma independente. Ainda sem a possibilidade de apreensão psíquica da diferença sexual, ou seja, da castração, formulam teorias alternativas para responder à questão das origens: teoria da atribuição universal do pênis, teoria da reprodução cloacal e, por último, a teoria do ato sexual como fruto de uma violência, de uma dominação de um dos parceiros, em geral, o pai. As crianças chegam mesmo a falsear percepções que contradizem sua teoria do mundo, como quando se deparam com alguém sem pênis e formulam que o Wiwimacher da pessoa é pequeno demais para se enxergar (FREUD, 1908b, p. 219).

O caráter típico, recorrente destas teorias - enquanto mitos infantis - está relacionado, segundo Freud, ao fato de suas configurações particulares surgirem das demandas próprias à constituição psicossexual da criança, portanto, de uma experiência 
marcada por conflitos que apresentam certa regularidade. Mesmo que pretensamente falsas, esta teorias infantis trazem, cada uma delas, um fragmento de verdade, algo próximo do que encontramos, em adultos, nas teorias científicas sobre o universo em geral, "problemas por demais complexos para a compreensão humana" (FREUD, 1908b, p.218). Por seu valor de verdade, ou seja, de remeter a um conflito que envolve toda a existência da criança, tais teorias se inscrevem como um ponto de articulação e interseção entre a lógica do mito - marcada pela repetição, universal - e a lógica da fantasia - que inscreve a singularidade da história de um indivíduo. Em um comentário sobre o estatuto de tais teorias, Lacan nos diz:

O que se chama de teorias infantis, i.e., a atividade de pesquisa que é a da criança em relação à realidade sexual, responde a uma necessidade inteiramente diversa daquilo a que chamamos, aliás indevidamente, com uma noção difusa, a atividade intelectual, cujo caráter superestrutural é admitido, de maneira mais ou menos implícita, no fundo de crença que ordena a consciência comum. É de uma coisa inteiramente diferente que se trata nesta atividade. Ela é bem mais profunda, se podemos empregar este termo. Ela concerne ao conjunto do corpo. Ela envolve toda a atividade do sujeito, e motiva o que se pode chamar de seus temas afetivos [...] ela é, em suma, correlata de toda uma série de realizações no sentido amplo, manifestando-se por ações absolutamente irredutíveis a fins utilitários. (LACAN, S.IV, p.256).

O complexo de castração, portanto, colocaria um problema de ordem ontológica à criança, que responderia com os meios-limites que tem à disposição. Quem ela é, qual sua posição possível na dinâmica das suas relações. Diante deste encontro com uma posição de impasse, de impossibilidade de simbolização, elas formulam suas teorias que, tanto pela forma (por seu esquematismo e articulação significante) como pela função (dar tratamento simbólico a um real inassimilável), respondem à noção de mito e o valor de experiência pressuposto neste.

Neste mesmo período encontramos ainda, digno de uma contribuição para a teoria do mito em Freud, o pequeno escrito O romance familiar do neurótico (1909b), 
no qual é descrito a intrincada relação entre o nível da fantasia e o nível dos saberes, fatos e eventos que estariam à disposição do sujeito para formular seu drama. $\mathrm{O}$ romance familiar aparece como análogo aos devaneios e às produções que se apresentam agenciados pela fantasia de negação da castração, em seu sentido amplo, de perda da posição privilegiada no desejo dos pais. Análogo, mas teria uma característica de se "ocupar das relações familiares", portanto, representando narrativas individuais sobre seus parentes que teriam como função realizar seus desejos e, deste modo, retificar os déficits e excessos da vida "real". Os exemplos trazidos por Freud deste modo de romance, estariam centrados no sentimento de não ser filho legítimo dos pais, sendo portanto, filho de alguém de maior importância (como na análise da história de Moisés (FREUD, 1939)); a crença de que o pai foi traído pela mãe, portanto, substituindo-o unicamente na história de sua origem; ou mesmo na imputação de que seus irmãos seriam bastardos, com fins de negar a proibição parental caso se sentisse sexualmente atraído.

O romance, enquanto forma literária surgida historicamente no contexto da modernidade, é representado como a modalidade narrativa "própria de uma era para a qual a totalidade extensiva da vida não é mais dada de modo evidente, para a qual a imanência do sentido à vida tornou-se problemática" (LUKÁCS, 1962, p.55). Ao nomear "romance familiar", Freud inscreve esse conjunto narrativo na historicidade configurada essencialmente pelo conflito entre a constelação de personagens familiares, real ou virtualmente, em torno da temática da filiação.

Entretanto, este texto salienta dois aspectos importantes do que consideramos a inserção do mito na obra freudiana: o primeiro, já citado, é o da tipicidade do deslocamento do lugar ocupado pelo pai real por outro que sustentaria de forma mais consistente a potência simbólica. Freud descreve o ponto da seguinte maneira:

No período já mencionado a imaginação da criança entrega-se à tarefa de libertar-se dos pais que desceram em sua estima, e de substituí-los por outros, em geral de uma posição social mais elevada. Nessa conexão ela lançará mão de quaisquer coincidências oportunas de sua experiência real, tal como quando trava conhecimento com o senhor da Casa Grande ou com o dono de alguma grande propriedade, se mora no 
campo, ou com algum membro da aristocracia, se mora na cidade. Esses acontecimentos fortuitos despertam a inveja da criança, que encontra expressão numa fantasia em que seus pais são substituídos por outros de melhor linhagem. A técnica utilizada no desenvolvimento dessas fantasias (que, naturalmente, são conscientes nesse período) depende da inventividade e do material à disposição da criança. (FREUD, 1909b, p.244)

Em Teorias sexuais infantis, vimos a regularidade destas criações sendo entendidas por Freud a partir da influência do fator sexual no desenvolvimento da libido na criança e de seu papel na construção da fantasia inconsciente. A despeito de ser temporalmente próximo, vemos em $O$ romance familiar a tônica recair não na convergência, mas na divergência de narrativas que terão sua forma final alcançada a partir de uma assimilação entre os fatores sexuais e a contingência dos eventos e encontros da criança em sua experiência. Como já visto em Escritores criativos e devaneios: a atividade imaginativa não é estereotipada a priori, "ao contrário, adapta-se às impressões mutáveis que o sujeito tem da vida, alterando-se a cada mudança de sua situação e recebendo de cada nova impressão ativa uma espécie de 'carimbo de data de fabricação"” (FREUD, 1908a, p.153).

Algo próximo acontece com o mito: segundo Freud, o valor uniforme das narrativas acerca da origem ou do fim da existência, seja na esfera individual, seja na coletiva, não se inscreve por uma simbólica transcendental, mas sim, pela tentativa de dar respostas a conflitos universais a partir de elementos historicamente apropriados. Em outros termos, um mito - narrativa atemporal, sem "data de fabricação" - se formaria por e através de um conjunto de elementos registrados como "impressões ativas". Por tal concepção, Freud estaria em acordo com a concepção lévi-straussiana do conceito. Compreendendo o inconsciente como estruturalmente vazio, apenas dotando de formas os conteúdos imaginários, o antropólogo vê no mito esta função de articulação, poderíamos dizer significantes, entre conteúdos (LÉVI-STRAUSS, 1949b). No entanto, como salienta Alain Delrieu (2004), esta faceta do entendimento da funçãomito por Freud não deixa de estar articulada com uma função denotativa e metafórica. Os mitos, em Freud, individuais ou coletivos, por mais plurais que sejam, convergem em tratar de algum assunto especial. Eles falam dos temas que reenviam o homem à sua 
divisão fundante: o sexual e da morte, cujo ponto de articulação se encontra na temática da filiação.

$\mathrm{O}$ segundo aspecto que se encontra em $O$ romance familiar do neurótico acerca do mito, trata de um ponto que será, doravante, mais detalhado em suas premissas, a saber, a articulação do mecanismo de defesa paranoico com a noção de projeção. Como vimos, as narrativas familiares tinham como princípio de estruturação o desdobramento dos personagens: para uma família deficiente, outra de maior prestígio; para um pai carente, outro pai, ou pais-amantes da mãe, etc. Encontramos um processo análogo nas análises de seu Notas psicanalíticas sobre um relato autobiográfico de um caso de paranoia (dementia paranoides) (1911), também conhecido por Caso Schreber, Freud escreve aí:

Se efetuarmos um levantamento das ilusões como um todo, veremos que o perseguidor se acha dividido em Flechsig e Deus; exatamente da mesma maneira, o próprio Flechsig, subseqüentemente, cinde-se em duas personalidades, o 'superior' e o 'médio' Flechsig, e Deus, em Deus 'inferior' e 'superior' [...] Um processo de decomposição desse tipo é muito característico da paranóia. A paranóia decompõe, tal como a histeria condensa. Ou antes, a paranóia reduz novamente a seus elementos os produtos das condensações e identificações realizadas no inconsciente. (FREUD, 1911, p.69)

Em uma nota tímida de rodapé, Freud atesta que Otto Rank teria encontrado o mesmo tipo de mecanismo no material mítico analisado em Der mythus von der Geburt des Helden (1909). Entretanto, alguns anos antes, Freud já havia relatado aos seus companheiros da Sociedade Psicanalítica de Viena a ligação entre a paranoia e a formação dos mitos, em suas palavras:

Em comparação com o sonho, o mito e o fantasia são paranoides, eles decompõem no lugar de condensar e, por essa razão, contém frequentemente duplos; o mesmo personagem, quando visto no mesmo motivo, aparece sob formas duplicadas. [...] O mito tem uma qualidade paranoide. A ele corresponde o 
fato que, na paranoia, a história é contada abertamente, sem por vezes deixar acessível suas motivações. $\mathrm{O}$ traço consistente, que separa o que é unido na imaginação, é estreitamente ligado à qualidade paranoide. De onde as multiplicações, dissociações, etc. (FREUD 14-10-1908 apud DELRIEU, 2004)

Esta estrutura de desdobramento dos membros terá maior relevância quando analisarmos a leitura lacaniana presente em $O$ mito individual do neurótico (1953a), texto no qual ele apresenta o mito como articulador de membros simetricamente duplicados nas narrativas que constituem o drama de outro caso freudiano, este de uma neurose obsessiva, a saber, o caso do Homem dos Ratos (FREUD, 1909a) Em linhas gerais, ela apresenta um aspecto fundamental do mito: estabelecer a relação diferencial, discreta, entre os termos presentes no drama originário que guia neurótico em sua vivência sintomática. Portanto, se há na lógica mítica um efeito centrípeto, centralizador das significações sob uma matriz reguladora, aquela que trata do agenciamento significante sobre determinados eventos, por outro, ela busca explorar o centro do enigma fundante do sujeito a partir da transformação de relações de contradição em outras oposições, de forma a operar pelo o que poderíamos chamar de dialética nãosintética. Mas voltemos à trilha dos desenvolvimentos freudianos sobre o mito.

Um último desenvolvimento a que nos deteremos na teoria freudiana do mito, ou seja, um desenvolvimento posterior ao momento de sua obra a que nos detivemos, se dá a partir da concepção do simbolismo originário. Na décima de suas Conferências Introdutórias, Freud nos diz sobre este tema:

Deparamo-nos com o fato de que o sonhador tem à disposição uma forma simbólica de expressão que ele desconhece na vida desperta e não reconhece [...] Esse mesmo simbolismo, como vimos, é empregada nos mitos e contos de fadas, pelas pessoas em seus ditados e em suas canções, pelo uso idiomático coloquial e pela imaginação poética. O campo do simbolismo é imensamente amplo e o simbolismo onírico constitui apenas uma parte dele. [...] o simbolismo nas outras áreas que mencionei não é absolutamente apenas simbolismo sexual, ao passo que nos sonhos os símbolos são empregados 
quase exclusivamente de objetos e relações sexuais. (FREUD, 1916, p. 197-9)

Um importante ponto que salta aos olhos é o franco reconhecimento que no que se refere ao simbolismo, o campo abarcado pela psicanálise é apenas uma fração da totalidade de possibilidades de expressão simbólica. Em acordo com a teoria psicanalítica do inconsciente, encontramos aqui uma inegável contestação das críticas de que Freud seria um autor pansexualista, ou seja, que estaria munido de uma teoria que reverteria todo traço manifesto, independente de sua fonte, em um sentido sexualizado, no sentido popular do termo.

A primeira menção a uma simbólica universal expressa nos sonhos - e, portanto, comum às neuroses, lendas, tradições e mitos - aparece em uma nota acrescentada à Interpretação dos Sonhos em 1909. Sua área de atuação seria privilegiada lá onde o arcaico domina (sociedade primitiva), ressurge (sonhos) ou persiste (neurose) (DELRIEU, 2004, p.38). No entanto, duas características deste simbolismo originário merecem destaque: o primeiro é o fato de o simbólico estar aqui associado a um pensamento não discursivo, um pensamento por imagem (FREUD, 5-61911 apud DELRIEU, 2004, p.38), em outros termos, encontraríamos neste simbolismo uma representação de coisa sem representação de palavra. A partir de $O$ inconsciente (FREUD, 1915), podemos dizer que o simbolismo se localiza entre as instâncias inconsciente e pré-consciente, esperando por uma inscrição verbal. A ligação de uma faceta imagética é central para a análise lévi-straussiana da lógica do mito, como o veremos em O Pensamento Selvagem (LÉVI-STRAUSS, 1962).

O segundo ponto é o de que a origem deste simbolismo é infantil, ontogenética, dado o fato que as crianças passariam por estados semelhantes ao longo desde o início de suas vidas. Contrapondo-se à perspectiva junguiana dos arquétipos, Freud não compreende que os símbolos e seus conteúdos sejam herdados desde a pré-história (FREUD, 10-08-1910 apud DELRIEU, 2004)

Para resumir as diversas faces imputadas ao mito em nossa leitura da teorização freudiana, esquematizaremos aqui, de forma sincrônica, seu entendimento. A partir do que vimos o mito foi considerado como: 
1) Principio de formalização para a ciência do inconsciente. Através da noção de mito endopsíquico projetado, Freud considerou derivar uma metapsicologia.

2) Análogo ao brincar infantil e à atividade do Dichter, no que se refere à criação de novos mundos. Ao ler em sua função a capacidade de lidar com conteúdos recalcados, Freud estabelece um vínculo entre a mitologia infantil, neurótica e nativa.

3) Produção que responde a um só tempo pela universalidade dos conflitos constitutivos da humanidade e pela inscrição particular de cada um em seu drama. Esta vertente articula a questão da autoria que poderíamos esquematizar em dois polos indissociáveis, para Freud: de um lado, a mitologia individual - autoral, registrada no interior de uma dimensão histórica - e a mitologia popular, coletiva - não-autoral, mas que para o psicanalista não deixa de inscrever uma experiência prévia, de ordem histórica.

4) Uma teoria, no sentido forte do termo, por ter valor ontológico sobre a experiência subjetiva. Ou seja, um meio eficaz através do qual suas vivências seriam construídas, mas também modificadas, transformadas.

5) Uma espécie de discurso passível de adaptar sua narrativa a novas impressões, portanto aberto à contingência.

6) Narrativa que assimila os mecanismos paranoides de desdobramento dos personagens e ausência de forte censura sobre o recalcado.

7) Forma de inscrição não verbal no psiquismo que participa do simbolismo originário.

\section{Dois eixos do mito em Freud: semiologia e transferência}

Desde a primeira menção de Freud a um mito, em especial à tragédia do Édipo $R e i$, temos o reconhecimento da possibilidade de articulação de um drama individual em narrativas compartilhadas desde os "tempos imemoriais". Ainda que não assimile os mitos coletivos aos individuais, podemos ver em Freud, analogamente ao que veremos na abordagem da antropologia estrutural de Lévi-Strauss e da releitura de Lacan, a utilização do mito e sua lógica como referência para a condição e determinação das 
particularidades próprias da neurose. $\mathrm{O}$ mito em Freud, portanto, enquanto uma das bases para uma semiologia da clínica psicanalítica fica entre o individual (particular, histórico) e o coletivo (universal, estrutural), princípio estruturante de onde a rede sintomática retira seu valor e significação.

Encontra-se aqui o surgimento de dois eixos da concepção do mito para a psicanálise em seus primórdios que serão doravante analisados: por um lado, o mito como um discurso estruturado por certas posições específicas que têm sua semiologia à disposição da análise. Por esta via, o mito deve ser analisado como o mito de Totem e Tabu, de Narciso, de Édipo em especial, etc., em seus determinantes simbólicos; por outro lado, o mito enquanto uma estrutura fundamental de agenciamento, segundo sua lógica, dos elementos dados na situação de sua formação. Ele surge nas narrativas sobre sintomas, inibições e angústias, narrativas estas essencialmente relacionais, mas que não estão apenas presentes em sua expressão verbal, posto que no próprio mecanismo de análise há a articulação de sua forma no interior do tratamento, no interior da relação entre analisando e analista. O processo de que se trata, responsável por este jogo temporal próprio do mito na clínica é o conhecido pela noção de transferência. Comecemos por este segundo ponto, analisando a relação entre transferência e mito, para em seguida perscrutar sobre a análise das recorrências deste.

A noção de transferência, Übertragung no original em alemão, é definida por Freud, em uma de suas primeiras tentativas de delimitação de sua dinâmica no interior do tratamento, como uma série de "reimpressões, cópias de moções e das fantasias que devem ser despertadas e tornadas conscientes à medida dos progressos da análise; o que é característico da sua espécie é a substituição pela pessoa do médico de uma pessoa anteriormente conhecida" (FREUD, 1905, p.113). A transferência em Freud, portanto, marca uma atualização de desejo inconsciente sobre determinados objetos no quadro de um certo tipo de relação estabelecida com eles e, eminentemente, no quadro da relação analítica. (LAPLANCHE, 1974, p.514).

Como observamos em Tratamento psíquico (tratamento anímico) (FREUD, 1890), durante um tratamento o paciente pode dotar de uma potência quase mágica a pessoa do analista e exagerar o poder de influência em sua vida. No entanto, a conceptualização da transferência marca uma articulação desse fenômeno, deste investimento libidinal excessivo no analista, com uma série psíquica (Cf. FREUD, 
1912) determinante na formação da neurose. A vinculação com a figura do analista, desse modo, estaria relacionada às "modalidades de condução da vida erótica inacessíveis imediatamente, posto que inconscientes" (FREUD, 1912, p.133). A transferência, portanto, por essa definição, sustentaria em sua dinâmica a reprodução, atualização, ou ainda mise en scène de uma versão anterior de tal relação libidinal.

O primeiro uso do termo aparece já em A Interpretação dos Sonhos, 1900, e denota o processo de deslocamento do valor de uma representação inconsciente, sem acesso à consciência por conta do recalque, para uma representação pré-consciente anódina que à primeira permitiria se expressar (FREUD, 1900, p.599). Vemos aqui como o agenciamento do significante, enquanto princípio estruturante deste processo posteriormente, imputado em seu funcionamento essencialmente no setting clínico - faz já sua presença. Deve-se ressaltar que tal estruturação da realidade está também relacionada à resistência ao tratamento, posto que, um tipo de ligação excessivamente positivo ou negativo, desviam seu foco e dificultam sua continuidade (FREUD, 1909a, p.209). No entanto, uma marca central do poder de agenciamento dos elementos atuais pelo processo transferência é encontrada na seguinte passagem:

Os impulsos inconscientes não desejam ser recordados da maneira pela qual o tratamento quer que o sejam, mas esforçam-se por reproduzir-se de acordo com a atemporalidade do inconsciente e sua capacidade de alucinação. Tal como acontece nos sonhos, o paciente encara os produtos do despertar de seus impulsos inconscientes como contemporâneos e reais (FREUD, 1909a, p. 143)

A associação da lógica do mito com a noção de transferência se encontra aqui, primeiramente, em relação à lógica temporal pressuposta em ambas. Como vimos, desde o início da psicanálise o valor conferido, no plano associativo, ao passado narrado deixa de ser considerado em sua simples reprodução imediata deste passado, para ser a reconstrução, pela faculdade da memória, deste passado a partir de uma posição desejante, ou como diria Lévi-Strauss, uma versão acima de tudo. Tanto no mito, quanto em sua inscrição no interior da transferência, há a consideração deste processo em seu componente próprio da compulsão à repetição - em íntima relação entre os fatores do presente, passado e futuro. A atualização do drama constitutivo do paciente, 
de seu mito individual, é encenada, colocada em cena pelo processo homólogo de transferência. Eis como Freud concebe seu valor para a sistematização da experiência clínica:

No entanto, o principal meio de domar a compulsão de repetição do paciente e transformá-la num motivo para a recordação está no manejo da transferência. [...]. Nós a admitimos na transferência, como numa arena em que lhe é facultado se desenvolver em quase completa liberdade, e onde é obrigada a nos apresentar tudo o que, em matéria de instintos patogênicos, se ocultou na vida psíquica do analisando. Quando o paciente se mostra solícito a ponto de respeitar as condições básicas do tratamento, conseguimos normalmente dar um novo significado de transferência a todos os sintomas da doença, substituindo sua neurose ordinária por uma neurose de transferência, da qual ele pode ser curado pelo trabalho terapêutico. Assim a transferência cria uma zona intermediária entre a doença e a vida, através da qual se efetua a transição de uma para a outra. O novo estado assumiu todas as características da doença, mas representa uma enfermidade artificial, em toda parte acessível à nossa interferência. (FREUD, 1914, p.201)

A noção de transferência, portanto, responde em Freud ao estatuto eficaz da palavra, à sua potencial de transformação, essencial para o estabelecimento de uma terapêutica como a psicanalítica. Como vimos, a sistematização deste campo da experiência é reconhecido como uma necessidade teórica desde os primeiros escritos de Freud. Seu grande passo foi incluir a dinâmica da transferência como a mola do tratamento. Entretanto, no interior dessa lógica transformativa, a repetição e seus determinantes devem ser reconhecidos como fator seminal para a possibilidade de descrição e conceituação da atividade clínica. No interior desse contexto que o mito aparece, enquanto articulador da experiência clínica, como estabelecendo um ponto de contato entre tal eficácia simbólica e a regularidade própria dos complexos ideativos.

Um ponto de passagem entre esta primeira faceta do mito, enquanto princípio estruturante, e sua determinação semiológica, ou seja, sua configuração recorrente atualizada, pode ser encontrado na argumentação de Jean Laplanche sobre o fato de que 
até 1912 nos escritos freudianos, a transferência ainda não fazia, teoricamente, parte necessária da relação terapêutica. Mais ainda: até a referida data as transferências seriam consideradas plurais não tendendo para alguma configuração específica prévia. No entanto, sua articulação com a trama edípica terá consequências essenciais para a inscrição do mito na psicanálise. Em suas palavras:

A integração progressiva da descoberta do complexo de Édipo não poderia deixar de repercutir na forma como Freud compreende a transferência. [...] $\mathrm{Na}$ primeira exposição de conjunto que consagra à transferência, Freud mostra que ela está ligada a protótipos, a imagos (principalmente à imago do pai, mas também à imago da mãe, do irmão, etc.): “o médico está inserido numa das séries psíquicas que o paciente já formou" (LAPLANCHE, 1974, p. 517)

A partir deste ponto podemos assinalar a outra faceta do mito que se apresenta no interior do tratamento: para além da vertente estruturante dos vínculos estabelecidos, encontra-se a particularidade das posições pressupostas em tais vínculos. A transferência, neste contexto, cada vez mais passará a responder por tal assimilação do mito à lógica da neurose.

Como vimos, desde a primeira menção ao mito de Édipo em 1897 estão presentes duas ideias centrais na teorização freudiana: (1) há neste mito uma referência de base sobre a forma pela qual o desejo recalcado teria se expressado na infância; (2) esta referência, encontrada na autoanálise de Freud e recorrentemente na sua experiência de escuta clínica, poderia ainda ser passível de generalização, universalização dos modos primitivos de relação. Tal entendimento do mito esperou por mais de dez anos até ter uma primeira definição conceitual sob a denominação de “complexo de Édipo", ou seja, até a descrição e articulação com o conjunto de noções e conceitos que servem à teoria da formação do psiquismo.

Um ponto central neste trajeto se encontra na quarta das conferências realizadas na Clark University sob o título Cinco lições de psicanálise (1910). Nesta apresentação, Freud, ao tratar da escolha primitiva de objeto pela criança, defende que 
ela primeiro toma ambos os genitores como objeto de seu desejo erótico. Mas não em qualquer configuração: o pai teria "em regra preferência pela filha, a mãe pelo filho: a criança reage desejando o lugar do pai se é menino, o da mãe se se trata da filha" (FREUD, 1910, p.44). Destas relações nascem sentimentos que operam por uma lógica dual, alternando entre positivos, ternos para com aqueles que realizam seu desejo, e negativos, hostis em relação aos que se opõe, permanecendo em seu caminho. A partir deste momento, tal dualidade estará - em especial sob a forma da ambivalência de sentimentos pressuposta pela indissociação das figuras que despertam amor e ódio atrelada à conceituação da transferência enquanto positiva ou negativa, uma vez que Freud explicitará, progressivamente, que na transferência a vivência fundamental que se repete é aquela que fora previamente estabelecida com os pais. No referido texto, ainda encontramos:

O complexo assim formado é destinado a pronta repressão, porém continua a agir do inconsciente com intensidade e persistência. Devemos declarar que suspeitamos represente ele, com seus derivados, o complexo nuclear de cada neurose, e nos predispusemos a encontrá-lo não menos ativo em outros campos da vida mental. O mito do rei Édipo que, tendo matado o pai, tomou a mãe por mulher, é uma manifestação pouco modificada do desejo infantil, contra o qual se levantam mais tarde, como repulsa, as barreiras do incesto. (FREUD, 1910, p.44)

Por complexo, Freud entende este conjunto organizado de lembranças, representações e afetos ligados às primeiras relações da criança com seus pais que, mais ou menos recalcado, permanece inconsciente, livre da influência do tempo. O "complexo nuclear de cada neurose", por esta via, denota o principio estruturante de toda neurose, que aspira à universalidade pelo padrão típico que lhe permite ser comparado com o mito de Édipo. No entanto, como salienta Garcia-Roza, a conceituação, nos primeiros escritos de Freud, do complexo de Édipo (termo que aparecerá em um artigo do mesmo ano da citação acima) expressa-o particularmente como "um conjunto ou uma estrutura ideativa que vai sinalizar a conduta da criança como, por exemplo, nas suas futuras escolhas de objeto" (GARCIA-ROZA, 1983, 
p.218). Enquanto complexo ideativo, o complexo de Édipo não funcionaria como uma “"estrutura estruturante' externa ao indivíduo e que o determina enquanto tal” (Ibidem, p.219). Ou seja, nesta primeira enunciação do complexo de Édipo freudiano, não há uma clara distinção entre seu valor estruturante na constituição do sujeito, por um lado, e a configuração particular na qual esta estrutura se atualiza do drama individual de cada sujeito. Deste modo, não seria ainda possível distinguir o que em sua aparição constitui uma necessidade e o que é dependente da vivência concreta do sujeito no seio de seus primeiros vínculos familiares.

Não há na escrita freudiana uma exposição sistemática sobre o complexo de Édipo, a despeito de sua centralidade no conjunto da teoria psicanalítica da constituição do sujeito. Não buscaremos refazer este percurso, no entanto, salientamos acerca do complexo de Édipo três pontos fundamentais: (1) Freud encontra no mito de Édipo, tal qual representada pela versão da tragédia de Sófocles, Édipo Rei, um modelo que permitiria conceber um traço universal do homem, um conflito psíquico presente na vida de todo sujeito. No entanto, é importante salientar que o complexo de Édipo não se restringe aos detalhes do mito. Em outros termos, ele não tem suas particularidades justapostas aos traços presentes no mito que lhe serviu de base para sua conceituação (Cf. MEZAN, 1989); (2) em segundo lugar, devemos ressaltar o valor crescente de tal conceituação frente à atualização das relações postas em jogo na transferência, ou seja, enquanto "complexo nuclear das neuroses", o complexo de Édipo servirá para dar contornos precisos à configuração da versão do mito individual realizado no setting clínico; (3) e, por último, a centralidade de tal complexo para a teoria da formação do psiquismo em Freud necessitará ainda de alguns desenvolvimentos adicionais - como sua articulação com a teoria da identificação, com o narcisismo, com a fase fálica do desenvolvimento libidinal e com o complexo de castração - que justifique a prevalência de sua função de "estrutura estruturante" universal frente às mais heteróclitas situações a que possam ser submetidos os sujeitos desde os mais tenros anos.

A inscrição do mito, enquanto produtor de significações, no pensamento freudiano traz consigo, portanto, uma exigência de método para a fundamentação sobre uma clínica que se queira científica, a saber, a possibilidade de generalização, universalização de seus postulados para uma ordem da experiência que se mostrasse presente em todos os homens. O recurso ao mito de Édipo, e posteriormente Totem e Tabu, entre outros, demonstram a necessidade de tal universal se faça em um campo 
simbólico, marcado pela indissociável inscrição do sujeito em suas produções sejam elas patológicas, ou não. Mais que narrativas unívocas, preditivas, sobre os destinos do homem, elas tratam das coordenadas simbólicas que condicionam a vivência cotidiana e sintomática do neurótico, e prestam sua estrutura para a formalização da clínica psicanalítica. Veremos adiante, especialmente quando tratarmos da releitura lacaniana das teses freudianas, como o mito em sua lógica adquire papel central para analisar a inscrição de um sujeito no sistema sócio-simbólico da linguagem.

Vimos, portanto, como a disciplina antropológica surge como um dos recursos da teorização freudiana desde seus princípios, em especial, como base para a fundamentação de um modelo de clínica, em especial dos princípios diagnósticos e terapêuticos, no qual a palavra assume um papel primordial. Em um segundo momento, vimos como, esta trilha se não determina em última instância, ao menos prepara o terreno para a entrada em cena da narrativa edipiana, em seu valor mítico, como um princípio de universalização da experiência analítica. Das consequências extraídas deste fato para uma parcela da teoria psicanalítica, encontramos a remissão à noção de mito como um centro articulador das relações entre as determinações inconscientes de um sujeito e o lógica significante no interior da qual o discurso concreto que cerca suas origens.

No processo de assimilação e reconhecimento do mito, como um operador de síntese entre o campo do coletivo e do individual, Freud conceberá seu próprio mito em Totem e Tabu, obra incontornável no diálogo entre psicanálise e antropologia. Encontramos aí, a um só tempo, a expressão máxima, tanto do valor do mito para a expressão de fenômenos clínicos, apreendidos cotidianamente em sua prática analítica, como do valor da antropologia para a inscrição de sua teoria em um universalidade que transcenderia as fronteiras históricas e geográficas: Totem e Tabu abre um campo franco de trocas entre as duas disciplinas, sustentando correlações fundamentais entre ambas (FOUCAULT, 1966, p.526).

Analisaremos a seguir quais são suas principais teses, passando então à recepção da primeira geração de antropólogos, assim como os efeitos deste período inaugural para a inscrição da lógica mítica como um ponto fundante de intercâmbio entre ambas as disciplinas. 


\section{CAPÍTULO 2}

Como dissemos ao início do capítulo anterior, uma das pretensões freudianas com a publicação dos quatro ensaios que futuramente viriam a compor Totem e Tabu, era a de aproximar e estimular uma cooperação entre os estudiosos da antropologia social, filologia e folclore, e aqueles que se dedicavam à psicanálise (FREUD, 1913 [1912-13], p.17). Com tal meta em vista, Freud realizou aquilo que denominou como sua "primeira tentativa de aplicar o ponto de vista e as descobertas da psicanálise alguns problemas não solucionados da psicologia social" (Ibidem, p.18). Com a menção à Völkerpsychologie - literalmente "psicologia dos povos", cuja principal referência da época era Wilheim Wundt - Freud explicita a intenção de demonstrar o valor do método e dos postulados psicanalíticos à articulação entre a análise de fatos individuais e de fatos sociais. A noção de psicanálise aplicada encontrou nos ensaios um novo patamar, haja vista, não apenas a grandiosidade do empreendimento freudiano, como o fato dos artigos terem sido publicados nos números iniciais da revista Imago, revista criada em 1912 por Freud, Hanns Sachs e Otto Rank, e que tinha como subtítulo: Revista para a aplicação da psicanálise às ciências do espírito.

Entretanto, mais que aplicar a psicanálise a um campo alheio, ela funda todo um campo de comunicações, como sustenta Michel Foucault:

Desde Totem e Tabu, a instauração de um campo que lhes seria comum, a possibilidade de um discurso que poderia ir de uma à outra sem descontinuidade, a dupla articulação da história dos indivíduos com o inconsciente das culturas e da historicidade destas com o inconsciente dos indivíduos abrem, sem duvida, os problemas mais gerais que se podem levantar a proposito do homem (FOUCAULT, 1966, p.526)

Os esforços de Freud, neste contexto, não ficaram indiferentes aos etnólogos desde sua emergência. Podemos mesmo dizer que este marco princeps do franco diálogo entre os dois campos estabeleceu não somente o tom, como o compasso e a melodia dos encontros e desencontros entre as duas disciplinas por pelo menos quarenta anos. Durante esse período, portanto, a interlocução entre a obra freudiana e a 
antropologia social orbitou, especialmente, por modulações de leitura das bases e teses propostas em Totem e Tabu.

O presente capítulo visa explanar o modo como a antropologia do início do século XX recebeu a obra freudiana. A virada do século marca na disciplina antropológica um momento de rupturas com as escolas evolucionistas e difusionistas que iniciou, consequentemente, um período de formação das bases epistêmicas e metodológicas da denominada antropologia moderna. Se por um lado, temos a oportunidade de estabelecer um mapeamento dos embates e críticas sobre as premissas de método e hipóteses apresentadas pela psicanálise, em geral, e em Totem e Tabu, em particular, por outro, nos será possível apreender o solo no qual emerge uma antropologia como a de Lévi-Strauss, cujo diálogo com a psicanálise e os avanços na análise dos mitos foram sem precedentes na história da disciplina.

\section{A torção da relação de Freud com a antropologia: Totem $e$ Tabu e a busca da universalidade do drama edípico}

Em Totem e Tabu, Freud tem como objetivo primário dotar de estatuto universal o Édipo: eis onde entra a antropologia social enquanto um campo do saber que possibilita um "princípio de generalização a partir de levantamentos e inventários [de formas de expressão culturais] que procura tornar completos" (LÉVI-STRAUSS, 1960, p.52). As fontes de Freud são vastas, entretanto suas referências são compostas basicamente por representantes da antropologia do fim do século XIX, permeada por uma ideologia evolucionista, como podemos observar pela estatística fornecida pelo índex alemão de nomes próprios citados por Freud: considerando sua obra toda, encontramos 2 citações a Lewis Morgan (1818-1881), 6 a Edward Tylor (1832-1917), 13 a William Robertson Smith (1846-1894) e 31 a James Frazer (1854-1941), sendo 27 apenas na obra que ora tratamos (Cf. DELRIEU, 2004, p.30).

Como afirma Sándor Ferenczi, a escrita de Totem e Tabu participa de um momento de virada na teoria freudiana, que passou a arriscar ir além da análise da “ciência do desenvolvimento psíquico pós-natal” (FÉRENCZI, 1920, p.205), em prol das especificações dos fatores considerados "inatos" ou constitucionais na etiologia da neurose. $\mathrm{O}$ cerne do texto freudiano se encontra na ancoragem histórica das condições 
para a emergência do complexo de Édipo enquanto coetâneas, lógica e cronologicamente, da origem da própria cultura, nas palavras de Roudinesco:

Freud ansiava dar uma explicação global da origem das sociedades e da religião a partir dos dados da psicanálise, ou, dito de outra maneira, dando um fundamento histórico ao mito de Édipo e à proibição do incesto e mostrando que a história individual de cada sujeito não é mais que a repetição da própria história humana. (ROUDINESCO, 1997, p.757)

No primeiro ensaio, intitulado Horror ao Incesto, Freud realiza um estudo descritivo da analogia com os neuróticos na forma do horror e das medidas defensivas tomadas pelos povos selvagens frente ao incesto, enquanto relação endogâmica entre clãs, estes aqui definidos como grupos de parentesco articulados em torno de um mesmo totem. A demonstração da relação essencial, interna entre totemismo e exogamia, virá nos ensaios seguintes. No entanto, o projeto já anunciado no subtítulo do livro - Alguns pontos de concordância entre a vida mental dos selvagens e dos neuróticos - tem um tratamento preliminar no ensaio, onde há a aposta que a “comparação entre a psicologia dos povos primitivos e a psicologia dos neuróticos está destinada a encontrar numerosos ponto de concordância e assim lançar nova luz sobre os fatos de ambas as disciplinas" (FREUD, 1913, p.20).

Em seu fechamento, Freud conclui que procurou neste ensaio apenas demonstrar como o horror ao incesto apresentado pelos selvagens, lido através das contribuições psicanalíticas, pode ser considerado como uma "característica fundamentalmente infantil, e que revela uma notável concordância com a vida mental dos neuróticos" (FREUD, 1913, p.36) Tanto o selvagem, quanto o neurótico teriam uma relação objetal marcada por um intenso conflito diante de desejos incestuosos, sendo que o primeiro os vive como um perigo imediato, enquanto o neurótico, os teria como base de seu "complexo nuclear das neuroses". Este último, enquanto um conjunto sistemático do conflito infantil, motivado pela proibição de um desejo incestuoso, inscreve um ponto de fixação da libido que serviria de base homóloga para a dinâmica das atitudes defensivas dos neuróticos e dos selvagens.

Como aponta Roudinesco (1997), a escolha terminológica de Freud por selvagem (Wilder) ou primitivo (Primitiv), estava condicionada à forma como a 
antropologia evolucionista concebia seus nativos. Na história da formação desta disciplina, a aplicação inconsequente de um ideal evolucionista na construção de uma história progressista, teve como decorrência a estigmatização de povos não-ocidentais como portadores de dotes intelectuais, racionais e qualquer outro que delimite o campo do humano, qualitativamente inferiores aos presentes no homem-adulto-branco-cristão (RIVIÈRE, 1995, p.35). Não é preciso entrar em detalhes sobre a imensidão de categorias que ficaram fora de tal posição "privilegiada", no entanto, o fato é que os povos selvagens foram considerados como dotados de um pensamento pré-lógico, préempírico e místico (Cf. LÉVY-BRUHL, 1932), ainda estagnados no que seriam os primórdios da história humana.

Ao estabelecer uma relação de homologia entre a psicologia das crianças, dos neuróticos e dos selvagens, Freud deixou seu empreendimento aberto a inúmeras críticas, mesmo ciente de que as receberia (FREUD, 1913, p.22; p.186). Estas vão desde a acusação de que sustentaria um discurso eurocêntrico sobre os nativos, até o rechaço da comunidade antropológica às hipóteses daí derivadas (Cf. PULMAN, 2004). Entretanto, temos aqui a posição de que, se Freud importara tal terminologia, com todos os preconceitos evolucionistas embutidos, ele não os tomou como central para sua argumentação. Desde seus primeiros escritos, Freud considera um fato que a distinção entre o estado patológico e o normal não é de estrutura, mas de gradação, uma diferença que opera na esfera quantitativa. Portanto, quer falemos de um selvagem, quer de um neurótico, a premissa inicial é que sua constituição psíquica é homóloga à psicologia imputada aos indivíduos normais. Freud, deste modo, mesmo tratando dos povos selvagens enquanto "primitivos", rompe com a vertente evolucionista ao reconhecer em suas produções culturais e comportamentais um estatuto de racionalidade, de elaboração simbólica, assim como não lhes nega a história pressuposta em suas instituições (FREUD, 1913, p.23). Veremos adiante como a noção análoga de "originário" (Ur, em alemão), "primevo" serve a Freud para uma ancoragem histórica e social do complexo de Édipo.

O segundo capítulo, Tabu e ambivalência emocional, dando continuidade à estratégia do primeiro, investiga a relação homóloga no selvagem e no neurótico da articulação entre o tabu e a ambivalência. $O$ tabu - palavra polinésia que designa ao mesmo tempo "sagrado", "impuro", "perigoso" e "misterioso" - teria uma série de paralelos com os sintomas obsessivos, sendo de especial interesse para o estudo da 
“origem obscura do nosso próprio imperativo categórico" (FREUD, 1913, p.42). Dentre estes pontos de concordância, encontramos os seguintes: “(1) o fato de faltar às proibições qualquer motivo atribuível; (2) o fato de serem mantidas por uma necessidade interna; (3) o fato de serem facilmente deslocáveis e de haver um risco de infecção proveniente do proibido; e (4) o fato de criarem injunções para a realização de atos cerimoniais.” (Ibidem, p.49). A finalidade do ensaio é marcar que tanto o tabu, quanto os sintomas obsessivos não apresentam apenas uma semelhança de forma, mas que teriam a natureza comum de provir de um conflito entre desejos opostos, haja vista a presença central de sentimentos ambivalentes tanto nos tabus, quanto nos sintomas, atos, medidas defensivas e ordens obsessivas. Neste e no próximo ensaio, Freud começa a traçar uma proximidade entre o selvagem e o neurótico que, para além de uma semelhança estrutural de conflito, poderiam indicar uma transmissão histórica do conflito de um para outro. Vejamos o próximo capítulo antes de perscrutar tal questão.

O terceiro ensaio, intitulado Animismo, magia e a onipotência de pensamentos, objetiva estabelecer mais um paralelo entre a atitude mental dos neuróticos, selvagens e crianças, a saber, aquele que diz respeito à supervalorização comum de seus atos psíquicos. Acompanhemos seu raciocínio: o sistema de pensamento animista, enquanto Weltanschauung dos povos selvagens, tem como característica principal a apreensão de todo o universo como uma unidade isolada, coerente, a partir de um ponto de vista único, projetado para o mundo externo (Cf. TYLOR, 1891, p.477). Para Freud, acompanhando um tema comteano clássico, esta seria a primeira das três grandes representações do universo, composta da visão animista (ou mitológica), da religiosa e da científica. Três momentos do desenvolvimento da visão humana de universo que assinalam três destinos para a onipotência de pensamento que serão centrais para seu argumento.

Feitas tais colocações, Freud partirá para mostrar como a magia - sistema técnico do animismo, como definido por Mauss (1904) - procede por associações semelhantes às encontradas pela psicanálise nas formações do inconsciente: relacionando seus termos essencialmente a partir de ligações de semelhança - presentes, e.g., no processo de condensação dos sonhos e nas efígies usadas nos feitiços - e ligações de contiguidade - tanto no deslocamento, quanto na atenção às partes do corpo, nomes e outros termos que remetam por ligação metonímica uma dada pessoa no momento da magia. No entanto, esta proximidade associativa não explicaria a 
verdadeira essência da magia, qual princípio que a moveria. Freud responde: esta é motivada pela crença exacerbada no poder do desejo, das ideias, ou seja na onipotência de pensamentos. Ora, constata Freud, este traço é encontrado em certo momento do desenvolvimento libidinal das crianças, permitindo uma relação entre as atitudes psíquicas dos selvagens e das crianças. O que poderia ser visto como uma afirmação do infantilismo intelectual do pensamento primitivo é logo retificado com a asserção de que tal atitude mental também se encontra em homens altamente inteligentes, como é o caso de seu paciente que sofria de ideias obsessivas e ficou conhecido como o Homem dos Ratos (FREUD, 1909).

A descrição da neurose como um sistema de superstições, crenças e atos que tomam a supervalorização do pensamento, ou seja, a indissociabilidade entre pensar e agir, como motor de ação, a aproxima do sistema animista. Tanto uma como a outra parece ter seu princípio de funcionalidade definida por uma hipercatexia do Eu, próprio da fase narcisista do desenvolvimento libidinal, fase esta ainda pouco desenvolvida na obra freudiana quando da escrita do ensaio. Freud então propõe a seguinte hipótese:

Se podemos considerar a existência da onipotência de pensamentos entre os povos primitivos como uma prova em favor do narcisismo, somos incentivados a fazer uma comparação entre as fases do desenvolvimento da visão humana do universo e as fases do desenvolvimento libidinal do indivíduo. A fase animista corresponderia à narcisista, tanto cronologicamente quanto em seu conteúdo; a fase religiosa corresponderia à fase da escolha de objeto, cuja característica é a ligação da criança com os pais; enquanto que a fase científica encontraria uma contrapartida exata na fase em que o indivíduo alcança a maturidade, renuncia ao princípio de prazer, ajusta-se à realidade e volta-se para o mundo externo em busca do objeto de seus desejos. (FREUD, 1913, p.113)

Realizado o paralelo entre o desenvolvimento libidinal individual e a evolução na história da visão de universo, Freud parte, no último capítulo, para a investida em favor da reconstrução histórico-lógica dos fatores que estavam em jogo na determinação mútua dos dois níveis de desenvolvimento, tanto ontogênico, individual, quanto filogênico, da espécie. Esta reconstrução passa pela hipótese da recapitulação, ou seja, 
que eventos determinantes na história da evolução filogênica, retornariam como pontos críticos no desenvolvimento do indivíduo, como podemos ver no próprio título do quarto ensaio: $O$ retorno do totemismo na infância. Talvez o mais ousado da obra de Freud, este parte para a defesa da hipótese de que todos os paralelos entre os selvagens, neuróticos e crianças, apontados anteriormente, estariam ancorados nas condições próprias do complexo de Édipo. Mais ainda: este que poderia ser remetido a um evento primordial e fundador das principais instituições da sociedade e, no limite, de sua própria origem. Eis a hipótese da Horda Primeva, tão famosa quanto alvo de severas críticas desde seu surgimento.

\subsection{A Horda Primeva: um mito histórico}

Retomando a instituição totêmica, Freud concebe duas proposições como as principais de sua constituição enquanto religião e sistema social: não matar seu o animal que representa seu totem e não ter relações sexuais com pessoas que pertençam ao mesmo clã. Freud passa a investigar se estas duas injunções teriam um fundo comum, buscando saber se sua relação é contingencial ou se procede de algum tipo de necessidade lógica. A regulação social destas duas leis primordiais do sistema totêmico partem, segundo a lógica psicanalítica, de dois impulsos que, por algum motivo, precisaram ser interditos. Uma chave encontrada por Freud para a contribuição da psicanálise ao esclarecimento do sistema totêmico é dada por uma particularidade do sintoma fóbico infantil. Apelando aos conhecidos casos do pequeno Hans (FREUD, 1909), que tinha fobia de cavalos, e de Árpad (FÉRENCZI, 1913), o menino que se identificou com um galo, Freud pode conceber que os animais totêmicos, assim como estes "totens" presentes no temor fóbico, seriam um substituto, por algum mecanismo de deslocamento de sentido, do pai. Esta asserção, leva Freud à afirmação da origem comum das instituições do totemismo e da exogamia, enquanto produto das condições do complexo de Édipo (FREUD, 1912-3, p.159). Freud poderia ter se detido neste ponto, na configuração edipiana comum dos conflitos individuais e dos conflitos coletivos, no entanto, necessitava para dar à sua hipótese um lastro científico, tal qual entendido na época, de um fato que justificasse a origem de tal estrutura comum.

Valendo-se - entre uma miríade de referências - da hipótese darwiniana de que talvez o homem tenha vivido em seus primórdios como os grandes primatas, ou seja, em 
pequenas hordas onde um único macho despótico detém o domínio sobre um conjunto de fêmeas; da hipótese de Robertson-Smith sobre a relevância da refeição totêmica e da teoria de Atkinson da origem da exogamia para os jovens exilados, Freud formulou o que chamou de um mito científico, ou seja, os determinantes históricos que constituíram o sistema de representações e afetos atualizado no complexo de Édipo.

A hipótese da horda, vastamente explorada, propõe, em linhas gerais, a seguinte narrativa: em um tempo primitivo, os seres humanos viviam em pequenos grupos formados por muitas fêmeas e um único macho que dominava a todas elas, além de se livrar dos machos mais novos, incluindo seus filhos. Certo dia, estes filhos renegados se juntam e promovem uma rebelião contra o pai, derrotando-o e devorandoo juntos. Com o intuito de viver pacificamente, o novo clã fraterno, renuncia às fêmeas, instituindo o princípio da exogamia. Entretanto, "a atitude emocional ambivalente dos filhos para com o pai permaneceu em vigor durante todo o desenvolvimento posterior. Um animal específico foi colocado em lugar do pai, como totem" (FREUD, 1939, p.155). O deslocamento da relação do pai, para o totem, fez com que, por um lado, os irmãos proibissem sua morte e consumo, mas por outro, permitissem, ante um ritual coletivo, o despedaçamento e consumo. Como repetição da morte do pai, ou melhor, reencenação do fato que fundou a "ordem social, as leis morais e a religião" (Ibidem), tal ritual reafirmava o laço entre os irmãos/comensais.

Sem a pretensão de aqui analisar tal narrativa em seus pormenores, antes voltemos nossa atenção ao seu método de construção. Três pontos, que trataremos no decorrer do capitulo, merecem atenção aqui: o primeiro é a insistência na necessidade de um ato, por essência historicamente determinado, que fundasse a sociedade, ato que teria como decorrência a transmissão das suas consequências para as gerações futuras. O segundo ponto é existência de uma série de críticas provindas da etnologia às fontes $\mathrm{e}$ consequências extraídas daí para a argumentação de Freud. Neste percurso, traçaremos um breve panorama das recepções da obra freudiana em seu conjunto pelos principais expoentes do pensamento da etnologia no início do século XX. O terceiro e último ponto diz respeito à lógica mítica aí pressuposta, que marcará a releitura de Lévi-Strauss do clássico freudiano.

Acerca do primeiro ponto, embasado na tese evolucionista da recapitulação cujo postulado básico é o de que a ontogênese reproduziria em seus pormenores os caminhos traçados pela filogênese - Freud compreende que a constituição sexual de um 
indivíduo, seu desenvolvimento libidinal, estaria marcado pela transmissão de características psíquicas e afetivas, provindas desde os princípios da cultura - no caso em questão, a transmissão seria do sentimento de culpa pela morte do pai da horda, posteriormente imortalizado na figura do totem. Esta leitura freudiana é tradicionalmente são imputada à influência das proposições de Lamarck, nas quais encontramos o mote de que as características físicas, fenotípicas adquiridas em vida por um dado indivíduo poderiam ser transmitidas para seus descendentes. Entretanto, como sustenta Ritvo (1990), a leitura de Freud responde pela teoria da evolução de origem darwiniana, dado que ela que admitiria em seus postulados "a transmissão de certas 'vontades' hereditariamente” (DUNKER, 2013, p.140). Mesmo contestado há muito quando da escrita de Totem e Tabu, este ponto de vista acompanhou Freud até o fim da vida. No entanto, mais do que uma simples insistência em uma teoria já refutada, ela tem uma posição especial na economia conceitual da obra freudiana.

No capítulo anterior, analisamos como o diálogo estabelecido entre Freud e as ciências sociais esteve intimamente ligado à concepção de um sujeito determinado por uma instância psicossocial sistematizável por regras fundamentais, ou estruturada como uma linguagem como dirá Lacan futuramente (Cf. LACAN, 1953a). No interior da emergência do conceito de inconsciente como um dispositivo fundamental para a formulação de uma teoria da constituição do psiquismo, o mito aparece como uma das noções privilegiadas para a edificação da psicanálise, seja por se configurar como uma narrativa partilhada determinante para os destinos da vivência de cada homem, seja por sua onipresença no âmbito social e individual.

A hipótese da horda primeva, enquanto mito de valor antropológico, é considerada por Freud como uma construção que teria, a um só tempo, um valor universal, atemporal, e um valor histórico, portanto, de um fato, se não acessível à constatação, ao menos plausível e necessário. É neste contexto que se insere o caráter imprescindível das teorias derivadas de uma ideologia evolucionista (antropologia, história, arqueologia, teorias da hominização). Antes de assimilar o programa teleológico, etnocêntrico, da história como evolução progressista, Freud trata a inscrição histórica como a possibilidade de, por um lado, dotar sua teoria de um estatuto supostamente "científico", embasado em "fatos", mesmo que pré-históricos, e de outro, de responder pelo caráter recorrente, típico das formações do "complexo nuclear das neuroses" - ou seja, de ler a configuração edipiana, universal, como proveniente de 
experiências arcaicas, constitutivas do homem. Analogamente, veremos como o uso do recurso histórico para a explicitação dos eventos recorrentes, pretensamente universais, fora realizado por um dos maiores críticos das teses evolucionistas, a saber, Franz Boas.

Por tal realização, as teses de Totem e Tabu são consideradas como uma das principais construções míticas presentes da teorização freudiana, como nas palavras de Joel Dör ela estabelecer o mito "sem o qual não poderíamos compreender a teoria do pai em psicanálise, já que é dele que recebe sua substância” (DÖR, 1989, p.19). Seu valor para a teoria psicanalítica, enquanto índice para uma teoria da filiação, da articulação entre as dimensões do sexual e da morte, não se inclui diretamente como um ponto de mediação ao diálogo entre as disciplinas. Entretanto, mesmo duramente retaliada pela antropologia da época, principalmente pela imperícia na escolha das fontes, Totem $e$ Tabu marcaria uma virada na posição do mito e da antropologia no diálogo com a psicanálise.

Encontramos aí o mito respondendo não somente pela posição de um objeto especial, ou uma via régia a uma realidade mais fundamental, ele também entraria como um princípio de método, em analogia com o fenômeno aqui pesquisado. Ao apostar na construção de um "mito histórico", Freud intenta não apenas o relato de fato histórico inacessível, algo por si só dificultoso ao método historiográfico, mas a reconstrução de uma narrativa que tem um estatuto de verdade eficaz para a totalidade dos homens, portanto, um mito universal a ser reconstruído, recontado a partir de muitas versões apreendidas seja pela experiência clínica, seja pela análise dos dados de seus etnógrafos contemporâneos. A lógica de uma estrutura que se projeta em perspectiva e estabelece uma atualização contínua de sua forma é justamente a lógica temporal pressuposta no mito. O valor de mito de Totem e Tabu, portanto, está certamente na sua constante, porque estrutural, eficácia frente ao drama neurótico da questão do pai.

O reconhecimento do valor metodológico da noção de mito - que como vimos está presente na obra freudiana desde suas primeiras menções à lenda de Édipo e aos "mitos endopsíquicos" - aparece em sua expressão máxima em Totem e Tabu. Ao considera-lo por seu caráter necessário e constitutivo, o psicanalista vienense permitese, ao mesmo tempo em que formula uma hipótese dos eventos fundantes da cultura, construir uma versão de um mito que seria reeditado cotidianamente, em versões fragmentárias, na vida dos homens. Antes de simplesmente recolher e procurar por versões, Freud insere na teoria psicanalítica a possibilidade de se construir mitos, sem 
perder seu "valor científico". Eis o giro propiciado pela publicação de Totem e Tabu: doravante, mais que uma atividade de prática e pesquisa clínica, a psicanálise colocavase como uma disciplina que poderia contribuir decisivamente para a leitura da dimensão universal da humanidade, para o desenvolvimento do "discurso científico o homem", a antropologia. Passo esse que, "em uma mescla de ousadia e prudência” (GAY, 1988, p.304), inscreve em um lugar central, constitutivo a dimensão do mito!

Passemos à reverberação de Totem e Tabu no milieu antropológico e como ele serviu de meio para a rearticulação da psicanálise com a clínica, agora em um ambiente eminentemente situado no interior da disciplina etnológica.

\section{As críticas a Totem e Tabu e as esferas de aproximação entre psicanálise e antropologia no começo do século $\mathrm{XX}$}

Entre os destinos encontrados pela aproximação entre a antropologia social e a psicanálise tal qual proposto em Totem e Tabu - tomando como mote central a semelhança entre as instituições totêmicas e os sintomas neuróticos, até a pretensa demonstração da universalidade do complexo de Édipo em um meio limítrofe entre as duas disciplinas - destacaremos, com vistas ao objetivo do presente estudo, o modo como quatro grandes nomes da etnologia receberam a obra psicanalítica: o antropólogo polonês Bronislaw Malinowski (1884 - 1942), o linguista e antropólogo Franz Boas (1858 - 1942), o psiquiatra e etnólogo W. H. R. Rivers $(1864$ - 1922) e por fim, o antropólogo Marcel Mauss (1872 - 1950). Se, por um lado, é onipresente o comentário crítico sobre a fundamentação das teses freudianas no campo empírico e epistemológico da antropologia, por outro, a inscrição do debate com a psicanálise no projeto teórico de cada um marca os diferentes compassos nos quais cada um formou seu recorte conceitual. Nesta pluralidade, buscaremos situar o meio no qual surgiu aquele que não apenas redefiniu as bases do diálogo com a psicanálise, como de toda disciplina antropológica, Claude Lévi-Strauss.

Grande foi o impacto do surgimento da tradução inglesa de Totem e Tabu no início da década de vinte. A antropologia social britânica mostrava-se um expoente na edificação da disciplina e tinha a particularidade de seus programas acadêmicos articularem em suas ementas temas relacionados à antropologia, à sociologia e à psicologia (LAPLANTINE, 1987, p.77). Às vésperas das críticas de Malinowski e do 
"surgimento deste, no discurso antropológico, como o herói mítico do método antropológico" (STOCKING, 1983 apud PULMAN, 2004, p.125), encontramos duas importantes críticas às teses de Freud: a primeira de Robert Marett e a segunda, de maior impacto, de Alfred Kroeber. Marett, no prefácio à edição inglesa de 1920, tomava a contribuição da psicanálise à antropologia como praticamente nula, posto que sua hipótese genética das instituições totêmicas serviam como uma "história pura" (Cf. GAY, 1988, p. 304) que pouco ou nada acrescentava às análises e exigências do contexto atual encontrado no campo antropológico. Crítica que Freud recebera bem, com certo "divertimento" (Ibidem), posto que discordava do papel secundário cedido à história na análise antropológica, mas que já indicava certo distanciamento entre a produção antropológica contemporânea a Totem e Tabu, o os postulados freudiano aí encontrados.

Entretanto, a segunda crítica, de Kroeber, foi bem mais incisiva em seus termos. Elencando mais de doze itens de brechas no texto freudiano, Kroeber faz a reprimenda geral de que a escolha de Freud de seus interlocutores na antropologia social não representava o atual estado disciplina, sendo que muitas das teorias utilizadas já haviam sido contundentemente refutadas. Dentre as principais críticas encontram-se a de que Freud teria utilizado as ideias Darwin e Aktinson, sobre o agrupamento primitivo das Hordas, como teses, enquanto seus postulados são apenas hipotéticos e encontram diversos fenômenos que contestam sua validade (KROEBER, 1920, p. 50; MALINOWSKI, 1927); a crítica de generalização da tese de Robertson-Smith sobre o sacrifício ritual que só seria válida para as culturas Mediterrâneas do século II A.C. e suas descendentes (KROEBER, 1920, p.51), particularidade provada pelo próprio Frazer. (Cf. ELIADE, 1962); e, por fim, de afirmação de que a exogamia e abstenção do totem seriam as injunções primárias do sistema totêmico, sem correlato nos dados coletados de campo (KROEBER, 1920, p. 52), portanto, que poderiam ser refutadas, segundo os critérios científicos próprios à etnologia.

A preocupação de Kroeber para a fundamentação da articulação entre a psicanálise e etnologia, estava menos relacionada a uma pretensa impossibilidade de diálogo que ao esforço da última de se constituir como disciplina. É explicita a recomendação de se atentar para o fato de que a Etnologia não estava ali representada, posto que nem Frazer, nem Tylor poderiam ser considerados etnólogos: realizavam antes uma "psicologização generalizada dos dados etnológicos para a composição de 
suas teses" (KROEBER, 1920, p 55). Esta última crítica reverbera diretamente com o papel de Malinowski na época, vejamos como o lugar ocupado por sua obra neste debate.

\subsection{Malinowski e a querela da universalidade do Édipo: questões de método}

Como aponta Laplantine (1988, p.60), a partir da publicação de Os Argonautas do Pacífico Ocidental, em 1922, o antropólogo polonês dominou a cena antropológica por mais de 20 anos. Isto se deveu pela radicalização no fazer antropológico efetuado pelo seu método aí proposto: Malinowski não fez nada menos do que elevar o estatuto da experiência de campo à condição inerente e necessária da pesquisa em antropologia. Sob sua pena e de Boas, a antropologia viveu o período áureo do método etnográfico (VIVEIROS DE CASTRO, 1996, p.299). Esta modificação pode-se dizer que foi um dos efeitos às críticas dirigidas às correntes evolucionistas, conjecturais, representadas pelos antropólogos do fim do século XIX, entre os quais se afiguram como grandes expoentes Spencer, Gillen, Robertson-Smith, Lang, Reinach e James Frazer, este ostensivamente utilizado por Freud como Vademecum (KROEBER, 1920, p. 52).

Malinowski propõe que antes de se iniciar uma série de comparações a partir de relatos de centenas de informantes em campo, reconstruindo nesta experiência pouco mais que os preconceitos ocidentais sobre o que seria daí apreensível, que o antropólogo vá a campo e se reconstrua um modo de pensar "outro" a partir da totalidade de cada sociedade. O “empirismo obsessivo" (LEACH, 1957, p.120) de Malinowski funda a antropologia como disciplina da alteridade. O projeto maior de sua obra, portanto, inspira uma mudança não apenas na leitura dos dados, como da atitude do próprio etnógrafo, em suas palavras:

"Estamos hoje muito longe da afirmação feita há muitos anos por uma célebre autoridade que, ao responder uma pergunta sobre as maneiras e os costumes dos nativos, afirmou: 'Nenhum costume, maneiras horríveis'. Bem diversa é a posição do etnógrafo moderno, que, armado com seus quadros de termos de parentesco, gráficos genealógicos, mapas, planos e diagramas, prova a existência de uma vasta organização nativa, demonstra a constituição da tribo, do clã e da família e 
apresenta-nos um nativo sujeito a um código de comportamento e de boas maneiras tão rigoroso que, em comparação, a vida nas cortes de Versalhes e do Escurial parece bastante informal. (Cf. MALINOWSKI, 1922, p.8).

No interior de sua crítica, Malinowski verifica a necessidade conceitual da operação de uma distinção em todo campo da antropologia entre observação e descrição objetiva dos fatos de um lado, especulação e construções puramente teóricas, de outro (PULMAN, 2004, p.128), segmentando, dessa forma, o trabalho do etnólogo em duas categorias:

““'Observações de primeira-mão’ (1911a, p.383) que realizam 'uma descrição tão objetiva e completa possível dos fatos'(1910, p.139), e trabalhos de 'compiladores de segundamão' (1911b, p.27), em geral tomados por um 'ponto de vista dogmático'(1914, p.266)" (PULMAN, 2004, p.128).

A tentativa de distinção metodológica, para além da atitude do antropólogo e da fidedignidade de seus dados, reflete ainda uma mudança de perspectiva quanto à finalidade de sua ciência. Diferentemente de seu mestre, James Frazer, que reconhecia como questão norteadora principal "de que forma nossa sociedade chegou a ser o que é?”, de extração genética, portanto, Malinowski perscruta a investigação de uma sociedade dada em si, através de suas relações funcionais. Nas palavras de Da Matta:

A partir da teoria funcionalista, faz-se uma verdadeira revolução, criando-se um novo centro, que é sempre a sociedade em estudo pelo investigador. Deste modo, o ponto de referência não é mais a Europa e seus costumes, centro das racionalidades, mas a própria tribo, seguimento ou cultura em análise é que deve ser seu próprio centro. (DA MATTA, 1983, p.10)

O objetivo primordial da antropologia funcionalista de Malinowski era mostrar como tal ou qual comunidade exótica funcionava enquanto sistema social, seu interesse estava mais nas "diferenças entre as culturas que nas sua abrangente similaridade" (LEACH, 1970, p.2 apud DA MATTA, p.12). Se por um lado, encontramos nesta posição uma proximidade com a metodologia clínica psicanalítica, posto que ambas primam pelo valor diferencial, e não normativo, de suas construções, por outro; é neste 
mesmo solo que o antropólogo situará sua contraposição às abrangentes teorias apresentadas pela psicanálise.

A crítica de Malinowski à tese da universalidade do conflito edípico deriva desta problemática e é incisiva: a teoria do complexo de Édipo emergiu sem um referencial cultural consistente, e a tentativa ambiciosa de extrapolar seus resultados ao social não resiste às observações de campo. Em seus termos:

O complexo familiar nuclear é uma formação funcional, que depende da estrutura e da cultura de uma sociedade. É necessariamente determinado pela maneira em que as restrições sexuais são moldadas numa comunidade e pela maneira em que a autoridade é distribuída. Não posso conceber o complexo como causa primeira de tudo, como única fonte da cultura, da organização e da crença, como fons et origo de tudo (MALINOWSKI, 1927, p.124).

Ao longo dos vinte meses em que o antropólogo conviveu entre os trobriandeses, povo do noroeste da Nova Guiné, Malinowski percebeu como esta sociedade se regulava por um sistema de direito materno, ou matrilinear, fundada por um dado curioso: eles ignoravam em absoluto o papel da paternidade fisiológica, e "nenhum laço de parentesco ou relacionamento é suposto existir entre pai e filho, exceto aquele entre o marido da mãe e o filho da esposa" (MALINOWSKI, 1922, p. 55). Desta concepção, deriva um conjunto de relações bem distintos em sua materialidade da habitualmente descrita pelos psicanalistas: a ligação entre pai e filho é essencialmente marcada por um estreito laço afetivo, onde este se acerca de todas as demandas da criança. Por outro lado, é o tio materno - aquele que sustenta o lugar da autoridade em uma sociedade matrilinear - quem estabelece com a criança um vinculo distante, pautado na repressão e imposição de tarefas à criança de quem herdará a posição social. Portanto, o modelo de complexo extraído de tal contexto impõe graves à configuração mais presente na obra freudiana.

Ernst Jones, psicanalista britânico e presidente da IPA (Associação Psicanalítica Internacional), foi quem tomou a palavra para replicar, mais de uma vez, às críticas sofridas pela tese freudiana, em especial à de Malinowski. Em novembro de 1924, perante a Sociedade de Psicanálise Britânica (BPS) e o próprio Malinowski, Jones 
defendeu que a ignorância dos trobriandeses acerca do papel paterno na procriação era de fundo neurótico, tese que, segundo a ata da reunião, foi aceita sem ressalvas pelo antropólogo (BRYAN, 1925 apud PULMAN, 2004, p.137). No artigo desta exposição publicado no ano seguinte, Jones ainda afirma:

A irmã proibida e inconscientemente amada é apenas uma substituta da mãe, assim como o tio tem a mesma função com relação ao pai [...] o sistema matrilinear com seu complexo de avunculado, surge [...] como um modo de defesa contra as tendências edipianas primordiais (JONES, 1925, p. 128).

A anuência, ainda que preliminar, de Malinowski não deve ser entendida como o reconhecimento da ausência de divergências entre os dois e, consequentemente, o fim da querela. Ela marca uma importante distinção metodológica entre o fazer antropológico defendido por Malinowski e o alcance da interpretação psicanalítica dos dados etnográficos tal qual iniciado por Freud. Malinowski, acusado de operar no plano puramente descritivo (JONES, 1925, p. 127), lê a afirmação de Jones em um duplo viés: o primeiro, é que ela confirmaria sua tese de que o sistema matrilinear, por sua conjuntura social e econômica, exigiria uma outra configuração que não a apresenta classicamente pela representação de complexo de Édipo. A segunda via de leitura, leva Malinowski a reconhecer na amplitude interpretativa psicanalítica a ousada tese genética do deslocamento de sentimentos dos personagens de Édipo como uma defesa, tese que não rechaça, nem endossa sem que possa ter dados suficientes em campo para tal. Em seus termos:

Como antropólogo, compreendo mais especialmente que as teorias com relação aos selvagens, hipóteses sobre a origem das instituições humanas e teorias sobre a história da cultura, devem se basear em um extenso conhecimento sobre a vida primitiva, assim como dos aspectos conscientes ou inconscientes da mente humana. No fim das contas, nem o casamento grupal ou o totemismo, muito menos a evitação à sogra ou a magia acontecem no "inconsciente"; eles são fatos culturais e sociológicos sólidos, e para trata-los teoricamente com eles necessitamos de um tipo de experiência que não se 
pode obter em uma sala de consultório. (MALINOWSKI, 1927, p.xi)

A primeira via de leitura foi rebatida por Jones como derivada de uma incompreensão do escopo de ação da interpretação psicanalítica (LAPLANTINE, 1987, p.68). O segundo ponto, mais grave, teve a inserção de um novo teórico na querela: o antropólogo húngaro Géza Rohéim. Um dos primeiros antropólogos a aceitar o método psicanalítico como válido para sua prática etnográfica (ROHÉIM, 1948, p. 501), escreveu sobre a articulação entre os dois campos desde a publicação da coletânea Etnografia, em 1915. Rohéim foi o primeiro estudioso da psicanálise a realizar uma expedição de campo (MEZAN, 1985), entre os aborígenes australianos, financiada por Marie Bonaparte, para operar sua própria coleta de material e assim ter argumentos etnográficos da inconsistência da posição de Malinowski (ROHÉIM, 1948). A posição de Rohéim na antropologia, como expressa Eliade (1962), foi a de um guarda-costas do legado freudiano que sacava quando preciso um novo dado de etnográfico. Sintomática dos impasses encontrados no contato entre ambas as disciplinas, tal afirmação sintetiza o baixo reconhecimento daqueles que se dispunham a tal empreitada (DEVEREUX, 1953, p.420), como muitos outros, Rohéim foi recebido como muito psicanalista para os antropólogos e muito antropólogo para o debate da teoria psicanalítica.

Uma dupla tensão se encontra presente neste debate: a primeira é a da articulação entre o campo concreto da observação e o campo das generalizações e teorizações acerca das instituições fundamentais de uma sociedade; a segunda provém da dificuldade de se equacionar as análises extraídas de uma observação de coletividades e de expressões individuais. Em outros termos: como pensar em um nível de determinação que possa servir de princípio global de inteligibilidade para a leitura (semiologia) dos fenômenos clínicos e de campo? Esta discussão semiológica encontra de um lado, a psicanálise da década de 20 a usar a configuração da trama edípica como uma chave de leitura única e universal, sob o risco, das acusações de "abstração metafísica" e redução interpretativa. De outro lado, temos uma etnologia que prima pela prevalência do arranjo funcional coletivo sobre as manifestações individuais e pelo dado concreto e imediato, passível de abalar a inspiração dogmática de todo aquele que se volta para a inteligibilidade de costumes e instituições tão diferentes.

A ambas as disciplinas parece faltar um solo epistêmico que possibilite do lado da antropologia pensar em um nível de determinação estrutural dos fenômenos sociais 
para além de sua concretude imediata, e do lado da psicanálise uma configuração da trama edípica que não tenha na família nuclear seus personagens, mas antes posições simbólicas. Veremos tentativas de soluções a partir da obra de Boas e Mauss, mas em especial a partir da década de 50, com a emergência da teoria lévi-straussiana, cuja consideração pelo mito introduz os parâmetros pelos quais Lacan operará a releitura de Édipo.

Entretanto, a atitude funcionalista de Malinowski, com seu rechaço às análises históricas, à dimensão diacrônica da leitura dos fatos sociais - ponto de divergência com Boas e Rivers - reflete em uma interessante interpretação de Totem e Tabu, cuja ênfase recai em seu valor de representação de um evento próprio da ontogenia.

Freud entende a cultura como uma reação espontaneamente gerada de um crime e assim que a memória do crime, a repetição e atitude ambivalente sobreviveu em um "inconsciente coletivo". [...] Nossa absoluta incapacidade de aceitar esta hipótese, forçou-nos a examina-la mais de perto. Encontramos que o crime totêmico deve ser imaginado como um evento divisor entre a natureza e a cultura, como o momento de início cultural. Sem essa assunção a hipótese não tem sentido, permanece plena de inconsistências. Encontramos que na hipótese de Freud, assim como em várias outras especulações da origem da família, o principal engano é ignorar a diferença entre instinto e hábito, entre a reação biologicamente definida e o ajustamento cultural. Esta que levou nossa tarefa ao estudo da transformação dos laços familiares devido a passagem da natureza à cultura. (MALINOWSKI, 1927, p.215)

Ou seja, se Malinowski recusa o valor histórico da hipótese freudiana, ele não nega sua posição entre as representações próprias da lógica de inscrição do homem, enquanto determinado por seus instintos, no universo da cultura. Mesmo sendo a problemática da passagem da natureza à cultura plenamente reconhecida pelo antropólogo, essa recepção não implica, entretanto, na aceitação do caráter necessário do mito da horda primeva, como veremos em Lévi-Strauss. 
Se até aqui vimos como o empirismo escrupuloso crítico de Malinowski foi central para o esfriamento do diálogo entre sua antropologia e os postulados psicanalíticos da época, uma outra via de tensão dificulta ainda mais qualquer possibilidade de mútua contribuição. A vertente crítica do pensamento de Malinowski enfatiza essencialmente o papel da experiência concreta de campo para a construção de sua teoria. Entretanto, o movimento positivo de seu pensamento, aquele de construção e teorização sobre os fundamentos dos dados coletados, praticava, como aponta LéviStrauss, um simplismo redutor de tais fatos, uma "incursão desastrada no campo da sociologia comparada" (LÉVI-STRAUSS, 1949d, p.28). Em seu processo de indução generalizadora, Malinowski “constrói uma ponte entre o dado concreto (empiricamente observado) e o padrão universal na base de uma teoria instrumentalizante, utilitarista e semibiológica" (DA MATTA, 1983, p.13). Em outros termos, ao associar como fundamentos últimos das instituições seu valor utilitário, funcional, Malinowski recai em uma concepção de homem, na qual este se vê preso a suas necessidades básicas.

Portanto, Malinowski conjuga um projeto que a um só tempo busca estabelecer a multiplicidade critica de descrições dos fatos de campo e que a concebe, em seu potencial universalizante, a partir de noções extraídas de concepções carregadas de um veio biologicista. Entre os anos de 1927 e 1929, portanto, ainda no calor do debate com as teses psicanalíticas, o antropólogo publica duas importantes obras que expressam bem a posição de seu projeto. Em Sexo e Repressão na Sociedade Selvagem, de 1927, encontramos um extenso comentário sobre a relatividade do complexo edípico, onde busca demonstrar como os modelos funcionais agenciam os instintos naturais. Em suas palavras:

Nós tentamos a averiguar a modificação essencial no investimento inato para mostrar o que entendemos que seriam as consequências disso para a mentalidade humana. No curso disso, nós naturalmente tocamos aos mais importantes problemas psicanalíticos, e nos habilitamos para oferecer uma teoria da formação natural do complexo familiar. Encontramos que o complexo é uma produção inevitável da cultura, que surge enquanto a família se desenvolve a partir de um grupo ligado pelos instintos, em um grupo conectado pelos laços culturais. (MALINOWSKI, 1927, p.215) 
Por esta leitura, mesmo fazendo questão de enfatizar o papel do fator sexual sobre dispositivos sociais, em especial dos sistemas de parentesco - o que poderia aproximá-lo de algumas leituras psicanalíticas - Malinowski não deixa de considerar as instituições como biologicamente determinadas em essência. Dois anos depois em um livro sobre a vida sexual dos melanésios - A Vida Sexual dos Selvagens do Noroeste da Melanésia (1929) - observamos um papel ainda mais preponderante da natureza sobre as instituições culturais, em especial sobre a universalidade do casamento, posto que para ele, na Melanésia encontra-se "a inclinação natural de todo homem após a primeira juventude de ter uma casa e um lar só seu [...] e [...] um desejo natural de ter filhos" (MALINOWSKI, 1929, p.81 - grifo meu). Por tais exemplo, temos um perfil de como o pensamento funcionalista de Malinowski concebe o lugar da cultura e do símbolo em suas análises.

Toda dimensão simbólica que se possa extrair das instituições observadas e da experiência de campo, em especial a mitologia, quando no momento de se reconstruir sua inteligibilidade, de se articular sua efetividade simbólica, ficam relegados a fenômenos de segundo plano, ou melhor, protofenômenos que não alçariam a dignidade de serem objetos privilegiados de análise de uma antropologia. Elas ficariam submetidas à análise de primeira ordem dos arranjos funcionais, como podemos notar no comentário a seguir sobre a instituição matrimonial:

Para falar francamente, eu diria que os conteúdos simbólico, representativo ou cerimonial do casamento têm, para o etnólogo, uma importância secundária [...] A verdadeira essência do ato do casamento é que, graças a uma cerimônia muito simples ou muito complicada, ele dá uma expressão pública, reconhecida coletivamente, ao fato de dois indivíduos ingressarem no estado de casamento (MALINOWSKI, 1934 apud LÉVI-STRAUSS, 1949d, p.27).

A vertente funcionalista de Malinowski, portanto, não desqualifica em suas análises o valor eficaz do símbolo, justamente por compreender que esta esfera, antes de se constituir como um meio para acesso ao que responde pelo universal do homem, trata de uma particularidade cuja significação está sempre remetida às relações funcionais. Em outros termos, o símbolo não estabeleceria um princípio autônomo de regulação e 
determinação da vida social. Veremos como a assunção de tal dimensão é essencial para um verdadeiro diálogo entre antropologia e psicanálise na obra de Lévi-Strauss.

Da querela aqui tratada, podemos dizer que um retumbante silêncio se abateu na interlocução, posto que "a partir desse contexto confuso e sem diálogo explícito e direto que se elaborou um ranço negativo e dificultoso no diálogo entre as disciplinas." (BARROS; BAIRRÃO, 2010, p.47). Nas palavras de Pulman:

Por um lado, os cientistas sociais e, mais especificamente os antropólogos, continuam a criticar o veio "universalizante" da psicanálise e os psicanalistas parecem se resguardar dos seus limites nas análises da cultura e se restringem progressivamente à clínica individual (PULMAN, 2002 apud BARROS; BAIRRÃO, 2010, p.49).

\subsection{Boas e a introdução da dimensão inconsciente dos fenômenos sociais}

No plano geral da crítica de Malinowski à psicanálise, encontramos de fundo uma crítica maior ao que esta supostamente se assemelhava metodologicamente à concepção evolucionista presente quando do surgimento da antropologia como uma disciplina sui generis, na metade do século XIX (LAPLANTINE, 1987, p.65). No entanto, se o posicionamento de Malinowski recai em um funcionalismo achatador da efetividade da dimensão simbólica dos dados coletados em campo, outra foi a solução encontrada por seu antecessor e pioneiro na crítica ao método evolucionista, a saber, o antropólogo alemão Franz Boas.

Considerado por Lévi-Strauss (1952, p.303) um dos precursores do pensamento estruturalista, Boas foi o principal responsável por remodelar e definir as principais linhas de desenvolvimento da antropologia americana até metade do século XX (STOCKING, 1999, p.9). Nesta via, encontramos em sua obra desde o empirismo crítico de Lowie, até as configurações culturais de Benedict e a atenção à psicologia individual em sua relação com a cultura de Mead (LÉVI-STRAUSS, 1988, p.62), referências que em maior ou menor grau estabeleceram uma interlocução com a psicanálise (MICELA, 1982, p.100). Entretanto, como veremos a seguir, a relevância de sua obra ressoa o domínio de Boas da totalidade do campo etnológico, posto que sua 
formação cobria o extenso espectro de áreas como a antropologia física, linguística, etnografia, mitologia, arqueologia, folclore (LÉVI-STRAUSS, 1988, p.59).

Se a antropologia de Boas foi uma peça central na apropriação lévi-straussiana da psicanálise, não podemos dizer que o diálogo entre o próprio Boas e Freud tenha sido dos mais fecundos. Contemporâneos, e talvez com correlações em suas produções maiores que as percebidas até hoje, são poucos os momentos em que vemos um se referir ao outro. De um lado, encontramos em toda a obra Freud, apenas uma referência a Boas: em Totem e Tabu (p.145), por conta da uma teoria formulada pelo etnólogo sobre o totemismo, derivado de suas etnografias realizadas entre os índios da Colúmbia Britânica. De outro lado, vemos Boas fazer uma menção especial à psicanálise quando da necessidade de diferenciar a noção de inconsciente na sua antropologia da versão apresentada - e então extensamente reconhecida no mundo acadêmico - pela psicanálise, como veremos à frente. Talvez o mais incisivo contato entre ambos os pensadores seja de valor histórico e tenha se dado na Clark University, quando da visita de Freud aos EUA, em 1909. Além de terem recebido honrarias por seus trabalhos enquanto "psicólogos", Boas generosamente cedeu a Freud o horário de sua fala para que este pudesse fazer uma palestra a mais. Ou seja, não fosse por Boas, um dos livros mais difundidos de Freud seria intitulado "Quatro Lições de Psicanálise", ao invés do título que hoje conhecemos (EVANS; KOELSCH, 1985, p.944). Para melhor apresentar o que entendemos como o diálogo entre a antropologia boasiana e a psicanálise, tomemos inicialmente sua crítica ao pensamento evolucionista.

Em 1887, Boas inaugura uma série de críticas aos pressupostos do modelo hegemônico do fazer antropológico de então e que será desenvolvido especialmente na última década do século XIX, quando da publicação de The limitations of the comparative method (Cf. STOCKING, 1999, p.161). Neste ano, Boas travou um embate com Otis Mason sobre sua metodologia de pesquisa, particularmente em relação a dois conceitos, o de causalidade e de classificação. No que diz respeito à causalidade, ela sempre foi posta em questão quando antropólogos se depararam com a "ocorrência de criações similares em áreas muito distanciadas" (BOAS, 1887, p.89). Mason, como representante da vertente evolucionista, explicava facilmente tal recorrência de criações como "invenções independentes", ou a partir do seguinte princípio: "Na cultura humana, como na natureza em toda parte, causas semelhantes produzem efeitos semelhantes. Sob o efeito da mesma pressão e dos mesmos recursos, surgirão as 
mesmas invenções" (BOAS, 1887, p.86). Contra esse tipo de argumentação, Boas defendia que há um tipo de causalidade que derruba essa lógica, justamente a que pressupõe que efeitos semelhantes podem ser produzidos por causas díspares. Portanto, não haveria reciprocidade entre a causas e efeitos: causas semelhantes podem produzir efeitos semelhantes, no entanto o inverso não é necessário - ponto no qual Boas seguia o filósofo John Stuart Mill (STOCKING, 1999, p.16).

Como sabemos, Stuart Mill fora uma referência fundamental à formação inicial de Freud, a ponto deste ter passado grande parte do período em que esteve de licença obrigatória para o cumprimento do serviço militar, entre 1879-1880, traduzindo quatro ensaios de $A$ System of Logic (1843) para o alemão (Cf. GAY, 1988, p.50). A teoria da "pluralidade de causas" de Mill, aparece ainda em seu estudo sobre as afasias, quando Freud postula que a representação de objeto (complexo associativo formado por representações táteis, acústicas, sinestésicas), em relação à representação de palavra, é dotada da possibilidade de uma grande sequência de novas impressões na mesma cadeia associativa. (FREUD, 1891, p.103). Ao que nos toca, a teoria de Mill permitia pensar em um modelo lógico de causalidade múltipla, com consequências sobre a teoria da associação, sobre a caracterização da etiologia no campo psicopatológico, assim como sobre a possibilidade se conceber um modelo de história destituído da tendência uniforme e teleológica pretendida pelo ideário evolucionista. Nos termos de LéviStrauss, "Boas reconhecia a infinita diversidade dos processos históricos pelos quais ele se constitui em cada caso" (LÉVI-STRAUSS, 1949d, p.21 - grifo meu). Veremos como esse último passo foi essencial à antropologia boasiana.

No que concerne à temática da classificação, a lógica comparativa a que recorria Mason e seus colegas era a da sobreposição de categorias comuns às coleções de museus sobre os artefatos e dados coletados em campo. Ao considerar a unidade básica da análise antropológica análoga ao "espécimen biológico, ele introduz as abstrações rígidas de espécie, gênero e família na etnologia” (BOAS, 1887, p.86). A crítica destrutiva de Boas à tipologia especulativa do fazer antropológico do fim do século XIX (VIVEIROS DE CASTRO, 1996, p.299), já mostrava em Boas um apreço pelo relativismo cultural, uma vez que considerava que, em suas palavras, "construções apressadas só conseguem fazer das populações estudadas reflexos de nossa própria sociedade.” (BOAS, 1936 apud LÉVI-STRAUSS, 1949d, p.30). Podemos resumir sua crítica da seguinte forma: 
Temos que estudar cada espécimen etnológico individualmente na sua história e no seu meio [...]. Não podemos compreender o significado de um artefacto singular se o considerarmos fora do seu ambiente, fora do contexto das Outras invenções do povo a que pertence e fora do contexto dos outros fenômenos que afetam esse povo e suas produções. Uma coleção de instrumentos usados para o mesmo fim ou feitos do mesmo material ensina apenas que o homem em diferentes regiões da Terra tem feito invenções semelhantes. Por outro lado, uma coleção que representa a vida de uma tribo permite compreender muito melhor o espécimen singular. Nossa objeção à ideia de Mason é que classificar não é explicar. (BOAS, 1887, p.87).

A crítica Boas, portanto, ia de encontro com a ideologia difundida desde Tylor de que seria possível abstrair e isolar elementos do mesmo tipo em culturas diferentes, em outros termos, de que se poderiam estudar, por exemplo, um arco e flecha produzidos por inúmeras sociedades como se eles por si constituíssem uma espécie.

Em resposta, a isso, Boas buscou uma dupla chave de análise dos dados: sua proposta foi a de empreender uma análise ao mesmo tempo sincrônica, ou seja, um estudo detalhado dos costumes e de seu lugar na cultura global da tribo, posto que cada elemento está inserido em um sistema de representação, assim instrumentos próximos na forma, não constituem a priori uma espécie (BOAS, 1896, p.276); e diacrônica, onde a reconstrução histórica - herdado do idealismo alemão, em especial da filosofia de Hegel (VIVEIROS DE CASTRO, 1996; STOCKING, 1999, p.27) - permitiria tratar o modo como as fatos chegaram a se constituir como tais. A história de um elemento, assim como as espécies classificatórias, seriam, em seu método, apreendidas por indução, cuja configuração na ciência antropológica dava a base necessária para derivar "as leis e a história do desenvolvimento da especificidade fisiológica e psicológica da humanidade" (BOAS, 1887, p.95), ou melhor, uma comparação das histórias do desenvolvimento poderia levar à descoberta de Leis gerais do desenvolvimento humano (BOAS, 1896, p.907).

Estes aspectos da crítica boasiana à ideia de causalidade e classificação, assim como os encaminhamentos em seu método derivados desta problemática, estão no 
centro de sua consideração pela psicanálise. Em The methods of ethnology, de 1920, Boas encerra seu artigo posicionando-se diante dos postulados de Totem e Tabu. Para ele, o empreendimento freudiano na interlocução com os dados antropológicos promovem uma interpretação da mitologia análoga à tradição simbolista de Stucken (BOAS, 1920, p.288). Este tipo de atitude, aceita por Rivers, como faz questão de enfatizar, daria forma a uma desconectada aplicação de atitudes psicologizantes com teorias de transmissão do passado. A principal crítica aqui de Boas é que Freud teria extrapolado seu escopo analítico ao transpor para o campo etnográfico os conceitos e dados formulados primeiramente em contato com seus pacientes pertencentes a culturas extremamente diversas das primeiras. A posição do antropólogo, a exemplo de seus pares, demonstra sua desconsideração pelos fatos sociais e etnográficos analisados por Freud. No entanto, esta crítica à unilateralidade da análise psicanalítica não vem acompanhada de um fechamento das vias de comunicação, muito pelo contrário, Boas reconhece na psicanálise uma disciplina frutífera para certos problemas etnológicos, como a da constância de comportamentos em determinadas condições sociais. Em suas palavras:

É certamente verdade que a influência de impressões recebidas durante os primeiros anos de vida tem sido subestimadas e que o comportamento social do homem depende em larga medida dos primeiros hábitos que são estabelecidos antes do período em que as memória conectada começa, e que muitos traços ditos raciais ou hereditários seriam melhor considerados se tratados como um resultado os exposição precoce a certas formas de condição social. (BOAS, 1920, p.289)

A psicanálise, por esta via, auxiliaria a realização do duplo projeto boasiano de “determinar, de um lado, as causas históricas da formação dos fatos etnográficos, e de outro, os processos psíquicos que os tornaram possíveis (LÉVI-STRAUSS, 1949d, p.19). Mais especificamente, a psicanálise, segundo Boas, poderia servir à crítica às teorias racialistas ao propor um modelo de histórico da origem dos comportamentos que assimilasse a incorporação individual da cultura fora dos limites da consciência, ou seja, de uma historicização dos dados que respondesse a um termo central na antropologia de Boas, a saber, o conceito de inconsciente. Entretanto, sob a pena do antropólogo, a 
noção de inconsciente antes de ter sua investigação centrada na observação da relação entre a psicologia individual do neurótico e do pretensamente são, deveria se centrar em um fato de maior relevância: o fenômeno da linguagem (BOAS, 1920, p.289).

Como salienta Lévi-Strauss, Boas não foi apenas um antropólogo, ele também foi um grande linguista. No entanto, isso não se refere apenas à impressionante produção de 12 gramáticas indígenas, cujas bases se encontram no Handbook of American Indian Languages, mas ao fato de ter sido, nas palavras de Lévi-Strauss:

Um dos primeiros - e antes de Saussure - a insistir sobre um fato essencial para as ciências humanas: as leis da linguagem funcionam ao nível do inconsciente, fora do controle dos sujeitos que falam, podendo-se então estudá-las como fenômenos objetivos, representativos, como tal, de outros fatos sociais (LÉVI-STRAUSS, 1988, p. 63) ${ }^{4}$.

Ora, como já se presencia no canônico prefácio do Handbook de 1911, Boas defendia a linguística como uma disciplina produtora de um modelo analógico para a interpretação de fenômenos socioculturais (VIVEIROS DE CASTRO, 1996, p.305). Uma das principais características do fato linguístico seria justamente a de que "seus conceitos gerais são inteiramente desconhecidos para a maioria das pessoas. Eles nunca emergem à consciência até que se introduza o estudo de uma gramática científica" (BOAS, 1911, p.67). Tais “conceitos gerais", ainda segundo Boas, são determinantes na produção de pensamentos e categorias que tem um estatuto eficaz na vivência dos homens. Como uma atividade inconsciente do espírito (Geist), eles seriam os responsáveis pela elaboração e inteligibilidade dos fenômenos sociais de todas as espécies (linguagem, crenças, técnicas e costumes) (Cf. LÉVI-STRAUSS, 1949a, p.147). O valor metodológico da linguística, nos termos de Boas:

Para desenhar um paralelo entre o fenômeno etnológico e o fenômeno linguístico, nos parece que a característica comum de ambas é o agrupamento de um número considerável de

\footnotetext{
${ }^{4}$ De forma sintética, Dosse expressa da seguinte forma o legado de Boas para pensamento de Lévi-Strauss: "A mais importante contribuição de Boas e sua influencia sobre Lévi-Strauss terão sido a ênfase que deu à natureza inconsciente dos fenômenos culturais e a colocação das leis da linguagem no centro da inteligibilidade dessa estrutura inconsciente. O impulso linguístico estava dado, oriundo do campo da antropologia, a partir de 1911, e iria favorecer a fecundidade do encontro de Lévi-Strauss e Jakobson" (DOSSE, 1992, p.37).
} 
atividades sob a forma de uma simples ideia, sem a necessidade desta ideia entrar ela mesma na consciência. [...] Acredito que a formação inconsciente dessas categorias é um dos traços fundamentais da vida étnica. (BOAS, 1911, p.70)

A pesquisa etnológica, a partir do modelo linguístico, poderia então operar uma análise de seus dados que abstraísse das racionalizações secundárias de suas categorias, sua infraestrutura inconsciente (ROSSI, 1973, p.27). Devemos, no entanto, nos acercar do fato de que não há ainda em Boas uma consideração pela linguagem como um modelo lógico em essência. Se ela aqui tem um papel central, seu valor operativo deve ser o de uma forma de expressão na qual as categorias etnológicas seriam realizadas e acessíveis de modo menos distorcido que pelos relatos coletados em campo. Nas palavras de Boas:

Então isso nos parece que de um ponto de vista prático e teórico, o estudo da linguagem deve ser considerado como um dos ramos mais importantes do estudo etnológico, porque, de um lado, uma compreensão global na etnologia não pode ser obtida sem um conhecimento prático da linguagem, e, de outro lado, os conceitos fundamentais ilustrados pelas linguagens humanas não são distintos em essencial do fenômeno etnológico; e porque, além do mais, as características peculiares das linguagens são claramente refletidas nas visões e costumes dos povos no mundo. (BOAS, 1911, p.73).

De maneira sintética, como Viveiros de Castro aponta, Lévi-Strauss herdou da antropologia boasiana desde a questão da relação entre universais psicológicos e os determinismos culturais, até o modelo analógico da linguagem, a oposição entre natureza e cultura, e a dimensão inconsciente dos fenômenos sociais. Mas poderíamos aqui acrescentar a valorização da mitologia para a pesquisa antropológica. Na obra de Boas, o acúmulo de uma extensa massa de mitos, motivo de zombaria por seus pares (LÉVI-STRAUSS, 1988, p.63), não responde apenas por uma relativização do valor de cada fato etnológico - derivada tanto da crítica ao método de classificação a priori, quanto da noção de atividade inconsciente do espírito - ou por uma consequência lógica da própria atividade etnográfica, ela responde primeiramente pela posição estratégica que o mito ocupa na economia de seu pensamento. 
Como se sabe, a antropologia cultural da qual Boas é o precursor, tem como programa principal retraçar o desenvolvimento e a transmissão da cultura (LÉVISTRAUSS, 1954, p.380) entre as gerações ou entre povos de áreas distintas. A difusão do elemento cultural seguia uma lógica que, para Boas, não era de simples assimilação unilateral. Ao formular a existência de uma atividade inconsciente que enformaria tais trocas, Boas reconhecia no "processo de construção do mito a constituição de um modelo de desenvolvimento da cultura em geral" (STOCKING, 1999, p.162). A bela citação pela qual Lévi-Strauss prefacia seu artigo $A$ estrutura dos mitos ${ }^{5}$, extraída de Boas, já demonstra o viés dinâmico pelo qual este se apropria da produção mítica.

Viveiros de Castro ressalta que para a antropologia boasiana, o indivíduo opera como um lócus real da integração cultural, ou seja, a cultura opera na mente dos indivíduos como uma realidade extra-somática de tipo ideacional que conforma cada um aos seus padrões (VIVEIROS DE CASTRO, 1996, p.303). Como Stocking indica, a partir do início do século XX, Boas foi cada vez mais centrando suas pesquisas no que chamou de o "gênio de um povo" (STOCKING, 1999, p.23), ou seja, os condicionantes psicológicos que, mesmo pretensamente universais, configuram a maneira como cada grupo individualmente assimilam a cultura, especialmente na troca com populações vizinhas. Os mitos serviriam como um fenômeno privilegiado de observação dessas transformações culturais na assimilação. Como Stocking nos diz:

O ponto principal era que a cultura humana se desenvolvia sempre em um contexto histórico específico, dado pelo modo como os homens numa situação cultural particular remodelavam e rearranjavam os materiais que recebiam por tradição ou de outros homens com quem tinha entrado em contato. (STOCKING, 1999, p.162).

A antropologia de Boas, portanto, concebia o fenômeno mítico como uma via de acesso à atividade inconsciente do espírito, principalmente pelo fato de aí se articular conceitos que poderiam servir de base para a análise de outros fatos etnológicos, como os modos à mesa ou receitas culinárias (Cf. BOAS, 1911). O mito por tal visão - como veremos à frente, largamente empreendida por Lévi-Strauss e próxima do que Mauss

\footnotetext{
5 "Dir-se-ia que os universos mitológicos estão fadados a serem pulverizados assim que se formam, para que novos universos nasçam de seus destroços.” (Boas, 1898 apud LÉVI-STRAUSS, 1955, p.221)
} 
(1924) conceberá como "fato social total” - e, em especial, seu processo de construção, constitui um operador central para chegar à reconstrução histórica dos fatos etnológicos almejada por Boas.

Entretanto, o rigor do antropólogo para tal reconstrução impunha tantas condições que tornará praticamente estéril sua execução, lição apreendida por Malinowski e seu método de análise essencialmente sincrônico. Por outro lado, se tal busca o fez referir-se à psicanálise como uma ciência auxiliar, não o fez levar tal diálogo adiante, como o fará futuramente Rivers em seu apreço pela historicidade inerente à psicanálise, e, como veremos no próximo capítulo, Lévi-Strauss em sua articulação com a temática do mito e da linguagem, agora vistos em seu valor lógico, a partir do desenvolvimento da linguística estrutural.

\subsection{Rivers e o valor da diagnóstica psicanalítica para a etnologia}

Ao lado de Boas, Mauss e Malinowski, William H. R. Rivers é considerado atualmente um dos pais da etnografia moderna, responsável por formular uma prática de campo e um método de pesquisa. Seu nome, entretanto, esteve à parte da história da disciplina antropológica por muitos anos, pois, como defende Pulman (1986, p.120), seu reconhecimento frente aos seus pares esteve indissociado do destino dado à psicanálise, tamanha a identificação de sua imagem com os postulados psicanalíticos. Com uma formação distribuída entre os campos da psiquiatria, psicologia e etnologia, Rivers foi um dos primeiros etnólogos a tomar posição frente aos postulados freudianos - decerto o primeiro na antropologia britânica - posto que já em 1916 os trabalhava para extrair o justo valor para sua prática clínica e etnográfica. Marcado por uma múltipla inserção institucional, Rivers foi concomitantemente presidente da seção de psicologia da British Association for the Advancement of Science e da Royal Anthropological Institute, além de ter sido membro da recém-criada British Psychoanalitical Society, fundada em 1919 por Ernst Jones. A esta multiplicidade responde um método de análise que parte por uma dupla via: de um lado, encontramos um viés histórico-geográfico, e de outro, um viés psicológico e lógico assimilado posteriormente por Mauss, Radcliffe-Brown e Malinowski, papel que lhe rendeu, na pena de Lévi-Strauss, o reconhecimento póstumo de ter sido o "Galileu da etnologia” (LÉVI-STRAUSS, 1952, p. 180). 
Rivers, para além de todas essas convergências, tem ainda um duplo papel na economia das trocas com a psicanálise: o primeiro é o fato de ter sido um dos precursores de um ramo da antropologia denominado antropologia da doença, ou antropologia dos sistemas de saúde. (LANGDON, 1994). O segundo está na forma como Rivers se apropriou da obra freudiana posto que, à revelia de seus contemporâneos, aproximou-se da psicanálise não com a leitura de Totem e Tabu e da tese freudiana da origem da cultura, mas através de $A$ Interpretação dos Sonhos e do seu valor metodológico para a investigação de campo (PULMAN, 2002, p. 130). Como veremos, este segundo fator teve como condição sine qua non a exigência de formalização da relação diferencial entre sistemas de saúde.

As quatro conferências realizadas diante Royal College of Physicians of London, entre 1915 e 1916, postumamente publicadas sob o título de Medicine, Magic and Religion (RIVERS, 1924), marcaram o início de uma abordagem sistemática das teorias da doença e da cura das sociedades nativas. Nas palavras de J. Langdon:

Com formação em medicina, ele se preocupava com a caracterização ou a classificação da medicina primitiva segundo categorias de pensamento, identificado na época como pensamento mágico, religioso, ou naturalista. Estabelecidas por Frazer, Tylor, e outros, estas categorias foram comuns em vários debates sobre o pensamento primitivo. Rivers (1979) empregouas para classificar as crenças sobre etiologia das outras culturas, afirmando que 'Partindo da etiologia, encontramos naturalmente uma via para o diagnóstico e tratamento, como é o caso em nosso próprio sistema de medicina' (LANGDON, 1994, p.4).

A antropologia que até então tratara nos escritos de Frazer, Mauss e Malinowski sobre a magia, Tylor sobre a religião, Mauss sobre o corpo, EvansPritchard sobre a etiologia, e vários outros que exploraram aspectos do mundo "primitivo" (Ibidem), defrontava-se pela primeira vez com uma remodulação de tais temas para se adequar à apreensão das práticas médico-religiosas, xamânicas, como um sistema cultural similar aos demais sistemas culturais estudados pelos antropólogos, tais como a religião, a política, etc. (Cf. KLEIMAN, 1980). Como afirma Rivers: 
Devemos encontrar que, mesmo quando não há diferenciação entre o curandeiro e outros membros da sociedade, os homens têm teorias da causação da doença que carregam consigo procedimentos que correspondem com aqueles que chamamos de diagnose e prognose, e finalmente tem modos de tratamento que, mesmo se têm pouco em comum com nossos próprios remédios, ainda sim devem ser vistos como formando um sistema terapêutico definido. (RIVERS, 1924, p.6)

A abordagem sistêmica, a introdução da consideração pela medicina em sua integração num sistema cultural e a identificação da etiologia como uma importante porta de entrada para se entender os procedimentos diagnósticos e terapêuticos, podem ser vistos como três grandes desenvolvimentos de Rivers neste campo. Três diretrizes que, ao menos quanto ao método, persistiram nos desdobramentos desta disciplina nascente.

A temática da etiologia, na interface entre psicanálise e antropologia, como vimos desde Freud, traça, na determinação dos fatores configuradores de um fenômeno, as incidências entre o particular da história e universal da constituição. Se na obra freudiana encontramos uma teoria das causas que aposta na indissociabilidade entre estes dois campos - posto que há uma relação interna entre os fatores constitucionais e contingentes, somente separáveis num período pré-histórico, mítico, anterior à ordem humana (e decisivo para seu futuro desenvolvimento), como tratado em Totem e Tabupara os antropólogos que vimos até aqui a interação entre esses fatores recebem outra leitura. De um lado, encontramos em Malinowski uma perspectiva sincrônica de análise que submete as operações da história à lógica funcional, ou seja, vê a diferença entre sociedades pautada em distintos modos de lidar com o universal do instinto; de outro, encontramos Boas compreendendo o papel seminal da história na determinação do universal, entretanto, uma história marcada por uma pluralidade de possibilidades que lhe dificulta a construção de postulados sobre a constituição e sua universalidade. Entre estes dois pólos, encontramos Rivers em sua articulação entre uma história unificada pelas teses difusionistas, como veremos à frente, e uma concepção de constituição psicológica, à qual responde sua particular assimilação da teoria freudiana.

Em Sociology and psychology, de 1916, Rivers introduz a psicanálise na economia conceitual de seu pensamento. A metáfora que abre essa relação é a da 
cooperação entre as disciplinas para a edificação daquele ramo das ciências exatas que se aproximava da sociologia quanto ao método empregado, a saber, a geologia. A geologia, assim como a sociologia, teria por missão, para Rivers, estudar a relação entre a estrutura - social, de um lado, terrestre, de outro - com a história, ou melhor, com as transformações seja da civilização, seja dos usos do solo. Para tanto, elas podem se valer dos conhecimentos produzidos em outros ramos, adjacentes que teriam a contribuir para a construção de suas análises, eis onde a psicologia, em especial a forjada pela psicanálise, encontraria seu papel. Vale ressaltar que a geologia também esteve presente quando da aproximação entre a psicanálise e a antropologia social realizada por Claude Lévi-Strauss. No entanto, neste segundo caso, mais do que acentuar as estratégias de cooperação entre campos do saber científico, Lévi-Strauss assinala a homologia de método presente na psicanálise e na geologia, pois, para ambas, diante de fenômenos de aparência impenetráveis, o pesquisador deve lançar mão de qualidades delicadas e, desse modo, a ordem que se introduz num conjunto a primeira vista incoerente não é contingente, nem arbitrária (LÉVI-STRAUSS, 1955, p. 55).

Ora, mas o quê na especificidade do saber psicanalítico a habilitaria para ser uma disciplina auxiliar no projeto da sociologia histórica de Rivers? Antes de entrar em contato com os escritos de Freud, pelo menos de o relatar, Rivers já tinha o reconhecimento da comunidade científica como um dos principais críticos da antropologia evolucionista, aquela que, como já tratado, forneceu a maioria dos teóricos de base para a incursão freudiana sobre a etnologia. A exigência de um rigor metodológico na reconstrução histórica da estrutura social, rigor atrapalhado pelas premissas evolucionistas (Cf. ROUDINESCO, 1998, p.xv), levou Rivers a adotar não o funcionalismo de Malinowski ou o culturalismo de Boas, mas as teses hiperdifusionistas de George Elliot-Smith e de W. J. Perry. Para os hiperdifusionistas, não havia nenhum desenvolvimento independente de culturas: "a civilização teria aparecido no vale do Nilo, depois teria se difundido, por via da navegação, até terras tão distantes quanto as ilhas Salomão" (RIVERS, 1922 apud PULMAN, p.127). É a temática da universalidade, ou seja, dos determinantes da recorrência de costumes e fatos sociais que estava aqui em jogo. Enquanto a corrente de inspiração evolucionista aposta na onipresença de um padrão de desenvolvimento psíquico comum de Tylor e Bastian, Rivers aposta na troca e recíproca influência através de contatos diretos entre diferentes culturas passíveis de serem remontados historicamente (ELLIOT-SMITH, 1926, p.xv). 
Eis contexto teórico-metodológico do projeto de pesquisa etnológico de Rivers quando este se depara com a psicanálise, no entanto, o cenário deste primeiro encontro foi mais próximo do setting analítico que de seu fazer etnológico.

No verão de 1915, em pleno auge dos conflitos da I Grande Guerra, o já consagrado etnólogo e psiquiatra Dr. Rivers serviu como médico no Hospital Militar de Maghull. Nos três meses de serviço, teve como principal tarefa investigar e tratar os efeitos mentais do estresse e da pressão das trincheiras de guerra sobre os soldados enfermos. Neste meio, Rivers percebeu que o "processo de diagnosticar uma doença era similar ao processo que estava utilizando na Melanésia para revelar o sentido das práticas religiosas e sociais nos povos de culturas inferiores" (ELLIOT-SMITH, 1924, p. vi). O diagnóstico e o tratamento das neuroses traumáticas de guerra passavam pelos sonhos dos soldados, onde o trabalho de Freud acolheu Rivers em sua clínica. Ora, se o método psicanalítico permitia a leitura dos fatores mantenedores dos sintomas dos enfermos, ele poderia ser também de grande valor para a tarefa do diagnóstico social realizado pela etnologia. Vale a ressalva que a noção de diagnóstica remete-se aqui ao trabalho de reconstrução dos determinantes estruturais e contingentes para a formação de um dado fenômeno.

Pulman (2004) em um extenso trabalho sobre a assimilação de Rivers da psicanálise aponta três direcionamentos principais dos vieses e distorções de sua apropriação: o primeiro é a aceitação parcial da teoria dos sonhos, ele opera com a distinção conceitual de sonho latente e sonho manifesto e de que há uma transformação de um a outro (Ibidem, p.130), mas rechaça os fatores sexuais envolvidos em sua produção; o segundo, intimamente relacionado aos dois outros pontos, diria respeito aos objetivos e condução de sua prática terapêutica. A cura, em suas palavras, deve "permitir ao paciente viver em harmonia com a sociedade à qual ele pertence e que havia apartado [...] a lembrança da saúde e felicidade" (RIVERS, 1924, p. 133). A visão adaptacionista estava de acordo com os objetivos de seu meio belicoso. A conduta do terapeuta, por sua vez, seria a de dirigir uma série de "conversas onde o terapeuta encoraja o paciente a lhe contar suas experiências dolorosas, para então, lhe mostrar o lado bom da situação" (RIVERS, 1920, p.212) .

\footnotetext{
${ }^{6}$ No artigo de Pulman, encontramos o seguinte comentário: "Muito intervencionista, ele dava conselhos a seus pacientes, por exemplo, sobre suas escolhas profissionais; ele misturava suas relações de amizade e tratamento, e não compreendia visivelmente o que se dava na transferência (1923a: 35-36). A
} 
O último ponto diria respeito ao estatuto do inconsciente na teorização de Rivers. Enquanto "reservatório de fontes do passado", o inconsciente e suas formações tratam de eventos, fatos históricos ocorridos e não de representações, como postula Freud. Este mal-entendido é essencial para o valor da psicanálise para seu projeto de defender uma abordagem hiperdifusionista na antropologia, posto que será o ponto de partida para o estabelecimento de uma homologia entre os mecanismos do sonho e da vida social dos selvagens. A destituição da fantasia, e consequentemente, a emergência de um argumento próximo da noção de trauma inerente à teoria da sedução, pode ser vislumbrada na reconstituição de Pulman do raciocínio analógico de Rivers:

O sonho exprime de uma maneira 'condensada' o conjunto de experiências vividas pelo sonhador ao longo de sua existência. Ora, uma vez admitida essa definição eventual, a transposição do conceito de condensação ao estudo das sociedades primitivas torna-se, em sua ótica, evidente. Nestas sociedades, dizem, cada traço cultural 'possui seus próprios antecedentes históricos bem determinados e constitui simplesmente o produto final e altamente condensado de uma longa e complexa cadeia de eventos' (Rivers 1918a: 14). Cada elemento atual da vida social condensa, em suas características, a história de uma cultura e notadamente de seus contatos com outras culturas. (PULMAN, 2004, p.133)

Pode-se perceber por esses três pontos que é justa a colocação de Rohéim de que aquilo que Rivers aceita da teoria freudiana é pouco comparado com o que rejeita: justamente a essência da descoberta psicanalítica, da sexualidade e do fantasma (ROHÉIM, 1947, p.14). Sem aqui apelarmos para o argumento de que o acesso à obra de Freud naquele momento era substancialmente dificultoso, devemos ressaltar a importância de Rivers no diálogo com a psicanálise.

Como vimos na querela entre Jones e Malinowski, havia uma dupla hiância em seu diálogo, essencialmente, por conta de um lado lidar com a realidade do complexo edípico sob uma chave representacionista, ou seja, as imagens dos elementos dados na 
situação do conflito edipiano como precedendo as relações lógicas entre seus termos, e do outro, enfatizar a realidade do fenômeno como dado por sua imediaticidade. Com Rivers, encontramos o reconhecimento de que a leitura do dado etnográfico é homóloga ao exercício de leitura realizada no diagnóstico clínico, ou seja, que em ambas haveria a reconstrução histórica e estrutural dos determinantes que condicionam um dado fenômeno clínico ou social. A possibilidade de pensar um fenômeno como produzido por condições não imediatamente acessíveis, semelhante à posição de Boas, mas que aqui surge pressuposta na aceitação das facetas manifesta e latente do sonho, abre a possibilidade de se pensar a articulação entre o plano de expressão dos fenômenos e sua estruturalidade que, sob a pena de Rivers, redundam em uma abordagem histórica do que não se dá de imediato.

Ora, este historicismo de Rivers, influenciado por um espírito difusionista, marca um importante passo no diálogo entre as duas disciplinas, entre os quais podemos salientar três pontos: em primeiro lugar, ao distanciar-se das teses evolucionistas, Rivers deixa de enfatizar um caráter universal pressuposto no homem e, consequentemente, uma tese biologicista que solucionasse a recorrência de costumes e formas sociais em locais distantes pelo mundo. Tal recorrência passa, então, a ser descrita por contatos historicamente datados, postulado dificilmente defensável e que teve um curto legado na antropologia. No entanto, ela conduz a uma interessante consequência: ao se desvencilhar de um universal no desenvolvimento humano, Rivers acede a uma concepção de homem que não traria consigo uma hierarquia no seu grau de racionalidade. Ou seja, a partir de tal ponto de vista ele pode descrever sistemas de produção do fenômeno patológico - sistemas mágicos, religiosos e naturalistas (RIVERS, 1924, p.7) - como racionais na mesma medida, e assim fundar uma disciplina que permitirá à antropologia dialogar com a psicanálise no campo dos princípios que regem a experiência clínica (Cf. RIVERS, 1924, p.48). O abismo entre as categorias falaciosas de homem "evoluído" e homem "primitivo", por tal operação pode ser superada na antropologia de Rivers.

Em segundo lugar, mesmo que em sua prática clínica não tenha assimilado grande parte do que seria considerado próprio do fazer psicanalítico enquanto prática de cura, Rivers abriu a possibilidade de que as relações entre psicanálise e outros métodos de tratamento, fossem tratadas em um duplo nível histórico e estrutural, de vez que os sistemas de doença descritos por Rivers se valem de termos relacionais. Em suas 
palavras: "Medicina, magia e religião são termos abstratos, cada qual denota um grande grupo de processos sociais, processos pelos quais a humanidade tomou para regular seu comportamento sobre o mundo em volta" (RIVERS, 1924, p.1). Enquanto processos sociais servem a uma tipologia que não se adéqua a uma única região e, via de regra, encontra expressão das três facetas nas mais diversas culturas, incluindo a nossa própria.

Por último, podemos dizer que a adesão à teoria difusionista impediu Rivers de lidar com um possibilidade de universal articulada à dinâmica temporal pressuposta pelo símbolo, em especial articulado na categoria de mito, tal como já tratado pela psicanálise e futuramente pela antropologia. Assim como a verdadeira determinação dos fenômenos, sociais ou individuais, residia em uma cadeia de eventos passados vividos, a realidade mítica, na concepção de Rivers, apresentavam pouco peso na construção de sua teoria se comparado ao lastro de um dado histórico, posto que os mitos são, em geral, desconexos e abundantes em roteiros imaginários e contraditórios.

Se até aqui observamos as diversas posições do fenômeno mítico nas antropologias de Malinowski, Rivers e Boas, não deixa de ser patente a importância que a mitologia toma na obra deste último em comparação com os demais. Veremos como a emergência da obra de Mauss, em sua rearticulação entre história e estrutura, pendendo para o último termo, além de recolocar o mito como um fenômeno central para suas análises, abre espaço para a introdução do método estrutural nas ciências sociais realizada por Lévi-Strauss

\subsection{Mauss e a eficácia do símbolo: o fato social total}

Para situarmos a posição do projeto teórico-metodológico de Lévi-Strauss, assim como o papel aí desempenhado pelo diálogo com a psicanálise, passamos até o momento por três dos maiores representantes do fazer antropológico no início do século $\mathrm{XX}$. A unidade destas obras, que justificariam a leitura didática deste momento como o da emergência do período moderno da disciplina, não se encontra, como vimos, na formulação de axiomas e paradigmas comuns que permitissem a unificação do campo, haja vista que cada obra inaugurou uma escola em particular: a antropologia funcionalista, com Malinowski; culturalista, com Boas; e, com Rivers, a corrente hiperdifusionista na correlação com a psicanálise. A unidade, portanto, deveria ser caracterizada antes a partir de um estatuto negativo: todas elas buscam responder aos 
abusos da ideologia evolucionista na prática e teoria antropológica, não apenas com uma crítica ferrenha aos seus pressupostos, como pela postulação de um método que legitime uma forma diferente de olhar, pensar o outro, o estrangeiro.

Neste ínterim, o papel do mito, como dispositivo simbólico central para atingir o que seria estrutural do homem, vai ganhando mais ou menos força a depender das modulações próprias de cada teórico. Aqui a obra do antropólogo francês Marcel Mauss aparece como marcando um ponto de virada tanto no fazer metodológico, quanto no próprio entendimento da efetividade simbólica para a determinação dos diversos aspectos da vida social, portanto, como um meio no interior do qual a antropologia deveria se debruçar cada vez mais. Vejamos como sua obra contribui para o posicionamento do pensamento lévi-straussiano no diálogo com a psicanálise e principalmente, na revaloração da categoria mítica como objeto de análise.

Marcel Mauss não só reconhecido e celebrado como o grande nome da antropologia francesa no início do século XX, como é visto, em verdade, no lugar de fundador de tal disciplina em solo francês. Certamente ele não alcançou no interior da história do pensamento ocidental um papel tão eminente como o de seu tio e mentor da primeira parte de sua obra, Émile Durkheim, pai do método sociológico e responsável pela constituição da sociologia como uma disciplina sui generis. Alguns fatores concorrem para tal, como a difícil sistematização de sua obra, haja vista que não produziu livros e grandes textos metodológicos, nem teve uma produção centrada em temas que nem sempre dialogaram entre si (DUBAR, 1969, p.516), detendo-se sobre os mais diversos fenômenos.

Representante da cátedra de história da religião dos povos sem escrita da EPHE e posteriormente da cadeira de antropologia social do Collège de France, Mauss dedicou grande parte de seu ensino à transmissão oral, em seus cursos por onde passaram e foram treinados como etnógrafos grandes nomes como Claude Lévi-Strauss, Alfred Métraux, Maurice Leenhardt, Marcel Griaule, Georges Bataille e Louis Dumont (LEACOCK, 1954, p.71), para citar alguns. Para além de sua vida acadêmica, cujos feitos ainda remetem à introdução do vernáculo "antropologia social" em solo francês (LÉVI-STRAUSS, 1960, p.47), Mauss foi responsável pela inauguração de uma nova era das ciências sociais, em especial da teoria etnológica (LÉVI-STRAUSS, 1950, p.17). Em Ensaio sobre a dádiva, de 1924, o pensamento etnológico se vê pela primeira vez transcendendo à observação empírica a partir de um método em que o social sai do 
registro de análise qualitativa e passa a ser tomado a partir da noção de sistema (Ibidem, p.31). Tal metodologia de análise, pressuposta na noção de fato social total, como veremos à frente, justificaria a insígnia que Lévi-Strauss lhe rendera: se Rivers pode ser considerado como o Galileu da etnologia, Mauss, ao substituir o modelo de interpretação histórica por um referencial psicossociológico, fundado na noção de reciprocidade, pode ser considerado seu Newton (LÉVI-STRAUSS, 1952, p.178).

A especificidade da abordagem de Mauss, da análise em profundidade de um dado fenômeno, para restituir-lhe o valor concreto de experiência tal qual vivenciado por aquele que o apresenta, fez com que ele reestabelecesse um estreito laço com as ciências deixadas de lado pela sociologia durkheimeana, entre elas, a história, a biologia, direito e psicologia (LÉVI-STRAUSS, 1960, p.48). No que concerne a esta última e à então recém-formada psicanálise, podemos assinalar que Mauss manteve um estreito vínculo em sua obra. Além de publicar no Journal de Psychologie Normale e Pathologie, sua reputação como eminente sociólogo lhe rendeu a presidência da Société de Psychologie entre 1923 e 1926 (LEACOCK, 1954, p.68), quando publicou importantes artigos de mútua colaboração entre os campos da antropologia e da psicologia. Acerca do diálogo com a psicanálise, em particular, Mauss não foi o maior interlocutor da obra freudiana, seguindo seus pares na crítica à Totem e Tabu, por ele denominado "o último dos livros de sistema, cifrado, não havendo razão para que se multipliquem" (MAUSS, 1924, p.327). No entanto, sua posição não era de rechaço às pesquisas psicanalíticas, muito pelo contrário. Se repelia os "excessos da psicanálise" sobre o campo social, enaltecia a possibilidade de contribuir sob dois vieses principais, o primeiro centrado na possibilidade de extração dos resultados psicanalíticos sobre os fenômenos individuais, como ele notamos a seguir:

A hipótese de um estado de consciência inteira, de um estado que por si mesmo tem uma força de desenvolvimento, de proliferação, de desvio [...] que se apossa do ser psicológico inteiro, essa hipótese deve tornar-se comum a nós. [...] acreditamos que tais ideias têm uma imensa capacidade de desenvolvimento e de persistência, e, pela maneira como elas frequentam a consciência individual, compreendemos melhor a maneira como são acreditadas quando, praticadas pelo grupo em 
conjunto, são verificadas pela obsessão comum do grupo. (MAUSS, 1924, p.328-9)

As observações psicanalíticas, portanto, esclareceriam uma série de fatos sociais, "como a mitomania, loucura judiciária, fanatismo, alucinações do culto funerário, alucinações e sonhos coletivos". Assim, à semelhança de Rivers, conclui Mauss: "nada das novas teorias do sonho deveria nos ser alheio" (Ibidem), inclusive sendo um terreno decisivo para a possibilidade de análise da "questão mais difícil da etnologia, a mitologia" (MAUSS, 1925, p.240). Mauss aposta que a interpretação de um dado conjunto de sonhos pode dar "a chave de numerosos mitos presentes em todas as mitologias" (MAUSS, 1924, p.329).

Outra chave de aproximação com a psicanálise se dá no âmbito da pesquisa sobre as técnicas do corpo. Mauss reconhecia a importância seminal desse gênero de estudos para as investigações sobre a integração cultural, ou seja, sobre as relações de mútua influência entre grupo e indivíduo. Tal via estava em íntimo contato com as pesquisas de Benedict e Mead nos anos seguintes. Nas palavras de Lévi-Strauss:

Ao afirmar o valor crucial, para as ciências do homem, de um estudo da maneira pela qual cada sociedade impõe ao indivíduo um uso rigorosamente determinado de seu corpo, Mauss anuncia as mais atuais preocupações da escola antropologia americana [...] É por intermédio da educação das necessidades e das atividades corporais que a estrutura social imprime sua marca nos indivíduos. (LÉVI-STRAUSS, 1950, p.12)

O estudo da educação da criança, portanto, é necessário ser realizado "até mesmo em seus detalhes" (MAUSS, 1935, p.411), eis onde a psicanálise contribuiria como um modo de acessar os "estados psíquicos desaparecidos de nossas infâncias, produzidos por contatos de sexos e de peles" (Ibidem, p.413). Neste âmbito, próximo da posição vista em Boas, Mauss se reconhece "em plena psicanálise, provavelmente bastante fundamentada aqui” (Ibidem, p.417). Lévi-Strauss aponta ainda a importância percebida por Mauss do "momento e das modalidades do desmame e das maneiras pelas quais o bebe é manuseado. Mauss entrevê inclusive uma classificação dos grupos humanos em 'povos com berços e povos sem berços"” (LÉVI-STRAUSS, 1950, p.7). 
Deste contato de Mauss com a psicanálise, portanto, podemos considerar que se algum tipo de cooperação é possível, é não somente pelo fato de que a psicanálise opera a investigação dos fenômenos individuais cujos correlatos sociológicos são realizados pela etnologia, como também pelo fato último de que a prevalência do valor simbólico dessas manifestações extrapola a particularidade da experiência de seus agentes (DESCOMBES, 1979, p.659). Vejamos como Mauss articula tal noção de determinação simbólica e quais suas consequências metodológicas para o fazer antropológico derivado daí.

Em La méthode de Marcel Mauss (1969), Claude Dubar propõe dividir a obra de Mauss em dois períodos: o primeiro momento, correspondente à série inicial da revista Anné Sociologique (1898-1912), fundada e dirigida por Durkheim, cuja seção "sociologia religiosa" ficou a cargo de Mauss. Aqui, ainda encontramos um Mauss essencialmente influenciado pelo método de análise proposto pelo tio. Em uma segunda fase, cuja publicação de Ensaio sobre a dádiva marca a inauguração, Mauss promove a ruptura epistemológica com a sociologia francesa necessária para a reformulação do campo próprio de análise antropológica. Tomemos o ponto de partida da obra maussiana.

A metodologia impressa em As Regras do Método Sociológico, de Durkheim, marca o primeiro referencial de análise assumido por Mauss, principalmente nos escritos sobre magia, sacrifício e totemismo. Temos aí uma receita de tratamento dos dados próprios à edificação de uma disciplina que se quer independente de outros campos do saber. De maneira resumida, seu procedimento estava embasado em quatro passos fundamentais: necessidade de ruptura epistemológica com a língua corrente como meio de uma definição provisória precisa para o contorno do objeto de análise (como as definições de sacrifício, magia ou medo); primado da observação sistemática sobre a elaboração ideológica; crítica científica das fontes utilizadas; pesquisa de leis gerais em meio ao estudo comparativo de fenômenos particulares (DUBAR, 1969, p.516) O objetivo do procedimento geral era realizar uma análise que partisse da experiência concreta imediata até chegar à dimensão abstrata inteligível e responsável por tais configurações de fatos. Respondendo ao projeto durkheimeano, Mauss imprimia às análises uma explicação do social pelo social, cujo valor se encontrava tanto na crítica aos antropólogos evolucionistas e suas projeções sobre o funcionamento mental de fenômenos sociais, em especial Marillier com quem estudara (LEACOCK, 
1954, p.61), quanto na possibilidade de ir além do plano descritivo e alçar generalizações explicativas dos fenômenos (DUBAR, 1969, p.517). Os perigos da metodologia durkheimeana, como a desencarnação do fenômeno estudado, ou seja, a impossibilidade de reconhecer os agentes individuais no interior da realidade autônoma coletiva (LEACOCK, 1954, p.61), ou de ver o social como ordem privilegiada de realidade ao qual todas as outras ciências deveriam submeter-se, de vez que seus objetos seriam projeções do social (LÉVI-STRAUSS, 1960, p.48), permanecem como aspectos criticáveis nesta primeira fase dos escritos de Mauss.

Sua alçada como grande nome da etnologia acontece com a publicação daquele que foi considerado não apenas sua obra prima, como ponto de inflexão incontornável para a teoria antropológica e precursor do método estrutural (LÉVI-STRAUSS, 1988, p.129), a saber, Ensaio sobre a dádiva. O objetivo primeiro deste estudo era caracterizar um modo de intercâmbio, de troca presente predominantemente em sociedades não mercantis, a troca-dádiva. Encontra-se aí um modelo de troca em que os objetos não possuem valor per $s i$, ou melhor, que seu valor de mercadoria ou utilidade apresentamse praticamente nulos. Um dos grandes passos realizados por Mauss foi ter reconhecido esses objetos - cuja extensão atinge a intercambialidade possível entre pessoas e coisas (VIVEIROS DE CASTRO, 1999, p.174) - em sua natureza intrínseca, ou seja, como símbolos. Nas palavras de Mauss:

As palavras, as saudações, os presentes, solenemente trocados e recebidos, e obrigatoriamente retribuídos sob risco de guerra, o que são, senão símbolos? [...] senão traduções individuais da presença do grupo por um lado, e das necessidades diretas de cada um e de todos, de suas personalidades, de suas inter-relações, por outro? (MAUSS, 1924, p.333-4).

A dádiva, portanto, por exceder a toda e qualquer função utilitária, inscreve-se como um dispositivo no interior do qual a dimensão simbólica da troca e, em última análise, da própria da sociedade se fundamentam. A operação realizada por Mauss rompe profundamente com a lógica durkheimeana, como nos diz Bruno Karsenti:

O que permite a noção de símbolo é a necessidade de ultrapassar a confrontação de realidades hipostasiadas 
ultrajadamente pelas ciências sociais: não existe nessa concepção nem indivíduo nem sociedade, mas somente um sistema de signos que, mediatizando as relações, constrói num mesmo movimento a socialização dos indivíduos e a unificação dos mesmos num grupo (KARSENTI, 1994 apud MARTINS, 2005, p.55).

Desse modo, o símbolo aparece como uma possibilidade de superação da ruptura entre os planos individual e social, fazendo destas esferas um conjunto no qual há gradação, tradução recíproca de seus termos, sob o julgo da agora explicitada lógica simbólica (LÉVI-STRAUSS, 1950, p.16). É neste contexto que Mauss introduz uma categoria seminal para a compreensão do alcance de sua obra, a saber, a de fato social total. Ela inscreve todo e qualquer fato social como imerso no interior de um sistema, ou seja, nada nele é real se não integrado com a totalidade de outras formas de expressão da vida social (Ibidem, p.23). Vejamos as consequências epistêmicas e metodológicas para a análise antropológica.

O primeiro desdobramento desta noção está justamente em pensar a integração da análise de diferentes esferas da observação de campo no interior de uma estrutura global de inteligibilidade. O trabalho do antropólogo, por esta via, seria a de reconstruir a totalidade do pensamento social. Ora, como pudemos observar, a concepção de um centro de dotação de significância para os fenômenos sociais não imediatamente acessível e que fariam com que as análises devessem ser integradas em conjuntos maiores já estava presente na obra de Boas e sua "atividade inconsciente do espírito". Alguns comentadores reforçam essa ligação ao citar que um esboço da noção de fato social total já se encontrava desde cedo da obra de Mauss (LEACOCK, 1954; LÉVISTRAUSS, 1960), como em seu trabalho sobre a integração das instituições entre os Esquimós (MAUSS, 1906). Entretanto, isto teria se devido em essencial pelo contato de Durkheim, e consequentemente, Mauss com a obra de Boas (CAZENEUVE, 1968 apud DUBAR, 1969, p.519), cujas análises foram objeto do curso de Mauss entre 1905-06. Pode-se dizer que além do apreço pela linguística, à época considerada um ramo das ciências sociais, Mauss importa com tal noção uma crítica à metodologia que procede por classificações abstratas, que culmina em Ensaio sobre a dádiva em uma inversão da lógica analítica: ao invés de partir da concretude dos dados de campo para isolar um tipo de fenômeno abstrato observável em mais de uma sociedade, a noção de fato social 
total implica a impossibilidade de se descolar da concretude de vez que ela não analisa mais os fatos como coisas em si, mas como um reflexo da experiência subjetiva do ator social implicado na situação. O fato social total como objeto de análise, portanto, é análogo em seus determinantes ao "modo de pensar primitivo, onde os fenômenos permanecem ao mesmo tempo jurídicos, econômicos, religiosos, e mesmo estéticos e morfológicos” (MAUSS, 1906, p.309). Em outros termos, nos diz Lévi-Strauss:

Uma das diferenças essenciais entre a maneira como nós refletimos e a maneira como aqueles povos refletem, é a nossa necessidade de fragmentar. Aprendemos isso com Descartes: dividir a dificuldade em tantas parcelas quanto forem necessárias, para melhor resolvê-la. O pensamento dos povos chamados primitivos rejeita essa fragmentação. Uma explicação só é válida desde que seja total. Quando procuramos a solução de um problema específico, dirigimo-nos a esta ou àquela disciplina científica, ou então ao direito, à moral, à religião, à arte... Nos povos que os etnólogos estudam, todos esses domínios são ligados. Assim, cada expressão da vida coletiva constitui o que Mauss denominava um fato social total. Ela põe em questão, simultaneamente, todos esses aspectos (LÉVISTRAUSS, 1988, p.145)

Uma importante contribuição de Mauss neste processo de reconstrução dos fatos sociais totais, está na reafirmação da irredutibilidade dos diferentes campos da vida social que se dialogam em outro plano, ou seja, ele nunca forma uma totalidade por simples arranjo de partes descontínuas, mas é folheado, formado por uma quantidade de planos distintos e justapostos. A equação derivada do reconhecimento da impossibilidade de simples objetivação do sistema de pensamento do outro, suposta na noção de fato social total, impõe, por sua vez, um deslocamento de estratégia metodológica adotada por parte do antropólogo. Como aponta Lévi-Strauss, a noção de fato social total não indica "apenas que todo o observado faz parte da observação, mas sobretudo que o observador é ele mesmo parte da observação" (LÉVI-STRAUSS, 1950, p.25). 
Ao redescrever as três obrigações básicas do intercâmbio das sociedades tradicionais - a saber: dar, receber e retribuir - e extrair a lógica da reciprocidade como estruturante do mecanismo da troca-dádiva, Mauss não apenas concebe a regulação própria de um sistema de trocas, como encontra um princípio universal do homem. Em suas palavras:

Veremos a moral e a economia que regem essas transações. E, como constataremos que essa moral e essa economia funcionam ainda em nossas sociedades de forma constante e, por assim dizer, subjacente, como acreditamos ter aqui encontrado uma das rochas humanas sobre as quais são construidas as nossas sociedades, podemos deduzir disso algumas conclusões morais sobre alguns problemas colocados pela crise do nosso direito e da nossa economia [.... (MAUSS, 1925, p. 188 - grifo теи).

Foucault lê tal empreitada como responsável pela operação de um colapso na hierarquia estabelecida pela ciência do século XIX entre diferentes sociedades, ou seja, a teoria maussiana produziria efeitos que desestabilizariam a sedimentação histórica entre níveis e graus de cultura, a partir da demonstração de que o fenômeno presente em sociedades nativas teria estatuto de eficaz nas formas de troca estabelecidas nas sociedades modernas, mesmo que com um baixo índice de predominância (Cf. RICHMAN, 2002, p.30). A ruptura epistemológica tem como consequência, na metodologia de análise, o fato de que ao tocar em estruturas universais, nenhum dado observado em campo deveria ser visto como novo, o antropólogo deveria "aspirar uma atitude de exotismo zero" (MEHLMAN, 1972, p.21). Ao retirar dos parâmetros de análise a primazia da história em prol de um campo psicossocial, Mauss, no campo da teoria, e Malinowski, na etnografia, estabelecem uma nova era nas ciências sociais.

Como aponta Lévi-Strauss, a impossibilidade de objetivação do fato social total, derivada da noção de inconsciente como reduto estrutural de leis que regulariam a efetivação dos mais diversos fenômenos, coloca, por um lado, o problema da garantia de apreensão dos dados, ou seja, como aferir que sua análise está de acordo com a experiência dos povos estudados, que não é simples projeção de sua forma de vida sobre a análise dos dados, por fim, como acessar esta alteridade cuja apreensão está vetada a todos os envolvidos na experiência. No entanto, por outro lado, a leitura de Mauss da 
noção de fato social total apresenta uma solução para o problema por ela posto: para apreender um fato social, de modo total, é necessário que o tomemos como se vivêssemos o fato da mesma maneira que o ator social aí envolvido. Sua apreensão tem na experiência subjetiva do observador uma instância privilegiada, "quando se põem em ação a totalidade da sociedade e de suas instituições” (MAUSS, 1924, p.309). O etnólogo não apenas tem a sua sensibilidade ou seu olhar modificado por tais lições de Mauss $^{7}$, como vê-se diante de um universal, para o qual ele e o indígena representam duas versões de modos de vida possíveis para uma mesma lógica simbólica. Entretanto, sem acesso direto a tal realidade, o antropólogo deve objetivar promover um desdobramento ilimitado de si, das coordenadas que determinam sua experiência como um todo (LÉVI-STRAUSS, 1950, p.26).

Com tal formulação, Mauss estabelece uma proximidade entre a formação do etnólogo e do psicanalista. Em um giro análogo ao produzido por Freud quando da emergência do método psicanalítico, o antropólogo concebe que a operação de leitura e extração de dados de um determinado campo, implica a experiência subjetiva do pesquisador. Portanto, diferente da posição pretensamente científica da pesquisa experimental, que estabelece de partida uma total cisão entre o sujeito e seu objeto, a pesquisa em psicanálise e em etnologia, compreendem que a objetividade de seu campo não deve ser dada à revelia das subjetividades implicadas em todas as esferas de suas pesquisas. Com Lévi-Strauss, poderíamos ainda nos questionar se tal esforço de “desdobramento ilimitado de si”, não aproximaria a produção de conhecimento de tais disciplinas do conhecimento estabelecido pelo xamã, enquanto mediador de mundos heterogêneos e inconciliáveis.

O postulado maussiano, portanto, abre sua teorização à sustentação de uma atitude empírica por parte do observador que marca a superação, no campo da etnologia, da repugnância de Durkheim pela etnografia (LÉVI-STRAUSS, 1960, p.48). Em busca de acessar esse modo outro de experienciar os fatos sociais, Mauss, assim como Boas,

\footnotetext{
${ }^{7}$ Um dos mais célebres alunos de Mauss, Louis Dumont, realiza o seguinte testemunho acerca da transformação da sensibilidade do observador preconizada pelo seu ensino: "Outro dia, num ônibus, percebi de repente que não olhava para os meus companheiros de viagem como de costume; alguma coisa havia mudado em minha relação com eles, em minha maneira de me situar com relação a eles. Não havia mais 'eu e os outros'; eu era um dele. Durante um longo momento me perguntei pela razão dessa transformação curiosa e repentina. De repente ela me surgiu: era o ensinamento de Mauss. [...] o indivíduo de ontem sentia-se social, percebera sua personalidade como ligada à linguagem, às atitudes, aos gestos, cuja imagem era devolvida pelos vizinhos. Eis o aspecto humanista essencial de um ensino em etnologia. (DUMONT, 1971, p.55).
} 
eleva as representações conscientes do indígena ao estatuto de significância para a análise mais profunda. $\mathrm{O}$ inconsciente, escreve Lévi-Strauss, seria somente acessível no contato, conflituoso, sempre faltante, entre o objetivo e o subjetivo, entre mim e outrem. Dentre as categorias promovidas por Mauss, encontramos o fato mítico ocupando uma posição especial em suas análises.

Encontramos desde o Esboço de uma teoria geral da magia, uma consideração particular pelas narrativas míticas, por duas motivações básicas: a primeira, de ordem estatística, decorre da constatação do "lugar considerável das tradições orais na vida das populações do mundo inteiro e constituem uma das seções principais do folclore" (MAUSS, 1904, p.69); já a segunda, interna ao seu argumento central da eficácia social da magia, está na observação que "contos e lendas não apenas se configuram como jogos de imaginação, alimento tradicional da fantasia coletiva; sua constante repetição, durante longos serões, mantém um estado de expectativa, de temor, que pode, ao menor choque, produzir ilusões e conduzir a atos" (Ibidem). No entanto, outra é a posição em seu escrito mais famoso. Neste momento, como escreve a Radcliffe-Brown, Mauss reconhece o fato mítico como carecendo de um estudo mais detalhado, pois que esteja "ligado aos fatos sociais, alguns já lograram demonstrar, mas não os detalhes de sua construção. Ademais, as questões de mitologia são as mais difíceis” (MAUSS, 1925, p.240). Em especial no texto sobre a dádiva, é surpreendente a grande monta de narrativas míticas de que Mauss se vale. O mito aqui aparece como elemento privilegiado de acesso às categorias nativas de representação. $\mathrm{O}$ mito assume em uma teoria etnológica - senão pela primeira vez, posto que já viramos seu uso em Boas, mas certamente com muito maior expressão e volume - um valor primordial para a análise antropológica, fato derivado de uma metodologia que busca acessar o nível estrutural e inconsciente dos fatos sociais.

Como veremos à frente, a obra de Mauss foi primordial para o projeto lévistraussiano de reformulação dos padrões epistêmicos em antropologia. No entanto, podemos desde já notar que dentre inúmeros elogios à renovação da teoria e importações conceituais da obra de Mauss, uma crítica persistiu à seu empreendimento: justamente pelo fato de elevar a um fenômeno de primeira ordem as representações conscientes, enquanto via de acesso às categorias inconscientes do pensamento indígena, posto que estão estruturalmente ligadas, Mauss não teria levado tão longe quanto desejado seus procedimentos, deixando muitas de suas análises recaírem ao 
nível descritivo (LÉVI-STRAUSS, 1952, p.305). Outra implicação desta falta metodológica de Mauss, está na dificuldade de conceber as categorias antitéticas extraídas de seus estudos (mana, hau), não apenas como ligando termos distintos, mas como "reflexo subjetivo da necessidade (exigência) de totalidade não percebida" (LÉVI-STRAUSS, 1950, p.40) como termos inerentes ao sistema, ou, no vocabulário extraído da fonologia estrutural, como um símbolo zero. Veremos as implicações desta crítica de Lévi-Strauss na sua releitura da análise dos mitos.

\section{Lévi-Strauss e a revisão do estatuto epistêmico de Totem e Tabu: o mito e seu valor metodológico}

Observamos no presente capítulo, como Totem e Tabu representa a expressão máxima da incidência da produção antropológica na obra freudiana. Com vistas a expandir o escopo de ação dos resultados a que chegara em suas pesquisas - no campo da clínica psicopatológica - acerca dos fatores constitutivos (universais) da subjetividade humana, Freud lança mão de inúmeras referências etnográficas para formular o que seria seu equivalente na esfera coletiva. Entretanto, como vimos, a lógica freudiana de articulação da ordem constitutiva é indissociável de uma marca, de um registro histórico. Por esta via, a construção da hipótese da origem global das instituições sociais e da cultura presente em Totem e Tabu, enquanto uma versão do mito de Édipo, inscreve na história um conjunto de eventos arcaicos que teriam valor decisivo para a determinação da configuração atual dos fatos humanos.

Freud deparou-se, no contexto da produção antropológica do início do século $\mathrm{XX}$, com uma ampla rejeição de seus termos. E isso a despeito do grande esforço realizado por uma verdadeira interlocução com as ciências sociais, ao sustentar no seio de sua teorização um postulado que, a um só tempo, respondesse pela lógica do universal e do histórico - como bem denotado em sua expressão "mito científico", ou "mito histórico". Entre os principais teóricos da antropologia contemporâneos ao psicanalista vienense, como vimos, Totem e Tabu fora duplamente descartado: enquanto história, com pretenso estatuto científico, pela falta de consistência metodológica tanto na escolha de suas referências, quanto no modo de extração e produção de resultados a partir de suas premissas; e enquanto mito, posto que, se encontramos uma valorização do fato mítico, em especial por Boas e Mauss, é apenas com a condição de ser 
caracterizado como um fato sociolinguístico que serviria como meio parcial de acesso a regras universais, portanto, enquanto um produto nativo extraído in loco - mas nunca como uma narrativa construída dentro de um discurso científico. Por esta via, a teoria social de extração psicanalítica, fora deixada em um segundo plano, em prol da representação da psicanálise como uma psicologia individual que, se não contribuiria para as construções globais da antropologia, timidamente seria requerida para tratar de fatos particulares dos sujeitos.

Entretanto, no início dos anos 50, o silêncio a que a antropologia social pósMalinowski fez com relação à psicanálise finalmente foi rompido. $\mathrm{O}$ surgimento dos trabalhos do antropólogo francês Claude Lévi-Strauss incidiu sobre a relação entre as duas disciplinas de forma a marcar um ponto de torção que reverbera até hoje no modo como a antropologia social encara a psicanálise. A chave de leitura do clássico freudiano Totem e Tabu, deslocou-se do simples par binário de aceitar/recusar suas referências e teses, para lhes restabelecer seu lugar de direito: as proposições de Totem e Tabu não deixam de ter seu lugar entre as grandes teorias sobre a origem da cultura, pois antes de atestarem fatos históricos, elas se valem de recursos teóricos díspares, mesmo ultrapassados (Cf. FREUD, 1927) para forjar uma hipótese final que segue a estrutura de um mito, ou melhor, que veicula uma verdade na medida em que se constrói no mesmo plano epistêmico possível a qualquer formulação sobre esse momento originário, o plano mítico. Sobre esta obra freudiana, Lévi-Strauss sintetiza sua interessante perspectiva na seguinte passagem:

A partir do momento em que se pretendia explicar certos traços atuais do espírito humano por um acontecimento ao mesmo tempo historicamente certo e logicamente necessário, era permitido, e mesmo prescrito, tentar reconstituir, escrupulosamente a sequencia dos fatos. O malogro de Totem e Tabu, longe de ser inerente ao propósito do autor, prende-se mais à hesitação que o impediu de se prevalecer até o fim das consequências implicadas nas suas premissas. Era preciso ter visto que fenômenos que se referem à estrutura mais fundamental do espírito humano não teriam podido aparecer de uma vez por todas. Repetem-se inteiramente no interior de cada consciência e a explicação de que dependem pertence a uma 
ordem que transcende ao mesmo tempo as sucessões históricas e as correlações do presente. A ontogênese não reproduz a filogênese, ou o contrário. As duas hipóteses conduzem às mesmas contradições. Só se pode falar de explicação a partir do momento em que o passado da espécie torna a representar-se em cada instante no drama indefinidamente multiplicado de cada pensamento individual, porque sem dúvida ele próprio não é senão a projeção retrospectiva de uma passagem que se produziu, porque se produz continuamente. (LÉVI-STRAUSS, 1949a, p.535)

Primeiro a reconhecer em Totem e Tabu a lógica mítica - contribuição central para a leitura efetuada por Lacan - Lévi-Strauss reposiciona a apreensão da teoria freudiana no interior da etnologia por dois vieses: primeiramente, o antropólogo francês retira dos postulados de Totem e Tabu o que considera uma herança do método para o estabelecimento de uma ciência à época de Freud, a saber, a dimensão histórica. Em outros termos, Lévi-Strauss relê as teses freudianas com vistas a extrair um princípio de estrutura, portanto, atemporal, que livraria a obra das críticas à pretensão do psicanalista de encontrar aí a lógica inequívoca de um fato inscrito nas origens históricas do homem.

Em segundo lugar, decorrente desta concepção de estrutura e do papel da lógica simbólica sobre os fatos humanos, Lévi-Strauss reconhece o valor epistêmico e metodológico do recurso ao mito na construção de uma disciplina científica. Dos autores analisados, extraímos quatro distintas posições sobre o lugar do mito em suas teorizações: em Malinowski, o mito fora relegado a um estatuto secundário, como uma formulação que apenas seria digna de atenção se vinculada à análise funcional das instituições observadas em campo; Rivers compreende a temática do mito como responsável por uma via de acesso a fragmentos narrativos de eventos passados que deveriam ser reconstituídos de modo a reestabelecer, ordenar o continuum histórico pelo mito veiculado; com Boas e Mauss o mito recebe uma consideração especial enquanto via de acesso para as categorias inconscientes do espírito, entretanto, do lado de Boas, elas são consideradas como representativas dos modos universais de construção e assimilação da cultura - em uma perspectiva diacrônica, portanto - enquanto do lado de Mauss, as narrativas míticas são vistas como responsáveis pela expressão de certas categorias nativas, a partir dos quais os fatos sociais receberiam sua significação global. 
É neste contexto que surge o pensamento de Lévi-Strauss que, por seu poder de sintetizar e conjugar posições tão heterogêneas, representa a emergência de um ponto de virada na ciência antropológica. No interior deste movimento, o antropólogo francês reestabelece não apenas valor central do fato mítico para as análises de sua disciplina, como realiza uma verdadeira revolução no diálogo com a psicanálise.

Ao reintroduzir Totem e Tabu na discurso antropológico, Lévi-Strauss colocase na mesma linhagem de Freud, que primeiramente fora responsável pelo reconhecimento do papel metodológico do mito como instrumento de formalização de uma teoria sobre o universal do homem. A obra freudiana, segundo o antropólogo, ao lançar mão da hipótese mítica para a origem da cultura, encontrara uma forma de exprimir os determinantes constitutivos dos fatos humanos, daquilo que rege e institui, de forma negativa, a ordem da cultura, a saber, a proibição do incesto. Em seus termos:

As satisfações simbólicas nas quais, segundo Freud, se expande o sentimento de incesto não constituem, portanto, a comemoração de um acontecimento. São outra coisa e, mais do que isso, são a expressão permanente do desejo de desordem, ou, antes de contraordem. [...] Os caracteres do passado só tem valor explicativo na medida em que coincidem com os do futuro e do passado. (LÉVI-STRAUSS, 1949a, p.536).

A leitura de Totem e Tabu enquanto um mito, portanto, recebe de Lévi-Strauss um estatuto de primeira grandeza na teoria antropológica. Ele se instituiria como uma forma de matriz simbólica das condições de possibilidade, sempre atuantes na configuração das expressões da cultura, de surgimento da ordem humana. Ao lê-lo como um mito, portanto, insere a obra freudiana em um registro de sincronicidade que permitiria à antropologia rever suas premissas. Como veremos no próximo capítulo, a proibição do incesto, recebe de Lévi-Strauss uma posição central para o delineamento do campo antropológico, posto que ela seria a um só tempo, um construto cultural, portanto, da esfera do particular, que se encontraria presente na totalidade das sociedades humanas, participando, por essa via, da universalidade própria à ordem da natureza. Totem e Tabu, como o lê Lévi-Strauss, apresentaria em seus termos a problemática constitutiva do fazer antropológico: como e em quais termos estabelecer um conjunto de postulados que trate da complexa articulação entre o universal e o particular, Natureza e Cultura. 
Vejamos quais os termos em que se deu o contato da obra lévi-straussiana com a psicanálise, assim como as incidências do mito enquanto objeto privilegiado de análise e como método de acesso à lógica estrutural. 


\section{CAPÍTULO 3}

A experiência intelectual de Claude Lévi-Strauss, como já observamos, é considerada responsável por engatar uma profunda revolução que não apenas incide sobre o campo da antropologia social, mas inaugura no cenário intelectual francês aquele que talvez possa ser considerado o maior movimento interdisciplinar de reflexão e reformulação dos padrões epistêmicos das ciências ditas humanas no século XX, a saber, a vaga estruturalista.

A linguística estrutural, no papel de carro-chefe deste movimento (DOSSE, 1992, p.101), foi uma das primeiras ciências sociais a estabelecer um método que operava a extração de uma "realidade outra", inteligível, a partir de elementos sensíveis. Deste modo, tornava possível uma análise em termos de necessidade (LÉVI-STRAUSS, 1945, p.47) a fenômenos até então entregues à marca de pura arbitrariedade, em termos mais específicos, ela extraía da concretude e sensibilidade das palavras "a realidade fonética do fonema e deste, a realidade lógica dos elementos diferenciais" (JAKOBSON, 1938 apud LÉVI-STRAUSS 1949d, p.35). Assim, indissociável de uma "nova filosofia transcendental, onde os lugares prevalecem sobre aquilo que os preenche" (DELEUZE, 1971, p.226), a linguística fundava o método estrutural que trazia grandes promessas de formalização aos mais distintos campos.

Lévi-Strauss foi, senão o primeiro fazer sua disciplina dialogar com a linguística, decerto o primeiro a compreender o alcance do método para todas as "ciências vizinhas, as ciências sociais" (LÉVI-STRAUSS, 1945, p.46), que há tempos aspiravam a um estatuto de cientificidade; levando, a partir daí, e eis sua originalidade, o pressuposto do caráter estrutural dos fenômenos coletivos "imperturbavelmente às últimas consequências" (POUILLON, 1956 apud LÉVI-STRAUSS, 1958, p.9). O projeto lévi-straussiano poderia bem ser resumido como um contínuo desvelar da “ordem [significante existente] atrás da [aparente] desordem" (LÉVI-STRAUSS, 1978, p.23).

Entretanto, é patente desde o início de sua obra a híbrida posição de LéviStrauss frente às principais escolas de antropologia, representadas em essência pelos teóricos que vimos no capítulo anterior. Com Malinowski, assume a importância do 
refinamento do método de pesquisa etnográfica, assim como a necessidade de uma análise sincrônica dos fatos sociais; a partir de Boas, herda o interesse pela atividade inconsciente do espírito em sua correlação com a linguagem, assim como a relação entre natureza e cultura; de Rivers, a relação entre os universais psicológicos e determinantes culturais, em especial no que permite reler o referencial histórico-geográfico; e, finalmente, desde Mauss, extrai as consequências epistêmicas e metodológicas do conceito de fato social total, assim como "retoma a problemática boasiana da passagem da natureza à cultura em termos sociopolíticos, diretamente inspirada na noção maussiana de reciprocidade" (VIVEIROS DE CASTRO, 1996, p.305). Consideremos o movimento inicial do projeto antropológico fundado por Lévi-Strauss.

\section{Lévi-Strauss e o projeto de uma antropologia estrutural}

Sua obra inaugural, aquela que o lançou como grande nome da intelectualidade francesa foi sua tese de doutoramento, publicada em 1949, As Estruturas Elementares do Parentesco. Nas palavras de Didier Eribon, ela representa uma "extensão dos problemas dos sistemas de casamento do escrito de Mauss, Ensaio sobre a dádiva, reinterpretado partir do método estrutural de que a linguística lhe fornecia um modelo organizado" (LÉVI-STRAUSS, 1988, p.130). Entretanto, mais que simplesmente contribuir com uma problemática pontual, As Estruturas Elementares revolucionaram o campo da antropologia justamente por se valer de um método de análise dos fenômenos de parentesco análogo ao desenvolvido pela linguística. Em suas palavras:

Entre todas as ciências sociais só uma chegou ao ponto em que a explicação sincrônica e a explicação diacrônica se reúnem, porque a primeira permite reconstituir a gênese dos sistemas, fazendo a síntese deles, enquanto a segunda evidencia sua lógica interna e apreende a evolução que os dirige para um alvo. Esta ciência social é a linguística concebida como estudo fonológica. Ora, quando consideramos seus métodos, e mais ainda seu objeto, podemos perguntar se a sociologia da família, tal como foi concebida neste trabalho, refere-se a uma realidade tão diferente quanto se poderia crer, e se, por conseguinte, não 
dispõe das mesmas possibilidades. (LÉVI-STRAUSS, 1949a, p.533)

A linguística, portanto, respondia por um modelo de análise que permite a articulação entre as dimensões sincrônicas e diacrônicas de uma dado fenômeno em uma chave estrutural, ou seja, sem que fosse necessário recorrer à tradição histórica de análise que busca em "um passado longínquo a razão de ser de uma situação atual” (LÉVI-STRAUSS, 1949a, p.532).

O projeto lévi-straussiano de apreensão dos determinantes universais do homem herda de Boas, como vimos, a consideração pela passagem do estado de Natureza (universal, extemporâneo) ao de Cultura (particular, histórico). O fato etnológico que responde pela dupla determinação é justamente a proibição do incesto e seu correlato, o princípio de exogamia. Segundo o antropólogo, a linguística estrutural, neste contexto, traria uma vantagem frente a empreitada psicanalítica: se Totem e Tabu conjuga tanto uma perspectiva histórica, quanto uma análise do presente que espera alçar o conhecimento do futuro e do passado, o modelo linguístico permite um princípio de universalização que o afasta da dimensão imediata do fenômeno. Em outras palavras, se a psicanálise formulara um mito histórico para "aprofundar a estrutura dos conflitos de que o doente é palco" (Ibidem), a linguística construíra um método que permitiria à análise antropológica redimensionar a construção de seus fatos, e, assim, aproximar, pela relação lógica entre universal e particular, a natureza de objetos tão distantes como a linguagem e as estruturas de parentesco. Nos termos de Lévi-Strauss

Se a proibição do incesto e a exogamia têm uma função essencialmente positiva, se sua razão de ser consiste em estabelecer, entre os homens, um vínculo sem o qual não poderiam elevar-se acima da organização biológica para atingir a organização social, então é preciso reconhecer que linguistas e sociólogos não somente aplicam os mesmos métodos mas se dedicam ao estudo do mesmo objeto. Deste ponto de vista, com efeito, exogamia e linguagem têm a mesma função fundamental, isto é, a comunicação com o outro e a integração do grupo. (LÉVI-STRAUSS, 1949a, p.534) 
Ao se especificarem como fenômenos de linguagem, tanto a língua, quanto a exogamia e os sistemas de trocas dela derivados, Lévi-Strauss reconhece a origem comum desses dois campos na estrutura própria do que será denominado, mais uma vez por influência da obra boasiana, de atividade inconsciente do espírito. Deste fato decorre que, no percurso de formalização de ambos os campos, o pesquisador tratará de abstrair, para além das heteróclitas manifestações fenomênicas, relações lógicas de “correlação e oposição” (LÉVI-STRAUSS, 1949d, p.36). Estas relações que tomarão a forma, como veremos à frente, de modulações e recombinações dos elementos em uma “ordem topológica, um espaço inextenso, pré-extensivo, puro spatium constituído cada vez mais como ordem de vizinhança" (DELEUZE, 1971, p.115)

Entretanto, vale ressaltar que a grande revolução da obra inicial de LéviStrauss foi propiciada pela não redução e sobreposição dos elementos constitutivos mínimos encontrados nos campos da língua e do parentesco. À diferença da metalinguística americana, como a de Edward Whorf, Lévi-Strauss não se valerá dos resultados a que os estudos linguísticos chegaram, mas sim, do seu método. Em suas palavras:

Tanto os sistemas de parentesco como os fonológicos são elaborados pelo espírito no estágio do pensamento inconsciente. A recorrência em regiões afastadas do mundo leva a crer que tais fenômenos resultam de leis gerais, mas ocultas [...] em uma outra realidade, os fenômenos do parentesco são fenômenos do mesmo tipo que os fenômenos linguísticos. (LÉVI-STRAUSS, 1945, p.46).

Desta maneira, ao ressaltar uma "certa correlação" entre o distinto "quadro de fonemas e sistemas de parentesco" (LÉVI-STRAUSS, 1945, p.49), Lévi-Strauss tornava crível pensar numa ordem de determinação de toda realidade social possível, então analisável através de distintas estruturas.

Eis a matriz que abre em seu pensamento a possibilidade de reconsiderar a análise de temas problemáticos no interior de toda a história da antropologia, desde os sistemas de parentesco, até o totemismo, as curas xamânicas, as representações gráficas e, em especial, aquele que foi o tema ao qual dedicou grande parte de sua obra, a mitologia. 
O presente capítulo visa retraçar os movimentos na obra lévi-straussiana de assimilação e desenvolvimento da análise do fenômeno mítico. A originalidade de sua empreitada é reconhecidamente influenciada pelo contato com a psicanálise - enquanto projeto epistemológico e prática de tratamento - em especial pela possibilidade de articulação destes planos no interior da edificação de sua teoria. Antes de percorrer o movimento inverso, de retomada da influência decisiva das primeiras formulações do antropólogo para o projeto lacaniano de retorno a Freud (Cf. ZAFIROPOULOS, 2004), analisaremos como as trocas com a teoria psicanalítica permitem-nos apreender diferentes momentos de sua extensa jornada através da análise dos mitos.

\subsection{A dupla via de inserção da psicanálise na obra lévi-straussiana}

A psicanálise, como dissemos, se insere na obra lévi-straussiana por um duplo viés que extrapola a tradição de comentários a Totem e Tabu. Ela portaria, de um lado, um nível de inteligibilidade na construção de seus "fatos" que serve de inspiração metodológica a todo o projeto lévi-straussiano - o que faz com que este renda-lhe homenagens até o fim de sua vida, por mais que sua posição sobre as teses freudianas encontre algumas reviravoltas (LÉVI-STRAUSS, 1988; STRAUSS, 2008). Seu contato com a obra de Freud se dera ainda adolescente, como relatado ao historiador François Dosse: Li na época, entre 1925 e 1930, tudo o que estava traduzido de Freud, que desempenhou, portanto, um importante papel na formação do meu pensamento" (DOSSE, 1992, p.164). Análoga ao procedimento linguístico, a psicanálise ampliou em seu campo a possibilidade de operar por uma redução semiológica a fatos que antes eram entendidos como dotados da marca do puro acaso, da arbitrariedade, fato que como vimos será central na revisão lévi-straussiana do escopo de análise da antropologia social. O potencial epistemológico da leitura psicanalítica, se já foi salientado por Rivers e Mauss, sob a pena de Lévi-Strauss leva o modo de interpretação do fato antropológico como desdobrado entre sua faceta fenomênica e sua posição dentro de um sistema lógico que poderia ser reconstituído se bem determinado seu nível de inteligibilidade.

Por outro lado, Lévi-Strauss foi um dos primeiros antropólogos, decerto o mais relevante, a levar em consideração a dimensão da lógica mítica no interior da análise do tratamento psicanalítico. Mais que simplesmente explicitar as determinações estruturais 
para a composição de uma narrativa mítica - abordagem associada à perspectiva anterior - temos nesta empreitada uma análise das modificações de sistemas estruturados, ou como na prática eles se articulam e infligem transmutações entre si. $\mathrm{O}$ campo do mito, neste contexto, está indissociado de sua função em uma prática ritual. Tal vereda leva Lévi-Strauss à comparação entre as práticas de tratamento xamânicas e psicanalíticas com vistas às suas posições no interior de um sistema mítico, como podemos ver na seguinte passagem:

Tratar-se-ia, em ambos os casos, de induzir uma reorganização estrutural, levando o paciente a viver intensamente um mito, ora recebido, ora produzido, análoga àquela cuja formação se quer determinar no nível do corpo. (LÉVI-STRAUSS, 1949b, p.217 - grifo meu)

A dupla inscrição realizada pela leitura do antropólogo francês, que abre estas duas frentes de articulação entre psicanálise e antropologia, não comporta para ambas, no entanto, o mesmo peso nos desenvolvimentos futuros de sua obra. As duas têm início entre o fim da década de 40 e começo da próxima, porém a primeira via, a de análise das estruturas míticas em correlação com a universalidade da atividade inconsciente do espírito - de extração boasiana - acompanhará Lévi-Strauss por mais de trinta anos, passando pela construção de um método de análise deste fenômeno discursivo (expresso pela operação de extração da noção de mitema) (LÉVI-STRAUSS, 1952), de um modelo de transformação de narrativas (fórmula canônica do mito) (LÉVI-STRAUSS, 1955), assim como seu papel capital para a explicitação da sistematicidade do chamado pensamento selvagem (também denominado mito-poético) (LÉVI-STRAUSS, 1962). A outra via, de sua inserção nos sistemas de tratamento - inspirada na vertente de Rivers praticamente não segue para além destes primeiros anos, haja vista a presença de um déficit de grandes desenvolvimentos sobre a noção de rito, de sacrifício ou xamanismo em sua obra. Se por um lado, a noção maussiana de fato social total articula as duas vertentes em Lévi-Strauss - haja vista, a integração da análise de um fato etnológico no conjunto de expressões culturais - por outro, como bem aponta Viveiros de Castro (2004), o antropólogo preferiu o sistema totêmico em detrimento do esquema sacrificial, ou seja, suas análises focaram muito mais na correlação e homologia entre sistemas de significação que em sua relação metonímica, de mútua transformação. 
Diante deste desequilíbrio, torna-se explícito um dos fatores de distanciamento que a antropologia derivada da obra lévi-straussiana tomou frente à psicanálise. Se os escritos do antropólogo que analisaram as condições do tratamento psicanalítico, em correlação com o xamânico, são considerados uma grande contribuição à psicanálise contribuição esta que faz $O$ feiticeiro e sua magia e $A$ eficácia simbólica serem até hoje uma referência nos programas de formação psicanalítica - não podemos dizer que recebam o mesmo reconhecimento daqueles que buscam em Lévi-Strauss um modelo metodológico do fazer antropológico. Entretanto, ao retornar a tais escritos, em especial A eficácia simbólica, teremos oportunidade de retomar em detalhes o valor de tal análise para o conjunto da obra lévi-straussiana, assim como a seu projeto de formalização dos fenômenos sociais, que encontrará sua maior realização e expressão no desenvolvimento sobre os fundamentos da estrutura e do plano de ação mítico. Portanto, a hipótese fundamental que buscarei sustentar no decorrer deste capítulo é a de que a leitura da estrutura mítica, tal qual apresentada por Lévi-Strauss a partir da década de 50, não deve ser descontextualizada das premissas que fizeram com que o antropólogo a introduzisse na análise dos rituais de cura. Em outros termos, que o modelo de estrutura de transformação das narrativas míticas apresenta em seu cerne a dimensão da experiência e da história. Tomemos os primeiros passos o antropólogo no estudo dos mitos.

\section{A eficácia simbólica e seus desdobramentos a uma teoria do mito}

\subsection{As origens lógico-históricas do escrito}

A temática proposta, na obra de Lévi-Strauss, remete-nos primeiramente ao ano de 1949. Este é marcado pelo advento de dois grandes artigos que testemunham os avanços no pensamento do antropólogo francês em prol da especificação daquela condição que tornava seu projeto pelo parentesco, em As Estruturas Elementares do Parentesco, "possível e necessário" (GOLDMAN, 2004, p.58), a saber, a função simbólica. São estes os já referidos O feiticeiro e sua magia e seu par indissociável, homônimo do grande conceito em jogo na época, A eficácia simbólica. Ao tratar da função e eficácia do símbolo como uma propriedade “indutora entre estruturas formalmente homólogas que podem se edificar com materiais diversos - processos 
orgânicos, psiquismo inconsciente, pensamento consciente" (LÉVI-STRAUSS, 1949b, p.217), o antropólogo francês tratava de marcar o irredutível excesso de significações do universo simbólico em relação ao mundo a significar (LÉVI-STRAUSS, 1950, p.43). Além do papel do escrito em seu projeto, como caracterizaremos à frente, é digno de nota marcar a ordem contingencial e extrateórica na escolha de seu objeto: neste ano, 1949, Lévi-Strauss fora nomeado para suceder a Marcel Mauss na $5^{\text {a }}$ seção de estudos da École Pratique des Hautes Études (LÉVI-STRAUSS, 1988), dedicada às ciências da religião.

No plano geral d'A eficácia simbólica, encontra-se a bem conhecida análise de um canto kuna (HOLMER; WASSEN, 1947). Este narra a cura xamânica de uma parturiente que apresenta uma excepcional complicação no momento de dar à luz seu filho. O texto é a transcrição de um canto que relata as ações e cantos entoados pelo xamã ao longo de seus procedimentos. Para um leitor ocidental, pouco instruído nas formas nativas de tratamento, pode-se ainda dizer que o caráter dramático, e mesmo fantástico da cena emerge quando, diante de um quadro que inspira cuidados que determinarão a vida ou a morte da parturiente e seu bebê, o protagonista da cura, o xamã, munido de seu impávido chocalho e seu portentoso cachimbo, intervém ritualmente dançando e cantando. Antes de entrarmos no escrito lévi-straussiano, um importante dado será de auxílio para nos a acercarmos da qualidade da fonte primária na qual o antropólogo extrai o canto em torno do qual giram suas análises, assim como das suas condições de receptação e transmissão.

Desde a década de 20, um grupo do Museu Etnográfico de Gothenberg, liderado por Erland Nordenskiöld, realizava suas pesquisas de campo entre os indígenas guajiro da região do Panamá, entre os quais se encontram os kuna. O grupo sueco contava com o índio kuna Guillermo Haya como tradutor e informante principal, este que foi por muitos anos secretário de Néle de Kalunda, um homem versado nas tradições de seu povo e que primeiramente narrou a versão que chegou a Gothenberg. No entanto, quando convocado em 1938 pelo etnógrafo Henry Wassén, sucessor de Nordenskiöld, e pelo linguista Nils Holmer a gravar um registro do canto, Haya o coletou de Huauquine, um homem instruído neste canto. Dessa forma, um primeiro ponto a notar, é que o canto é um relato tradicional de um nativo e não a descrição de um etnógrafo que presenciou a cena enquanto tal. 
No interior deste contexto, um fato seminal deve ser pontuado: as transcrições das partes deste longo canto, que totaliza 535 versos em 18 páginas, foram enviadas à Suécia à medida que eram finalizadas por Haya. A primeira publicação de uma análise do canto se deu em 1947 sob o título de Mu-Igala or the Way of Muu: A Medicine Song from the Cunas of Panama, e serviu de referência fundamental para a análise encontrada n'A eficácia simbólica, a ponto de constar permanentemente em sua bibliografia desde a primeira versão em 1949. Entretanto, em 1952 Haya enviou uma carta, explicando que a II Guerra Mundial impossibilitou a correspondência entre Panamá e Europa e enviou o último terço do canto (121 versos), assim como a escrita pictórica (picture writing) de todo o canto, junto com outros materiais. Holmer e Wassén fizeram, então, uma nova publicação na qual era adicionados, além do canto completo, as gravuras nativas e comentários linguísticos e etnográficos acerca de todo o conjunto. O título desta vez foi The Complete Mu-Igala in Picture Writing. A Native Record of a Cuna Medicine Song (HOLMER; WASSÉN, 1953). Portanto, um segundo ponto a notar é o fato de que na obra em que Lévi-Strauss se baseou para apresentar de forma mais concreta sua posição frente ao xamanismo e seus dispositivos de cura, há uma incompletude primordial que o impossibilitou de lidar com um verdadeiro relato de tratamento, o que não é sem consequências tanto para a formulação de sua teoria, como para a consequente tentativa de sustentação frente aos novos dados. Analisaremos à frente a decorrência deste fato histórico. Mas antes, vejamos como se deu a argumentação do antropólogo para o entendimento do papel do mito no interior do tratamento xamânico.

\subsection{O relato de cura e seus elementos narrativos}

O canto do xamã se inicia com a descrição minuciosa do contexto preliminar à sua convocação. Neste tem lugar primeiramente o relato da aflição da parteira diante de seu insucesso, assim como a sua ida ao local onde se situa o xamã, o caminho realizado pelos dois até a casa da parturiente, a chegada e preparativos mínimos, que vão desde a fumigação de cacau e feijão queimados até as invocações dos espíritos e confecções das imagens sagradas que auxiliarão o xamã (LÉVI-STRAUSS, 1949b, p.202). Na análise de Lévi-Strauss, uma característica que este ressalta acerca da estrutura da narrativa é o fato de a ação do xamã, propriamente dita, contra o agente provocador, ocupar uma parte ínfima na totalidade do relato, em comparação ao desenvolvimento dos eventos 
preliminares e posteriores ao enfrentamento da doença em seu local específico. A razão deste modo de proceder, segundo o antropólogo, está na mediação complementar, operada pela prática xamânica, entre uma ação local e uma repetição ritual, sem a qual, todo o conjunto seria reduzido ou a efeitos de embuste ou à mera abstração (LÉVISTRAUSS, 1949b, p. 206). Como veremos, a estrutura paralela entre mito e operações rituais são conjugadas especialmente com vistas a produzir um efeito no corpo da paciente, experiência que Lacan posteriormente também assimilará à dinâmica do real.

Busca-se por esta via uma reintegração das dores da doente em uma "narrativa coletiva, maior" (Ibidem, p.209) na qual ela e o socius possam se reconhecer, ou melhor, reconhecer a tensão de forças mágico-políticas que estão em jogo na determinação da situação-questão. No caso presente, é Muu, entidade que reside no/se confunde com o útero, que cedeu aos seus próprios caprichos e está excedendo às suas atribuições usuais.

No entanto, chama a atenção de Lévi-Strauss o fato de que uma situação que coloca em evidência procedimentos eminentemente psicológicos tenha uma eficácia para questões relacionadas a patologias orgânicas. Recusando os argumentos simplistas de que tal fenômeno se justificaria pela sua própria existência ou de que seria fruto de embuste, ele encaminha sua resposta para o nível de imbricação entre as duas esferas, levando à formulação de que, através dos efeitos do símbolo no corpo, o xamã realizaria uma "manipulação psicológica do órgão doente".

A noção de eficácia simbólica como garantidora desta articulação teve, para seu projeto de análise da inscrição e determinação global do simbólico nas séries classificatórias, um papel central no sentido de mostrar - da mesma maneira como Freud estabelecera desde Tratamento psíquico, tratamento anímico (1890) - como tal determinação simbólica se realizava até mesmo no interior da vivência corporal. $\mathrm{O}$ passo seguinte no conjunto de sua obra - de explicitação da amplitude desta determinação - se dará através de uma investigação do tipo manifestação na qual o espírito teoricamente teria mais liberdade para agir, a saber, o mito. Este passo está em consonância com a decorrência lógica da proposição quase aforismática de Tylor, na qual este diz: "se há lei até mesmo nos mitos, então deve haver lei em toda parte". Mas retomemos a cura ritual xamânica, tal como apresentada por Lévi-Strauss. 
Todo o procedimento opera por uma narrativa recitada pelo xamã no interior de um ritual protagonizado miticamente por este, seus ajudantes espirituais (os nuchus) e os agentes problemáticos. De forma sucinta, ela inicia por uma descrição reiterativa de elementos secundários presentes desde o descobrimento da doença até a convocação e chegada do xamã. Como pode-se ver neste trecho:

A parteira dá uma volta dentro de casa;

A parteira procura contas;

A parteira dá uma volta;

A parteira coloca um pé diante do outro;

A parteira toca o solo com o pé;

A parteira coloca o outro pé adiante;

A parteira abre a porta de sua casa; a porta de sua estala A parteira sai... (Versos 4-11) (LÉVI-STRAUSS, 1949b, p.208)

A partir deste ponto a narrativa, sob a forma musical, é conduzida em um ritmo crescente até que, num segundo momento, quase ofegante, ele passe a alternar em sua fala temas míticos e "concretos", de modo a abolir a distinção entre ambos. Em seguida, a partir da narrativa da jornada fantástica do xamã, há a dissolução dos obstáculos ao parto, através de um embate aos excessos de $M u u$, e por fim, o retorno à cena do parto do xamã e seus espíritos-auxiliares, retorno este tão detalhado no plano narrativo quanto os temas dos momentos iniciais do tratamento. Ao longo do plano descritivo, uma série de elementos menores são modificadas com vistas à manipulação psicológica que se tem em vista. Como nos diz Lévi-Strauss:

Quando invadem a morada de Muu, não avançam mais em fila, mas "de quatro em quatro" e, para saírem novamente para o exterior, vão "todos de frente". Essa transformação dos detalhes do mito visa sem dúvida provocar uma reação orgânica correspondente, no entanto, a paciente não poderia incorporá-la na forma de experiência se não viesse acompanhada de um real progresso da dilatação. É a eficácia simbólica que garante a harmonia do paralelismo entre mito e operações. (LÉVISTRAUSS, 1949b, p.216-7). 
A cura, entretanto, ainda não se deu neste momento, é necessário ainda um segundo procedimento, pouco trabalhado nas considerações do antropólogo, na qual o xamã viaja até uma montanha para colher plantas que o auxiliarão a penetrar, ele mesmo, no corpo da doente. A partir deste ponto pode-se considerar a parturiente curada.

Um ponto a ressaltar é o fato de que os termos míticos que designariam os elementos centrais no drama da doença, teriam também uma significação mais imediata, ou seja, o caminho de Muu, no caso a entidade problemática por seus caprichos, designaria literalmente e sem ambiguidades a vagina da parturiente. A utilização destes termos que por sua ambiguidade participariam de dois sistemas de significação, realizariam a função de metáfora para que a sistemática das redes míticas possam se instalar, e assim possibilitar que a palavra mítica, $M v \theta o \varsigma$, possa agir no corpo. É por esta via que o poder de agenciamento mítico poderá tomar o "corpo como o palco onde confluirão eventos paralelos" (LÉVI-STRAUSS, 1949b, p.208) sob a forma de duas cenas desdobradas em planos referenciais e, no caso, epistêmico e ontologicamente distintos, entre o campo do concreto, imediato e o do sobrenatural. Em outros termos, poderíamos dizer que a transformação impressa pela cura xamânica tem como principal condição a articulação entre as estruturas míticas - metafóricas, universais - e as estruturas de tipo sacrificial - metonímicas, produtoras de transmutações ontológicas (Cf. VIVEIROS DE CASTRO, 2002).

$\mathrm{Na}$ economia do escrito, encontra-se entre os argumentos mais importantes o paralelo entre a terapêutica psicanalítica e a praticada pelos xamãs. Tomando as matizes de uma aproximação entre as duas práticas, Lévi-Strauss defende a proposição de que o xamã seria o correlato, nos povos sem-escrita, do psicanalista na sociedade ocidental moderna. Em suas palavras:

A cura xamânica parece ser de fato um exato equivalente da cura psicanalítica, mas com uma inversão de todos os termos. Ambas buscam provocar uma experiência, e ambas conseguem fazê-lo reconstituindo um mito que o paciente deve viver, ou reviver. (LÉVI-STRAUSS, 1949b, p.214) 
Três tópicos despontam na análise do antropólogo como focos de divergência entre os dois procedimentos: o primeiro leva em consideração a natureza do objeto, ou do mal a que se destina a intervenção, sendo, nos termos de Lévi-Strauss, de caráter orgânico no caso do exemplo ali analisado, mas que serviria como diretriz do escopo usual de ação do xamanismo, enquanto que do lado da psicanálise o mal a ser curado seria de caráter eminentemente psíquico. O segundo tópico considera as posições de agenciamento na construção da cena terapêutica como estabelecendo outro fator de distinção, posto que o xamã sustenta uma posição ativa frente ao mito, em torno do qual todas as operações serão realizadas, de vez que é ele quem fala durante o encantamento; enquanto que o psicanalista, por sua vez, é "falado", ou suposto em seus sentimentos e intenções para com o paciente desde o mito que este veicula ao longo do tratamento. Por fim, Lévi-Strauss aponta a natureza do mito como um último fator de diferenciação de ambas as práticas. Em seus termos:

Num caso, é um mito individual que o paciente constrói com elementos tirados de seu passado e, no outro, é um mito social que o paciente recebe do exterior e que não corresponde a um estado pessoal antigo (LÉVI-STRAUSS, 1949b, p.215).

Feitas as distinções, o antropólogo buscará minimizar as diferenças dos dois campos de ação ao evocar para cada ponto assinalado um fato desfaça sua divergência. Estes são respectivamente: (1) o sonho freudiano da possibilidade de estabelecer um correlato bioquímico para suas formulações acerca das psicopatologias individuais; (2) a fala metafórica de Desoille $^{8}$ e a experiência ativa de cura da psicanalista suíça Marguerite Séchehaye ${ }^{9}$ com pacientes diagnosticados como esquizofrênicos; (3) e, a

\footnotetext{
${ }^{8}$ Robert Desoille (1890-1966), foi um médico francês que desenvolveu, na esteira das práticas hipnóticas e sugestivas, uma técnica de psicoterapia chamada de "método do sonho acordado dirigido" e que deu origem a um movimento, o Groupe International du Rêve Éveillé Dirigé de Desoille [Grupo Internacional do Sonho Acordado Dirigido de Desoille] (GIREDD) (ROUDINESCO; PLON, 1997, 626). Esta técnica consistia em intervir na fala do paciente através da sugestão de metáforas. Em $O$ Sonho Desperto em Psicoterapia (1945), Desoille relata que, diante de um paciente que associava sua autoimagem à sensação de estar preso em uma sala sem portas, o médico sugere que use uma escada, e então conclui: "Se constata que a sugestão aceita da 'escada' é um meio simbólico que ajuda o sujeito a liberar-se e rechaçar a imagem negative que tem de si. Recomendaria, encarecidamente, utilizar a imagem como símbolo para o trabalho de deslocamento da energia afetiva (da libido) que é a base da cura psicanalítica" (DESOILLE, 1945, p.14)

${ }^{9}$ Marguerite Séchehaye (1887-1964) foi uma psicóloga suíça responsável por desenvolver e descrever uma técnica de tratamento da esquizofrenia. A partir das influências da psicologia de Piaget, da psicanálise de Freud (e seus sucessores anglo-saxões) e da linguística de Saussure - lembrando que fora casada com Albert Séchehaye, discípulo de Saussure e um dos responsáveis pelo estabelecimento do Curso de Linguística Geral - Séchehaye descreveu em A realização simbólica (1947) e em Diário de
} 
prevalência e eficácia da estrutura do mito na superação do conteúdo ou da fonte da qual ele se serve para construir suas narrativas, não sendo essencial diferenciar se essas são individuais ou coletivas.

Para além das diferenças e suas dissoluções, ilusórias ou não, resta o fato último da unidade das duas estratégias de cura, nas quais encontraríamos, por sua vez, a atualização de uma série mítica a partir de um conjunto de ritos, duas vertentes da ação colocadas em contato pela eficácia simbólica, que propiciariam, seja ao neurótico, seja à parturiente, "uma experiência organizadora de seus estados, conflitos informulados" (LÉVI-STRAUSS, 1949b, p.214), estes causa de suas respectivas patologias. Na comparação entre o tratamento analítico e o xamânico tal como esboçado n'A eficácia simbólica, o eixo organizador se dá através do papel do mito, em sua complexa relação com o rito, nas curas próprias de cada prática.

Tratemos doravante de especificar as duas séries aqui apresentadas, ritual e mítica, em prol da compreensão do uso da categoria de mito nesse momento inicial da empreitada lévi-straussiana, assim como as consequências de sua articulação em um ritual de cura para a consideração futura de sua leitura estrutural.

\subsection{O mito n'A eficácia simbólica: função e associação com o rito.}

Não deixa de causar estranheza a qualquer um que tome a obra de Lévi-Strauss em seu conjunto, o fato de aqui evocarmos o papel do mito predominantemente pelo viés de sua função. Esta dado, por um lado, seria correlato da noção morfológica de estrutura apresentada em As Estruturas Elementares do Parentesco, tal qual criticado por autores como Boon \& Schneider (1974), noção que faz com que a ideia de estrutura parental oscile entre sua função social e sua disposição a constituir significações.

uma Esquizofrênica (1950) uma terapêutica pautada em ações simbólicas que permitiriam à paciente experienciar seus estados regressivos, fundamentais para as "mudanças de sua vida afetiva, responsáveis por sua cura" (SÉCHEHAYE, 1950, p.24). Nos termos de Lévi-Strauss: "Assim, para resolver um complexo de desmame, a psicanalista tem de assumir uma posição materna, não realizada por uma reprodução literal do comportamento correspondente, mas, por assim dizer, com golpes de atos descontínuos, cada um deles simbolizando um elemento fundamental dessa situação, como, por exemplo, colocar o rosto da paciente em contato com o seio da psicanalista. A carga simbólica de tais atos os torna aptos a constituir uma linguagem. Na verdade, o médico dialoga com o paciente, não por meio da palavra, mas por operações concretas, verdadeiros ritos, que atravessam a barreira da consciência sem encontrar obstáculos, para levar sua mensagem diretamente ao inconsciente" (LÉVI-STRAUSS, 1949, p.216). 
Entretanto, por outro, tal ênfase revela a particularidade da associação do conceito de mito a um procedimento ritual de fim terapêutico. Para além da análise das especificidades das transformações estruturais das narrativas míticas, o antropólogo aqui traça seu papel central na reorganização da rede de sentidos que determinam a vivência do doente. O mito atua e é atuado como um dispositor de lugares que, a partir da própria eficácia do símbolo, transpõe para um "mundo outro" os personagens deste mundo - em princípio o doente e o xamã - e, através da superposição de duas cenas, permite ao xamã agir entre as forças e entidades do plano sobrenatural que exercem influência sobre o "espírito do paciente" e, consequentemente, sobre o corpo adoecido. Nas palavras do antropólogo:

O xamã fornece à sua paciente uma linguagem na qual podem ser imediatamente expressos estados não formulados, e de outro modo informuláveis. E é a passagem para essa expressão verbal (que ao mesmo tempo permite viver de forma ordenada e inteligível uma experiência atual, mas que sem isso seria anárquica e indizível) que provoca o desbloqueio do processo fisiológico, i.e., a reorganização, num sentido favorável, da sequência de cujo desenrolar a paciente é vítima (LÉVI-STRAUSS, 1949b, p.213)

A vertente simbólica - como metaforização que produz narrativas desdobradas em duas ou mais cenas inicialmente disjuntas, sempre renovada posto que é da ordem da fala - e a vertente imaginária do mito - como narrativa absoluta, cuja crença na versão atual, sempre atual, a faz de ordem quase sígnica - encontram-se no texto da eficácia simbólica, praticamente inseparáveis. No interior de todo o aparato ritual da cura, composto de danças, música, entonações melódicas de canto, etc., o recitar xamânico é visto por Lévi-Strauss como a serviço do conteúdo simbólico do mito, de vez que é ao receber uma versão ordenada de seus conflitos, originalmente caóticos, a parturiente pode "tornar pensável uma situação dada inicialmente em termos afetivos" (Ibidem, p.212) e, por esta via, ter uma experiência transformadora em seu próprio corpo.

Em outro local (DOMICIANO, 2013), trabalhei potenciais releituras dessa chave de interpretação lévi-straussiana do tratamento xamânico, e em especial, suas 
possíveis consequências para a comparação com a atividade do psicanalista, a partir um fato essencial para a retomada dessa temática, a saber, a questão da língua e do corpo do xamã. A consideração pela dimensão da determinação e do sentido na função do mito, levou Lévi-Strauss, exímio etnógrafo, a omitir um dado que dificilmente poderia ser considerado secundário, a saber: o fato de que o mito kuna em questão seria recitado numa língua sagrada (PERRIN, 1995), portanto, não acessível teoricamente à grande maioria dos doentes que se colocam aos cuidados do xamã. Entretanto, tais fatores, se tocam em outra dimensão do tratamento, não invalidam a interpretação da determinação significante e sua articulação com o reconhecimento de seu drama individual em uma mitologia coletiva.

Antes de tomar a empreitada de Lévi-Strauss até chegar à fórmula canônica do mito e sua reverberação na obra de Lacan, e, dado que tanto no tratamento xamânico, quanto no psicanalítico, há a produção de narrativas míticas integradas a uma ritualística, vejamos como definição operativa da categoria de rito, em especial, no contexto terapêutico, pode nos auxiliar a compreender as particularidades da estrutura mítica posteriormente objeto privilegiado da obra lévi-straussiana.

\subsection{O rito e sua lógica transformativa}

Uma das primeiras imagens dadas por Lévi-Strauss para o entendimento deste fenômeno provém de uma comparação do rito com a noção de jogo (LÉVI-STRAUSS, 1962). Um jogo, qualquer que seja, procede pela instituição de um conjunto de regras pouco numerosas que propiciariam a existência de um número infinito de partidas. $\mathrm{O}$ rito, por outro lado, funcionaria como uma partida especial, privilegiada. Tais características incidem, por sua vez, sobre a função lógica destes dispositivos: se o jogo carrega uma sistematicidade disjuntiva, ou seja, na contínua criação de uma divisão diferencial entre jogadores previamente não distintos (vencedores ou perdedores); o rito, em seu contexto, teria uma função conjuntiva, posto que opera pela união de grupos não só dissociados como assimétricos desde o começo, ou seja, o plano dos vivos e dos mortos, dos que tem uma existência conspícua e dos que existem no mundo invisível, no limite, dos humanos e não-humanos. 
Um rito diria respeito, portanto, a um conjunto de práticas simbólicas discursivas e gestuais altamente padronizadas com vistas a estabelecer um vínculo metonímico, contíguo entre as esferas separadas do mundo "comum" e de um mundo outro, sobrenatural. Esta transposição de fronteiras tem como corolário, por parte daqueles envolvidos na condução ritual, mais que a crença em uma ação prática dotada de rendimento - ou seja, uma ação cujo valor está no resultado de sua ação como alteração do mundo físico - a possibilidade de ordenar, de inscrever alterações nas estruturas sociais construídas, por sua retórica, em um tempo originário, mítico. Em outras palavras:

A operação mágica ou ritual lhe parece uma adição à ordem objetiva do universo: para aquele que a realiza, ela apresenta a mesma necessidade que o encadeamento das causas naturais, onde, sob a forma de ritos, o agente crê inserir apenas elos suplementares. Imagina-se, portanto, que ele observa de fora e como se ela não emanasse dele. (LÉVI-STRAUSS, 1962, p.247)

Essa diferenciação com o pensamento tradicional acerca da crença primitiva de sua potência transformadora, ou onipotência actante, permite retificar tal presunção, posto que a magia repousa inteiramente na crença segundo a qual o homem pode intervir no determinismo natural, completando-o ou modificando seu curso, não importa absolutamente que ele o faça um pouco mais ou um pouco menos: a fraude é consubstancial à magia e, propriamente falando, feiticeiro nunca "trapaceia" (Ibidem).

O domínio do rito marca ainda uma propriedade fundamental do pensamento selvagem, qual seja: ele permite estabelecer uma conjunção não conflituosa entre as esferas conjuntivas e disjuntivas do passado, em outras palavras, o rito estabelece uma dupla via de acesso ao tempo presente, por um lado, da faceta do passado cujos agentes eram de uma natureza distinta dos próprios homens contemporâneos, através da ligação entre vivos e mortos, e, por outro, o rito liga o presente ao passado que não cessa de se reapresentar enquanto fatos sem particularidade, que se inscrevem em uma recorrência cíclica de não-fatos, através da periodicidade biológica ou sazonal.

A lógica do rito, desse modo, segue em diversos contextos, como o terapêutico descrito em $A$ eficácia simbólica, a mesma sistematicidade da esfera do sacrifício que, 
como vimos, é considerada pelo antropólogo brasileiro Viveiros de Castro como deixada de lado nas análises lévi-straussianas. A distinção metodológica entre sacrifício e totemismo é-nos apresentada por Lévi-Strauss nos seguintes termos:

O totemismo repousa em uma homologia postulada entre duas séries paralelas - a das espécies naturais e a dos grupos sociais - das quais, não o esqueçamos, os termos respectivos não se assemelham dois a dois; somente a relação global entre as séries é homomórfica: correlação formal entre dois sistemas de diferenças dos quais cada um constitui um pólo de oposição. No sacrifício, a série (contínua e não mais descontínua, orientada e não mais reversível) das espécies naturais desempenha o papel de intermediário entre dois termos polares, dos quais um é o sacrificador e o outro a divindade e entre os quais, no início, não existe homologia nem sequer uma relação de qualquer tipo; o objetivo do sacrifício é precisamente instaurar uma relação, que não é de semelhança mas de contiguidade, por meio de uma série de identificações sucessivas que podem se fazer nos dois sentidos, conforme o sacrifício seja expiatório ou represente um rito de comunhão: seja, pois, do sacrificante ao sacrificador, do sacrificador à vítima, da vítima consagrada à divindade ou na ordem inversa. (LÉVI-STRAUSS, 1962, p.250)

O antropólogo brasileiro Eduardo Viveiros de Castro vê nessa oposição a representação dos limites de análise da vertente estruturalista da antropologia. LéviStrauss estaria, neste momento de sua obra, circunscrevendo mais uma vez a área na qual pretende e considera possível que seu método se inscreva. Como veremos à frente, uma das frentes comuns aos expoentes da antropologia pós-lévi-straussiana foi se enveredar por este ponto pouco explorado pelo pai do estruturalismo. O modelo do sacrifício postula, portanto, à diferença do totemismo, uma

só série contínua e orientada ao longo da qual se efetua uma mediação real e irreversível entre dois termos polares e não-homólogos, cuja contigüidade deve ser estabelecida por 
identificações ou aproximações analógicas sucessivas (VIVEIROS DE CASTRO, 2008, p.88)

Viveiros de Castro salienta que a oposição entre a sistematicidade do rito, ou do sacrifício, e do totemismo, ou do mito, antes de ser uma forma de oposição significante, é uma diferença não assimilável no mesmo plano de inteligibilidade. Tal distinção se daria pelo fato de o totemismo se constituir como um sistema classificatório preexistente a toda subjetividade, enquanto que o sacrifício e seus sistemas de transformação agiriam diretamente na modificação dos elementos que estão em jogo em seus procedimentos. À epistemologia kantiana a que se entregam as análises estruturalistas, se interpõe a multiplicidade ontológica da racionalidade dos povos selvagens, em especial, no caso da Escola do Rio, dos ameríndios.

\subsection{O legado da primeira incursão sobre a temática do mito}

Como vimos até aqui, a antropologia lévi-straussiana, em seus primeiros desenvolvimentos sobre o mito, empreende uma análise que prioriza a articulação dessa noção a partir de sua função e eficácia na experiência cotidiana do homem. A demonstração do símbolo como um determinante estrutural do homem em todas suas esferas de expressão, individuais e sociais, marcam a grande contribuição do pensamento estrutural neste momento. A psicanálise nesta via é convocada a contribuir a partir essencialmente de sua prática de tratamento.

Ao equacionar a prática psicanalítica à prática xamânica, Lévi-Strauss a enaltece e posiciona como responsável por recuperar uma dimensão da experiência da patologia presente em nossa sociedade e especialmente evidente nas práticas xamânicas, há muito relegadas às mais baixas considerações pela comunidade científica. Em suas palavras:

A despeito das contribuições da psicanálise, há algumas pessoas que, mais impressionadas sem dúvida pelo mal uso da psicanálise que por seu verdadeiro ensino, persistem em considerar essa disciplina como uma extravagância do homem moderno. Em ambos os casos, se esquece que a psicanálise não fez mais que voltar a encontrar e traduzir em termos novos uma 
concepção das enfermidades mentais que remonta provavelmente às origens da humanidade e que os povos que chamamos primitivos não cessaram de utilizar com uma arte que surpreende com frequência nossos melhores praticantes. (LÉVISTRAUSS, 1956, p.8)

A leitura lévi-straussiana da aproximação das duas práticas, além de propiciar uma possível via de formalização da experiência clínica a partir de seus condicionantes simbólicos, como Lacan empreenderá na década de 50, inscreve a lógica mítica no seio do tratamento analítico. A leitura do mito, ainda está, como vimos, intimamente ligada à sua articulação com o ritual e consequente capacidade de dotar de meios a reconfiguração das coordenadas simbólicas que traçam e determinam certa vivência, patológica ou não.

A articulação da lógica mítica com a noção de transferência, tal qual vimos com Freud, é operada pelo próprio antropólogo em $A$ eficácia simbólica. Há aí a tentativa de demonstrar como ao longo de uma análise, um mito é reatualizado, ou melhor, uma versão da constelação psíquica do paciente reaparece na relação com o analista. Tal leitura, recoloca e influi no próprio cerne do entendimento da patologia, em suas palavras:

Convém nos perguntarmos se o valor terapêutico da cura decorre do caráter real das situações rememoradas, ou se o poder traumatizante dessas situações proviria do fato de que, no momento em que elas se apresentam, o sujeito as experimenta imediatamente na forma de um mito vivido. [...] o poder traumatizante resultaria da capacidade de certos eventos, surgidos, num contexto psicológico, histórico e social apropriado, de induzir uma cristalização afetiva que se realiza no molde de uma estrutura preexistente. (LÉVI-STRAUSS, 1949b, p.218)

As experiências dos sujeitos, por esta via, neuróticos, primitivos ou civilizados, seriam assim todas organizadas através de uma estrutura predominante, sob a ação catalizadora do mito inicial. A esta leitura estrutural, Lévi-Strauss interpõe a 
interessante concepção de que independente de se fundar ou não em acontecimentos reais, a propriedade definidora do mito estaria na sua "capacidade de conferir significação ao presente, e não na fidelidade com que reconstituem uma situação inicial” (LÉVI-STRAUSS, 1956, p.10). A perspectiva lévi-straussiana, portanto, reposiciona a dimensão da história para o interior de uma teoria estrutural, na qual, os eventos do passado, possuem seu valor e sentido regulados por um sistema de significação em que a posição diferencial dos elementos define a particularidade de cada um.

O mito, por esta via, se encontraria no cerne do projeto lévi-straussiano de explicitação da lógica simbólica inerente aos fatos humanos. Ao colocar o mito como um modo de expressão dotado de uma eficácia simbólica - pré-subjetiva, capaz de articular um sistema referencial com a dimensão da experiência subjetiva - Lévi-Strauss aproxima-se da posição de Freud quando do reconhecimento do papel constitutivo da narrativa edípica. Vimos como esse passo foi fundamental para a psicanálise freudiana estabelecer um princípio de leitura clínico capaz de extrair do dado particular, uma lógica de necessidade universal. Ora, encontramos o mesmo na antropologia lévistraussiana, haja vista que a categoria mítica surge como um tipo específico de fenômeno capaz de, para além de sua configuração imediata, inscrever uma lógica universal, estrutural sobre os dramas particulares.

Se a explicitação do fato de essas narrativas míticas influenciam estruturalmente as vivências em geral e se apresentam especialmente presentes na experiência dos tratamentos pautados na palavra, cantada ou falada, falta ainda neste momento na obra lévi-straussiana uma análise dos condicionantes estruturais de tais fenômenos. O modelo de análise da articulação entre mito e rito dará lugar, como veremos, à pura sistematização dos determinantes significantes da formação de um mito, ou do conjunto de narrativas míticas. Este passo marca uma importante contribuição para a formalização desse fenômeno, em especial, para a teoria lacaniana da linguagem e da constituição do sujeito.

A possibilidade de articulação entre esse viés de tratamento do mito, através de sua função e eficácia, tal como ligada à noção de transferência, com a faceta de interpretação dos meandros de sua estrutura, assim como presente na leitura freudiana 
estará presente em Lacan, e nos possibilitará reinterpretar a matriz da fórmula canônica do mito, como um modelo importante na teorização lacaniana da clinica analítica.

Como veremos, A eficácia simbólica marcou para a psicanálise, em especial à obra de Lacan, o retorno à possibilidade de entrever o simbólico em toda sua potência de determinação da subjetividade e de nortear experiência psicanalítica, tal qual descoberta por Freud. Segundo Zafiropoulos, há uma "teoria da interpretação que Lacan endossa de Lévi-Strauss, pelo o que nela concerne a neurose, seu mito e sua cura" (ZAFIROPOULOS, 2004, p.26). Poderíamos aqui, de forma mais esquemática, sintetizar suas grandes contribuições ao projeto lacaniano de releitura das bases da experiência analítica nas seguintes teses:

(1) Encontramos aí, uma teoria da cura, que enfatiza o papel central do simbólico em sua eficácia de determinação da vivência corporal e subjetiva dos sujeitos; A tese auxiliar de que o xamã operaria no interior do tratamento de forma homóloga ao psicanalista;

(2) A noção de mito apresentada como possuindo uma lógica temporal própria para operar na reestruturação da experiência do paciente, ponto em comum à prática de cura xamânica e psicanalítica. Em outros termos, a capacidade de articulação do mito em uma lógica ritual, seria responsável por sua inscrição na experiência "intensamente vivida" própria da cura;

(3) O sintagma "mito individual" é apresentado como caracterizando o modo de organização subjetiva particular do neurótico. Por esta argumentação o neurótico sofre pela impossibilidade de fazer de sua narrativa individual se integrar à esfera de reconhecimento do coletivo. O diagnóstico social aí implicado, permite a consideração do mito individual por uma chave histórica-antropológica. Se a neurose se organiza em torno de uma estrutura mítica, torna-se possível a releitura do conceito de transferência, em sua acepção simbólica, como um dispositivo de arranjo e atualização das versões de um "mito individual";

(4) Uma teoria do papel do simbólico na construção da realidade psíquica, com seus efeitos para a formalização do que seriam, posteriormente, a teoria das estruturas clínicas. Lévi-Strauss, ao retraçar a questão da capacidade traumatizante de certas 
experiências da criança, ou melhor, de potencialmente induzirem a uma fixação libidinal, revê o seu pretenso estatuto de realidade vivida em prol de uma consideração pelos agenciamentos simbólicos que determinaram esta mesma vivência, em outros termos, de que "os eventos, surgidos num contexto psicológico, histórico e social apropriado, são capazes de induzir uma cristalização afetiva realizada nos moldes de uma estrutura preexistente" (LÉVI-STRAUSS, 1949b, p.218). Lacan retomará tal revisão, por exemplo, em Função e campo da fala e da linguagem (1953b) ao afirmar que os pretensos estágios de desenvolvimento libidinal são eles mesmos históricos em sua essência (LACAN, 1953b, p.262);

(5) Por fim, encontra-se aí uma teoria da noção de inconsciente enquanto estruturado como uma linguagem, ou seja, um conjunto de leis, uma gramática que sistematiza conteúdos compostos de materiais quaisquer; Sobre a natureza eminentemente simbólica do inconsciente, encontramos as seguintes palavras de LéviStrauss:

Em relação ao evento ou à anedota, essas estruturas ou, mais exatamente, essas leis de estrutura - são realmente atemporais [...] $\mathrm{O}$ conjunto dessas estruturas formaria o que chamamos de inconsciente. [...] o inconsciente deixa de ser o inefável refúgio das particularidades individuais, o repositório de uma história única, que faz cada um de nós ser insubstituível. Reduz-se a um termo com o qual designamos uma função, a função simbólica, especificamente humana sem dúvida, mas que em todos $\mathrm{s}$ homens se exerce segundo as mesmas leis. [...] o inconsciente é sempre vazio [...] e limita-se a impor leis estruturais, que lhe esgotam a realidade, a elementos esparsos que lhe vem de fora. (LÉVI-STRAUSS, 1949b, p.219)

Se essas teses serão centrais para a empreitada lacaniana, eles não serão levadas às últimas consequências até a conferência que marcou o início de uma referência estruturalista como forma (LACAN, 1966, p.76), a saber, $O$ mito individual do neurótico, de 1953. Para acompanhar o valor da lógica formal do significante ao projeto lacaniano, introduzida pelo estudo do mito, vejamos como se deu o percurso de 
Lévi-Strauss na construção do modelo da fórmula canônica do mito, assim como seus passos para a passagem da análise do parentesco à análise dos mitos.

\section{O périplo estrutural de Lévi-Strauss: dos modelos de formalização do parentesco ao mito}

A vereda pelos mitos, ou por sua análise estrutural, tal qual realizada por LéviStrauss, reconhecidamente a mais extensa de sua obra, deu-se poucos anos depois da conclusão de As Estruturas Elementares do Parentesco. Feita a incursão pelas regras de casamentos e sistemas de parentesco, o antropólogo foi gradualmente fixando suas reflexões no campo do pensamento mítico. Como encontraremos insistentemente presente nas palavras do antropólogo, a passagem de um campo das manifestações culturais para outro não teria se dado, como pode parecer à primeira vista, por meio de uma ruptura, mas sim por uma contiguidade, onde o segundo passo seria uma extensão e um aprofundamento do primeiro. Em suas palavras:

Trata-se sempre de, partindo da experiência etnográfica, fazer um inventário dos imperativos mentais, reduzir dados aparentemente arbitrários a uma ordem, atingir um nível onde uma necessidade, imanente às ilusões de liberdade se revela. Destacamos, n'As Estruturas, um pequeno número de princípios simples, cuja intervenção fazia com que um conjunto muito complexo de usos e costumes, à primeira vista absurdos, fosse redutível a um sistema significativo. Nada garantia, entretanto, que tais imperativos fossem de origem interna. [...] Portanto, a experiência que iniciamos agora com a mitologia será mais decisiva. (LÉVI-STRAUSS, 1964, p.29)

Desta guisa, entramos em contato na Abertura de O Cru e o Cozido, primeira obra das quatro que formam a série das Mitológicas, com o antropólogo advogando pelo grande avanço dado na busca destes "imperativos". O fundamento desta citação se dá no argumento defendido por Lévi-Strauss de que a mitologia seria uma atividade que, diferente de todas as que ele analisara até então, não possuía uma finalidade, uma função prática evidente, portanto, aqui, aparentemente teria o espírito "total liberdade 
para se entregar à própria criatividade espontânea" (Ibidem). A esta premissa ele interpõe a ideia constitutiva do pensamento estrutural de que "se há leis em alguma parte, deve havê-las por toda parte", recolhida de Tylor e que servira de epígrafe para $A s$ Estruturas Elementares (LÉVI-STRAUSS, 1949a; 1964). Por estas razões ele conclui: "se o espírito humano se mostra determinado até mesmo em seus mitos, então a fortiori deve sê-lo em toda parte".

Nesta apresentação, ele caracteriza sua busca por imperativos mentais como análoga a um "kantismo sem sujeito transcendental” (LÉVI-STRAUSS, 1964, p.30), valendo-se assim da expressão cunhada por Paul Ricoeur, e a mitologia seria então a via régia para a objetivação deste tipo de pensamento independente de qualquer sujeito consciente. No entanto, acerca de sua chegada à análise dos fenômenos míticos, por mais que não coloquemos em questão a identidade da problemática e do método que, tanto no campo dos fatos sociológicos quanto no dos religiosos, consiste em "descobrir uma ordem subjacente, uma estrutura profunda através de cujo efeito possamos analisar essa diversidade aparente, em uma palavra, vencer a incoerência." (LÉVI-STRAUSS, 1988, p. 181), não podemos deixar de assinalar uma questão que responde, em certa medida, se não pelos futuros desdobramentos dessa empreitada, pelo menos por uma parte de seu primeiro passo: esta, como apontamos, de ordem contingencial, diz respeito à eleição de Lévi-Strauss, no final da década de 40, à cátedra dedicada aos fenômenos religiosos na École Pratique des Hautes Études. Como nos diz o antropólogo, que até então se tinha ocupado principalmente com regras do casamento e sistemas de parentesco: "De um dia para o outro, tive que mudar meu objetivo." (Ibidem, p.95)

As Estruturas Elementares, entretanto, marcam um momento de sua obra em que seu posicionamento frente ao fenômeno de campo, antes de privilegiar a operação de explicitação dos determinantes estruturais de cada fenômeno particular, como o mito, a totemismo, etc., refletia a necessidade de se afirmar a grande descoberta da demonstração através do método linguístico da estruturalidade dos fenômenos sociais. Como diversos comentadores salientam, há nesta obra, que bem pode ser caracterizada como "pré-estrutural”, um modelo morfológico de estrutura (VIVEIROS DE CASTRO, 1996). Opera-se aí através da redução da diversidade (BOON \& SCHNEIDER, 1974) dos fenômenos em prol de oposições extraídas de termos "fixos e presumivelmente universais" (GOLDMAN, 2005, p.73). Os termos da lógica combinatória são privilegiados à própria ideia de relação entre estes (STOCKLER, 2005, p.284). A 
despeito de suas implicações teórico-metodológicas, para os objetivos ora propostos, apenas atentaremos para a estaticidade do modelo utilizado, que logo cederia lugar para uma análise "francamente estrutural" (Ibidem, p.285).

A partir do postulado presente em A eficácia simbólica de que, por meio da "lógica ambígua própria da produção mítica" (VERNANT, 2002, p.21) a integração de elementos contraditórios teria per si uma eficácia terapêutica, o Lévi-Strauss permitirá, como já dissemos, a Lacan notar a importância e o potencial de formalização deste registro essencial para a experiência analítica que é o simbólico. Como analisamos, o escrito lévi-straussiano, traz a noção de estrutura intimamente relacionada à tendência na qual os fenômenos realizam e transmutam, antecipando a leitura da estrutura como a de transformações coordenadas de um conjunto de variantes.

Logo após a publicação deste artigo, encontramos uma importante inflexão da posição lévi-straussiana em seu projeto de formalização e de consideração das possibilidades do campo simbólico. A precedência e excelência do simbólico começam aqui a tomar contornos mais delimitados, chegando a ser teoricamente formalizado no consagrado artigo Introdução à obra de Marcel Mauss, de 1950. Neste escrito, marcado em seu cerne pelo excesso, Lévi-Strauss subverte a própria noção de introdutio, e realiza aí uma cartilha de seu programa futuro ${ }^{10}$ ao lançar mão de diversas ideias que guiarão doravante suas reflexões, como, por exemplo, a função do significante precedendo e determinando o significado, a necessidade de uma matematização dos fenômenos míticos, e, principalmente, articulada às anteriores, a noção de um significante flutuante, de "valor simbólico zero, garante de toda arte, toda poesia, toda invenção mítica e estética” (LÉVI-STRAUSS, 1950, p. 43), a saber, no caso, o mana.

${ }^{10}$ Introdução à obra de Marcel Mauss fora encomendado a Lévi-Strauss por Georges Gurvitch para abrir à coletânea póstuma de Marcel Mauss Sociologia e Antropologia. Lévi-Strauss, além de ser o sucessor da cátedra de Mauss na EPHE, gozava de grande prestígio à época em razão da recente publicação de As Estruturas Elementares. Entretanto, Gurvitch, diretor da coletânea, mostrou-se insatisfeito com o texto apresentado por Lévi-Strauss, como este nos conta: "Visivelmente, [Gurvitch] não tinha gostado do meu texto. Depois de tê-lo lido, acrescentou nas provas um curto pós-escrito, através do qual percebia-se sua desaprovação. Foi aí que as coisas começaram a se deteriorar" (LÉVI-STRAUSS, 1988 , p.95). A difícil relação que se iniciou entre os pensadores, tornou-se pública através de artigos críticos e acusatórios surgidos ao longo da década de 1950. 
Ao desvencilhar-se da representação maussiana de mana enquanto cópula ${ }^{11}$, Lévi-Strauss permite a conceitualização de um significante equivalente a uma "função semântica cujo papel é permitir ao pensamento simbólico exercer-se apesar da contradição que lhe é própria" (Ibidem). Em outras palavras, mana seria um tipo de significante especial que teria sua significação, sua determinação gramatical, a princípio suspensa, posto que comporta em si a possibilidade de diversas significações. No entanto, tal qual um dêitico, poderia fixar certo grau de determinação de seu significado no momento de sua enunciação. O valor dialético deste conceito dá mostras de como Lévi-Strauss inscreverá em sua noção de estrutura a dimensão da história. Evento e estrutura se encontram nesta formulação. Dois importantes pontos decorrem daqui.

Ao marcar a primazia da função simbólica sobre fenômenos de diversas outras ordens, forjando um sistema de interpretação que explica de maneira simultânea os aspectos físicos, físiológicos, psíquicos e sociológicos de todas as condutas (Cf. LÉVISTRAUSS, 1950), Lévi-Strauss realiza, segundo Zafiropoulos (2006), a inauguração de uma "nova antropologia". Esta, ao tratar como linguagem a realidade social, permite àquele que sobre elas debruçar suas análises, extrair de um dado campo de fenômenos uma estrutura da mesma magnitude que de um campo distinto. Como trataremos à frente, isso exigirá uma reformulação da noção de estrutura, contribuirá para a extensão dos resultados das análises do parentesco para a análise mítica.

O segundo ponto a salientar é o de que, ao formalizar um símbolo que apenas teria a função de assinalar a errática hiância existente entre a superabundância do significante e o significado, Lévi-Strauss abre a própria noção de estrutura à diacronia, ressaltando, deve-se notar, o conceito de transformação. Este ponto será central quando da análise da fórmula canônica pela qual Lévi-Strauss formaliza o mito, no entanto, vale aqui destacar que não é sem consequências esta prevalência retórica (VIVEIROS DE CASTRO, 2008) que a noção de transformação progressivamente conquista em relação ao conceito de estrutura, a ponto mesmo de ser considerado, em 52, como condição sine qua non para a determinação de um conjunto sistêmico. Tal modificação marcará tanto uma revisão de algumas análises do parentesco (LÉVI-STRAUSS, 1952), como a

${ }^{11}$ A noção de mana enquanto cópula entre dois elementos isolados é rechaçada por LéviStrauss, posto que esta apenas tornaria patente a equivalência simbólica num outro plano destes mesmos dois termos 
postulação de um possível metamodelo que abrangeria mais de uma categoria de fenômenos, através da noção de pensamento selvagem (LÉVI-STRAUSS, 1962).

Como atestam as atas de seus cursos na EPHE, os anos letivos de 1952-53 e 1953-54, foram os primeiros dedicados às pesquisas de mitologia, em especial, a americana, onde se deu início a um "estudo comparativo das diferentes versões conhecidas do mito de emergência entre os índios pueblo ocidentais e centrais (hopi, zuni e acoma). Foram aí analisados e comentados cerca de 30 versões com a esperança de delas extrair alguns princípios gerais" (LÉVI-STRAUSS, 1952-53, p.243). A partir dessa empreitada inaugural, teremos na obra lévi-straussiana a realização de uma primeira formalização do funcionamento sistêmico dos mitos, concretizada no escrito $A$ estrutura dos mitos, de 1955, texto seminal para a introdução da concepção de mito em Jacques Lacan e para a inscrição, ou antes, a assimilação do pensamento de LéviStrauss em sua teorização. Tomemos tal incursão inicial do antropólogo até a inscrição daquela que se tornou uma matriz em seu estudo sobre os mitos, mas que nem por isso deixou de ser incompreensível aos seus pares e relegada por décadas ao ostracismo (MARANDA, 2001, p.4), a saber, a fórmula canônica do mito.

\subsection{A categoria de mito e os princípios de sua leitura estrutural}

Desde as primeiras linhas de $A$ estrutura dos mitos, Lévi-Strauss retoma o difícil percurso da problemática do mito no interior do pensamento ocidental e da sua disciplina em específico. Por décadas fora das preocupações da etnologia religiosa, tal temática esteve abandonada a toda sorte de interpretações, que apenas contribuíram para a veiculação de preconceitos e ingenuidades sobre seu valor científico e, mesmo, estético. Destas procediam o substrato legitimador de sua posição de exclusão em relação à possibilidade de uma análise racional. Nesta conjuntura, "eles parecem se reduzir todos a um passatempo, um jogo gratuito, ou a uma forma grosseira de especulação filosófica.” (LÉVI-STRAUSS, 1955, p,222), como podemos notar nesta citação do antropólogo Lucien Lévy-Brühl:

Os mitos não tem sobre nós nenhuma ação, posto que são narrativas.... estranhas, para não dizer absurdas e incompreensíveis, até o ponto em que faz-se necessário um 
esforço para que nos interessemos por elas. (LÉVY-BRUHL, 1949 apud LÉVI-STRAUSS, 1960, p.72)

Ao reconhecer o valor daqueles que fundaram a etnologia religiosa, ou seja, Tylor, Fraser e Durkheim, Lévi-Strauss lamenta que esta tenha abandonado o projeto de levar adiante a análise de suas questões pelo crivo de uma psicologia intelectualista. Para se retomar este projeto, argumenta Lévi-Strauss:

"Teria sido preciso alargar os quadros de nossa lógica para incluir operações mentais aparentemente diferentes das nossas, mas que são intelectuais na mesma medida. Em vez disso, tentou-se reduzi-las a sentimentos amorfos e inefáveis". (LÉVI-STRAUSS, 1955, p.221)

Lançado no mundo caótico das interpretações grosseiras, o mito será apreendido por alguns teóricos como a expressão dos sentimentos fundamentais das sociedades em que são veiculados; outros voltarão suas ilações para entendê-lo como uma forma de explicar fenômenos difíceis de se compreender, astronômicos, meteorológicos, etc.; outros ainda, estes os psicanalistas, como os concebe Lévi-Strauss, e alguns etnólogos, simplificam suas interpretações ao aproximarem, para além da medida, os campos inerentes à psicologia e à sociologia fazendo do mito, portanto, a simples imagem refletida no psiquismo da estrutura e das relações da sociedade em que estes se encontram, assim, uma sociedade onde a avó fosse encarada como uma pessoa malévola apresentaria, decerto, um mito da "grande avó má" ou coisa que o valha (Cf. LÉVI-STRAUSS, 1955, p.222-3).

No entanto, a partir do início da década de 50, Lévi-Strauss buscará, a exemplo da psicanálise freudiana, reintroduzir a questão do mito no rol de fenômenos passíveis de uma análise sistemática e racional, tal como já previsto pelo seu projeto de retomada estrutural das análises de temas da pesquisa etnológica que historicamente estiveram entregues à marca do ininteligível, do primitivo.

A categoria de mito, neste contexto, pode ser descrita como uma produção discursiva provinda do fundo dos tempos, de um antes temporalmente heterogêneo (VEYNE, 1983), antes de qualquer contador existente, que trata de acontecimentos e façanhas protagonizados por seres, em alguma medida, sobrenaturais, divinos, que 
“determinaram a existência de uma estrutura presente e permanente" (LÉVI-STRAUSS, 1955, p.224).

Um mito, eis um passo importante na leitura lévi-straussiana, seria uma tentativa, sempre renovada, posto que é da ordem da fala, de responder a um enigma. Uma questão de precário tratamento discursivo, simbólico, se quisermos, constitui o centro articulador de toda narrativa mítica, posto que ela se efetiva no justo momento em que se constitui a hiância entre sua possibilidade de enunciação e sua impossibilidade de resposta unívoca. Em outros termos:

O mito teria como função, evocar um passado abolido, e aplicá-lo, como uma malha, sobre a dimensão do presente, a fim de decifrar um sentido onde coincidam as duas faces: a histórica e a estrutural. (LÉVI-STRAUSS, 1960, p.45)

Diante da impossibilidade inicial de lidar com duas posições contrárias, com um problema aparentemente insolúvel "enquanto esta contradição é real" (LÉVISTRAUSS, 1955, p.248), o pensamento mítico procederia pela tentativa de mediação, pelo infinito desdobramento desta contradição. Lacan, em debate com o antropólogo, relê tal propriedade do mito como operando

através do equacionamento, sob uma forma significante, de uma problemática que tem por si só de deixar necessariamente algo em aberto, respondendo ao insolúvel significando a insolubilidade, fornecendo, assim, (esta seria a função do mito) o significante do impossível. (LACAN, 1956, p.91)

O mito, portanto, teria essa característica fundamental de dar formulação discursiva ao que não pode ser expresso no discurso corrente, dada a falta de recursos para expressar esse vazio. Como vimos no primeiro momento da análise mítica lévistraussiana, sua consideração não estava dissociada de seu papel na eficácia da cura, em sua faceta de integrar elementos anteriormente desconectados, o mito, portanto, encontra-se articulado com um conjunto de operações rituais que trabalham para unir a dupla cena colocada pelo mito, ou seja, para fazer com que a eficácia do símbolo opere em sua máxima potência no real do corpo. Esta é a via pela qual, se nos é permitido 
depurar de A eficácia simbólica o princípio de uma análise estrutural do mito, poderíamos salientar a leitura de que todo e qualquer mito apresenta uma operação de desdobramento, equacionamento de uma problemática inassimilável em outra versão, outra narrativa que busque conferir uma posição de significação a todos os elementos presentes na cena, "um sistema em que tudo se encaixa” (LÉVI-STRAUSS, 1949c, p.213). Tanto, a via do desdobramento, quando da busca de significação global de seus elementos, serão essenciais aos desenvolvimentos das análises de $A$ estrutura dos mitos e de $O$ Pensamento Selvagem, respectivamente.

No escrito que ora tratamos, após situar a posição de sua apropriação da questão do mito no interior da história de sua apreensão - desde o rechaço à possibilidade de uma análise inteligível, até a psicologização de sua narrativa - LéviStrauss o situará como um fenômeno de linguagem e, consequentemente, passível de decomposição estrutural em unidades constitutivas mínimas que formariam seu sistema. Entretanto, uma ressalva se faz presente:

Aproximar o mito da linguagem não resolve nada: o mito faz parte da língua, é pela palavra que o conhecemos, ele pertence ao discurso. [...] Se quisermos dar conta das características específicas do pensamento mítico, devemos, portanto, estabelecer que o mito está ao mesmo tempo na linguagem e além dela. (LÉVI-STRAUSS, 1955, p.224).

Se Lévi-Strauss o coloca como além da linguagem, é justamente para responder a uma questão central no que concerne às interpretações dos fenômenos etnológicos e que Boas, e posteriormente Mauss, já haviam observado com relação aos mitos: como podem haver narrativas que se aproximem tanto em seus detalhes, produzidas por povos tão distantes geográfica e temporalmente? Como vimos, com relação à linguagem, Saussure já havia postulado um recorte entre dois planos distintos, como o da fala, em sua vertente diacrônica e estatística, e a língua, em sua sincronicidade estrutural. Aqui o antropólogo se permite entrever uma terceira dimensão da linguagem presente nos mitos: todas as narrativas míticas se referem a acontecimentos passados, distantes de forma inimaginável no tempo, no entanto, sua grande marca "provém do fato de que os eventos que se supõe ocorrer num momento do tempo também formarem uma estrutura permanente, que se refere simultaneamente ao 
passado, ao presente e ao futuro." (Ibidem, p.224). O mito, por tal característica, resguardaria em sua estrutura uma duplicidade temporal, ao mesmo tempo histórica e ahistórica, que, ainda segundo Lévi-Strauss

“explica que o mito possa simultaneamente pertencer ao âmbito da fala (e ser analisado enquanto tal) e ao da língua (na qual é formulado) e ainda apresentar, num terceiro nível, o mesmo caráter de objeto absoluto. Esse terceiro nível também possui uma natureza linguística, porém se distingue dos outros dois" (LÉVI-STRAUSS, 1955, p.225).

O desafio de se pensar em uma unidade discursiva que "decola da linguagem", leva, então, o antropólogo a se deparar com a difícil investigação de quais seriam as características intrínsecas das unidades mínimas constitutivas de um mito. Diferentemente das unidades encontradas na língua, como os fonemas, morfemas e lexemas, os mitemas, como Lévi-Strauss as denomina, não seriam formados por um sistema de oposição entre elementos, particulares discretos.

Os mitemas, por esta via, à diferença do sistema da língua, seriam grandes unidades constituídas por "feixes de relações", relações entre relações, fragmentos de história, que combinadas entre si as dotariam de sua função significante, e que, ademais, expressariam a característica do mito de decolar dos discursos comuns, ainda presos à ordem da língua. O mito, em oposição direta à poesia, seria reconhecido enquanto tal em qualquer língua em que fosse veiculado, tendo o valor de Traduttore, Traditore reduzido a zero. Em outros termos, segundo Lévi-Strauss, enquanto a poesia poderia ser considerada a expressão linguística de mais alta pregnância à sua língua de origem - o que justificaria a extrema dificuldade de se transpor versos e glosas para diferentes línguas - o mito despontaria no polo oposto, como um tipo de discurso que a um só tempo estaria ligado ao particular da língua em que é veiculado, e ao universal da estrutura que o faz se reconhecido enquanto tal, em qualquer lugar do mundo.

A partir deste ponto, Lévi-Strauss introduz uma concepção de mito até então inédita na história da sua disciplina: a partir de uma operação metodológica, pressuposta pela análise estrutural, o antropólogo recortará o mito, como um todo, da narrativa que é contada. Para o antropólogo, esta narrativa passa a ser considerada uma versão de um mito, pois de agora em diante, o mito será considerado como a totalidade das versões 
produzidas em torno de uma mesma problemática. O esforço do antropólogo que se dedica a estes fenômenos, portanto, não deve ser como o de um historiador a buscar o protótipo da versão primordial de um mito, de onde derivaram todas as outras, ou a versão mais completa da qual todas as demais seriam apenas subtipos imperfeitos, distorcidas ou lacunares (Cf. SCUBLA, 2001, p.124), como pretendia o projeto de Rivers. As palavras do antropólogo francês acerca dos primeiros passos dessa jornada atestam como tal passo é logicamente inicial:

Em primeiro lugar, decidimos tratar todo discurso mítico como uma espécie de metalinguagem, cujas unidades constitutivas seriam temas ou sequências, privados em si mesmos de significação, ao modo dos fenômenos da língua, e que só ganham um sentido através de sua articulação em sistema. (LÉVI-STRAUSS, 1952-53, p.243)

Ao trazer a figura da metalinguagem, Lévi-Strauss não pretendia posicionar o mito como uma modalidade discursiva cujo valor de verdade fosse superior aos demais usos da língua. A referência aqui é justamente à noção de estrutura como um modelo de articulação lógico que seria apreendido das múltiplas transformações, no caso, das versões do mito. Antes considerar a produção de um mito regulado por uma matriz simbólica universal, Lévi-Strauss compreende os mitos definidos, em sua contra-face, por uma questão fundadora em torno do qual as narrativas se articulam.

Realizadas tais distinções, Lévi-Strauss passará à demonstração das particularidades da análise mítica. Assim, fazendo uso do léxico musical, definirá o movimento da narrativa, de uma versão, como o desenrolar diacrônico, melódico, de uma linha de instrumento. Entretanto, como sabemos, uma partitura não é composta apenas por uma linha horizontal, ela representa em uma mesma marcação diacrônica de tempo o conjunto dos instrumentos, que entram ou saem de cena a depender do momento da música. A relação sincrônica entre diferentes instrumentos, marcam sua harmonia e podem ser lidos a partir de uma linha vertical sobre a partitura. Se a imagem final da análise das narrativas parece acessível ao leitor, o antropólogo mostra clareza da dificuldade de se extrair tais unidades do material bruto. Em seus termos:

O mito será manipulado como se fosse uma partitura musical que tivesse sido transcrita por um apreciador perverso, 
uma pauta depois da outra, na forma de uma série melódica contínua, e que tentássemos restituir seu arranjo inicial. Algo como se nos fosse apresentada como uma série de números inteiros, do tipo, 1, 2, 4, 7, 8, 2, 3, 4, 6, 8, 1, 4, 5, 7, 8, 1, 2, 5, 3, $4,5,6,8$ e nos fosse pedido que agrupássemos todos os 1 , todos os 2 , todos os 3 etc.; o resultado é um quadro:

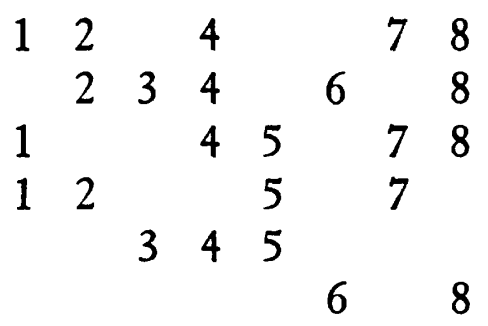

(LÉVI-STRAUSS, 1955, p.229)

A análise estrutural do mito, portanto, ficaria marcada por uma conjugação entre a articulação sincrônica dos diversos instrumentos e a perspectiva diacrônica destas relações (LÉVI-STRAUSS, 1955, p.227-8). Os mitemas, nesta lógica, seriam definidos como grandes unidades formadas a partir de eixos verticais, portanto, relações comuns extraídas de fragmentos narrativos de diferentes versões, que se oporiam, se articulariam, com outros mitemas, diacronicamente distintos. Em outros termos: se fossem ser contados, não seriam levados em conta os eixos verticais, e seriam lidos da esquerda para a direita e de cima para baixo. "Porém, quando se trata de compreender o mito, uma metade da ordem diacrônica (de cima para baixo) perde seu valor funcional e a "leitura" é feita da esquerda para a direita, coluna por coluna, tratando cada coluna como um todo" (Ibidem, p.230). A dimensão da melodia e da harmonia seriam portanto indissociáveis na lógica mítica.

Essa definição do mecanismo de construção e decomposição dos mitos permite a leitura de sua forma como uma estrutura de duas dimensões. A notação bidimensional daí derivada, ao ser considerada globalmente pelo conjunto de mitos, poderia derivar em um grupo de transformações estruturado em três dimensões (Ibidem, p.234). Este seria o início de uma matematização própria do fenômeno mítico, passo primeiro, para sua posterior construção do modelo da fórmula canônica que veremos a seguir. Pelas razões de Lévi-Strauss: 
O mito consiste no conjunto de suas versões; e, como esse conjunto é por definição incompleto (e, como tal aberto), fomos levados a considerar o mito como um conjunto nãocadastrável, que só se pode conhecer por aproximação. Essa estrutura do mito, constituída por camadas ad infinitum, reproduz-se no seio de cada versão, cujos episódios, aparentemente sucessivos, não se alinham segundo uma ordem irreversível ao modo dos eventos históricos: trata-se, antes, de reproduções de um modelo fundamental apresentado sob um numero de perspectivas diferentes igual ao das versões. (LÉVISTRAUSS, 1952-53, p.243).

Ao considerar um mito como um conjunto não cadastrável, essencialmente incompleto, Lévi-Strauss o coloca como um equivalente, no campo do pensamento mítico, do que formalizou anos antes, no campo dos sistemas de parentesco, sob a terminologia de troca generalizada. O conjunto mítico, portanto, se definiria, como nas trocas generalizadas, por uma incessante variação de suas versões. Diferentemente, como vimos, de outras narrativas, que encontram seu fundamento na exata correspondência de sua história original, ou pelos seus detalhes gramaticais mínimos, cujo exemplo extremo é o da poesia, o mito se define pela inexistência de tal modelo, pela falta de uma narrativa unívoca que carregasse consigo seu valor mítico. Eis a abertura que a dupla torção encontrada nos termos finais da fórmula canônica busca expressar. Antes de entrarmos nos termos da fórmula proposta por Lévi-Strauss, vejamos como ele apresenta o procedimento de análise estrutural dos mitos, com o exemplo de um mito bem conhecido pelos psicanalistas, a saber, o mito de Édipo.

\subsection{O mito de Édipo e a primeira aplicação do método estrutural}

Em $A$ estrutura dos mitos, Lévi-Strauss faz a primeira exposição escrita de seu modelo estrutural através da análise do mito de Édipo, mito que, segundo o antropólogo, "tem a vantagem de ser conhecido por todos e que nos dispensa de narrálo" (LÉVI-STRAUSS, 1955, p.228). Sua escolha, entretanto, não deve permanecer indiferente aos psicanalistas, haja vista a expressa menção de seu valor para a teoria psicanalítica, como veremos à frente. 
A ampla difusão da lenda tebana, contribuiu para que este exemplo fosse, entre seus pares e críticos, o mais comentado quando se trata de seu modelo de formalização dos mitos, como também termos oportunidade de observar. Entretanto, como o próprio Lévi-Strauss fez questão de notar, seu valor exemplar apenas seria possível, dada a economia do artigo, através de uma exposição análoga à de um vendedor ambulante. $\mathrm{O}$ "método de camelô", como nomeado por Lévi-Strauss, consiste em uma manobra através da qual "não se trata de obter um resultado, e sim de explicar, o mais brevemente possível, o funcionamento da engenhoca que se quer vender aos transeuntes" (LÉVI-STRAUSS, 1955, p.229).

Diante de tal conjuntura, o antropólogo inicia a leitura do mito de Édipo, tal qual preconizado em suas premissas, a partir de todo o conjunto de narrativas de sua linhagem, de forma a estabelecer os pacotes de relações comuns às diversas narrativas. Nas palavras de Catherine Clément:

A primeira regra do método consiste em coligir todas as versões do mito, sejam quais forem suas origens, traduções, autores, organizadores, etc. Desse modo, o mito de Édipo não começa com o nascimento de uma criança que depois é abandonada pelos pais por causa de uma maldição profética, mas com o fundador da linhagem Labdácidas, o herói Cadmo, irmão de Europa, a bela seduzida por Zeus que se transformara em touro. Igualmente, a história de Édipo não termina com o castigo do culpado incestuoso e parricida que vazou os próprios olhos, mas com a morte de Antígona, condenada por ter sepultado um dos seus irmãos desobedecendo a um decreto do rei Creonte. (CLÉMENT, 2002, p.43)

A extração dos mitemas, como nos lembra o antropólogo Mauro Barbosa de Almeida, explicitará séries de relações comuns que procedem da atribuição de um sujeito a um predicado, no qual este é um comportamento transitivo, por que supõe um ator e um objeto de ação (ALMEIDA, 2008, p.152). Portanto, cada mitema, nos termos da fórmula canônica, que veremos à frente, denotará um tipo de predicado específico e os termos a ele associado, ou seja, cada unidade representará em seu conjunto os 
elementos aos quais tais predicados serão atribuídos. O resultado de sua análise é um quadro do seguinte tipo:

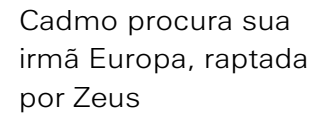

Édipo mata seu pai, Laio

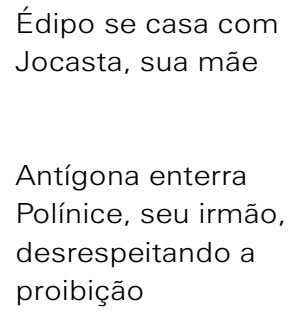

Etéocles mata seu irmão, Polínice

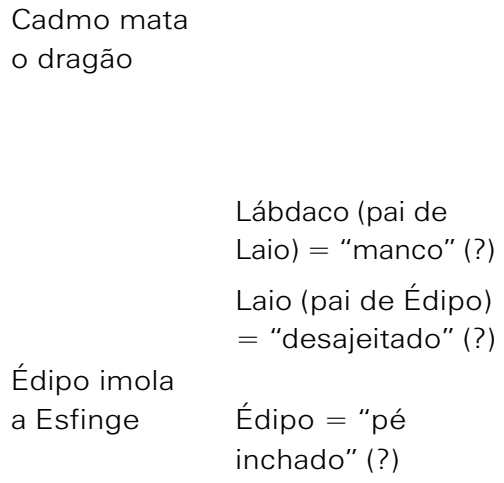

Vejamos cada um dos seus termos. Lévi-Strauss apresenta a primeira série paradigmática - expressa por "Cadmo procura sua irmã Europa”, “Édipo se casa com Jocasta", "Antígona enterra Polinice" - como agrupada, no conjunto do mito tebano, pela traço comum de representarem relações entre parentes próximos dotadas de um excesso, um exagero, ou nos termos do antropólogo, como "relações de parentesco superestimadas". Ou seja, as relações reunidas no eixo vertical da primeira coluna, concernem à troca entre parentes de sangue que se aproximam, que "estabelecem uma forma de tratamento mais íntimo do que as regras sociais permitem" (Ibidem, p.30).

A segunda coluna, onde encontramos as relações "Os Espartoi se exterminam", "Édipo mata Laios" e "Eteócles mata Polinice", expressa o oposto da primeira coluna, ou seja, ela denota a proposição "relações de parentesco subestimadas ou desvalorizadas". Ela marca, portanto, uma relação de contradição, oposição com a 
primeira coluna ${ }^{12}$. Entretanto, para a compreensão das duas últimas colunas, uma série de condicionantes precisam ser detalhadamente explicitadas.

A ligação entre parentes consanguíneos, dá lugar, na terceira coluna, à relação conflituosa entre humanos e monstros, caracterizados, em especial, como monstros autóctones, nascidos da terra. Temos aí, "Cadmo mata o dragão" e "Édipo mata a Esfinge". O dragão como nos lembra Lévi-Strauss, é o monstro das profundezas que é preciso matar para que os homens possam nascer da terra, no caso os Spartoi, literalmente "homens semeados", que compreendem a linhagem que surge da terra após Cadmo, futuro rei de Tebas, semear os dentes do dragão. A esfinge, por sua vez, designaria, segundo Lévi-Strauss, "um monstro que, com enigmas que se referem à natureza humana, se empenha em retirar a existência de suas vítimas humanas". Esse feixe, portanto, ao agrupar assassinatos de monstros ctônicos, possui seu traço comum presente na desvalorização das relações entre humanos e monstros ctônicos, ou nos termos do antropólogo, "a negação da autoctonia humana".

Pois bem, se Lévi-Strauss seguisse o postulado de que um sistema mítico se funda na realização de um modelo analógico ou silogístico, teríamos no quarto e último feixe de relações a superestimação da proximidade entre humanos e monstros. Mauro Barbosa de Almeida, nos lembra que, por simetria com o primeiro feixe, teríamos uma relação que tomaria forma de uma proximidade íntima ou aliança entre humanos e entes ctônicos (ALMEIDA, 2008, p.152). Para nossa surpresa, esse pacote de relações não estão ausentes do mito de Édipo. Nas palavras de Almeida:

Ora, não seria preciso esforço para encontrar episódios precisamente deste tipo nas narrativas do ciclo de Édipo. Eles grassam em quase todas as gerações de descendentes de Cadmo, na forma de inter-casamentos entre a linhagem agnática de Cadmo e a linhagem dos Spartoi "autóctones". Depois de matar o dragão que guardava o local de Tebas, o adventício Cadmo consegue, graças a um ardil, exterminar quase todos os Spartoi.

\footnotetext{
${ }^{12}$ Como vemos na parte esquerda da fórmula canônica do mito, representada pela notação Fx
} (a) : Fy (b). 
Os Spartoi sobreviventes dão origem às grandes famílias de Tebas. Inicia-se um ciclo de conflito e aliança (Ibidem, p.153) ${ }^{13}$.

Entretanto, não é este o rumo que toma Lévi-Strauss na explicitação do quarto mitema. Como veremos, ele não apenas negou a relação analógica para a sua fórmula mítica, como substituiu a configuração da proposição predicativa, que definiu os três outros mitemas, pelo significado a ser extraído dos nomes próprios dos heróis da linhagem paterna de Édipo. Dessa forma encontramos, o caráter "pé-inchado" de Édipo, ligar-se ao caráter "manco" de Lábdaco e o caráter "canhestro, desconcertado" de Laios.

Ao recorrer à etimologia dos termos gregos, Lévi-Strauss transforma os nomes próprios - que, como nomes, possuem a característica particular de serem significantes sem significação partilhada, contextualizada - em termos a terem seu valor significante partilhado por um traço comum, no caso uma dificuldade de andar direito. Ora, apoiando-se no conjunto da mitologia ameríndia, em uma passagem que comentaremos à frente, Lévi-Strauss ressalta que, "em mitologia, os homens nascidos da terra são, com frequência, representados, no momento de sua emergência, como ainda incapazes de andar, ou andando desajeitadamente" (LÉVI-STRAUSS, 1955, p.232). O que o levaria a afirma que a coluna final agrupa, em última análise, o traço da persistência da autoctonia humana. De forma sintética, Lévi-Strauss apresenta qual seria, em sua leitura, a problemática central tratada pela totalidade do mito de Édipo:

Qual seria, então, o significado do mito de Édipo assim interpretado "à americana"? Ele exprimiria a impossibilidade na qual se encontra uma sociedade que professa acreditar na autoctonia do homem (cf. Pausânias: "O vegetal é o modelo do

\footnotetext{
${ }^{13} \mathrm{O}$ antropólogo brasileiro continua na exemplificação destas modalidades de relação no mito de Édipo: "Cadmo, Polidoro, Lábdaco, Laio, Édipo e Etéocles são representantes de seis gerações da linhagem de estrangeiros-fundadores de Tebas. Na primeira geração, o estrangeiro Cadmo, depois de matar o Dragão, dá sua filha Ágave como esposa a Ctônio, um dos Spartoi sobreviventes, enquanto seu filho Polidoro casa-se com a neta de Ctônio. Labdaco, filho de Polidoro, é órfão e, durante sua infância, a regência de Tebas cabe a Nicteu (filho de Ctônio). O filho de Labdaco, Laio, também é órfão e durante sua infância a regência de Tebas cabe a Lico (irmão de Nicteu, outro dos Spartoi). Édipo, filho de Laio, na infância vive exilado, enquanto a regência de Tebas cabe a Creonte. Assim, repetidamente a tirania em Tebas é alternada entre Labdácidas e Spartoi, com 8 labdácidas órfãos ou crianças refugiando-se fora da cidade e reassumindo a posição de tirano na idade adulta. Ao final desse ciclo, um "autóctone" (Creonte) condena à morte um labdácida (Etéocles, filho de Édipo) e também sua irmã Antígona, mas seu próprio filho Hémon se mata por amor a Antígona. Esses "feixes" tratam, assim, de um lado do antagonismo mas também da alternância política - entre autóctones e estrangeiros, e de outro lado da aliança de casamento entre autóctones e estrangeiros." (ALMEIDA, 2008, p.153).
} 
homem") de passar dessa teoria para o reconhecimento do fato de que cada um de nós na verdade nasceu da união de um homem e de uma mulher. A dificuldade é intransponível. Mas o mito de Édipo oferece uma espécie de instrumento lógico que permite lançar uma ponte entre o problema inicial - nasce-se de um ou de dois? - e o problema derivado, que pode ser aproximadamente formulado assim: o mesmo nasce do mesmo, ou do outro? ${ }^{14}$ (LÉVI-STRAUSS, 1955, p.233).

O recurso à mitologia ameríndia, representada por um mito dos Pueblo, se por um lado, responderia pela necessidade de demonstrar um método de análise estrutural que permitisse um tratamento da lógica mítica para além de sua origem históricogeográfica, por outro, influenciará diretamente na forma como o antropólogo lê e decompõe o mito de Édipo, ponto nodal para as críticas sofridas pela análise de LéviStrauss. Para compreender tais críticas, passemos, a partir de agora, à análise dos termos e relações implicados no modelo proposto para conceber a lógica das transformações míticas.

\subsection{O modelo paradigmático da fórmula canônica do mito}

No escrito que ora tratamos, após exemplificar a articulação própria dos mitemas a partir do mito tebano do Édipo e dos mitos zuñi de origem, encontramos pela primeira vez a notação e exposição detalhada da fórmula canônica do mito que, se acompanharmos as razões de Mauro Almeida, pode ser considerada "um dos tópicos mais intratáveis, fascinantes e persistentes da obra de Lévi-Strauss" (ALMEIDA, 2008, p. 147). Ela representa a primeira tentativa de análise estrutural do fenômeno mítico apresentado por Lévi-Strauss, ou seja, sua primeira incursão no campo de um modelo

${ }^{14}$ Uma leitura derivada desta investigação inicial de Lévi-Strauss foi realizada por Marilena Chauí, como vemos a seguir: "Essa referência aos pés e ao modo de andar é uma referência da relação dos humanos com o solo e, portanto, com a terra, e simboliza ou metaforiza uma questão muito grave: os humanos nasceram da terra ou da união de um homem e de uma mulher? Se da terra, deveriam ser imortais. No entanto, morrem. Para exprimir a angústia de serem mortais e que os humanos, portanto, nasceram de um homem e de uma mulher e não da terra, o mito simboliza a mortalidade através da dificuldade para se relacionar com a terra, isto é, para andar (coxo, torto, inchado). Para exprimir a dificuldade de aceitar uma origem humana mortal, o mito simboliza a fragilidade das leis humanas fazendo Laio mandar matar seu filho Édipo, Édipo assassinar seu pai Laio e casar-se com sua mãe, Jocasta"(CHAUÍ, 2000, p.205). 
lógico-matemático, nos moldes de uma combinatória algébrica, que trate da estrutura preexistente a toda narrativa mítica.

Deixada ao esquecimento por mais de trinta anos, acreditou-se tratar de um "abracadabra sem sentido" (LEACH, 1974 apud SCUBLA, 2001, p.124), um momento pouco feliz de suas formulações. Se por um lado, ao fim de sua incursão pelas grandes Mitológicas, Lévi-Strauss faz questão de aclarar o fato "de que nunca deixou de ser guiado por ela" (LÉVI-STRAUSS, 1981, p.538), será somente em A Oleira Ciumenta (1985) que o antropólogo retomará de forma mais extensa seu valor para a análise do fenômeno mítico.

Em A estrutura dos mitos, realizada a delimitação do mito como um fenômeno de linguagem, portanto passível de decomposição em unidades constitutivas mínimas que formariam um sistema, Lévi-Strauss apresenta aquela que seria estrutura básica diferenciadora entre os mitos e outros fenômenos narrativos. A emergência e necessidade desta formulação, como próprio das análises estruturais, seria extraída do conjunto de transformações do fenômeno em questão, posto que, ao se ordenar uma "série completa de variantes, na forma de um grupo de permutações, pode-se esperar descobrir a lei do grupo" (LÉVI-STRAUSS, 1955, p.246). Eis que o antropólogo francês nos apresenta ao seu modelo da seguinte forma:

A construção lógica de um mito pressupõe uma dupla permutação de funções. [...] Quaisquer que sejam os ajustes e modificações a serem feitos na fórmula abaixo, parece desde já estabelecido que todo mito (considerado como o conjunto de suas variantes) é passível de redução a uma relação canônica do tipo: Fx (a) : Fy (b) :: Fx (b) : Fa-1 (y). (LÉVI-STRAUSS, 1955, p. 245-6).

A leitura desta notação pode se dar nos seguintes termos: a um conjunto de elementos $a$ constituído pela função $x$ associado por oposição a um conjunto ' $b$ ' função de $y$ opõem-se outros dois conjuntos - equivalentes, mas não simétricos (RACINE, 2001, p.33) - que trazem além das 'trocas de parceiros' $(a, b, x, y)$, uma situação definida por uma inversão de termos e relações, sob duas condições: 
$1^{\text {o }}$ que um dos termos seja substituído pelo seu contrário $\left[\mathrm{a} \rightarrow \mathrm{a}^{-1}\right] .2^{\mathrm{o}}$ que uma inversão correlativa se produza entre o valor de função e o valor de termo de dois elementos [Fy $\left(\mathrm{a}^{-1}\right) \rightarrow \mathrm{F}$ a-1 (y)] (LÉVI-STRAUSS, 1955, p. 246)

A partir desta apresentação, Lévi-Strauss parte para a conclusão de seu artigo sem que dê maiores explicações de como tal permutação lógica se aplica necessariamente à interpretação de mitos, de modo que pudesse guiar eventuais tentativas de seus interlocutores frente aos mais diversos conjuntos de narrativas.

Por esta via, se partirmos do modo como o antropólogo apresenta o mito de Édipo, poderíamos estabelecer o quadro dos quatro mitemas de sua notação, nos moldes da fórmula canônica, da seguinte maneira:

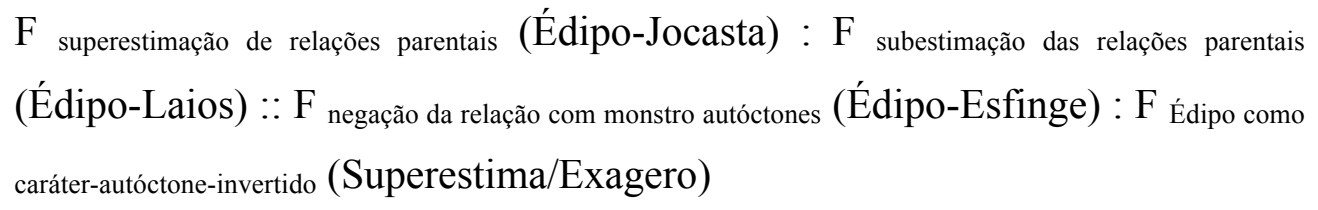

Nesta notação, na qual preenchi a título de exemplo apenas com elementos da narrativa de Édipo - ou seja, da versão congruente com a tragédia expressa em Édipo Rei - encontramos dupla torção do quarto elemento como expressiva da articulação entre os nomes próprios, no caso o de Édipo, e o predicado que lhe é associado, exagero, para além dos limites. Nos termos de Almeida:

O passo "transcendental" da dedução tem importantes consequências. Ele permite uma leitura como a seguinte: o incesto - no grupo consanguíneo de estrangeiros da linhagem de Cadmo - está para o parricídio/fratricídio - no interior da linhagem de Cadmo - assim como a guerra - contra os seres ctônicos/contra autoctonia - está para o caráter-disforme ctonismo "invertido", deslocado - de tiranos. O último passo leva ao tema seguinte: tiranos, que no limite negam a aliança em favor da exogamia, são assinalados pela desordem no andar e na comunicação. (ALMEIDA, 2008 p.154-55)

A dificuldade de locomoção, por esta via, seria uma das marcas indeléveis a que os tiranos, enquanto distorção política para a cosmologia grega, recebem por sua 
condição. Lembremos que o enigma central da narrativa de Édipo, proferido pela esfinge, "define o homem pela sua modo de locomoção, seu andar" (VERNANT, 1981, p.185). Os seres autóctones na forma humana, relacionados aos tiranos na construção de Lévi-Strauss, além deste traço na sua relação com a terra, são concebidos como agentes de comportamentos exagerados. Como comenta Almeida:

Ao colocarmos o fecho da fórmula como um caráterdistorcido de uma relação, apontamos na direção das sugestões posteriores de Lévi-Strauss (na Lição Inaugural de 1960) que associam o coxear a um distúrbio da socialidade (distúrbio da aliança e de diálogo), bem como na direção apontada por JeanPierre Vernant, que enfatiza o nexo entre incesto e tirania - duas formas de incapacidade de entabular relações sociais normais. (ALMEIDA, 2008, p.155)

Tais interpretações, decorrentes das próprias premissas do antropólogo francês em seu artigo dos anos 50, se contribuem para a explicitação da lógica na qual o sistema mítico se articula, não contem em suas proposições a unidade do conjunto do mito, queé representada, segundo Lévi-Strauss, por uma questão estrutural, no caso, uma questão acerca das origens: "nasce-se de um ou de dois".

Digno de nota é a aparição de uma menção especial à psicanálise para o conjunto de argumentação. Em um primeiro momento, Lévi-Strauss salienta o lugar da psicanálise no debate com a análise da mitologia tebana. Sua escolha não é sem precedentes, dada sua intensa abertura para o diálogo com a psicanálise. Assim como anteriormente reconhecera em Totem e Tabu um postulado com valor mítico, e, no interior do tratamento analítico, a existência de um mito individual produzido pelo neurótico, em A estrutura dos mitos, Lévi-Strauss mais uma vez concebe a empreitada freudiana como digna da mais alta consideração. Em seus termos:

O método nos livra, assim de uma dificuldade que, até agora, constituiu um dos principais obstáculo ao progresso dos estudos mitológicos, a saber a busca da versão autêntica ou primitiva. Propomos ao contrário, definir cada mito pelo conjunto de todas as suas versões. Esse principio é ilustrado por nossa interpretação do mito de édipo, que se pode basear na 
formulação freudiana, e certamente lhe é aplicável. [...] Continua se tratando de entender como um pode nascer de dois, como é possível que não tenhamos um único genitor, mas uma mãe e, além disso, um pai. Não hesitaremos, portanto, em colocar Freud junto com Sófocles entre nossas fontes do mito de Édipo, suas versões merecem o mesmo crédito que as outras, mais antigas e aparentemente mais "autênticas". (LÉVISTRAUSS, 1955, p.233-34)

Entretanto, para além do fato de sua análise da questão fundadora do mito de Édipo reverberar e se encontrar em estrita consonância com a compreensão psicanalítica dos fatores envolvidos no complexo edípico, Lévi-Strauss demonstra o papel seminal da teoria psicanalítica para o reconhecimento do valor e significação da fórmula proposta, fato este que corrobora o objetivo de mútua contribuição entre as duas disciplinas empreendido nesta dissertação. Sobre este valor, Lévi-Strauss nos diz:

A fórmula acima adquire pleno sentido quando lembramos que, segundo Freud, dois traumas (e não um só, como tantas vezes se tende a crer) são necessários para que nasça o mito individual que é uma neurose. Tentando aplicar a fórmula à análise desses traumas (postulando que satisfizessem as condições 1 e 2 enunciadas acima), certamente chegaríamos a dar à lei genérica do mito uma expressão mais precisa e mais rigorosa. Mas, principalmente, estaríamos em condições de desenvolver em paralelo o estudo sociológico e psicológico do pensamento mítico, talvez até de trata-lo como que em laboratório, submetendo as hipóteses de trabalho ao controle experimental. (LÉVI-STRAUSS, 1955, p.246-7)

Três pontos são essenciais nesta passagem: o primeiro, marca a convocação que o antropólogo faz aos psicanalista para que se detenham em tal formulação na explicitação daquele que podemos chamar o "mito individual que é a neurose", tal procedimento, em seus termos, seriam fundamentais para a explicitações dos determinantes lógicos do mito. 
Um segundo ponto a salientar, está no fato de que talvez aí o antropólogo esteja se referindo à aplicação que Lacan faz deste modelo na conferência $O$ mito individual do neurótico (1953a), apresentada dois anos antes do texto lévi-straussiano. Se, como veremos à frente, o psicanalista não o cita ou faz uma apresentação sistemática do modelo lévi-straussiano, este perpassa seu texto a tal ponto que Lacan compreende-se reconhecido por ter respondido à convocatória lévi-straussiana em seu empreendimento, mesmo que o antropólogo não tenha se referido a ele nominalmente. Em Análise estrutural em linguística e antropologia (1945), Lévi-Strauss, diante do progresso de formalização empreendido pela linguística, expressa que "os representantes das disciplinas vizinhas são, mais que autorizados, obrigados a verificar imediatamente suas consequências e sua possibilidade de aplicação a fatos de outra ordem" (LÉVI-STRAUSS, 1945, p.46).

No ano de 1951, como aponta Roudinesco, "Lacan, Benveniste, Guilbaud e Lévi-Strauss começaram a se reunir para trabalhar sobre as estruturas e estabelecer pontes entre as ciências humanas e as matemáticas" (1994, p.489). A relação próxima entre o psicanalista e o antropólogo, justificaria a congruência de seus trabalhos no início dos anos 50. Se Lacan, em $O$ mito individual, prontamente responde à convocatória de Lévi-Strauss, na seguinte passagem, de um encontro em 1956, podemos ver como ele enfatiza o fato de o antropólogo estar ciente de sua empreitada:

O relevo da coisa [(formalização de mitos)] é por mim altamente apreciado porque, como Lévi-Strauss não ignora, tentei quase de imediato e ouso dizer, com pleno sucesso, aplicar sua grade aos sintomas da neurose obsessiva [...] isso numa conferência que intitulei $O$ mito individual do neurótico (LACAN, 1956, p.90 - grifo meu).

Um último ponto a destacar está no fato de que a psicanálise, como representante da psicologia, também aparece como disciplina elementar do projeto de cada vez mais explorar os pontos de intersecção entre essas duas esferas de fenômenos, como vimos desde $A$ eficácia simbólica, e que ganhará importância em sua obra, a partir de $O$ Pensamento Selvagem, em 62, tratado à frente. Mas voltemos à fórmula e à leitura de seus termos. 


\subsection{Os desvios interpretativos da fórmula canônica no debate antropológico}

A fórmula canônica do mito, como dissemos, não instrumentou, por esta primeira exposição, qualquer mitólogo para uma análise discursiva do mito que the permitisse extrair seus determinantes estruturais. Ao contrário, a expectativa por novos detalhes de seu funcionamento, frustrou aqueles que nos anos 50 haviam se interessado pelo modelo de Lévi-Strauss. A partir dessa primeira aplicação, o modelo segue dois caminhos distintos: por um lado, ela praticamente desapareceu por mais de 30 anos do lugar de importância fulcral para a análise dos mitos, haja vista, sua ínfima incidência apenas duas rápidas menções - nos quatro tomos do maior empreendimento lévistraussiano no campo da mitologia, a saber, as grandes Mitológicas (LÉVI-STRAUSS, 1967, 1971). Sua volta triunfante (SCUBLA, 2001, p.124), como vimos, foi na segunda do conjunto de três obras denominadas de "pequenas mitológicas", A Oleira Ciumenta (1985), na qual se encontra 5 novas aplicações da fórmula, e que marcou uma revitalização na discussão do tema; por outro lado, aquele que busca se apropriar do funcionamento de sua notação não encontra em todas as aplicações de Lévi-Strauss um uso formalmente unívoco, uniforme.

Há desde o ano de 55, um movimento de ampliação do escopo de ação de suas análises que lhe tratar de fenômenos simbólicos que extrapolam o campo do mito, como revisto adiante. Até o ponto em que pude identificar aplicações e menções do modelo da fórmula canônica, encontramos na obra de Lévi-Strauss: em Estrutura e dialética (LÉVI-STRAUSS, 1956) a fórmula aparece como modelo para formalização das relações entre mitos e ritos de tribos, aldeias vizinhas; Em A gesta de Asdiwal (LÉVISTRAUSS, 1959), onde retoma seu valor para a análise de mitos; No curso de 1974-75, "Canibalismo e o disfarce ritual", no qual a opera para relacionar as máscaras do noroeste do pacífico (kwakiutl, pueblo, etc.) com as cerimônias naven dos Iatmul da Nova-Guiné (LÉVI-STRAUSS, 1984); Em 1985, com A Oleira Ciumenta, em que busca desfazer os mal-entendidos de seu potencial e retoma a fórmula; Em 1991, em História de Lince, quando analisa as narrativas em torno da gemelaridade; e, finalmente, em Hourglass configurations (LÉVI-STRAUSS, 2001), no qual faz uma peculiar aplicação à arquitetura de templos sagrados de diversos povos do mundo.

No esforço de compreender as funcionalidades da fórmula devemos abrir um parêntese para tratar da maneira pela qual o antropólogo se apropria das ideias 
matemáticas. Antes de estabelecer uma álgebra que possibilite o exercício de inúmeros cálculos, derivados de um algoritmo fundamental (Cf. COTÉ, 1995), Lévi-Strauss, com a criatividade de um bricoleur (ALMEIDA, 1990, p.367), compõe fórmulas como “desenhos, imagens, representações gráficas” (LÉVI-STRAUSS, 1983, p.13) que teriam a finalidade de "tornar mais simples a apreensão das cadeias de relações" (Ibidem). Deste modo, antes de compor regras positivas para a formação de um mito, tal fórmula terá, em nossa interpretação, o mínimo possível de condicionantes para o engendro das múltiplas variantes destes. Entretanto, esta não é a única leitura do esforço de matematização impresso no fórmula canônica do mito.

Diante da abertura de tal cenário, aquele que busca se dedicar às análises míticas depara-se com o fato último de que, todo e qualquer uso da fórmula depende de uma leitura particular sobre qual a noção de mito e quais aspectos privilegiar em sua apreensão. A pretensa pluralidade de leituras encontradas em Lévi-Strauss, cuja unidade há de ser desvelada, encontra ressonâncias e discordâncias no conjunto de seus sucessores. Entre aqueles que mais se dedicaram à exploração das potencialidades de formalização do modelo lévi-straussiano, encontramos teóricos como o folclorista, Pierre Maranda (MARANDA, 1971, 1980, 2001), o matemático, Jean Petitot (PETITOT, 1988, 1995, 2001), o antropólogo, Luc Racine (RACINE, 1989, 1990, 2001), o semioticista, Alain Coté (COTÉ, 1989, 1995, 2001), o filósofo e antropólogo, Lucien Scubla (SCUBLA, 1995, 1996, 1998, 2001) e o antropólogo brasileiro, Mauro Barbosa de Almeida (ALMEIDA, 1990, 2008). Tais investidas foram recebidas com entusiasmo pelo antropólogo. Em 1988, Lévi-Strauss expressa seu contentamento, em especial pelo contato com os matemáticos: "Sou incapaz de continuar, mas saber que alguns matemáticos não desprezam os aspectos formais do meu trabalho e levam a sério a análise dos mitos, é uma grande satisfação" (LÉVI-STRAUSS, 1988, p.176).

Deste grande conjunto de estudiosos, Salomon Marcus propõe a divisão entre duas leituras principais da fórmula canônica, leituras que não apenas diferem de como interpretar um mito, como destoam sobre qual termos da notação privilegiar em suas análises: de um lado, encontramos aqueles que, como Lévi-Strauss, compreendem um mito como um conjunto de narrativas (versões) que poderiam ser agrupadas e, a partir daí, extraídas as regras de transformação própria do mito. No interior desta perspectiva, o grande valor da fórmula canônica está em seu último termo, a dupla torção. Por outro lado, encontramos aqueles que se dedicam à leitura da fórmula como passível de ser 
aplicada a narrativas únicas, "a casos únicos com o objetivo de mapear sua fórmula geracional" (MARANDA, 2001, p.4). A fórmula canônica, por tal versão, especificaria uma "gramática gerativa" (ALMEIDA, 2008, p.169) do mito, que daria as bases, o método instrumental para a "construção" de uma versão, uma narrativa. Aqui a ênfase se dá sobre o papel do terceiro termo - o elemento b de Fx(b) - como mediador entre os dois pares de oposição. Vejamos mais detidamente este ponto, antes de tomar o valor da dupla torção.

Fazem parte desta última forma de compreensão da análise mítica a grande maioria dos estudiosos mencionados - à exceção apenas de Mauro Almeida. A leitura aí predominante é justamente a inaugurada por Pierre Maranda em Structural Models in Folklore and Transformational Essays, de 1971, e que privilegia o entendimento da fórmula como um construto morfodinâmico, cujos resultados estão delimitados à análise das tensões e inversões narrativas no interior de uma mesma história. A fórmula, portanto, seria um modo de expressar, e.g., a gesta de um herói exposto às contra-forças de toda sorte de vilania, cujo desfecho de sua extensa jornada apresentaria um retorno ao estado inicial, desprovido de grandes oposições, mas com um acréscimo (surplus) de atributos àquele que percorre toda a aventura, este expresso pela dupla torção. Nas palavras de Maranda:

A permutação ou "fazer o loop torcer sobre si mesmo" não constitui uma conclusão (ponto final); estamos lidando aqui com uma um passo helicoidal que traz uma nova situação: se um dado ator (a) é especificado por uma função negativa fx [...] (um vilão), e outro (b) pela função positiva fy (e assim tornando-se herói), (b) é capaz de assumir por sua vez a função negativa também, cujo processo leva a uma vitória muito mais completa na qual isso procede da ruína do termo (a) e então, estabelece definitivamente o valor positivo (y) da saída final. Dessa vez como um termo, (y) é especificado pela função que é o inverso de seu primeiro termo. (MARANDA, 1971 apud QUINN, 2001, p. 232-33 - tradução minha)

A apropriação de Maranda é bem expressa pela seguinte figura: 


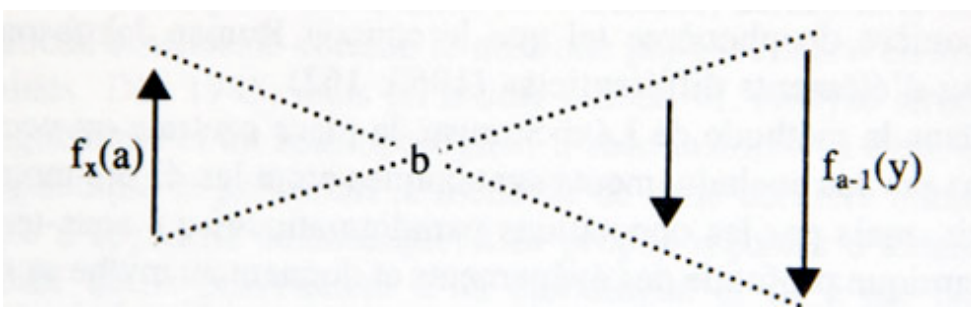

Como se vê, a ênfase na perspectiva diacrônica da narrativa é um dos traços marcantes das análises deste grupo. Por esta via, o papel de b, como mediador entre o primeiro par de funções opostas e o desfecho final da saga do herói, é acentuado em seu valor central para a constituição de uma narrativa mítica. O herói, lido nesta chave, após sua jornada, deixa de ser um personagem ingênuo e pretensamente puro, para congregar em si uma posição ambivalente, sendo a um só tempo herói e vilão, como bem representado pela narrativa edipiana. Ao tomar tal ponto de partida, Maranda se encontra inserido na tradição do modelo de análise apresentado pelo folclorista e formalista russo Vladimir Propp, pioneiro no estudo formal dos contos. Ao propor analisar a morfologia dos contos russos, Propp operou uma distinção entre forma e conteúdo oposta à presente no projeto estruturalista de Lévi-Strauss. A divergência foi o foco de estudo do artigo $A$ estrutura e a forma - reflexões acerca de uma obra de Vladimir Propp, na qual Lévi-Strauss busca delimitar o escopo de análise próprio de cada abordagem. Em seus termos:

Para o formalismo, os dois planos [forma e conteúdo] devem ser absolutamente separados, por só a forma é inteligível e o conteúdo não passa de um resíduo sem valor significante. Para o estruturalismo, essa oposição não existe: não ha de um lado o abstrato e, do outro, o concreto. Forma e conteúdo são de mesma natureza, passíveis da mesma análise. O conteúdo tira sua realidade de sua estrutura, e aquilo que chamamos de forma é a "estruturação" [mise en structure] das estruturas locais de que consiste o conteúdo" (LÉVI-STRAUSS, 1960, p.133)

Ao preconizar a análise morfológica das narrativas populares, Propp toma como premissa a divisão radical entre "um único nível morfológico, o das funções, e um nível amorfo, no qual se amontoam, personagens, atributos e motivações” (Ibidem, 
p.162). Como vimos, a busca de uma unidade metaestrutural das narrativas, redundou na obra de Propp e de seus sucessores na proposição de um modelo de regras que, aplicadas a conteúdos arbitrários, permitiria a proposição de um "arquiconto", de uma estrutura profunda a partir da qual poder-se-ia fabricar contos sintéticos e ver tais criações "ganhar vida, tornar-se realmente contos populares" (PROPP, 1928 apud LÉVI-STRAUSS, 1960, p.160). A dissociação entre os planos do significante e do significado, segundo o antropólogo, faria com que a estrutura engendrada por Propp incidisse sobre o objeto de análise a priori, e não a posteriori, como propõe na análise dos mitos.

Maranda e seu grupo, conjugando a fórmula lévi-straussiana a partir de tal perspectiva, justificariam a necessidade de seu procedimento como uma operação de supostamente reintroduzir à análise da estrutura mítica a dimensão do tempo, da diacronia (SCHWIMMER, 2001, p.60), portanto, de romper, em seus termos, com a tentativa "estática e infrutífera do estruturalismo como um todo, que se reflete na fórmula dos mitos tal qual proposta por Lévi-Strauss" (MARCUS, 1997 apud, COTÉ, 2001, p.218). Entretanto, tal aproximação engendra um duplo perigo para o estudo dos mitos: por um lado, empreende-se uma análise de discurso - cujo modelo lévistraussiano inaugura uma série de caminhos possíveis - mais próxima do formalismo que derivou no quadrado semiótico de Greimas (SCUBLA, 1998 apud MARANDA, 2001, p.315), ou seja um modelo que ao realizar a separação entre forma e conteúdo, esteriliza a potência da dupla torção, assim como a perspectiva histórica aí pressuposta; por outro, ela opera a redução da ambição universalizante do valor do estudo dos mitos, fazendo com que suas análises deixem de falar da transgressão de fronteiras semânticas, da onipresença da função significante nos fatos culturais, e passem a uma simples análise de narrativas. Na passagem a seguir, em correspondência a Salomon Marcus, Lévi-Strauss comenta distinção proposta entre os dois modos de compreensão da análise do modelo mítico:

Você [Marcus] distingue dois usos da fórmula, uma diacrônica e outra sincrônica. A primeira poderia ser ilustrada por Maranda (1971) que aplica isso à dimensão do tempo no interior das narrativas, enquanto eu uso a fórmula para manejar as variantes de um ponto de vista puramente formal. No entanto, mesmo meu uso dela implica um aspecto diacrônico. A variante 
que vem por último (o quarto membro da fórmula) está ligada a um evento que ocorre no tempo: ultrapassando bordas culturais ou linguísticas, emprestando de audiências estrangeiras, etc. [...] Devemos conceber a diacronia em duas vias: seja inscrita no tempo de uma narrativa especifica (le temps du récit), ou como a inscrição de muitas narrativas relacionadas em uma hiância de tempo externo (le temps historique) (LÉVI-STRAUSS, 1994 apud MARANDA, 2001, p.314)

Veremos adiante como Lévi-Strauss trata o evento em sua articulação com a fórmula canônica. Entretanto, devemos aqui ressaltar que, se os riscos de perder a essência da noção de estrutura do mito está presente na apropriação deste grupo de estudiosos, por outra perspectiva, é necessário reconhecer que tais trabalhos produziram uma retomada massiva do tema no interior da disciplina, expressa, além dos trabalhos já referidos, em empreendimentos coletivos como o número especial da revista L'Homme (v.135), de 1995, publicado exclusivamente na temática da fórmula canônica do mito, e o livro The Double Twist: From Ethnography to Morphodynamics, organizado por Pierre Maranda, com importantes reflexões sobre as possíveis compreensões do modelo de Lévi-Strauss.

Dentre os trabalhos mais significativos estão os artigos escritos por Lucien Scubla, nas duas publicações acima referidas. Se, por um lado, observamos como a leitura da fórmula canônica realizada pelo grupo organizado por Maranda deixa a desejar no que concerne ao seu potencial de formalização, devemos, por outro lado, reconhecer algumas das críticas aí expressas, como essenciais se quisermos eliminar a falta de precisão (SCUBLA, 2001, p.123) dos termos do modelo de Lévi-Strauss. Scubla dispõe as críticas à fórmula em quatro eixos principais: (1) seu campo de aplicação é pouco definido, falamos aqui de mitos (como em $A$ estrutura dos mitos), de relações entre mitos e ritos (assim como em Estrutura e dialética), de fases de ritos (à maneira de $A$ via das máscaras), e outros usos que vimos utilizados por Lévi-Strauss; (2) não está claro a universalidade de um mito, se são comparáveis independente de região ou cultura, ou se são polos, núcleos de difusão que aspiram universalidade; (3) cada aplicação procede de forma idiossincrática, sem uma relação necessária com outras, e permite inúmeras variações; (4) nenhuma das aplicações estabelece uma 
relação necessária entre formula canônica e materiais empíricos a ela supostamente ligados (SCUBLA, 2001, p.124-5).

A demanda por uma fórmula que especifique todas as passagens de uma narrativa, chega ao extremo de, sob a pena de Alain Coté, encontrar uma reflexão sobre todas as variantes matemáticas de notação da formulação, chegando a incríveis 144 formas de escrever a fórmula que, como o próprio Lévi-Strauss nos escreve em A Oleira Ciumenta, é "legítima em suas transformações desde que sejam respeitadas as condições iniciais: que um dos termos seja substituídos pelo seu contrário e que haja uma inversão entre um valor de termo e um valor de função“ (LÉVI-STRAUSS, 1985, p.171, nota). Entretanto, posteriormente, em diálogo direto com Coté, Lévi-Strauss estabelece uma nova condição: que a torção final - aquela que, como vimos, marca a abertura da fórmula estrutural para o evento, para a história - não fique no início da notação. Este foi um critério para que Lévi-Strauss negasse a validade de algumas das 144 variações propostas por Coté, justamente pelo fato de a dupla torção se responsável pelo enodamento, a posteriori, de um conjunto de oposições inconciliáveis (LÉVISTRAUSS, 1994 apud MARANDA, 2001, p.314).

Vejamos agora como as características da leitura da fórmula canônica sob a chave proposta por Lévi-Strauss, ou melhor, sob a perspectiva que podemos depreender da pluralidade de interpretações e usos que o antropólogo francês fez de sua notação.

\subsection{A dupla torção e suas implicações estruturais}

A via tomada por Lévi-Strauss, como vimos, foi desde o início a de considerar o mito como um conjunto de narrativas em torno de uma mesma problemática. Ao dissociar o valor mítico próprio de uma narrativa de sua forma intrínseca, de seu conteúdo dramático, o mito passa a ser considerado desde sua posição frente às distintas versões de uma história, cujas configurações semelhantes entre si, a despeito das distâncias históricas e geográficas, determinariam seu valor discursivo. Neste contexto, a temática das invariâncias e correlativas transformações estruturais ganha o estatuto de primeira ordem, tanto no interior de um mesmo mito, como em sua relação com outros mitos, estas bem assimiladas pelo duplo salto impresso ao fim do modelo lévistraussiano. 
Como podemos vislumbrar pela notação da fórmula canônica do mito, há em seu último termo o correspondente a uma dupla torção [double twist]: inversão entre termo e função, e negativação desta última. Esta representaria, nas palavras de Lacan:

A subsistência de um resíduo irredutível sob a forma de negativação de um dos quatro termos, que se impõe como correlativa à transformação do grupo: no que se lê o que chamaria de signo de uma espécie de impossibilidade da total resolução do problema do mito (LACAN, 1956, p.90).

Portanto, como bem nota o psicanalista francês, encontra-se nessa dupla torção do último membro uma abertura da estrutura mítica a uma quantidade in-terminável de narrativas, posto que, representando radicalmente a "lógica da ambiguidade" (VERNANT, 2002) própria do simbólico, torna suas produções, tão logo constituídas, "fadadas a serem pulverizadas para que, assim, novos universos nasçam de seus destroços" $" 15$ (BOAS, 1898 apud LÉVI-STRAUSS, 1955, p.221). Esta citação, escolhida como epígrafe de $A$ estrutura dos mitos, mostra o papel da consideração histórica própria do projeto de boas acerca da análise mitológica, para a formalização de sua estrutura, tal qual empreendida por Lévi-Strauss.

Um dos desenvolvimentos teóricos mais importantes de Lévi-Strauss para a possibilidade de representação desta dupla torção, encontra-se no modo como ele tratou a noção de mana em Introdução à obra de Marcel Mauss. Temos aí o papel seminal de um elemento sem precisa significação, sempre deslocado de si mesmo, estabelecido como condição de possibilidade para a constituição de um sistema estruturado. A noção de mana representaria, por tais razões, um elemento com "valor simbólico zero", função semântica que apenas expressa um

valor indeterminado de significação, em si mesmo vazio de sentido e, portanto, suscetível de receber qualquer um, cuja única função é preencher uma distância entre significante e o significado [...] em outras palavras, a superabundância do simbólico sobre o mundo a significar (LÉVI-STRAUSS, 1950, p.43).

\footnotetext{
${ }^{15}$ No original: "It would seem that mythological worlds have been built up only to be shattered again, and that new worlds were built from the fragments."
} 
Mana, como grau zero do sistema, expressaria a precedência do sistema significante. Este ponto será essencial tanto para conceber a partícula mínima do discurso mítico, o mitema, como formada por "elementos de significação em relação a um sistema significante suplementar" (LÉVI-STRAUSS, 1960, p.162), quanto para conceber a existência de um significante estruturante para um conjunto de elementos tal qual expresso pela inversão entre elemento e função $\left(\mathrm{F}_{\mathrm{a}}\right)$ - que sustente, ao mesmo tempo, o constante deslocamento, ou a abertura do sistema, expressa pela negação de sua determinação - como representado pela negação do elemento-função $\left(F_{a-1}\right)$. Se este é o princípio para a concepção formal da dupla torção em Lévi-Strauss, devemos ressaltar que ainda não está aí marcada a inserção da inscrição histórica, da lógica do evento na estrutura mítica futuramente proposta.

Uma das implicações deste passo na obra lévi-straussiana para a construção de modelos algébricos encontra-se no momento em que Lévi-Strauss expressa sua dúvida quanto à existência do dualismo diametral simétrico (CARNEIRO DA CUNHA, 2008, p.114), tal qual descrito em As Estruturas Elementares. No artigo As organizações dualistas existem?, de 1952, Lévi-Strauss descreve sua ingenuidade como responsável por acreditar na ilusão de que as metades diametrais de uma determinada organização social, por gerarem uma aparente simetria de sua estrutura, formariam um sistema fechado (LÉVI-STRAUSS, 1952, p.167). A suposta troca restrita entre duas metades de clãs, resguardaria um princípio de assimetria por conta da incompatibilidade das categorias utilizadas para sua representação entre os nativos em diferentes posições, como, por exemplo, o sistema dualista concêntrico e o diametral. O primeiro seria dinâmico e carregaria em si um triadismo implícito, cujo papel de mediar a assimilação da contradição, entre a tríade assimétrica e o dualismo diametral, revela seu duplo caráter, dual e triádico (Ibidem). A conclusão deste percurso é o de que a troca restrita é marcada por uma impossibilidade de simples assimilação de sistemas e que, portanto, deve ser tratada como um caso particular da troca generalizada (Ibidem, p.166).

No prefácio à segunda edição de As Estruturas Elementares, de 1966, LéviStrauss reapresenta a problemática através da análise do caso particular dos sistemas Crow-Omaha. Em seus termos:

Ninguém conseguiu ainda dar uma representação gráfica satisfatória de um sistema Crow-Omaha em um espaço 
de duas ou três dimensões [...] [este] nunca se cristaliza em uma forma estável. De modo sempre fugitivo e indistinto, unicamente seu espectro transparece aqui e ali em um meio fluido e indiferenciado. [...] Ao transformar parentes em afins, os sistemas Crow-Omaha fornecem a dobradiça graças à qual as estruturas de parentesco elementares e as estruturas complexas podem articular-se. (LÉVI-STRAUSS, 1966 [1949a], p.34-5)

A dificuldade de formalização deste sistema de parentesco está justamente no fato dele se constituir como um sistema fronteiriço entre os termos sociológicos presentes nas estruturas elementares e o caráter aleatório da rede de alianças, resultante de condições negativas (portanto, não prescritivas), próprio de estruturas complexas (Ibidem, p.35). O grande ganho destas reflexões foi a constatação de que mesmo no interior dos sistemas combinatórios elementares encontramos a inserção da história, do devir, como ponto de inflexão e torção da abertura do sistema como um todo. Mesmo que a história aqui não seja a da contingência, ou seja, de uma inscrição não passível de arranjo em uma série previamente dada, como Lévi-Strauss, a apresenta:

Embora virtualmente presente a todo instante, o conjunto das possíveis combinações é demasiado grande para poder atualizar-se a não ser graças a um tempo prolongado e somente por fragmentos. Da mesma maneira os sistemas CrowOmaha servem de ilustração do compromisso entre a periodicidade das estruturas elementares e seu próprio determinismo, que dependem de probabilidade (Ibidem, p.37)

Aqui tocamos diretamente a estrutura dos mitos. E a proximidade entre a características deste sistema aberto, passível de articulação entre história e estrutura, chegaram ao ponto de ser considerado pela historiadora Elizabeth Roudinesco o ponto de partida de Lacan para a formulação do sistema quaternário apresentado em $O$ mito individual do neurótico (LACAN, 1953). Em texto anterior (DOMICIANO; DUNKER, 2010), defendemos que se tal modelo estava à disposição do psicanalista, não precisamos, por questões historiográficas - em especial o fato de que a conferência lacaniana precede em dois anos A estrutura dos mitos, que como vimos, é o texto inaugural da reflexão lévi-straussiana acerca dos mitos - não precisamos supor que 
"Lacan inventa uma estrutura quaternária" (ROUDINESCO, 1993, p.294), estrutura esta que daria a Lacan a precedência da extensão da análise dos fatos de parentesco para o campo dos mitos. As bases do modelo de Lévi-Strauss para análise mitológica já estavam colocados desde 1952, nos cursos ministrados pelo antropólogo na EPHE, até mesmo os pressupostos para compreender a torção final de seu modelo, ali denominadas “transições irreversíveis” (LÉVI-STRAUSS, 1952-53, p. 244). Além de firmar-se como um protótipo de uma análise discursiva, a passagem para o campo dos mitos, também marcam a entrada em análise de "elementos difusos, ao invés de compactos do estudo sobre parentesco, e de grupos de transformações, no lugar do átomo básico" (DOMINGUES, 2012, p.158).

Essa passagem do parentesco à mitologia, portanto, coloca a questão de um sistema em que sua abertura representa tanto a entrada da diacronia na estrutura, quanto a representação da infinidade de possibilidades resumida no passo lógico da dupla torção final encontrada na formula canônica.

Sem correr o risco de realizar uma leitura teleológica, podemos afirmar que o essencial da fórmula encontra-se nesta inadequação do último termo ao estatuto dos demais, pois, como nos diz Luc Racine, "diferentemente da primeira oposição, a segunda - Fx (b) : Fa-1 (y) - articula elementos pertencentes a diferentes domínios, introduzindo uma oposição que distingue o último membro dos outros três" (RACINE, 2001, p.33).

Ela abre, por um lado, (1) a estrutura em jogo à noção de transformação, pois encontramos através de tal irredutibilidade, um incessante deslocamento de plano semântico, o que tornaria inteligível a noção de que todo mito seria essencialmente tradução de outro mito - "os mitos pensam-se a si mesmos através dos homens e à sua revelia" (LÉVI-STRAUSS, 1964, p.31) - possibilitando, assim, notar a importância de seu estudo para a apreensão objetiva da lógica do universo simbólico. Por outro lado, (2) este último termo, pela inversão de função e elemento, institui no mito um passo que podemos denominar, com Lévi-Strauss, de "dedução transcendental"16, ou seja, ele permite, para além do dados positivos e autocontidos daquela versão, a integração de elementos de mitos geográfica ou historicamente distantes (LÉVI-STRAUSS, 1985).

\footnotetext{
${ }^{16}$ De uma tríade auto contida deduz-se um quarto elemento transcendente.
} 
A fórmula canônica do mito, portanto, teria vindo à luz especialmente para representar a possibilidade de acesso a este "modo universal de organização dos dados da experiência sensível na fronteira entre a historicidade irredutível e as exigências intrínsecas ao pensamento transformador" (ALMEIDA, 2008, p.169). À possível estenografia de sintagmas completos, silogismos e analogismos (Grupos de Klein) de sua formação, tal qual empreendida pelo grupo de Maranda, Lévi-Strauss rebate com um construto que salienta a onipresença da função significante na organização "de outros grupos de ordens, escalas... ou dos mais distintos níveis de códigos"17 (DESVAUX, 1995). Se em uma frase pudéssemos resumir tal formulação, esta seria: os mitos se transformam, a partir de outros mitos (dados estruturais) e de eventos históricos (dados contingentes), mas, essencialmente, se transformam em uma dada direção da qual nada podemos dizer a priori, mas que podemos explicitar sua estrutura num segundo tempo. A noção de transformação impressa na raiz de tal formulação, vale dizer, é tão essencial que Lévi-Strauss chegará mesmo a declarar que

todos os erros, todos os abusos cometidos, sobre ou com a noção de estrutura, provêm do fato de que seus autores não compreenderam que é impossível concebê-la separada da noção de transformação. (LÉVI-STRAUSS, 1988)

O escopo de ação da noção de transformação é determinante, portanto, para a compreensão do que se entende por estrutura. Como vimos, no campo de análise do fenômeno mítico, o grupo liderado por Maranda, entende a estrutura como um modelo formal determinado à revelia dos elementos arbitrários que os encarnam. $\mathrm{O}$ valor da história e da diacronia estaria absolutamente ausente desta concepção de estrutura. A cada vez que fosse atualizada, realizada em um fenômeno, ela estaria totalmente apartada do conjunto de fatores particulares, contingentes que determinam a situação. Lévi-Strauss, por outro lado, compreende a estrutura como apreensível do conjunto de suas realizações em fatos imediatos. A multiplicidade de fenômenos, que correspondem aos diversos meios nas quais eles se encontra, são essenciais, portanto, para a

\footnotetext{
${ }^{17}$ Em o Cru e o Cozido (1964, p.246), Lévi-Strauss define os códigos como uma gramática e num léxico que sob a égide do mito, são transmitidos como invariantes. Ivan Domingues, exemplifica sua pluralidade: "Do lado do código haverá o código sensorial, ele mesmo dividido em códigos visual, olfativo, gustativo, tátil e auditivo; acrescente-se o código cosmológico ou astronômico, mais os códigos culinário, estético, moral, sexual e anatômico; por fim, o código sociológico, fundado em relações de aliança e de parentesco, cuja importância é decisiva." (2012, p.167)
} 
determinação de uma estrutura. Em outros termos, se a noção de estrutura permite um valor preditivo, não o é nas particularidades de sua efetivação, mas na regularidade de sua transformação, de emergência de múltiplas variantes de um dado fenômeno.

\section{A expansão da análise mitológica e suas derivas metodológicas}

Como vimos, o modelo da formula canônica foi abandonado por décadas do escrito lévi-straussiano. Uma das hipóteses para tal ausência esta no fato de que a partir do escrito em que ela aparece pela primeira vez, Lévi-Strauss encaminha um projeto de ampliação da lógica pressuposta no mito, haja vista sua analogia com outros campos, como o parentesco, e que culminará na proposta de $O$ Pensamento Selvagem e no método das Mitológicas, e toda a sistematicidade de uma análise no "gerúndio". Ao iniciar sua conclusão em $A$ estrutura dos mitos, o antropólogo anuncia tal possível expansão do escopo de análise:

Esse tipo de estrutura é especialmente digno de atenção na medida em que os sociólogos já o encontraram em dois outros campos, o das relações de subordinação entre os galináceos e outros animais (pecking-order) e o dos sistemas de parentesco, em que lhe demos o nome de troca generalizada. Ao isolá-lo agora num terceiro campo, o do pensamento mítico, pode-se esperar estar mais bem posicionado para perceber seu verdadeiro papel nos fenômenos sociais e dar-lhe uma interpretação teórica de alcance mais geral. (LÉVI-STRAUSS, 1955, p.246)

Eis o ponto de partida para uma investigação cada vez mais próxima entre sociologia e psicologia cujo parâmetro, como vimos, Lévi-Strauss importa da noção maussiana de tradução entre fenômenos coletivos e individuais, que chegará ao ápice na afirmação de que a "etnologia é, antes de tudo, uma psicologia" (LÉVI-STRAUSS, 1950, p.15). A busca por esse modo global de inteligibilidade presente na dita "mentalidade primitiva", levará à construção da importante categoria de "pensamento selvagem", que neste primeiro momento se institui como uma aposta: 
Talvez um dia descubramos que a mesma lógica opera no pensamento mítico e no pensamento científico, e que o homem sempre pensou igualmente bem. O progresso - se é que o termo se aplica - não teria tido por palco a consciência, e sim o mundo, em que uma humanidade dotada de faculdades constantes teria continuamente se deparado, no decorrer de sua longa história, com novos objetos. (LÉVI-STRAUSS, 1955, p.248)

Ora, no ano seguinte a busca por essa lógica percorreu à complexa relação dialética entre mitos e ritos. A possibilidade de análises cruzadas entre diferentes fenômenos estava posta na obra lévi-straussiana, a partir da descoberta desta ordem imperativa subjacente, interna (LÉVI-STRAUSS, 1964). Na ata do curso que sucedeu à empreitada pelos mitos, Lévi-Strauss escreve:

Entre os pawnee, essa complementaridade entre mito e ritual se manifesta de modo notável; é o que ocorre no caso dos costumes iniciáticos: os mitos e os ritos que se referem à iniciação das confrarias de feiticeiros-curandeiros oferecem estruturas rigorosamente idênticas, mas invertidas. Fomos então levados a postular a existência de um sistema psicossociológico subjacente, do qual a mitologia e o ritual constituem facetas. (LÉVI-STRAUSS, 1954-55, p.250)

A possibilidade de se pensar o fenômeno mítico como ordenado por um aparato de pensamento pré-subjetivo e separado da sua expressão narrativa, portanto, permite um movimento em seu entendimento da análise mítica, que passa a operar a partir de uma lógica próxima à postulada por um semiólogo, como Roland Barthes. Para este, o "mito é um modo de significação, cuja mensagem pode ser formada por diferentes tipos de representação, desde o discurso escrito, até a fotografia, cinema, reportagem, tudo pode servir de apoio à fala mítica” (BARTHES, 1957, p.212). O papel do mito como operado por uma lógica intrínseca e que demanda uma análise que expanda o modelo pelo qual se compreendeu a noção de mito até então, chegará ao extremo quando Lévi-Strauss postular tal operação global de inteligibilidade como 
própria ao pensamento selvagem, ou em sua alcunha menos conhecida, o pensamento mítico.

Em 1962, Lévi-Strauss começa por investigar uma questão histórica no interior do debate antropológico, a saber, o totemismo, e conclui que, enquanto qualitativamente distinto dos modos de apreensão ocidentais-científicos, ele se constitui como uma falsa categoria, posto que reduz-se à ilustração de um modo de reflexão, de um caso particular do problema geral das classificações (LÉVI-STRAUSS, 1962a, p.184). $O$ Pensamento Selvagem, livro que marca seu momento francamente estrutural (VIVEIROS DE CASTRO, 2008), virá em seguida para especificar o modus operandi do sistema classificatório dos povos ditos "selvagens", cujo papel condicionante da ordem do sensível, não o torna menos lógico e inteligível que o pensamento científicoconceitual. Ao demonstrar que há uma lógica classificatória inerente ao pensamento "selvagem", Lévi-Strauss "mostra que não existe um fosso entre o pensamento dos povos chamados primitivos e o nosso" (LÉVI-STRAUSS, 1988, p.142), posto que a função classificatória institui uma ordem no mundo que possui uma virtude frente a ausência de ordem, e fornece a base de todo e qualquer pensamento (LÉVI-STRAUSS, 1962, p.24). O pensamento selvagem, portanto, não é "do selvagem”, mas encontra aí uma expressividade que não se dá em nossa sociedade, na qual predomina o pensamento "domesticado", mesmo que não deixe de estar presente.

O modelo de funcionamento do pensamento mítico é descrito neste momento, pelo antropólogo, a partir de um procedimento técnico denominado bricolagem. Em suas palavras:

Em nossos dias, o bricoleur é aquele que trabalha com suas mãos, utilizando meios indiretos se comparados com os do artista. Ora, a característica do pensamento mítico é a expressão auxiliada por um repertório cuja composição é heteróclita e que, mesmo sendo extensor, permanece limitado; entretanto, é necessário que o utilize, qualquer que seja a tarefa proposta, pois nada mais tem à mão. Ele se apresenta, assim, como uma espécie de bricolage intelectual, o que explica as relações que se observam entre ambos. (LÉVI-STRAUSS, 1962, p.32). 
A ênfase aqui colocada está menos na possibilidade de análise combinatória, ou matematização dos elementos invariantes presentes no discurso mítico, e mais próxima da sua inscrição e pregnância na relação entre sensível e inteligível. A referida "composição heteróclita" do repertório do mitante, ou daquele que sustenta o pensamento mítico, se, por um lado, aponta para uma propriedade fundamental de uma análise que se queira estrutural, a saber, a possibilidade de explicitação da forma para além dos materiais com as quais tal estrutura se efetiva - que, como vimos, aparece no campo do mito desde A eficácia simbólica - por outro, recebe aqui um refinamento conceitual que permite a Lévi-Strauss analisar o discurso mítico menos em sua possibilidade de formalização e mais em sua determinação global da vivência imediata do homem, no caso, selvagens e ocidentais. Diferentemente dos mitemas, que denotavam relações entre relações, segmentos de história tornados significantes, os elementos deste modo de classificação recebem a seguinte insígnia:

Os elementos da reflexão mítica estão sempre situados a meio-caminho entre perceptos e conceitos. [...] Ora, existe um intermediário entre imagem e conceito: é o signo. Assim como a imagem, ele é um ser concreto, mas assemelha-se ao conceito por seu poder referencial: um e outro não se referem a si mesmos, podem substituir outra coisa. Todavia, o conceito possui uma capacidade ilimitada, enquanto que a do signo é limitada. [...] As combinações entre possíveis entre os elementos heteróclitos são sempre limitadas pela história particular de cada peça e por aquilo que nela subsiste de predeterminado, devido ao uso original para o qual foi concebido [...] a modificação que afete um elemento alterará automaticamente a estrutura toda, formando um arranjo novo. (LÉVI-STRAUSS, 1962, p.35-6 grifo do autor).

O foco deste modo de conceber o discurso mítico está justamente na explicitação de um modelo de produção de significações, cuja síntese significativa, precede e determina a estruturação dos elementos em jogo. A noção do mito como um discurso, ou antes, um metadiscurso cuja grade estrutural engendraria sua forma em distintos modelos discursivos, atinge aqui o auge do pensamento lévi-straussiano. 
Consolidada a estruturalidade e inteligibilidade desta forma de significar, a perspectiva que se toma na análise é essencialmente alterada para a maneira como se transformam diferentes mitos e como se articulam com as categorias empíricas.

Tal ênfase, serve de prelúdio ao método de análise mítica empreendido nos quatro tomos das Mitológicas (LÉVI-STRAUSS, 1988, p.95). Ao longo desta imensa obra, que se inicia em $\mathrm{O}$ Cru e o Cozido (1964), Lévi-Strauss percorre aproximadamente mil mitos colhidos desde a América do Sul até a América do Norte. Seu ponto de partida já nos chama a atenção por sua distinção frente ao método apresentado nove anos antes. Em seus termos:

Partiremos de um mito, proveniente de uma sociedade [os índios Bororo do Brasil Central], e o analisaremos recorrendo inicialmente ao contexto etnográfico e em seguida a outros mitos da mesma sociedade. Ampliando progressivamente o âmbito da investigação, passaremos a mitos provenientes de sociedades vizinhas, situando-os em seu contexto etnográfico. [...] montando inicialmente em torno de um mito o seu campo semântico, repetindo a operação para cada mito próximo, de modo que a zona central, escolhida aleatoriamente, possa ser recortada por vários percursos. Para obter uma varredura constante da mesma densidade, seria, portanto, preciso que o procedimento fosse refeito várias vezes, traçando novos círculos a partir de pontos situados na periferia. Cada progresso traz uma nova esperança, atrelada a solução de uma nova dificuldade. $\mathrm{O}$ dossiê nunca está completo. (LÉVI-STRAUSS, 1964, p.19-20)

Ao tomar um mito como passível de ser esclarecido, enriquecido pela análise cruzada com outros mitos vizinhos, leva o percurso de seu estudo a tomar o movimento particular de adensar sua leitura como em uma nebulosa, na qual, a medida que "se expande, seu núcleo se condensa e organiza, levando uma ordem a transparecer sob o caos" (Ibidem, p.21). Ora, diferentemente do que vimos no método pressuposto pela formula canônica, em que buscava a redução de dezenas de mitos a algumas regras de base, nas Mitológicas o método sofre uma ligeira modificação, como bem delimitado pelas palavras de Márcio Goldman: 
Nas Mitológicas o método estrutural é aplicado de outra maneira, no gerúndio, poderíamos dizer: a inteligibilidade dos mitos vai sendo revelada, vai sendo descoberta progressivamente, de forma imanente à própria análise. [...] Nestas não há “conclusão", e tem-se a impressão de que LéviStrauss, aí transita de um modelo epistemológico muito clássico - a explicação por meio de reduções progressivas - para um modelo propriamente estrutural em que não há redução de espécie alguma e o sentido se estabelece apenas com o movimento da análise (GOLDMAN, 2004, p.73-4 - grifos do autor).

Por esta chave metodológica a investigação deve caminhar de forma não linear, incapaz de responder a um plano preestabelecido, desse modo "em espiral, voltando regularmente a antigos resultados e englobando novos objetos apenas na medida em que seu conhecimento permita aprofundar um conhecimento até então rudimentar (LÉVISTRAUSS, 1964, p.22). Ao resumir a propriedade mítica de sua não completude, ou melhor, de sua constante mutação, tão logo constituídos, posto que são "intermináveis", Lévi-Strauss lê sua empreitada como respondendo metodologicamente a tal característica: frente a constante mutabilidade dos mitos, toda e qualquer tentativa de apreensão de um núcleo inteligível de suas narrativas, constituirá em um esforço fugidio, incompleto, em correlação com a natureza do objeto de estudo. Em outros termos, não faz das Mitológicas, a ciência dos mitos, mas o "mito da mitologia" (Ibidem, p.31). Portanto, mais do que explicitar as coordenadas simbólicas determinantes de um mito, Lévi-Strauss nesse momento "ouve" os mitos, confia em sua capacidade de dizer qual sua mensagem, posição e valor ${ }^{18}$.

Em As Estruturas Elementares, ao reconhecer o valor mitológico da narrativa impressa em Totem e Tabu, Lévi-Strauss não deixa de lançar uma crítica à opção psicanalítica de tratar uma questão, no interior de um meio científico, a partir do recurso a um mito - crítica esta que dotaria o modelo linguístico de um maior valor frente ao seu projeto de formalização dos fatos etnológicos (LÉVI-STRAUSS, 1949a, p.533). O projeto psicanalítico fora acusado de proceder, no campo da teoria, como um prático

18 "Os Ojibwa consideram os mitos como seres dotados de consciência, capazes de pensar e de agir.” (William Jones, 1919 apud LÉVI-STRAUSS, 1964, p.31). 
que, ao invés de explicitar por uma linguagem científica a totalidade dos determinantes da questão inerente à universalidade do Tabu do incesto, enuncia um juízo desde o interior dos conjunto que especifica sua questão, "reproduzindo o doente ao invés de interpretá-lo" (Ibidem). Ao forjar um mito para tratar do conjunto de variantes de outros mitos, apreendidos no contexto clínico, Freud teria realizado um projeto de formalização que, se em um primeiro momento, fora rechaçado por Lévi-Strauss, a partir dos anos 60 será concebido como um modelo inerente à própria lógica mítica, e portanto, exemplar em sua análise mitológica.

Como vimos, uma das possíveis hipóteses da pouca incidência do modelo da fórmula canônica é a potência e extensão do modus operandi da análise apresentada nas mitológicas, assim como sua diferença fundamental com a abordagem sustentada até então. Entretanto, anos após a finalização da realização do projeto das Mitológicas, mais particularmente na Oleira Ciumenta, de 1985, o antropólogo é enfático em situar que nunca deixou de guiar-se pela fórmula apresentada na década de 50. Certamente não há uma simples sobreposição dos modelos, entretanto, ao levar a afirmação do antropólogo a sério, poderíamos conceber tal diferença de perspectiva como proveniente não de uma evolução teórica ou de uma mudança epistêmica que faria com que o primeiro modelo pudesse ser descartado como menos acurado ou mesmo incorreto, e sim, como fornecendo duas possíveis passos lógicos passíveis de coexistência e mesmo de intrínseca articulação. Além dos postulados que sustentaram sua opção metodológica nas Mitológicas, que vimos acima, o antropólogo sustenta ainda uma limitação decisiva para sua escolha. Questionado por Didier Eribon sobre o motivo pelo qual não teria procedido pelo mesmo modelo de A estrutura dos mitos, Lévi-Strauss responde:

Algumas vezes falei sobre isso com matemáticos. Alguns disseram-me que seria possível, mas muito difícil para mim, e eles tinham coisa melhor para fazer. O problema levantado em As estruturas do parentesco originava-se diretamente da álgebra e da teoria dos grupos de substituições. Os problemas apresentados pela mitologia parecem indissociáveis das formas estéticas que os objetivam. Ora, estes pertencem, ao mesmo tempo, ao contínuo e ao descontínuo [...] Poderíamos, também, pensar no computador. Estou informado de tentativas feitas além-Atlântico para refazer $O$ cru e o cozido. 
Mas isso toma um tempo desproporcionado [...] conseguiram engendrar os cinco primeiros mitos quando, com meus processos artesanais, eu já havia deslindado algumas centenas; não sem deixar vários numa certa "delicadeza artística", evidentemente. (LÉVI-STRAUSS, 1988, p.177)

Valendo-nos da referência metafórica aos procedimentos de formalização próprios à psicanálise, poderíamos tratar o procedimento próprio às Mitológicas, como homólogas aquelas utilizadas no decorrer de um tratamento e mesmo de um relato de caso clínico, ao passo que a fórmula canônica assemelhar-se-ia à postulação de princípios fundamentais de estruturação do psiquismo, ou a uma apresentação metapsicológica tão presente na reflexão psicanalítica e da qual o próprio antropólogo reconhece a proximidade com sua abordagem.

\subsection{A questão da língua e a crítica ao formalismo da análise mitológica}

Com Lévi-Strauss, como vimos, a temática do mito encontra uma profundidade na formalização de seus determinantes estruturais sem precedentes na história da disciplina. Também podemos dizer que o papel aí desempenhado pela reflexão psicanalítica, como um importante suporte epistemológico, é marcado por um ineditismo que ainda hoje persiste como o maior ponto de interlocução no interior da reflexão antropológica.

No percurso que traçamos neste capítulo, longe de esgotarmos as reflexões de Lévi-Strauss sobre a análise mitológica, visamos privilegiar três momentos fundamentais da compreensão e operatividade da categoria de mito em sua obra: em um primeiro momento, o mito aparece como uma noção auxiliar, na busca da legitimação das conclusões superestruturais de As Estruturas Elementares. Com A eficácia simbólica, o mito aparece como um índice da onipresença simbólica nos fatos humanos, a ponto de sua veiculação, desde que respeitando algumas regras fundamentais, permitir mudanças físicas e psíquicas, e no caso de um tratamento, responder pela possibilidade da cura.

Vimos como A estrutura dos mitos, em um momento posterior, resulta de uma inflexão do método estrutural que aqui se debruça especificamente sobre o fenômenos 
mítico e que já tem suas bases derivadas de importantes releituras da noção de estrutura. Ao considerar o mito como um dispositivo meta-discursivo que engendraria narrativas centradas em torno da tentativa de mediação de uma contradição primeira, e cujas equivalências envolvem a inserção de um elemento anamórfico frente aos demais, LéviStrauss reposiciona globalmente o mito como uma instância privilegiada de acesso aos determinantes de um modo de pensamento especificamente predominante em sociedades não-domesticadas, mesmo que condicionantes de todo e qualquer pensamento.

Finalmente, traçamos as principais coordenadas da elevação da lógica mítica ao modo de significação, de articulação entre elementos heteróclitos para a classificação geral e articulação entre os planos do sensível e do inteligível, tornando-se assim, na esfera das representações, um índice do campo da experiência totalizante própria deste pensamento selvagem. O papel de reorganização da experiência sensível, responde por uma extensão da lógica significante própria ao pensamento mítico que torna compreensível seu papel seminal na obra lévi-straussiana por mais de três décadas.

Feitas tais distinções, um importante aspecto que permeia a diferenciação entre estas concepções de mito na obra lévi-straussiana parece emergir como um índice relevante a considerarmos quando notarmos seu valor para a reflexão psicanalítica: encontramos aí um gradativo deslocamento das análises do mito tanto de sua narrativa, quanto dos aspectos relativos à inserção de sua veiculação em linguagem corrente, ou em uma língua nativa.

No primeiro momento, temos, além da eficácia relativa ao papel ambíguo dos termos presentes no interior da verbalização do mito, o papel uniformizante de uma narrativa, em sua capacidade de fornecer uma rede de significações na qual uma pessoa possa ancorar sua experiência fragmentária. Mais tarde, em $A$ estrutura dos mitos, ao conceber a matéria do mito como uma "linguagem que trabalha em um nível elevado, descolado do fundamento linguístico no qual inicialmente rodou" (LÉVI-STRAUSS, 1955, p.224), o antropólogo insere a lógica mítica como um modo de discurso, metadiscurso, cujo valor de pregnância linguageira, com todos os efeitos para a possibilidade de tradução, ou nos seus termos, o valor da fórmula traduttore tradittore, seria equivalente a zero. Entretanto seus elementos básicos ainda estão sustentados no interior do conjunto de narrativas, como fragmentos da história que denunciam relações entre 
relações, em outros termos, "a substância do mito não se encontra nem no estilo, nem no modo da narração, nem na sintaxe, mas na história que conta"(Ibidem, p.232). A partir da emergência do conceito de pensamento selvagem, o traço mítico passa a ser a capacidade de combinação de distintos códigos (cosmológico, físico, moral, jurídico, social, etc.) e materiais (expressões gráficas, escritas, verbais). A propriedade de articulação significante sobre o domínio do sensível prevalece sobre sua articulação no nível do contexto geral da veiculação da narrativa.

Este gradual distanciamento reflete em uma crítica considerada "muito séria e digna de atenção" por Lévi-Strauss no Finale, capítulo que encerra a série das grandes Mitológicas: esta é justamente aquela realizada por linguistas que o recriminam pelo fato de, apenas ocasionalmente, "levar em conta a diversidade das línguas em que todos os mitos foram originalmente pensados e enunciados, mesmo que nem sempre nelas registrados" (LÉVI-STRAUSS, 1971, p.620). A tal postulado crítico, Lévi-Strauss responde através do argumento da inviabilidade de se levar a cabo tal empreitada devido às suas competências linguísticas, ou à falta de competências. Entretanto, um argumento inerente ao objeto aparece em primeiro plano em sua resposta:

Todo mito é, por natureza, tradução. Origina-se de outro mito, proveniente de uma população vizinha mas estrangeira, ou de um mito anterior da mesma população, ou ainda contemporâneo, mas pertencente a outra subdivisão social [...] Se o estudo filológico dos mitos não constitui uma precondição absoluta, isso se deve ao que se poderia chamar sua natureza diacrítica. Cada uma de suas transformações resulta de uma oposição dialética a outra transformação. [...] Encarado de um ponto de vista empírico, todo mito é a um tempo primitivo em relação a si mesmo e derivado em relação a outros mitos; não se situa em uma língua e em uma cultura ou subcultura, mas no ponto de articulação destas com outras línguas e outras culturas. De modo que o mito nunca é de sua língua, é perspectiva sobre uma língua outra, e o mitólogo que o apreende por intermédio de uma tradução não se sente numa situação essencialmente diferente da de seu narrador ou ouvinte na terra natal. (LÉVI-STRAUSS, 1971, p.621-22) 
Deriva deste argumento, que se aproxima dos postulados de $A$ estrutura dos mitos, duas importantes consequências, desde muito expressas em sua obra: a primeira é a representação do mitante, como um particular que atualizaria um modo universal de significação, que subsiste independente de qualquer subjetividade, ou à despeito de todas. O sujeito aí implicado, como veremos na contraposição efetuada pela leitura lacaniana do mito, em sua posição singular está reduzido a nada, não passa de um composto de encruzilhadas estruturais plenamente determinadas (Cf. LEVI-STRAUSS, 1978). Outra consequência, esta mais diretamente extraída da citação, configura-se pelo deslocamento do conhecimento da língua original, a um conhecimento de segunda categoria. "Não supérfluo", como aponta o antropólogo, mas apenas acrescentando "dimensões suplementares, dando ao estudo do mito mais volume e relevo, entretanto, sem afetar, no essencial, o conteúdo semântico" (LEVI-STRAUSS, 1971, p.622).

Neste cenário desponta ainda uma crítica que opera de modo relativamente inverso à dos linguistas, e talvez, por isso mesmo, mais potente em suas repercussões. Ela se encontra presente em inúmeros antropólogos - em particular, culturalistas dentre os quais destaco Schwimmer (2001) e Salomon (1993): a despeito de todo esforço de formalização matemática, de descolamento da lógica mítica de seus elementos imediatos, em especial, a cultura em que emerge e o sistema da língua em que é veiculado, Lévi-Strauss não deixa em nenhuma apresentação de suas análises de situar o "contexto", ou a situação cultural em que tal mito está envolvido (SCHWIMMER, 2001, p.57). Crítica que, no que se refere ao modelo de formalização da fórmula canônica do mito, insere um princípio de indeterminação que dificulta a extensão do seu uso aos seus sucessores. No entanto, antes de contradizer a crítica dos linguistas - pois não defende que ele faça extensas análises linguísticas, posto que ao longo de sua obra encontramos tais referências culturais apresentadas de maneira fragmentária - ou de buscar refutar o valor de suas conclusões gerais e universalizantes em prol de um relativização do sistema do mito, tais críticas nos lançam as seguintes questões: seria possível pensar na leitura lévi-straussiana do mito de Édipo, de Asdiwal ou da Oleira ciumenta, para tomar apenas aqueles que tiveram sua matriz lida através da fórmula canônica do mito, seria possível pensa-las sem um conhecimento maior da língua em que estavam inseridos? A resposta de Lévi-Strauss seria, decerto, positiva, entretanto, a explicitação desses determinantes não colocariam à análise do mito um elemento cuja significância fosse primordial para a leitura global do nó de 
transformações aí implicados, em especial, para a concepção da dupla torção? O tour de force aqui proposto, em tese, se insere na retomada da leitura do mito enquanto matriz estrutural a partir de suas concepções primárias sobre a ambiguidade fundamental da narrativa mítica, tal qual apresentada em A eficácia simbólica.

$\mathrm{Na}$ apresentação da análise que Lévi-Strauss propõe acerca do mito de Édipo, vimos como sua estrutura, tal qual preconizada pela fórmula canônica, é condicionada pela dupla torção final, que, no caso da lenda tebana, foi expressa pela tradução em termos de relações sociais, dos nomes de Édipo, Laios e Lábdaco. Teria o antropólogo chegado ao mesmo desfecho em sua análise caso não tivesse uma formação na língua de origem do mito? Nossa hipótese fundamental aqui é de que o método proposto para a explicitação formal da lógica mítica, não pode ser descontextualizada do conjunto semântico do qual procede. Em outros termos, de que a leitura da estrutura deve, como Lévi-Strauss não discordaria, estar intimamente de uma leitura histórica e linguística. Vejamos a partir daqui como uma contextualização levaria a críticas de sua proposta de análise no caso do mito de Édipo, e, consequentemente, a que conjuntos de questões poderiam nos lançar tal empreitada.

\section{O mito de Édipo e suas derivas ameríndias: uma releitura crítica}

Ciente da configuração preliminar de seus postulados, Lévi-Strauss, em $A$ estrutura dos mitos, reiteradamente alerta para as possíveis críticas que receberia dos estudiosos do mundo grego, principalmente pelo caráter sintético de sua leitura, portanto, deixando de lado uma série de traços que talvez não fossem considerados secundários entre seus pares. Como um adivinho, o antropólogo previra as várias investidas que receberia ao longo dos anos dos helenistas, entre os quais podemos destacar Jean Pierre Vernant, Michael Carroll, Terence Turner, Pierre Vidal-Naquet, para ficar com os mais expressivos.

Uma das primeiras e mais incisivas críticas procede do antropólogo americano M. P. Carroll, em um artigo de 1978 publicado na American Anthropologist, uma das mais conceituadas revistas da disciplina, intitulado Lévi-Strauss on the Oedipus myth: a Reconsideration. A principal via tomara por Carroll é a da investigação sobre a pretensa unidade das proposições agrupadas nos mitemas propostos por Lévi-Strauss. O que está 
aqui em jogo, como nos lembra Ordep Serra - mas também expresso na maioria dos estudiosos reunidos por Maranda - é o valor de formalização do modelo de LéviStrauss, ou seja, o quanto de sua construção na análise do mito de édipo não se funda em um procedimento intuicionista (SERRA, 2007, p.235).

Ao considerar a unidade dos mitemas, Carroll concorda que as relações reunidas sob o mote da subestimação das relações consanguíneas formem um conjunto, apresentem um traço comum (CARROLL, 1978, p.806). Entretanto, o antropólogo americano discorda da leitura de Lévi-Strauss acerca do primeiro mitema, ou seja, daquele que denota as relações consanguíneas superestimadas. No caso da ligação entre Édipo e Jocasta, tal relação pode ser sustentada, posto que, "dada a universalidade do Tabu do incesto, o casamento de um filho com sua mãe parece indicar uma relação de parentesco mais intima do que ela deveria ser" (Ibidem).

O mesmo, no entanto, não podemos dizer sobre as proposições "Antígona enterra Polinice" e "Cadmo procura Europa". Acerca desta última, Carroll nos diz:

Consideremos as partes da história "Cadmo-procura-suairmã” que Lévi-Strauss não menciona: (1) Zeus sequestra Europa; (2) O pai de Europa, Agenor, envia seus três filhos (Cilix, Fênix e Cadmo)e seu neto Thasso procura-la; (3) Cilix, Fênix e Thasso rapidamente desistem de procurar e assentam-se em varias áreas; (4) Cadmo e sua mãe continuam a busca; a mãe morre e Cadmo consulta um oráculo; o oráculo lhe diz para abandonar a procura e fundar uma cidade (que será Tebas). O que nesta história sugere de relações de parentesco mais íntimas do que deveriam ser? Certamente não o fato de Cilix, Fênix e Tasso, todos parentes próximos de Europa, rapidamente abandonam a busca, a despeito da instrução de seu pai. Mesmo Cadmo eventualmente abandona a busca sem aparentemente se arrepender e inclina-se a outros objetivos. Ao contrário, o fácil abandono da busca por Europa por seus parentes próximos deve sugerir uma desvalorização (não supervalorização) de relações de parentesco. (Ibidem, p. 807)

A mesma disparidade com relação ao padrão postulado do mitema, ocorre com o caso de Antígona, mas, devemos ressaltar, com um agravante: no interior do contexto 
do pensamento grego, a decisão de Antígona de enterrar seu irmão, não marcaria um exagero ou um excesso de intimidade frente a um comportamento esperado por seu grau de parentesco, mas seu contrário. Se há, antes, uma ação que causa espécie é a “decisão de creonte de proibir o enterro de seu sobrinho [...] O horror gerado pelo insepulto e pelo enterro do vivo, indicaria, mais claramente, a subestimação das relações de parentesco" (Ibidem, p. 808). Portanto, se bem analisado, este mitema por seu conjunto traria posições não apenas distintas, como opostas em sua essência.

A crítica de Carroll continua pelas colunas 3 e 4 . No que concerne ao assassinato dos monstros ctônicos, como "negação da autoctonia do homem", o antropólogo americano sustenta que nem o dragão morto por Cadmo, nem a esfinge destruída por Édipo seriam seres autóctones. Em outras palavras, tanto um como outro, teriam nascido da união entre um macho e uma fêmea: no caso do dragão entre Gaia (Divindade que personifica a Terra) e Ares (Deus da Guerra) ou entre Afrodite (deusa do Amor) e Ares, a depender da tradição; já no caso da esfinge, as principais tradições do tema, trazem seu surgimento como decorrente da união de Typhon e Echnida, ou pela junção de Echnida e Orfus. De qualquer maneira, a morte dos dois monstros não indicariam, pela análise de Carroll, a negação da autoctonia, mas antes a negação da origem sexual, de dois seres.

A justificativa dada por Lévi-Strauss, em uma nota de rodapé para sua opção de considerar a esfinge um ser advindo das profundezas da terra, mostra-se reveladora para a crítica do último mitema, assim como para o conjunto de sua interpretação do mito de Édipo. Nesta, após reconhecer sua leitura como um exemplo tratado arbitrariamente e acolher a leitura de Marie Delcourt (1944) sobre as lendas arcaicas da autoctonia da esfinge, ele revela que escolheu "o mito de Édipo como primeiro exemplo em razão das notáveis analogias que parece haver entre certos aspectos do pensamento grego arcaico e o dos índios Pueblo" (LÉVI-STRAUSS, 1955, p.232). Feita tal constatação, Lévi-Strauss aponta duas entidades ameríndias, em especial presentes entre os Hopi e os Pueblo, correlatas à função da esfinge na cosmologia grega, de modo a confirmar sua leitura do caráter autóctone da esfinge.

Vemos nessa passagem que o antropólogo, em sua apresentação da análise dos mitos, não hesita em considerar a mitologia grega a partir de outras mitologias, como no caso, a ameríndia. Esta posição não deveria causar espécie a uma análise que tem como 
premissa a determinação de uma estrutura translinguística, ou seja, que transcende seu campo de ordem linguística (GEORGIN, 1983, p.35), portanto, que conecta mitos de regiões geográficas ou entre domínios históricos distintos (ALMEIDA, 2008, p.154). Eis justamente o escopo de ação da fórmula proposta pelo antropólogo. Mas tomemos a influência do pensamento ameríndio sobre o quarto mitema.

Consideremos primeiramente a forma como Lévi-Strauss justifica, após apresentar os detalhes da negação da autoctonia, sua escolha pelos nomes próprios de Édipo, Laio e Lábdaco:

Essas hipóteses ajudam a entender o sentido da quarta coluna. Em mitologia, os homens, nascidos da terra, são com frequência representados, no momento de sua emergência, como ainda incapazes de andar, ou andando desajeitadamente ${ }^{19}$. Entre os Pueblo, por exemplo, os seres das profundezas, como Shumaikoli ou Muyingwû, que participam da emergência, são mancos (nos textos são chamados de "Pé-ensanguentado", "Pémachucado", "Pé-mole") A mesma observação vale para os Koshimo da mitologia kwakiutl [...] O traço comum da quarta coluna poderia ser, portanto, a persistência da autoctonia humana (LÉVI-STRAUSS, 1955, p.232 - grifo do autor)

Ora, a relação entre a dificuldade de locomoção e o caráter autóctone, surge, portanto, de uma projeção dos modelos americanos sobre a mitologia grega, na qual não há "nenhuma menção de que seres autóctones sejam mancos ou de que seres mancos sejam autóctones" (CARROLL, 1978, p.809), fato que justificaria Lévi-Strauss não citar nenhum exemplo do ideário grego como o fez dos ameríndios. Mesmo entre os três heróis referidos, não há nenhum episódio nas narrativas acerca de sua dificuldade de andar ou origem ctônica. Sobre este ponto, Vernant nos diz:

Lévi-Strauss foi o primeiro a destacar a importância de um traço comum às gerações da linhagem do Labdácidas: um desequilibro do andar (Lábdaco), uma falta de simetria entre os

\footnotetext{
${ }^{19} \mathrm{Na}$ primeira versão do texto, em inglês, encontramos uma ênfase maior nesta ideia: "Em mitologia é um caráter universal dos homens nascidos da terra que, no momento em que emerge das profundezas, eles não podem andar, ou fazer isso com desenvoltura” (LÉVI-STRAUSS, 1955c, p.434)
} 
dois lados do corpo (Laio), um defeito em um dos pés (Édipo). [...] Inicialmente Lévi-Strauss acreditou poder ler esses nomes de personagens gregas que evocam um defeito do andar à luz dos mitos ameríndios [...] Interpretação difícil de sustentar, pois a aplicação de modelos americanos aos fatos gregos revela-se gratuita e arbitrária (VERNANT, 1981, p.179)

O helenista, seguindo aqueles que criticaram tal apropriação lévi-straussiana, cita ainda, a título de exemplo desta falta de correlação entre autoctonia e andar disforme para o pensamento grego, a própria mitologia de Tebas na qual os Spartoi "homens semeados" por Cadmo a partir dos dentes do dragão - tão logo saem da terra, já adotam a postura ereta.

A despeito da crítica ácida que faz à leitura de Lévi-Strauss sobre a mitologia de Édipo, Vernant não deixa de reconhecer seu valor, posto que $A$ estrutura dos mitos "modificou tão radicalmente o campo dos estudos mitológicos que, a partir dela, em Lévi-Strauss e em outros sábios a reflexão sobre a lenda édipiana seguiu caminhos novos e, creio, fecundos" (Ibidem). Ele mesmo propôs uma retomada da análise de Édipo depurada das interferências do pensamento ameríndio. A ênfase de sua interpretação, não se encontra tanto no caráter autóctone, de um questionamento sobre as origens, como em uma reflexão política, sobre os limites da vida em sociedade. No comentário de Almeida:

A dificuldade de andar direito, uma anomalia da exis, aplica-se a pessoas que são também culpadas de abuso sexual com pessoas próximas (caso de Laio e de Édipo), ou que são tiranos, com uma anomalia comunicativa, o que leva ao tema do enigma respondido e do oráculo sem resposta, bem como ao tema da tirania como distorção política. [...] Leituras sucessivas relacionaram o tema do "desequilíbrio do andar" ao incesto (irmão-irmã, mãe-filho), ao abuso da linguagem na forma do enigma, ao abuso de poder na forma (ALMEIDA, 2008, p.156-7)

A via tomada por Vernant, na elevação do estatuto do caráter disforme do andar e consequente associação com a tirania, levou-o a identificar um conjunto de narrativas míticas espacialmente próximas das tebanas que poderiam se configurar 
como uma das transformações do mito de Édipo. Esta diz respeito à "narrativa 'histórica', presente em Heródoto, da dinastia dos tiranos de Corinto, os Cipsélidas, oriundos de Labda, a Coxa" (VERNANT, 1981, p.181). De maneira geral, temos a narrativa de uma linhagem de tiranos endógamos que encontra a ruína em um casamento externo de Labda, rainha coxa de Corinto. Há aí, também, uma profecia oracular que descreve o fim da linhagem: "Rei de Corinto, tu, teu filho, mas não os filhos dos teus filhos" (Ibidem, p.196) ${ }^{20}$.

Neste contexto crítico, devemos inserir ainda uma revisão do estudo de $A$ estrutura dos mitos, de autoria do própria Lévi-Strauss, cuja análise será de grande valor para a exploração de nossa hipótese. Esta na Aula Inaugural proferida quando de sua entrada no Collège de France, em 1960. Esta aula marca um retorno aos termos de sua análise do mito de Édipo, que segundo Vernant, marca uma obsessão do antropólogo, que o retoma sempre que possível (VERNANT, 1981, p.180). Nesta releitura, ainda que de breve extensão, Lévi-Strauss enfatiza um tema relativamente desvalido no primeiro estudo: a questão do enigma.

Ao tratar da questão da análise dos mitos, o antropólogo inicia uma narrativa de um mito ameríndio, iroquês, muito semelhante ao mito de Édipo. Para que os correlatos pudessem se adensar, faz-se necessário identificar a posição do episódio da esfinge. Aqui ele recorre uma consideração de Boas sobre o papel dos enigmas na América do norte: tantos os enigmas, como os provérbios e adivinhações são gêneros praticamente ausentes em sua mitologia. Mas há duas exceções: quando insinuam nascimentos frutos de comércios incestuosos e quando são veiculados por uma feiticeira-coruja. Estas duas vias de inscrição do enigma na mitologia norte-americana são lidas como análogas ao dupla configuração na trama de Édipo (LÉVI-STRAUSS, 1960, p.65).

O antropólogo parte então para a definição de enigma como "uma questão sobre a qual se postula que não tem resposta", cujas transformações do enunciado, podem levar ao seu inverso, uma "resposta para a qual não há perguntas" (Ibidem), ou seja, um enigma denota uma "questão formulada de tal modo que a resposta não pode

\footnotetext{
${ }^{20}$ Para um estudo detalhado das relações entre as lendas coríntias e as tebanas, remeto o leitor ao próprio estudo de Vernant $O$ tirano coxo: de Édipo a Periandro (1981).
} 
chegar a atingi-lo, não consiga encontra-lo" (VERNANT, 1981, p.180). Então continua Lévi-Strauss:

Entre povos que separam história, geografia, língua e cultura, a mesma correlação entre enigma e incesto parece, pois, existir [...] Entre a solução do enigma e o incesto, existe uma relação, não externa e de fato, mas interna e de razão, e é por isso que civilizações tão diferentes como as da antiguidade clássica, e da América indígena, podem, independentemente, associá-los. Como o enigma resolvido, incesto aproxima termos destinados a ficar separados: o filho se une à mãe, o irmão à irmã, assim como o faz a resposta, conseguindo, contra toda expectativa, encontrar sua pergunta. (LÉVI-STRAUSS, 1960, p.67).

Um enigma, portanto, expressa um registro da linguagem marcado por uma impossibilidade de expressão. Ao tomar a metáfora comunicativa, Vernant representa-o como índice de um defeito estrutural da tentativa de intercâmbio verbal, de comunicação: "como se entre dois interlocutores, o primeiro fizesse uma pergunta a que apenas pudesse responder o silêncio do segundo" (VERNANT, 1981, p.181).

Ao deslocar a perspectiva de análise para a dimensão central do enigma na trama edípica, assim como sua relação com a temática do incesto, Lévi-Strauss permite uma nova leitura de Édipo. Édipo seria o herói que rompeu as barreiras da comunicação, da partilha social da linguagem, em suma, do pacto social, tanto ao encontrar a resposta para o enigma, quanto pelos atos exagerados para com seu pai e mãe.

Três pontos merecem ser destacados deste percurso realizado até o momento:

(1) Observamos pelas críticas de Carroll e Vernant dois pontos fundamentais: o primeiro é que na tentativa de reunir pacotes de relações presentes nas narrativas sobre os Labdácidas, Lévi-Strauss acabou por agrupar predicados distintos sob o mesmo mitema, ou seja, a unidade pretendida pelo antropólogo possui um baixo grau de consistência. O segundo ponto é o de que a interpretação do mito edipiano apenas se sustenta mediante o cruzamento com a mitologia ameríndia e suas representações basais. 
Da aproximação entre esses dois pontos, poderíamos concluir, a título de hipótese, que a interpretação essencial efetuada por Lévi-Strauss é sobretudo acerca da narrativa de Édipo. Eis os fatos que concorrem para isso: (a) não à toa, Lévi-Strauss nomeia todo o conjunto de mitos tebanos da linhagem dos Labdácidas, como mito de Édipo. A força desta nomeação não deveria ser menosprezada; (b) se retomarmos o conjunto dos mitemas a partir das proposições levantadas pelo antropólogo, assim como seu esforço para alterar certas passagens míticas, como no caso da esfinge, teremos que eles se encaixam antes à narrativa de Édipo que à de Cadmo ou de Antígona.

Esta constatação, ressalto, não levaria à consideração da análise de Édipo como uma interpretação de uma narrativa única, de vez que sua pluralidade estaria assegurada no cotejamento e correlação com a próprias narrativas gregas, que em certos pontos formam um conjunto - como a ênfase posta por Lévi-Strauss no caráter coxo, assinalada por Vernant - e com as narrativas ameríndias, as quais o antropólogo não deixa de aproximar o mito tebano. Portanto, a partir de nossa leitura, a análise de LéviStrauss, mesmo focando no valor exemplar de uma narrativa, resguardaria sua estrutura múltipla, transgressora de limites geográficos e históricos.

(2) É digno de nota o fato de que a análise de Édipo, escolhida para inaugurar a demonstração da aplicabilidade de seu modelo, produza uma contradição em seus termos. Desde a origem, temos em Lévi-Strauss e em seus postulados sobre a lógica mítica um problema: como vimos, sua definição da partícula mínima do mito, detinhase a fragmentos de história, predicados que marcavam a relação entre personagens. $\mathrm{O}$ caráter supralinguístico, que justificaria a recorrência de mitos tão próximos surgidos em contextos tão distintos, seria uma das principais premissas para a consecução de uma análise estrutural do mito. Em outros termos, o valor zero da fórmula Traduttore, Tradittore, permitiria ao mitólogo estabelecer uma compreensão da estrutura mítica para além das considerações linguísticas. Nas palavras de Lévi-Strauss: "O valor do mito permanece por pior que seja a tradução. [...] A substância do mito não se encontra nem no estilo, nem no modo de narração, nem na sintaxe, mas na história que nele é contada" (LÉVI-STRAUSS, 1955, p.225). Entretanto, não é o que acontece no caso da análise de Édipo.

Como vimos, um dos pontos altos das conclusões lévi-straussianas está na articulação do quarto mitema - que expressa a dupla torção característica da estrutura 
mítica - com os significados comuns dos nomes próprios da linhagem dos tiranos tebanos. A explicitação de tal fato foi celebrada por helenistas, como Jean-Pierre Vernant, como um dado importante dado a ter sua significação extraída de contextos alheios à lógica ameríndia, como uma "resposta à procura de sua questão". Ora, se tal passo foi fundamental tanto nas conclusões do antropólogo, quanto nas derivações propostas pelos seus sucessores, poderíamos dizer que Lévi-Strauss teria chegado à mesma sem o conhecimento prévio da semântica do grego antigo? Qual poderia ter sido o destino de sua análise se a tivesse levado a cabo, a exemplo da leitura de uma série de mitos ameríndios, sem conhecimento aprofundado da língua na qual emergiu?

(3) Por fim, destaco que o deslocamento de perspectiva efetuado pela releitura de Lévi-Strauss na Aula Inaugural, em que o papel do enigma passa ao primeiro plano da estrutura do mito de Édipo, inscreve a questão fundadora do mito no cerne da própria narrativa. Ou seja, ao invés de fazer da questão central do mito uma derivação externa à narrativa, ele acentua o papel central do enigma colocado pela esfinge, assim como os oráculos proferidos ao longo do enredo.

Como vimos, a estrutura mítica procede de um postulado universal: todo mito se configura como uma tentativa de dar equacionar uma questão constitutiva, dada a impossibilidade de resposta unívoca efetiva. Ao retomar o papel do enigma como central na trama edipiana, Lévi-Strauss parece apontar para via distinta de análise sobre este mito. Encontramos aí, um circuito narrativo marcado no seu âmago pela reunião de dois opostos homólogos, a saber, de uma pergunta sem resposta, o enigma, com uma resposta sem pergunta, o incesto enTabulado por Édipo. Esta via se aproxima de uma das primeiras análises de Édipo, na Poética de Aristóteles, na qual encontramos a afirmação de que Édipo - considerada por ele "a maior tragédia do teatro grego" (VIEIRA, 2009, p.17) - sustentaria na estrutura interna de seu mito "a mais bela de todas as formas de reconhecimento, de passagem ignorar ao conhecer, que é aquele que se dá juntamente com a peripécia, ou seja, a mutação dos sucessos no contrário" (ARISTÓTELES, 1973, p.452).

Por estas razões, poderíamos considerar que o mito de Édipo teria um valor especial justamente por responder em sua história à transgressão própria de todo mito, à tentativa de responder a uma pergunta impossível. E tal resposta, que buscarei mostrar doravante, se encontra, como bem apontou Lévi-Strauss, na própria nomeação de Édipo. 
Diante do enigma da esfinge, Édipo não responde apenas com o universal dos homens, com o sentido próprio de suas palavras, mas responde com seu nome próprio.

Como aponta Lévi-Strauss, Édipo é aquele que encontrou a resposta para uma questão que por essência não deveria ter resposta, aquele que decifrou o enigma da Esfinge, cujas maldições que afligiam Tebas. E disso se gaba, como podemos ver na seguinte passagem da discussão que inicia com Tirésias, o profeta cego da cidade:

Por que negaste auxílio ao povo quando

vivia a Esfinge, cadela de rapsódias?

Não de um desavisado a solução

do enigma dependia, mas de um profeta.

Ficou patente: nem as aves, nem

os deuses te inspiravam. E eu cheguei;

dei cabo dela, alguém que nada sabe, Édipo

vali-me do pensar e não dos pássaros. (SÓFOCLES,

Versos 391-398).

Reconhecido pela sua habilidade de resolver charadas, Édipo recebe entre tantas alcunhas, a de "o decifrador de enigmas". Como vimos, ele crê ter vencido a esfinge pelo uso de seu pensamento, pelo raciocínio envolvido em sua resposta. Entretanto, ela pode ser mais reveladora do que considera. Diante da Esfinge, ele ouve a seguinte questão, aqui retirada da versão das Fenícias de Eurípedes: "Há na terra um ser com dois, quatro, três pés, cuja voz é única. Apenas muda sua natureza entre os que se movem no chão, no ar e no mar. Mas, quando anda se apoiando sobre mais pés, é então que seus membros tem menos vigor" (EURÍPEDES apud VERNANT, 1981, p.186).

Sua resposta, como conhecemos tradicionalmente, é categórica: este ser é o homem. O homem que permanece o mesmo a despeito das modificações de sua forma de caminhar ao longo do tempo, engatinhando quando criança, de forma ereta quando maduro, e com uma bengala ou um cajado ao envelhecer. No comentário de Vernant, tal referência implica uma mensagem exemplar sobre o laço social importante:

O homem conhece estes três estatutos diferentes de existência, três idades: criança, adulto, velho. Deve percorrê-las em sequencia, cada uma a seu tempo, porque cada uma implica um estatuto social particular, uma transformação de sua própria 
posição e de seu papel no grupo. A condição humana estabelece uma ordem no tempo, porque a sucessão das idades, na vida de cada individuo, deve se articular na sequência das gerações, respeitá-la para harmonizar-se com ela, sob pena de retorno ao caos. (VERNANT, 1981, p.186)

Entretanto, diversos comentadores enfatizam o equívoco de sua resposta, ou ao menos, a perda de seu valor quando descontextualizada de seu campo linguístico originário. Como aponta Quinet, o enigma da esfinge, enigma central da trama, trata acima de tudo da "origem (do ser e da história) e do (não) lugar que lhe havia sido predestinado". Então continua:

Podemos mostrar como o nome de Édipo (Óidipous) pode ser escutado no enigma da Esfinge - "o que é que tem quatro pés (tetrapous), dois pés (dipous) e três pés (tripous)". [...] A Esfinge faz uma charada a partir da equivocidade significante. Mas Édipo só escuta o significado e julga ter acertado o enigma da Esfinge ao responder "o homem”. Não ouviu o principal: a Esfinge falava dele, pois é ele o ser de "pé inchado". (QUINET, 2009b, p.187).

Ao trabalhar com o texto original, Quinet levanta a possibilidade de se considerar as ressonâncias próprias do significante, como esta partícula "pous" que ressoa da enunciação do enigma pela esfinge.

Entretanto, um outro dado mostra como a resposta de Édipo, por mais que inexata pela dimensão do sentido, também foi pluralmente condicionada por tal materialidade sonora do significante: se no enigma encontramos a insistência da partícula significante pous, indicando a identidade do herói candidato a derrotar a "cadela cantora", o mesmo podemos dizer de sua resposta. Neste ponto da trama, encontramos Édipo não enunciando à Esfinge literalmente o termo "homem", humano (anthropos), mas sim, oi-dipous, que ipsis litteris pode ser traduzido como "os de dois pés" (VIEIRA, 2009, p.29), outro modo de se remeter aos homens.

Édipo, portanto, decifra o enigma, no entanto, como em toda trama, desconhecendo os fatores que subsistiam por detrás de tal feito. A sonoridade que 
decola de sua resposta, traz a marca deste dizer que extrapola os limites da linguagem, deste significante que somente pela via mítica encontra sua expressão. Vernant, por sua vez, busca uma significação no ideário grego para tal episódio:

Édipo, Oidípous, decifra o enigma; ele próprio é o dípous, o homem de dois pés. Mas seu erro, ou melhor, a maldição que pesa sobre sua linhagem coxa faz com que, ao decifrar o enigma, reunindo a resposta e a pergunta, ele encontre também seu próprio lugar de origem no trono de seu pai, na cama de sua mãe. Em vez de torna-lo semelhante ao homem que avança na vida caminhando ereto na sucessão de uma linhagem, seu sucesso identifica-o com esse monstro que as palavras da Esfinge evocam: o ser que tem, ao mesmo tempo e na mesma ocasião, dois, três, quatro pés, o homem que na progressão de sua idade não respeita, mas embaralha e confunde a ordem, social e cósmica, das gerações. (VERNANT, 1981, p.187)

Podemos, como Vernant e outros tantos comentadores, nos deter sobre a multiplicidade de significados extraíveis do termo Édipo. Oidípous, na tradução mais imediata pode ser lido como "pés inchados", atributo chancelado pela narrativa. Entretanto, como salienta Trajano Vieira (2009), encontramos diversas outras jogos significantes para o nome de Édipo na tragédia sofocliana: em oi-dípous, temos a remissão à universalidade dos homens, aos "de dois pés"; No trecho em que citamos, encontra-se "aquele que nada sabe, Édipo" - no original aparece como um joguete sonoro, "ho mêden eidos Oidípous" - cujo termo eidos, "aquele que sabe", particípio de Oida, repercute em Oidípous. Édipo por essa versão seria aquele que sabe pelos pés; sobre outro trecho, do mensageiro recém chegado a tebas, nos fala Vieira:

Pou e seu correlato hopou significam "onde", sentido para o qual convergem as questões formulados pelo mensageiro: o verbo katoish' é uma forma de kata-oida (“saber") que, como observei, associa-se a Oidi-pous. "Saber onde" é uma interrogação ironicamente formulada a respeito de um personagem que ocupa posição incerta no espaço. [...] Como fizera anteriormente, ao chegar em Tebas, o mensageiro reafirma 
nas entrelinhas (ou entreletras) os descaminhos que desgovernam a vida de Édipo: ouk oid'hodous ("não sei os caminhos") (VIEIRA, 2009, p.28)

Se, por um lado, podemos trabalhar nessa via de determinar a quais conjuntos de significado remeteria Édipo, por outro, temos a leitura propiciada pelas nossas construções precedentes: Édipo, mais que definido por um traço único, recebe seu valor pela não univocidade nem de sua enunciação, nem de sua significação. Em verdade, lido na chave lévi-straussiana, portanto, no interior de um mito que expressa o encontro impossível de uma pergunta sem resposta com uma resposta sem pergunta, o nome Édipo resguardaria uma dimensão do sem sentido do significante, de valor estruturante para uma cadeia, ou para o conjunto de narrativas.

Portanto, a partir dessa análise do mito de Édipo, podemos rever o postulado de Lévi-Strauss de que um mito “decola de seu fundamento linguístico”(LÉVI-STRAUSS, 1955, p.225) para aterrissar no campo diferencial de suas significações: se o voo do pensamento mítico permite concebe-lo por sua recorrência a despeito da distância geográfica e histórica, não podemos deixar de entrever como a cada voo, faz-se uma escala nas ressonâncias propiciadas pela equivocidade do significante de uma dada língua. Em outros termos, uma característica fundamental do mito é a de que aquilo que se descola do discurso corrente, quotidiano, não se apresenta somente como um sistema de posições diferenciais, mas também como tropeços e assonâncias da língua. $\mathrm{O}$ mito aponta, portanto, para uma cadeia fundada não apenas no valor discreto do significante, mas também em sua materialidade sonora. Eis o contexto da crítica lacaniana à leitura de Lévi-Strauss sobre os mitos, que, como veremos, crítica o fato de que a instância da letra no inconsciente seria apagada em prol de um pretenso sistema lógico abstraído de qualquer singularidade em seu conjunto.

Oidípous, em nossa hipótese, responderia à dupla determinação impressa pela modelo de transformação mítica de Lévi-Strauss relido através dos postulados psicanalíticos acerca das características do que seria um significante impossível. Por um lado, Oidípous realizaria a função de enodar toda a série mítica a partir de sua significação ligada ao andar coxo, próprio dos tiranos, segundo o pensamento grego, mas por outro Oidípous, seria a partícula significante que, ao responder um enigma insolúvel, inscreveria o lugar impossível de Édipo em sua trama. Portanto, Oidipous 
traria em seu cerne, a marca de sua determinação simbólica indissociada do real que sustenta seu lugar.

Vejamos a partir de agora, o modulações da leitura lacaniana sobre o mito, desde seu contato com Lévi-Strauss, enquanto modelo de formalização do discurso, até sua posição fundamental para a leitura da constituição subjetiva.

Se esta hipótese, que buscarei tratar em seus detalhes à frente, se sustentar, não poderíamos pensar em uma forma de subjetividade que mesmo determinada por uma lógica significante, escape da simples oposição entre um conceito de sujeito universal, pleno de significados e simbolismos, e um conceito de sujeito prescindido, mero reflexo de determinantes estruturais e inconscientes? A resposta a tal questão nos recolocaria as condições de possibilidades para emergência de um mito, assim como sua função global. 


\section{CAPÍTULO 4}

A psicanálise pós-freudiana encontra em Jacques Lacan, não apenas um incansável esforço de releitura crítica e justa contextualização da obra e dos conceitos freudianos, como um suspiro de inventividade e renovação dos modelos fundamentais de formalização da clínica, com seus reflexos tanto no entendimento e condução da experiência analítica, quanto na importância central que este dá ao intenso diálogo da psicanálise com as demais ciências, dentre as quais destacamos, apenas para citar algumas: a linguística, teoria dos jogos, teoria dos grupos, filosofia, politica, lógica, literatura, física e antropologia - interlocutora privilegiada de nossa empreitada, campo no qual Lacan encontra, na figura de Lévi-Strauss, tanto um sistema de pensamento com o qual realiza constantes trocas, como um amigo pessoal.

Vimos até o momento, como desde Freud a referência à categoria de mito aparece em uma posição central no diálogo entre a psicanálise e a antropologia, culminando não apenas na elevação do mito de Édipo a um estatuto seminal do seu entendimento da constituição subjetiva, como na realização daquela que pode ser considerada a mais polêmica e contestada obra freudiana para os parâmetros dessa troca, a saber, Totem e Tabu. A partir daí percorremos sua recepção no cenário etnológico da primeira metade do século XX, na tentativa de demonstrar como a referência mítica caminhava em conjunto com os destinos dados à psicanálise enquanto potencial interlocutora. Deste percurso chegamos a Lévi-Strauss que, na segunda geração de antropólogos pós-Totem e Tabu, não apenas sintetiza em sua obra as principais postulados da produção que lhe antecedera, como estabelece com a psicanálise uma troca sem precedentes, cujas repercussões serão centrais para a revolução na obra de Lacan a partir dos anos 50. O mito desponta em seu projeto como um campo privilegiado de análise, a partir da qual grandes avanços são realizados no que concerne à formalização da noção de estrutura.

Neste capítulo percorreremos, em linhas gerais, a via das incidências da noção de mito na obra de Jacques Lacan. Tal empreitada iniciará, primeiramente, com o estabelecimento das bases de influência da antropologia estrutural no projeto de pensamento lacaniano, passando desde a conferência $O$ mito individual do neurótico, "princípio de uma referência estruturalista como forma" (LACAN, 1966, p.76), até o 
conjunto da sua obra. O objetivo principal é mostrar como a importação lacaniana da formalização dos mitos operada por Lévi-Strauss, marca decisivamente não somente as particularidades da leitura do papel da ordem simbólica na experiência analítica, como grande porção de seu projeto de formalização. Por fim, daremos as coordenadas do que poderia ser o ponto de contribuição da psicanálise de Lacan ao método de interpretação do mito pela antropologia de extração lévi-straussiana.

\section{A psicanálise de Lacan e a influência de Lévi-Strauss em seu projeto de "retorno} a Freud"

O papel da antropologia lévi-straussiana no projeto de releitura das bases da experiência clínica psicanalítica, tal qual levado a cabo por Lacan no início dos anos 50, foi largamente desenvolvido desde seu princípio tanto pelo próprio Lacan, como por comentadores de sua obra. Entre os últimos, encontramos uma pluralidade de posições sobre o grau de influência do antropólogo. Dentre os comentadores mais comedidos, estão os que argumentam que sua maior contribuição teria sido trazer a linguística estrutural a Lacan, a este respeito tomemos o comentário de Elizabeth Roudinesco: "Sua verdadeira apropriação do sistema saussuriano, quer dizer, dos princípios da linguística estrutural, data do encontro com a obra de Claude Lévi-Strauss" (ROUDINESCO, 2005, p.304).

Outros comentadores, mais afeitos ao projeto do antropólogo, tratam a obra de Lévi-Strauss como a produção de uma antropologia há muito esperada por Lacan, que reestruturaria sua posição frente à possibilidade de formalização da clínica psicanalítica. Em outras palavras, tal antropologia teria explicitado a possibilidade de se pensar uma ordem globalizante de determinação da subjetividade que isentaria suas considerações ao apelo a uma instância psíquica autônoma, possibilidade esta requerida desde a tese de doutorado de Lacan, A Psicose Paranoica e suas Relações com a Personalidade, de 1932 (SIMANKE, 2002). Mais ainda. Poderíamos, aqui, acompanhar as considerações de Markos Zafiropoulos (2006) e atestar que subjacente às diversas dívidas - sempre manifestas - para com o antropólogo, está uma ainda mais fundamental: é do contato com o pensamento de Lévi-Strauss que Lacan encontrará um meio de (re)ler Freud, ou melhor, de confiar em suas palavras. No entanto, mesmo entre estas duas posições 
emblemáticas, ainda restam algumas delimitações sobre os pontos centrais nos quais se situam a apropriação lacaniana da antropologia de Lévi-Strauss.

Já em 1949, data em que o filósofo Alexandre Koyré apresenta pessoalmente Lévi-Strauss a Lacan, encontramos uma primeira menção ao antropólogo no escrito $O$ estádio do espelho como formador da função do eu, tal como nos é revelada a experiência psicanalítica, na qual Lacan se refere ao caráter explicitador das imagos fundamentais presente na "penumbra da eficácia simbólica" (LACAN, 1949, p.98). Se o psicanalista não desenvolve tal referência além desta breve menção, podemos já nos questionar se a escolha da metáfora da "penumbra" não seria um prenúncio deste registro da experiência que não se assimila à lógica imagética. De qualquer modo, a referência a Lévi-Strauss, será tímida, mesmo lateral, até o ano de 1953, quando Lacan finalmente responde à convocação do antropólogo àqueles que se "dedicavam às ciências sociais, de extrair do método estrutural todas as consequências lógicas para seu campo" (LÉVI-STRAUSS, 1945, p.46).

De forma sintética, pode-se dizer que, até o início da década de 50, o esquema do estádio do espelho, ao lado da dialética hegeliana e da teoria do tempo lógico, foi considerado um dos principais modelos para a apreensão da lógica da constituição subjetiva, fundamental para a leitura da experiência analítica. Em seus termos:

O estádio do espelho é um fenômeno ao qual atribuo um duplo valor. Em primeiro lugar, tem um valor histórico por marcar um ponto de virada decisivo no desenvolvimento mental da criança. Em segundo lugar, ele tipifica uma relação libidinal essencial com o corpo-imagem. (LACAN, 1951, p.14).

O estádio do espelho descreve a formação do Eu como proveniente de um processo de identificação com a imagem de um outro. A universalidade pretendida por Lacan, para alicerçar esse modelo ao estatuto de uma antropologia, estaria na insuficiência neurofisiológica constitutiva do bebê humano. O estádio do espelho em seu duplo valor - estrutural e histórico, pode-se dizer - posiciona a formação do Eu, como resultante da primeira experiência de integração corporal vivida pela criança, com profundas consequências para as demais funções do bebê humano e que servirá de modelo para suas relações libidinais ulteriores. O grande postulado aqui é o de que a síntese da experiência corpórea, viria a partir da integração de uma imagem totalizante 
de si, articulada desde um outro, que fundaria as bases da noção de Eu e da dimensão do reconhecimento da realidade socialmente partilhada. Esse modelo do registro imaginário da experiência foi essencial para ressituar a psicanálise frente ao fenômeno da loucura, da alienação e alteridade do $\mathrm{Eu}$, da verdade em oposição ao simplismo da noção de realidade, assim como retomar os termos da técnica analítica, acerca da dinâmica da transferência e da interpretação.

Entretanto, uma série de problemas ficam de fora de seus parâmetros: como a sistematização da noção de inconsciente, categorizada nesse momento por Lacan como uma "noção inerte e impensável" (LACAN, 1946, p.183); a noção de contratransferência, como fruto de mal-entendidos por não propiciar uma base de leitura isenta de ilusões e enganos, próprios ao registro imaginário (LACAN, 1953, p.244) ${ }^{21}$; as resistências em análise, resultante da agressividade própria ao imaginário, cuja solução dificilmente se colocava em seus próprios termos (Ibidem, p.243); os elementos discursivos em que se passa um tratamento operado pela linguagem, que excederia seu aspecto projetivamente intencional (LACAN, 1936, p.87), além de inúmeros conceitos freudianos que não se encaixavam nem no modelo, nem a experiência por ele propiciada, como a noção de complexo de Édipo, de desejo, o papel do pai aí desempenhado, assim como nosso tema, a noção de mito em sua efetividade simbólica.

Devemos ressaltar, neste contexto, que desde sua tese de doutorado a busca por modelos antropológicos já se fazia presente. A busca de Lacan por uma apreensão global dos fatos psíquicos que fuja do recurso naturalizante dos termos da psicologia de sua época, posiciona a antropologia e a teoria social como um importante interlocutor. No interior desta procura, Lacan depara-se primeiramente com a obra de Lévy-Bruhl. A problemática colocada pela tese de 32 da relação entre ideal e real, entre apreensão da realidade e sua interpretação - que culminará no postulado de que todo conhecimento tem um estatuto paranoico - encontrará em Lévy-Bruhl a concepção da relatividade de modos de conhecimento. A mentalidade primitiva, tal qual postulada pelo antropólogo,

${ }^{21} \mathrm{~A}$ crítica realizada por Lacan ao anti-historicismo da ego-psychology e à falta de consideração da dimensão simbólica pela vertente da psicanálise que enfatizava a relação de objeto como modelo para todas as relações do analisando com o analista, encontra aqui seus termos e pode ser resumida da seguinte forma: "A importância das 'relações de objeto' como uma descrição do que ocorre entre a mãe e a criança, e então entre analista e analisando, encontra uma falha em reconhecer esse terceiro elemento, o registro simbólico: 'De fato, esse registro desaparece completamente na relação de objeto, e pelo mesmo ponto o registro imaginário também (Lacan, 206). Nesta via, o analista (e aqui Balint era o principal alvo de Lacan) era enredado em uma relação dual, e negando a isso" (PARKER, 2011, p.129). 
teria uma lógica própria de regulação e articulação do conhecimento, produzindo um modelo distinto do encontrado na sociedade ocidental. A representação coletiva proposta por Lévy-Bruhl, de origens comteanas e durkheimianas (Cf. SIMANKE, 2002, p.347), estabeleceria um modo global pela qual os indivíduos de uma determinada sociedade responderiam em suas instituições. Se, por um lado, esta noção auxiliava Lacan a defender o fenômeno da loucura, a partir de uma matriz que não respondia a uma representação coletiva hegemônica, por outro, permitia pensar em termos totalizantes um modo objetivizante de apreensão da realidade social e seus efeitos determinantes sobre a interpretação de cada agente aí inserido.

Entretanto, as críticas à influência de uma ideologia evolucionista no pensamento intelectualista de Lévy-Bruhl, bem caracterizada pelo viés eurocêntrico de sua terminologia, não ficaram indiferentes a Lacan e serão revistos por uma dupla referência: de uma lado, Mauss e a sociologia fundada pela apreensão total dos fatos sociais, e de outro, na versão antropológica da filosofia hegeliana, tal qual realizada por Alexander Kojève. Com Mauss, Lacan encontra o início da produção de uma antropologia que retira o viés psicologizante das representações coletivas, no mesmo movimento em que desfaz a hierarquia entre pensamento primitivo e civilizado. Como vimos, em Ensaio sobre a dádiva (1924), Mauss articula a dimensão da troca por uma matriz correlata à totalidade das instituições da sociedade. Nos termos de Lacan, a obra de Mauss representaria a explicitação de que "as estruturas da sociedade são simbólicas" (LACAN, 1950, p.134). Mas a lógica simbólica da troca - essencial para a concepção de um sistema autônomo frente os agentes sociais que os encarnam, tal qual revista por Lévi-Strauss - não fora explicitamente declarada por Mauss. A apreensão totalizante de Mauss ainda apresentava uma necessidade de recurso à empiria que se caracterizava como um obstáculo ao alcance de seus postulados tanto para a formalização de um projeto epistêmico, quanto para a leitura da relação entre individuo e sociedade isenta de referenciais psicológicos.

A partir de Kojève, Lacan realizará uma revisão na sua teoria do sujeito, sua constituição e gênese, fora de uma perspectiva psicológica, tão presentes em seus postulados sobre o imaginário. No comentário de Simanke:

Lévy-Bruhl permitiria a Lacan situar geneticamente os processos cognitivos e, deste modo, dispor de um instrumento 
para pensar a diferença entre o conhecimento paranoico e o dito normal em termos de uma localização diferenciada ao longo de uma mesma linha evolutiva. Já com Kojève, todo esse processo vai poder ser visto, não da perspectiva da instância determinante (a sociedade), mas no da instância a ser determinada (o sujeito), com a vantagem suplementar de evitar os escolhos de um excesso de psicologismo (SIMANKE, 2002, p.398)

Ora, Kojève, como veremos adiante, por esta via, abriria a possibilidade de um modelo de antropologia, ainda que oriundo de uma perspectiva filosófica, na qual Lacan pudesse fundar uma relação entre sujeito e o socius de maneira a sustentar a tensão inerente a tal relação, sem que um necessite ser reduzido à lógica do outro. É neste cenário que Lacan se encontra com a antropologia lévi-straussiana: de um lado, temos modelo do estádio do espelho que deixava a desejar na sustentação de uma matriz sincrônica de compreensão da subjetividade, além de não responder a uma série de questões de uma prática clínica pautada na linguagem, como mencionado acima; e de outro, uma leitura do sujeito de extração kojèveana, que demandava tanto uma teoria que abarcasse a diferença, a negatividade-negadora - portanto, além do modelo especular - quanto uma teoria social que realizasse o papel determinante de uma ordem de determinação extra-subjetiva, com a qual tal sujeito possa ser conjugado.

No início dos anos 50, este cenário, como dissemos, começa a tomar outras configurações Em uma crítica à inércia da psicanálise pós-freudiana, consequência de sua cada vez mais sombria articulação entre teoria e prática, em especial sua desconsideração pela função da fala (LACAN, 1953b, p.246), Lacan salienta o valor conceitual da antropologia estrutural para a formalização da teoria analítica nos seguintes termos:

Quanto a nós, pensamos que, se inovamos, não é de nosso gosto fazer disso um mérito. [...] Numa disciplina que só deve seu valor cientifico aos conceitos teóricos que Freud forjou no progresso de sua experiência, mas os quais, por serem ainda mal criticados, e por isso conservarem a ambiguidade da língua vulgar, beneficiam-se dessas ressonâncias, não sem incorrer em mal-entendidos, parecer-nos-ia prematuro romper a tradição de 
sua terminologia. [...] Mas, parece-nos que esses termos só podem esclarecer-se ao estabelecermos sua equivalência com a linguagem atual da antropologia ou com os mais recentes problemas da filosofia, onde, muitas vezes, a psicanálise só tem a se beneficiar. (LACAN, 1953b, p.241-2).

Esta citação, extraída de Função e campo da fala e da linguagem (1953b), já explicita um Lacan plenamente envolvido em seu projeto de reformulação das bases conceituais para a experiência psicanalítica, por ele denominado, o retorno a Freud. Retorno não apenas ao urgente estudo da "história de seus conceitos e à reflexão sobre seus fundamentos subjetivos" (Ibidem), mas empreendimento que visa demonstrar que "esses conceitos só adquirem pleno sentido ao se orientarem num campo de linguagem, ao se ordenarem na função da fala" (Ibidem, p.247). O sentido do retorno a Freud, portanto, procede de um primeiro reconhecimento, de que "quer se pretenda agente de cura, de formação ou de sondagem, a psicanálise dispõe de apenas um meio: a fala do paciente" (Ibidem, p.248b), ou seja, de que a "psicanálise deve ser a ciência da linguagem habitada pelo sujeito, linguagem onde este está aprisionado e torturado" (LACAN, S.III, p.276); e de um consequente encaminhamento de método, de busca por modelos de formalização desta incidência da linguagem, que aí desempenhem um papel de auxílio à teoria e técnicas analíticas. Eis a posição em que a linguística e a antropologia estrutural de Lévi-Strauss encontram o pensamento de Lacan, ou, nas palavras deste:

A psicanálise desempenhou um papel na direção da subjetividade moderna, e não pode sustentá-lo sem ordená-lo pelo movimento que na ciência o elucida. É esse o problema dos fundamentos que devem assegurar a nossa disciplina seu lugar nas ciências: problema de formalização, na verdade muito mal introduzido. [...] Objetivação abstrata de nossa experiência em princípios fictícios ou simulados do método experimental: aí encontramos o efeito de preconceitos cujo campo, antes de mais nada seria preciso limpar, se quisermos cultivá-lo segundo sua estrutura autêntica. [...] Praticantes da função simbólica, é espantoso que nos esquivemos de aprofundá-la, a ponto de 
desconhecer que é ela que nos situa no cerne o movimento que instaura uma nova ordem das ciências, com um novo questionamento da antropologia. (LACAN, 1953b, p.285-6) ${ }^{22}$

A antropologia a que neste ponto se refere Lacan, em sua acepção ampla, é aquela que, sustentando a função simbólica em seu cerne, fundamenta as ciências conjeturais do século $\mathrm{XX}$, cuja vanguarda se encontra no projeto formal de matematização da linguagem empreendido pela linguística estrutural. A tal ponto que desta podemos extrair o procedimento lógico próprio ao simbólico. Em suas razões:

A forma de matematização em que se inscreve a descoberta do fonema, como função dos pares de oposição compostos pelos menores elementos discriminativos captáveis da semântica, leva-nos aos próprios fundamentos nos quais a doutrina final de Freud aponta, numa conotação vocálica da presença e da ausência, as origens subjetivas da função simbólica. E a redução de todas as línguas ao grupo de um número pequeníssimo dessas oposições fonêmicas, dando início a uma formalização igualmente rigorosa de seus mais elevados morfemas, coloca a nosso alcance uma abordagem estrita de nosso campo. (Ibidem, p. 286).

Por esta via, a sistematização fonêmica, tal qual abstraída pela análise linguística, aponta para a noção linguagem como uma estrutura fundada pela lógica de oposições, central para tanto revalorar o estatuto da experiência em geral, e da experiência analítica, em específico, quanto para o estabelecimento da teoria psicanalítica como uma ciência, posto que a linguística promove uma revisão epistemológica do estatuto de cientificidade no conjunto das ciências sociais, ditas humanas. Entretanto, continua Lacan neste trecho programático:

Cabe a nós, com ela [a linguística] nos aparelharmos para encontrar aí nossas incidências, como já faz, por estar numa linha paralela, a etnografia, decifrando os mitos segundo a

22 Conforme François Dosse: "Lévi-Strauss serve, pois, de modelo para a conquista da cientificidade do discurso psicanalítico, e Lacan inveja-lhe a simbiose que ele conseguiu realizar entre etnologia, linguística, matemática e psicanálise” (DOSSE, 1992, p.143). 
sincronia dos mitemas. [...] Não é patente que um Lévi-Strauss, ao sugerir a implicação das estruturas da linguagem e da parte das leis sociais que rege a aliança e o parentesco, já vai conquistando o terreno mesmo em que Freud assenta o inconsciente? Por conseguinte, é impossível não centrar numa teoria geral do símbolo uma nova classificação das ciências em que as ciências do homem retomem seu lugar central, na condição de ciências da subjetividade. (Ibidem, p.286-7).

Dois pontos devem ser ressaltados desta cita: em primeiro lugar, encontramos aí uma aproximação da obra do antropólogo, em especial, de As Estruturas Elementares, como situada no mesmo terreno em que Freud postulou seu conceito de inconsciente. Lévi-Strauss extrai das classificações de campo uma articulação de linguagem que torna as posições e papéis a serem encarnados pelos indivíduos, fundamentais para compreender, além dos sistemas de trocas, todo o conjunto de atitudes e comportamentos derivados das relações aí implicadas, mesmo que esta determinação não esteja à disposição por estes que os encarnam.

O segundo ponto a salientar, está na breve menção à análise de mitos como um procedimento de extração do conjunto das mais diversas narrativas, de uma sincronia de mitemas. Este trecho foi essencial, como dissemos, para trabalho anterior (DOMICIANO; DUNKER, 2010), no qual apresentamos um contraponto à interpretação de Elizabeth Roudinesco, sobre a pretensa derivação inovadora realizada por Lacan, em $O$ mito individual do neurótico, de um modelo de estrutura extraído das organizações dualistas, tal qual formalizado por Lévi-Strauss em $1952^{23}$. Se aqui Lacan, menciona a noção de mitema é justamente pelo contato com o seminário ministrado pelo antropólogo na École Pratique des Hautes Études desde 1952. Munidos desta visão, podemos melhor interpretar a franca manifestação de Lacan a Lévi-Strauss em 1956:

O relevo da coisa [(formalização de mitos)] é por mim altamente apreciado porque, como Lévi-Strauss não ignora, tentei quase de imediato e ouso dizer, com pleno sucesso,

\footnotetext{
${ }^{23}$ Em Roudinesco encontramos: "Assim, partindo das estruturas complexas, ele inventa uma estrutura quaternária, composta por nocoes já elaboradas antes da guerra, mas reatualizadas sob novas categorias”. (ROUDINESCO, 1994, p.294)
} 
aplicar sua grade aos sintomas da neurose obsessiva; especialmente à admirável análise que Freud fez no caso do Homem dos Ratos, e isso numa conferência que intitulei $O$ mito individual do neurótico (LACAN, 1956, p. 90 - grifo nosso).

A grade a que se refere o psicanalista, fundamental para a construção de sua conferência sobre o Homem dos Ratos pode aqui, portanto, ser ressituada como sendo aquela que Lévi-Strauss propôs a respeito da análise dos mitos, que será denominada, em A estrutura dos mitos (1955), como a fórmula canônica do mito. Retomando os dois pontos salientados anteriormente, não poderíamos aqui nos questionar quais consequências extrair deste fato para a compreensão dos processos de importação conceitual operados por Lacan? Ou melhor, não teríamos na análise dos mitos, mais do que a demonstração do procedimento efetivado no campo da antropologia, um modelo para as particularidades do que foi a leitura lacaniana do ideário estrutural? Seria o mito, por sua própria constituição e pelo modo como foi formalizado por Lévi-Strauss o primeiro modelo de linguagem em Lacan?

Uma primeira consequência, de caráter bibliográfico, certamente seria a reintrodução do texto $O$ mito individual do neurótico, entre os grandes textos da obra lacaniana. Por anos relegado a um caráter secundário - seja por questões políticas, seja pelo seu difícil acesso e leitura - nesta conferência, como veremos, Lacan dá as bases não somente do que será seu entendimento de mito, como de grande parte da lógica simbólica a ser posteriormente explicitada. Nesta via, o papel da referência ao mito poderia ser melhor situado em sua relevância tanto, em um espectro mais abrangente, para o conjunto da obra do psicanalista, quanto, em um nível restrito, para o projeto lacaniano de retorno a Freud. Sobre este ponto, Zafiropoulos nos diz:

O sentido do retorno à Freud é o de reintroduzir o mito no coração da experiência psicanalítica. O mito de Édipo, mas também e mais globalmente todo o que o psicanalista empresta da antropologia francesa especialmente de Lévi-Strauss, e reside na ordem simbólica que Lacan, como Lévi-Strauss, reserva ao princípio de estruturação das sociedades como ao princípio de estruturação do inconsciente. (ZAFIROPOULOS, 2004, p.1920) 
Passemos, agora, à explicitação da forma como a assimilação lacaniana do ideário estrutural esteve, desde seus primórdios, intimamente ligada à questão do mito e seu valor para a formalização da experiência psicanalítica. A partir deste ponto, trilharemos as facetas e funções do mito na obra de Lacan, ponto privilegiado do intercâmbio com a antropologia social, de modo a explorar algumas das possíveis contribuições do psicanalista à temática do mito, assim como suas formas de apropriação do mito para a concepção do que se pode conceber na clínica.

\section{O mito individual do neurótico: a categoria de mito como porta de entrada da}

\section{lógica simbólica}

Aos 4 de março de 1953, o Collège Philosophique, a convite de Jean Wahl, sediou a conferência $O$ mito individual do neurótico ou Poesia e verdade na neurose.". Seu título completo, poucas vezes mencionado, já traz a marca da importância da presença da lógica mítica no pensamento de Lacan. Se por um lado, à impossibilidade de unificação, de simples enunciação de seu nome, estatuto comum ao mito e à verdade, Lacan brinca com o desdobramento típico do pensamento mítico/neurótico; por outro, traz aí o plano geral de sua fala, que poderia bem ser descrito como uma tentativa de formalização tanto do mito individual produzido pelo neurótico obsessivo "paradigmático" na literatura psicanalítica, a saber, o Homem dos ratos, quanto do roteiro imaginário relatado por Goethe em sua autobiografia intitulada Poesia e Verdade. Mais ainda.

Através de um "comentário pesado e obscuro" (ROUDINESCO, 2005) destes textos, Lacan procura estabelecer as condições de possibilidade, dentro da racionalidade psicanalítica, por sua vez essencialmente ligada à noção de verdade, da assimilação de uma ordem globalizante de determinação cultural, portanto, pré-subjetiva, tal como postulada pela antropologia estrutural à época. Ao peculiar projeto de um pensamento que prima pela racionalidade, pelo conceito $^{24}$, sem perder de vista a irredutibilidade da categoria de sujeito (OGILVIE, 1993), que responde este escrito.

${ }^{24}$ Foucault em um texto dedicado à obra de Canguilhem, faz uma análise do quadro geral da filosofia francesa, conjugando as diversas linhas e atitudes presente em tal cenário, em uma oposição básica entre duas vertentes: encontraríamos lá, por um lado, uma filosofia da experiência, do sentido, do sujeito; por outro, uma filosofia do saber, da racionalidade, do conceito. O costume, então, era escolher entre um destes lados. (Cf. OGILVIE, 1991) 
Considerado seu trabalho de maior influência lévi-straussiana (SIMANKE, 2002), haja vista, e.g., a reformulação da consagrada tríade imaginária edípica para uma estrutura quaternária - o que tornaria patente, eis um "progresso tanto na técnica quanto na teoria sobre a neurose obsessiva" (LACAN, Carta a Lowenstein de 14-07-53 apud ZAFIROPOULOS, 2006, p.158), o desdobramento entre um pai imaginário e um simbólico, como já entrevisto no seminário sobre o Homem dos lobos (Seminário -1) $O$ mito individual traz desde seus primeiros instantes o reconhecimento dos limites de uma formalização pretensamente "cientificizante" do campo psicanalítico. Neste encontramos as seguintes razões:

A psicanálise talvez seja atualmente a única disciplina comparável às artes liberais, pelo que preserva dessa relação da medida do homem consigo mesmo - relação interna, fechada sobre si mesma, inesgotável, cíclica, que o uso da fala comporta por excelência. (LACAN, 1953a, p.9)

Por ser uma experiência locada no seio de seu único meio possível, a saber, a fala [parole], a psicanálise necessita, para tratar de si, recorrer a algo próximo de um mito que permite dê formulação discursiva a algo não objetivável. Sejamos mais claros. A fala é aqui concebida não como um mero flatus vocis, i.e., expressão vocálica límpida de um pensamento prévio, mas como um verbalizer (LACAN, 1953b, p.257) [verbalizar, autuar] que traz em sua constituição a emergência de uma verdade, em sua enunciação um posicionamento subjetivo daquele que fala. Não podendo falar objetivamente desta verdade, posto que é "na medida em que a fala progride que ela a constitui" (1953a, p.11), a psicanálise demanda de mitos. Importante aqui salientar que, em um movimento análogo ao encontrado no pensamento freudiano dos primórdios do estabelecimento da particularidade da experiência analítica, a relevância do fenômeno mítico para sua teoria acompanha uma maior consideração pelo fenômeno da palavra, da fala como portadora de uma realidade fundamental para a determinação da subjetividade.

No interior deste cenário, o recurso à aproximação da psicanálise com as artes liberais expressa a tensão presente na relação entre o projeto de formalização proposto pelo ideário estrutural e o posicionamento de resistência da psicanálise ao apagamento da referencia ao sujeito. Nos termos de Richard Simanke: 
Se Lacan concede em equiparar a psicanálise às artes liberais, naquilo que elas se distinguem das ciências objetivas que daí se originaram, seu objetivo é enfatizar o modo como se reflete no campo psicanalítico a revolução estruturalismo, e a especificidade desse reflexo pode ser pensada em termos da impossibilidade, no lado da psicanálise, de abrir mão de uma referência ao sujeito, que parece cada vez mais ociosa no interior de um paradigma estrutural (SIMANKE, 2002, p.478).

Neste momento, um dos mitos requeridos é aquele pelo qual Hegel, lido por Lacan através das lentes de Kojève, permite tratar da relação intersubjetiva. Entramos aqui num dos pontos centrais para a compreensão do posicionamento ímpar de Lacan na ratio estruturalista, a saber, a sustentação de uma teoria negativa do sujeito. Façamos um parêntese para explicitar este ponto.

\subsection{Entre um sujeito prescindido e um sujeito pré-cindido}

O pensamento estrutural, ao postular um sistema simbólico anônimo - préexistente a toda e qualquer subjetividade - que, como um a priori kantiano, seria condição de possibilidade de qualquer manifestação humana, encontra-se, cada vez mais, prescindindo da categoria de sujeito.

Este é definido, aqui, como "uma espécie de encruzilhada onde acontecem coisas. As encruzilhadas são puramente passivas; há algo que acontece nesse lugar. [...] não há opção: é questão de probabilidades." (LÉVI-STRAUSS, 1978, p.14). Ou ainda, como Michel Foucault (1966) nos coloca: “O 'sujeito' explodiu (vejam a literatura moderna). É a descoberta do 'há'. Há um '-se'” (FOUCAULT, 1966 apud OGILVIE, 1991, p.47). No lugar da referência a um sujeito, portanto, o pensamento estrutural valese essencialmente da categoria sociológica de indivíduo.

Se este posicionamento epistemológico nos liberta do postulado metafísico de uma subjetividade originária, autônoma, decerto deixa em aberto, como nos fala Ogilvie, "a questão da produção e da natureza de uma subjetividade sujeita" (OGILVIE, 1991, p.43). Em face deste problema, Lacan tratará da questão do sujeito de uma maneira nova. Através do recurso a Kojève, como vimos, poderá abordar os efeitos de 
uma ordem global de determinação pelo viés da instância determinada, em outros termos, do sujeito e sua gênese (Ibidem). A referência à negatividade, proveniente do pensamento de Hegel, enquanto noção central para entendermos a relação entre sujeito e estrutura, merece, aqui, certos esclarecimentos. Nas palavras de Simanke:

Em outras palavras, o assujeitamento do sujeito à linguagem que Lacan passa a propor assumiria, no limite, a forma de uma aniquilação do sujeito que a doutrina estruturalista implica. Mas, pela ferramenta teórica da dialética hegeliana, Kojève permite tentar uma abordagem do sujeito e de sua gênese fora de uma perspectiva psicológica. [...] Isso terá o mérito de oferecer a Lacan uma saída para, mesmo subscrevendo o anti-psicologismo generalizado do método estruturalista, manter o sujeito como um dos pilares de sua teoria, bastando, para tanto, traduzir uma vez mais os "tempos" da dialética nos termos de uma "lógica do significante" (SIMANKE, 2002, p.397).

A concepção de uma ordem de determinação totalizante do simbólico, condição de possibilidade, estrutura "no interior do qual tudo o que é humano tem de arranjar-se" (LACAN, S.II, p.44), provinda de um kantismo tornado concreto por LéviStrauss, não possui, por isso mesmo, espaço para um sujeito senão aquele que de um campo fenomenal transcende enquanto mero lócus de a prioris necessários à constituição deste campo $^{25}$. Não há aí uma negatividade que permita ir além da experiência possível. Algo bem distinto do postulado é colocado por Lacan. Através da antropogênese filosófica de Kojève, leitura de matiz existencialista da dialética da Consciência de si hegeliana, Lacan pode dar contornos à discordância "fundamental entre o Eu e o ser” (LACAN, 1946, p.188), resgatando, desta guisa, a função do sujeito enquanto "vinculada à verdade do desejo" (SAFATLE, 2005, p.46). Como é sabido, o desejo em Kojève é pura negatividade, em outros termos, juntamente com o trabalho e a linguagem, o desejo define-se como ato de negação do dado natural que permite a um sujeito tomar Consciência de si (SAFATLE, 2005, p.43), posto que o mundo natural é, por definição, hostil a um projeto humano. Ao trazer o enredo da relação mortal entre o

\footnotetext{
${ }^{25} \mathrm{Na}$ “Crítica da Razão Pura”, Kant apresenta desta maneira a noção de sujeito transcendental
} 
senhor e o escravo para caracterizar as origens da consciência, poderíamos dizer que Lacan encontra aí um dos primeiros recursos míticos em sua obra. Em seus termos:

A relação do senhor e do escravo é um exemplo-limite, por que é claro, o registro imaginário em que se desdobra só aparece no limite da nossa experiência. Hegel dá conta do laço inter-humano. Tem de responder não somente pela sociedade, mas pela história. Ora, há uma de suas faces essencais que não é nem a colaboração entre os homens, nem o pacto, nem o laço de amor, mas a luta e o trabalho. E é nesse aspecto que ele se centra para estruturar num mito original a relação fundamental, no plano que ele mesmo define como negativo, marcado pela negatividade (LACAN, S.I, p. 254)

A referência à dialética intersubjetiva, portanto, traz a possibilidade de se pensar um sujeito com um estatuto de transcendência distinto do previsto pelos padrões epistemológicos kantianos, de vez que, à diferença de um certo condicionante da experiência sensível, o sujeito aqui, primeiramente alienado num outro, toma consciência de si através de atos de negação, podendo-se dizer que sua transcendência é essencialmente negativa (SAFATLE, 2005, p.44). Em outros termos, esta transcendência seria não-constitutiva da experiência sensível, de vez que se definiria por um processo que não se expressa na dimensão imediata dos fenômenos, pois "não é de realidade que se trata, mas de verdade" (LACAN, 1953b, p.257). A um sujeito prescindido pela lógica estrutural interpõe-se um sujeito pré-cindido, desde sua constituição alienado num outro.

\subsection{O mito individual entre o simbólico, o imaginário e o real: eixos de leitura a uma teoria do mito em Lacan}

Voltemo-nos agora às facetas do mito tais quais possivelmente encontradas em O mito individual no do neurótico e à consideração de suas reverberações no interior da obra de Lacan. Caracterizaremos sumariamente tais facetas, para em seguida, tratá-las com maior detalhamento. 
Logo no início do escrito, como vimos, após caracterizar a psicanálise como próxima às artes liberais, no que estas mantém da relação do homem consigo mesmo, encontramos uma primeira definição de mito. Em suas palavras:

O mito é o que dá uma formulação discursiva a algo que não pode ser transmitido na definição da verdade, porque a definição da verdade só pode se apoiar sobre si mesma, e é na medida em que a fala progride que ela a constitui. A fala não pode apreender a si própria, nem apreender o movimento de acesso à verdade como uma verdade objetiva. Pode apenas exprimi-la - e isso de uma forma mítica. Daí aquilo em que a teoria concretiza a relação intersubjetiva, e que é o complexo de Édipo, tem valor de mito (LACAN, 1953a, p.13).

A partir desta citação podemos extrair duas facetas básicas da concepção de mito neste momento da obra de Lacan: (1) o primeiro seria constituir-se como modelo discursivo privilegiado, neste momento, para tratar da experiência psicanalítica de vez que há uma dimensão que escapa à simples tentativa de objetificação; (2) o segundo, seria notar como esse inapreensível, no presente escrito, ligado essencialmente à dimensão da verdade, faz com que o mito possua uma estrutura ficcional próxima à estrutura da verdade. A dimensão da verdade, assim como a do mito, só tem a possibilidade de se dizer ao se redizer, sempre mais uma vez, sempre falhando na tentativa de se asseverar uma última palavra plena. Ao incluir o complexo de Édipo nesta chave, Lacan dimensiona o papel central do estudo do mito para a teoria psicanalítica. Poucos parágrafos após a citação anterior, encontramos uma nova incidência da definição de mito.

Se nos fiarmos na definição do mito como certa representação objetivada de um epos ou de uma gesta que exprime de maneira imaginária as relações fundamentais características de certo modo de ser humano numa determinada época, se o entendermos como manifestação social latente ou patente, virtual ou realizada, plena ou esvaziada de seu sentido, desse modo do ser, então é certo que poderemos encontrar sua 
função na vivência mesma de um neurótico (LACAN, 1953a, p.15).

Nesta segunda investida de aproximação ao fenômeno mítico, encontramos outra díade de funções a ser desempenhada por ele: (1) o mito aparece como uma narrativa heroica, um epos objetivado na qual a saga do herói se liga às narrativas coletivas em que está inserido. A determinação do mito como uma forma discursiva que insere o sujeito em um certo momento histórico, já marca uma diferença com a noção do Édipo para Freud, como veremos. Entretanto, a lógica de epos refere-se à inscrição do sujeito em sua narrativa, como nos diz Dunker: "epos refere-se à origem de uma pessoa, comunidade ou grupo, mas segundo aquele que conta" (2008, p.4); (2) o mito apresenta uma função acentuada na determinação da vivência do neurótico. Em outras palavras, o mito individual do neurótico está presente como um conjunto de narrativas a partir das quais o neurótico tem suas experiências estruturadas. Podemos ver aqui uma primeira aproximação da função da inscrição do sujeito na linguagem, ou seja, da conjugação entre uma referência antropológica e uma histórica.

Ao avançar nesta via, Lacan tratará de explicitar a grade estrutural de transformação a partir da qual o drama do neurótico o liga ao das outras gerações. Nas palavras de Lacan:

A constelação - por que não no sentido de que falam dela os astrólogos -, a constelação original que presidiu ao nascimento do sujeito, ao seu destino e quase diria à sua préhistória, a saber, as relações familiares fundamentais que estruturam a união de seus pais, mostra ter uma relação muito precisa, e talvez definível por uma fórmula de transformação, com o que aparece como o mais contingente, mais fantasístico, o mais paradoxalmente mórbido de seu caso, último estágio de desenvolvimento de sua grande apreensão obsedante, roteiro imaginário a que chega como se fosse à solução da angustia ligada ao desencadeamento da crise. (LACAN, 1953a, p.19)

Nesta cita, Lacan atesta uma faceta do mito próxima ao ponto anterior e já cara à nossa incursão sobre suas delimitações na obra de Freud e Lévi-Strauss, qual seja: o 
mito aqui se apresenta como uma forma de agenciamento de posições que estruturam o que há de mais contingente na forma como o neurótico representa sua vivência. A sistematicidade deste agenciamento, entretanto, mostra-se em consonância com o modelo da fórmula canônica do mito, a partir do qual Lacan afirma aquela que seria mais uma característica do mito em sua obra:

O que da caráter mítico ao roteiro [imaginário do Homem dos Ratos] é o fato de encenar uma cerimônia que reproduz de forma mais ou menos exata a relação inaugural modificada numa certa tendência. Tudo se passa como se os impasses próprios da situação original se deslocassem para um outro ponto da rede mítica, como se o que não é resolvido num lugar se reproduzisse sempre noutro. [...] Existe no neurótico uma situação de quatuor [quaternária] que se renova o tempo todo, mas que não existe num único plano. (LACAN, 1953a, p.27)

O mito, nesta passagem, responde a um fenômeno que, em sua forma individual - encarnada na vivência do neurótico - mostra uma regularidade de transformação com os conflitos próprios de sua geração anterior. O mito individual, por essa via, articularia em uma dupla dimensão o drama do neurótico. Aqui já presenciamos uma aproximação à faceta do mito que consideramos de maior importância para o projeto de releitura da experiência psicanalítica tal como levado a cabo por Lacan a partir do início da década de 50, a saber, seu potencial de fornecer um modelo matemático de estruturação da organização de linguagem presente na constituição do psiquismo. Desse modo, repetimos nossa hipótese de que a entrada lacaniana na antropologia de Lévi-Strauss teria se dado através do potencial de formalização da posição do sujeito na linguagem pressuposto na "fórmula canônica do mito". Apresentaremos a forma como Lacan trata do caso do Homem dos Ratos no próximo capítulo, no entanto, vale aqui a menção à mais clara exposição de seu entendimento deste modelo de formalização, que opera tal qual operacionalizado no tratamento do caso de Freud.

A um $a$ associado a um $b$ e um $c$ a um $d$ trocam de parceiros na segunda geração, mas não sem que subsista um 
resíduo irredutível sob a forma de negativação de um dos quatro termos, que se impõe como correlativa à transformação do grupo: no que se lê o que chamaria de signo de uma espécie de impossibilidade da total resolução do problema do mito (LACAN, 1956, p.90).

$\mathrm{Na}$ rápida passagem aqui realizada pelas incidências e particularidades da noção de mito em $O$ mito individual do neurótico, portanto desde este momento constitutivo de sua entrada como elemento central do programa lacaniano de refundação das condições de leitura dos fenômenos clínicos, pudemos extrair, sinteticamente, as seguintes acepções:

1) $\mathrm{O}$ mito como modelo discursivo que apreende uma experiência inobjetivável. Neste momento o mito trata da possibilidade de falar da própria posição de enunciação do sujeito em sua divisão, em sua incompletude essencial (LACAN, 1966, p.233). O mito neste momento trata da posição do sujeito na linguagem, posição marcada por um impossível, no entanto, posteriormente, como veremos, Lacan fará recurso ao mito de forma mais próxima à abordagem freudiana: enquanto artifício teórico, o mito possibilitará abordar o real que escapa à simbolização.

2) Narrativa de estrutura ficcional homóloga à da noção de verdade. Tal faceta persistirá até o fim da obra de Lacan, pois a o mito seria o modo de portar a palavra que a pessoa encontraria para falar de seu desejo. O mito seria uma forma de falar da verdade que estrutura a vivência do sujeito, no entanto, esta verdade resiste à simples objetificação, uma verdade que só pode ser expressa parcialmente, semi-dita. Assim como o mito é necessário que seja redita indefinidamente.

3) Narrativa heroica que liga um sujeito à constelação original que presidiu ao seu nascimento. Liga o sujeito à coletividade de narrativas que permeiam sua inscrição individual. Neste ponto como dissemos, necessitamos diferenciar a confiança na universalidade de Édipo, por parte de Freud, da forma como Lacan assimila essa questão. Através da redefinição do estatuto significante dos elementos em jogo no Édipo, poderemos ver como para Lacan o mito de Édipo se torna um mito dentre outros possíveis, um enodamento universal de termos particulares. 
4) Mito como modelo de inscrição simbólica do neurótico na linguagem Neste ponto o mito é caracterizado como um conjunto de narrativas em torno de uma questão central ao neurótico: frente ao enigma do desejo do Outro, que toma as vezes de um questionamento sobre os fundamentos da lei e sobre a articulação entre desejo e gozo, o neurótico responde com seus mitos individuais. Em outros termos, diante do impossível da resposta, o mito forneceria na série de tentativas de recobrimento simbólico deste furo, o seu tratamento significante, possibilitando, assim, a formulação do que Lacan chama de significante do impossível (LACAN, 1956, p.91).

5) $\mathrm{O}$ mito como agenciador da experiência executa a articulação da contingência em torno dos conjuntos que compõem o sistema de contradições enodados e que estruturam e definem o mito como tal. Este ponto toca em alguns pontos anteriores, mas atentamos diferenciar esta função de ser um esquema significante agenciador de elementos de quaisquer natureza. O mito, tratado por sua função significante, também é determinante para o próximo ponto.

6) O mito como possibilidade de formalização da experiência analítica. Se em Freud, o mito daria testemunho do funcionamento do sistema psíquico, em Lacan, a partir de nossa leitura, o mito traria consigo um modelo de matematização de sua estrutura, com grandes influências sobre a teoria da constituição subjetiva. O modelo algébrico, aberto a derivações topológicas da "formula canônica do mito", marcaria o início de uma tentativa de recolocar a questão epistemológica da articulação da psicanálise como ciência. Tal princípio científico, pressuposto no projeto estruturalista, foi radicalizado por Lacan, a ponto deste primeiro conceito importado da antropologia lévi-straussiana servir de meta-modelo para uma série de outros esquemas propostos por Lacan para a formalização da experiência psicanalítica.

Não poderíamos considerar, nessa primeira aproximação da inserção da lógica do mito na obra lacaniana, uma função análoga a realizada por Totem e Tabu (1913) na obra freudiana? Ora, como vimos, a emergência do texto freudiano marcou para sua obra uma tentativa de inscrever em um tempo arcaico - portanto, nas bordas da história - uma narrativa que responderia à origem da cultura, assim como o papel do pai aí desempenhado, em seu papel articulador entre os temas da sexualidade e da morte. Entretanto, a lógica freudiana responde não responde apenas por uma teoria social, como a questões clinicamente relevantes, em especial sobre particularidades 
sintomáticas da neurose obsessiva. Se esta aproximação parece difícil na relação com os últomos pontos, não nos esqueçamos do valor epistemológico de Totem e Tabu para a teorização psicanalítica, ao situar nas origens da cultura e da vida em sociedade, uma construção hipotética, um "mito científico" que responderia por determinações universais do homem.

Tomando os seis pontos acima referidos como matrizes, parâmetros constitutivos da noção de mito na obra lacaniana, vejamos a partir deste momento, quais destinos foram dados no conjunto dos seminários e escritos de Lacan para a referência ao mito, assim como quais problemáticas estão associadas a ela. Esse percurso nos permitira reavaliar o valor de tal contribuição para sua leitura, assim como retomar as bases do diálogo com a antropologia estrutural.

\section{A noção de mito e seus destinos na obra lacaniana}

Como dissemos, o valor da noção de mito para a leitura da experiência clínica psicanalítica aparece desde os primeiros instantes da apropriação lacaniana do ideário estrutural, no interior do qual a antropologia foi responsável pela instrumentalização e valor técnico do fenômeno mítico (LACAN, S.IV). Em um comentário sobre o tal momento, Lacan diz:

Sem dúvida, o praticante não empedernido não é insensível a uma realidade tornada mais nostálgica por ser provocada no encontro com ele e, nesse caso, responde a relação essencial do véu com sua experiência através dos esboços de mito. (LACAN, 1966, p.233).

Ao trazer a figura do "praticante não empedernido", não insensível à dinâmica própria do tratamento analítico, Lacan busca aproximar-se de um leitor que reconheça em sua teorização a ruptura com os modelo de entendimento e transmissão da clínica psicanalítica dominante no início da década de 50 - com seus efeitos ainda presentes atualmente -, ruptura esta que teria como lastro fundamental uma profunda revisão dos condicionantes particulares à própria experiência clínica. 
A dimensão simbólica da experiência, aquela na qual se desloca o discurso, implica na assunção básica de que o sujeito diz mais do que pensa dizer (LACAN, S.I, p.68), em suma, na assimilação da hipótese de uma instância inconsciente de determinação da subjetividade. Como define Lacan em Função e campo:

Seus meios [da psicanálise] são os da fala, na medida em que ela confere um sentido às funções do indivíduo; seu campo é o do discurso concreto, como campo da realidade transindividual do sujeito; suas operações são as da história, no que ela constitui a emergência da verdade no real. (LACAN, 1953b, p.258).

Como já vimos em $O$ mito individual, a busca de Lacan por reunir uma dupla referência estrutural e dialética, o faz aproximar a noção de inconsciente da ideia de verdade - verdade do desejo, do sintoma, do sujeito que padece por sua alienação. Verdade cuja emergência depende de uma "operação", inserida no tempo, própria ao progresso da fala presente.

\subsection{O mito como expressão de uma verdade}

O inconsciente, desde o início da década de 50, será definido "como parte do discurso concreto, como transindividual, que falta a disposição ao sujeito para restabelecer a continuidade de seu discurso consciente" (LACAN, 1953b, p.260), em outros termos, como o discurso do Outro que supera sua apreensão e o determina. A abrangência dessa determinação implica a quase totalidade das vivências humanas, como já salientava Lévi-Strauss, sendo parte integrante, portanto, da experiência clínica, na qual, como nos diz Lacan, há uma cooptação de uma relação atual, do registro do hic et nunc, para a efetivação de uma "realidade mais nostálgica", formada pelas históriasnarrativas (denominadas aqui, por Lacan, como discurso concreto) que presidiram ao nascimento daquele sujeito. Nos termos do psicanalista francês: a narrativa, a fala atual implica um "epos que relaciona com o momento presente, as origens da pessoa" (Ibidem, p.256). A inscrição da dupla dinâmica temporal própria à experiência analítica, faz Lacan inserir o discurso aí veiculado em duas vertentes, a depender de seu potencial de eficácia simbólica: refiro-me aqui às noções de fala vazia e fala plena. 
Estas duas noções pouco renderam no conjunto da obra lacaniana, pois como sabemos elas persistem apenas nos primeiros anos de seu Seminário, mas mostram ai a influência da concepção lévi-straussiana da função simbólica no tratamento, como vimos no capítulo anterior. Se a palavra vazia pode ser entendida como aquela que não teve seu lugar simbólico reconhecido e sancionado, ou seja, que se atém simplesmente ao seu valor presente no aqui e agora do discurso; a palavra plena, pode ser entendida como aquela que permite a integração da dimensão simbólica, que "reordena as contingências passadas dando-lhes o sentido das necessidades por vir" (Ibidem, p.254), portanto, constitui-se como uma forma discursiva que, por estar inserida na relação muito particular da experiência analítica, permite a reinscrição da narrativa do sujeito na tensão fundante com a dimensão oculta da verdade de seu desejo. Em outros termos:

A palavra plena é a que visa, que forma a verdade tal como ela se estabelece no reconhecimento de um pelo outro. A palavra plena é palavra que faz ato. Um dos sujeitos se encontra depois outro que não o que era antes. E por isso que essa dimensão não pode ser eludida da experiência analítica. (LACAN, S.I, p.129).

Dentre as condições explicitadas por Lacan para realização de desse ato transformador próprio à fala plena, temos a "operação" mencionada a pouco, que permitiria a "emergência da verdade no real": conjugada à dinâmica do tratamento, esta operação se remete à lógica transferencial, propiciada pelas características intrínsecas da palavra de unir sujeitos humanos (Ibidem). Ora, assim como em Lévi-Strauss, a transferência foi concebida como a atualização de um mito individual, ou uma versão para sermos mais exatos, em Lacan encontramos a possibilidade de realização simbólica do sujeito com referência à verdade da qual se encontra alienado. Ela marca a particularidade do mito de não se constituir apenas como um regime narrativo, mas uma modalidade discursiva que lhe permite ser conjugados com a dinâmica ritual, ser vivido intensamente. Entretanto, o mito também se faz aí presente:

Toda dialética da rivalidade, passivante para ele [Homem dos Lobos], com o pai, será, em certo momento, inteiramente distendida pela intervenção de personagens carregadas de prestígio, tal ou tal professor, ou, anteriormente, 
pela, introdução do registro religioso. O que Freud nos mostra, pois, é isto - é na medida em que o drama subjetivo é integrado num mito que tem um valor humano extenso, e mesmo universal, que o sujeito se realiza. (LACAN, S.I, p.221)

Aqui, ao comentar o caso freudiano do Homem dos Lobos, Lacan salienta o papel na "realização do sujeito" que exerce a inscrição do drama individual em um mito de valor universal. O mito, por esta via, entra como uma narrativa transindividual, da ordem do discurso, que dá as coordenadas simbólicas do sujeito em sua epopeia particular, é ele que permite ao sujeito reconhecer as linhas de força que guiam seu destino, à sua revelia, e que respondem pela verdade de seu desejo. É justamente a partir de sua virtude simbólica, que Lacan relerá os mitos fundantes da teorização psicanalítica - Édipo, Totem e Tabu e Moisés - assim como, no âmbito da clínica, buscará reler a função das estruturas míticas no determinismo dos sintomas, como iniciara em $O$ mito individual (LACAN, S.VIII, p.390). Acerca da dinâmica estrutural dessas narrativas, tomemos sua apresentação mais sistemática sobre o tema, situada no seminário IV:

$\mathrm{O}$ que se chama um mito, seja ele religioso ou folclórico, em qualquer etapa de seu legado que se o considere, apresenta-se como uma narrativa. Pode-se dizer muita coisa sobre esta narrativa, e toma-la sob diferentes aspectos estruturais. Pode-se dizer, por exemplo, que ela tem alguma coisa de atemporal. Pode-se tentar definir sua estrutura quanto às configurações que ela define. Pode-se toma-la sob sua forma literária, cujo parentesco com a criação poética é surpreendente, ao passo que o mito é, ao mesmo tempo, muito distinto desta, no sentido que demonstra certas constâncias que não estão absolutamente submetidas à invenção subjetiva. (LACAN, S.IV, p. 258 - grifo meu)

Até este ponto, ao tomarmos como referência os mitos produzidos fora e dentro da experiência clínica psicanalítica, não somos remetidos a um entendimento distinto daquele encontrado na teoria lévi-straussiana. Enquanto uma narrativa que transcende a subjetividade individual, o mito aparece como o lugar da determinação de linguagem 
sobre o homem, tal qual operado pela função simbólica. Entretanto, como salientamos, esta primeira faceta do mito em Lacan tem como particularidade sua articulação com a verdade do sujeito:

Vou indicar também o problema suscitado pelo fato de que o mito tem, no conjunto, um caráter de ficção. Mas esta ficção apresenta uma estabilidade que não a torna de modo algum maleável às modificações que lhe podem ser trazidas, ou, mais exatamente, que implica que toda modificação implica por sua vez, por essa razão, uma outra, sugerindo invariavelmente a noção de uma estrutura. Por outro lado, essa ficção mantem uma relação singular com alguma coisa que esta sempre implicada por trás dela, e da qual ela porta, realmente, a mensagem formalmente indicada, a saber a verdade. Aí esta uma coisa que não pode ser separada do mito ${ }^{26}$. (Ibidem, p.259).

A asserção da impossibilidade de separação entre as temáticas do mito e da verdade, impele-nos a rever as condições de aproximação entre suas estruturas. A verdade, como diz o famoso aforisma lacaniano, possui uma estrutura de fíç̧ão (Ibidem, p.260), ou seja, ela se expressa estruturalmente na constituição da fala, consequentemente na própria emergência da construção de uma ficção. Ao falar de seu passado, e.g., o relato de um sujeito não se apresenta como uma versão neutra da pretensa "realidade" dos fatos, mas, antes, como uma narrativa que o inclui, enquanto sujeito, no papel estruturante de tal narrativa, que denuncia em sua construção a verdade que o constitui e que demanda reconhecimento pelo Outro. $\mathrm{O}$ mito, da mesma forma, por se caracterizar como uma matriz inesgotável de construções, posto que é da ordem da fala, oferece um esquema - no sentido kantiano - de valor estruturante, que exprime uma verdade da relação do homem as condições de possibilidade de sua experiência. Nas palavras de Lacan:

\footnotetext{
${ }^{26}$ No comentário de Simanke: A antropologia pode aplicar estritamente o método estrutural, já que os produtos sobre os quais ela aplica - os mitos - estão, de certa forma, acabados, por mais que possam continuar se produzindo. Mas o psicanalista assiste a essas versões da mitologia individual se produzindo, ao vivo e a cores, diante de seus olhos ou se sua escuta, e não pode, sob o risco de descaracterizar sua experiência, abstrair o sujeito que as produz. (SIMANKE, 2002, p.486)
} 
Cabe a nós, apenas, perceber que se trata de temas da vida e da morte, da existência e da não-existência, do nascimento, em especial, i.e., da aparição daquilo que ainda não existe. Trata-se pois, de temas ligados, por um lado, à existência do próprio sujeito e aos horizontes que sua experiência lhe traz, por outro lado, ao fato de que ele é o sujeito de um sexo, do seu sexo natural. Aí está ao que nossa experiência nos mostra que a atividade mítica se emprega na criança. Ela demonstra, assim, por seu conteúdo e por sua visada, completamente de acordo - sem recobri-lo completamente - com o que se inscreve sob o termo próprio de mito na exploração etnográfica (LACAN, S.IV, p.261 - grifo nosso).

Ao trazer o tema das teorias sexuais infantis, categoria central quando buscará fazer uma análise mítica das narrativas reproduzidas no relato do caso freudiano do pequeno Hans, Lacan se aproxima da posição sobre o mito que vimos em Freud. Tanto lá como aqui, é central a estabilidade das narrativas produzidas pelas crianças em sua investigação sobre a identidade sexual. Em ambos, devemos ressaltar, essa atividade de pesquisa da criança não é entendida como uma atividade intelectual, mas antes, como uma atividade que "concerne ao conjunto do corpo. Envolve toda a atividade do sujeito, [...] dirige os afetos e afeições de acordo com as linhas mestras de imagens" (LACAN, S.IV, p.256). As séries míticas produzidas pelas crianças, em correlação com as mitologias recolhidas em campo, visam a origem do mundo, àquilo que posicionam em pé o homem no mundo, e recolhem aí, como veremos à frente, os "significantes primordiais através dos quais estabelecem suas relações e concebem sua genealogia. Ordem das significâncias que permitem, a um ser humano reconhecer seu lugar aí” (LACAN, S.III, p.234). O lugar simbólico no conjunto de relações do sujeito, com todo o valor existencial aí implicado, é justamente aquilo que o mito, no seu conjunto de transformações, procura expressar. Nos termos de Lacan:

A sucessão de fantasias do pequeno Hans deve ser, realmente, concebida como um mito em desenvolvimento, um discurso. Não se trata de outra coisa, na observação, senão de uma série de reinvenções desse mito com auxílio de elementos 
imaginários. Trata-se de compreender a função desse progresso rotativo, dessas sucessivas transformações do mito, e daquilo que, num nível profundo, representa para Hans a solução do problema, o de sua própria posição na existência, na medida em que ela deve se situar com relação a uma certa verdade a um certo número de referências de verdade, nas quais ele deve tomar seu lugar (LACAN, S.IV, p.353)

O mito, portanto, em seu potencial de articulação com a verdade, encarna a relação o homem com o significante, ou melhor, de como ela define seu drama, ahistórico por essência, "inscrito até na carne dos homens, na origem de toda a história" (LACAN, S.III, p.235). Eis o ponto onde toca a dinâmica descrita por Freud em $O$ romance familiar do neurótico (1909), na qual encontramos narrativas que buscam, a partir do reposicionamento dos personagens principais, reconfigurar o lugar do sujeito em sua história. A mítica individual aí implicada, mostra como o valor do mito para a psicanálise está para além de uma noção acerca das produções fantásticas, ou teoria do mundo, ela busca articular o lugar do sujeito frente aos seus conflitos fundantes. A premência pela explicitação da lógica mítica na psicanálise é tanta que, afirma Lacan, Freud se viu impossibilitado de evitar "na coerência de sua teoria" a construção de um mito misterioso como o de Totem e Tabu.

$\mathrm{Na}$ trilha de conceber o mito como uma forma de expressão de uma verdade, enquanto dimensão inobjetivável da experiência, que toma o sujeito quase por completo em seu nível de determinação, Lacan recorrerá, no seminário VIII, tratando do diálogo socrático $O$ Banquete, à imagem daquilo que está para além de um saber claro e transparente, de uma positividade conhecível, para se referir ao mito. Em seus termos:

Quando se chega, e em muitos outro campos além daquele do amor, a um certo termo que não pode ser obtido no plano da episteme, do saber transparente a si mesmo, para ir mais além, é necessário o mito. É muito concebível para nós que haja um limite ao plano do saber, se este é unicamente aquilo que é acessível fazendo-se jogar, pura e simplesmente, a lei do significante. $\mathrm{Na}$ ausência de conquistas experimentais bastante 
avançadas, é claro que em muitos domínios, e em domínios dos quais não temos necessidade, será urgente passar a palavra ao mito. (LACAN, S.VIII, p.154)

O mito, aqui relido pela expressão muthos legein, ou seja, um misto de história precisa e discurso, aquilo que se diz, aparece, em sua dimensão narrativa, como passível de oferecer uma expressão significante aos fenômenos que são definidos essencialmente por sua negatividade na relação ao sujeito, do qual é expressão e efeito. Como veremos a respeito das formas de impossível a que Lacan remeterá a lógica mítica, ele permite ao teórico lidar com um saber dos limites, um saber daquilo que está infinitamente na borda a se conhecer, mas que apenas se constitui como condição de possibilidade da produção de um saber.

Se o Seminário VIII marca o início de uma referência à articulação do mito com a registro do real da experiência, à frente tratado, a partir do seminário XVII a ligação entre o mito, o saber e a verdade receberá um configuração ligeiramente distinta. Aí encontramos:

Por que Freud substitui o saber que recolheu de todas essas bocas luminosas, Ana, Emmie, Dora, por esse mito, o complexo de Édipo? O Édipo desempenha o papel do saber com pretensão de verdade, quer dizer, do saber que se situa, na figura do discurso do analista no lugar que designei há pouco como o da verdade. [...] O que advém do saber no lugar da verdade no discurso do analista é o mito. (LACAN, S.XVII, p.86)

A teoria dos discursos formulada por Lacan, a partir do fim dos anos 60, marca, entre outras contribuições, uma revisão no potencial de inserção da psicanálise no interior do grande campo da teoria social. O termo discurso aqui será tratado não mais como simples discursividade intersubjetiva, da ordem do que se articula no dizer, mas se aproximará da conceituação dos determinantes do "laço social, fundado na linguagem" (LACAN, S.XX, p.21). Das quatro formas de discurso apresentadas por Lacan, no interior do qual teríamos todas as modulações dos laços entre os sujeitos, o discurso do analista, produz uma forma de inscrição diferente do saber. Após ressituar neste contexto o conceito de inconsciente, como "um lugar no qual se enuncia uma 
verdade que tem a propriedade de nada podermos saber dela. Fato este que constitui um saber" (LACAN, S.XVI, p.198), o psicanalista concebe uma forma de saber, inconsciente por essência, que sustenta uma verdade que não se sabe, nem sabível.

De forma esquemática, os quatro discursos apresentam "quatro modalidades de laços sociais que dão aos ditos diferentes sentidos segundo os lugares de onde são emitidos e a quem são endereçados" (PORGE, 2009, p.124). Suas posições fundamentais são ocupadas por quatro termos se intercambiam entre si, de forma a representar as formas fundamentais de laço. Como podemos ver na figura abaixo, extraída de Radiofonia (LACAN, 1970, p.447):

Discurso do Mestre

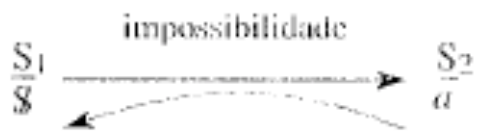

esclarecido por

regressẫo clo:

Discurso da listérice

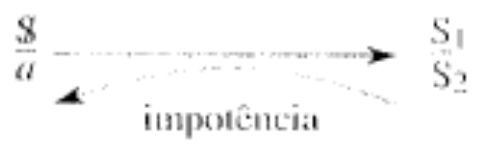

Discurso da Universidade

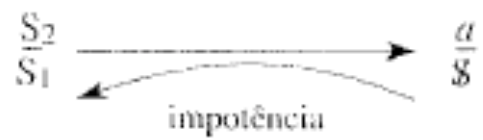

sclarectido por sua

"progressîu" para o:

Discurso de Analista

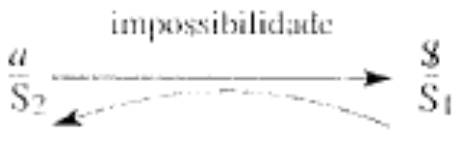

Os lugares sion de:

$$
\frac{\text { o aucute }}{\text { a verdiate }} \quad \frac{\text { ooutro }}{\text { at produçāo }}
$$

Retomando o postulado lacaniano de que o mito expressa o saber que ocupa o lugar da verdade, temos a consideração de que toda e qualquer tentativa de articulação de um saber de ordem do inconsciente, passa em algum nível por uma construção mítica, como pudemos ver na obra freudiana desde os primeiros momentos de empreitada pela clínica psicanalítica. Entretanto, a relação entre a verdade e o mito resguarda ainda uma relação mais fundamental nessa articulação pela formulação dos 
discursos: após apresentar tal postulado, Lacan remeterá seus ouvintes à leitura de $A$ estrutura dos mitos, de Lévi-Strauss, por uma razão central para este estudo:

Evidentemente, ali verão enunciada a mesma coisa que o que lhes digo, a saber, que a verdade só se sustenta em um semi-dizer. [...] A impossibilidade de por em conexão grupos de relações - trata-se de montes de relações, como ele define os mitos - é superada, ou mais exatamente, substituída pela afirmação de que duas relações contraditórias entre si são idênticas, na medida em que cada uma dela é, como a outra, contraditória consigo mesma. Em suma, o semi-dizer é a lei interna de toda espécie de enunciação da verdade, e o que melhor a encarna é o mito. (LACAN, S.XVII, p.90).

O mito portanto, busca dar expressão significante a uma verdade que não pode ser toda dita, toda sabida. Se vimos em $O$ mito individual, que o fenômeno mítico tem com a verdade, posto que é da ordem da fala, essa relação constituinte de sempre renovar sua de expressão, de incessantemente tomar novas configurações, novas versões na tentativa transmitir sua mensagem, na articulação da teoria dos discursos, ele passa a representar essa forma muito peculiar de transmissão de um impossível, de um saber insabido produzido no lugar da verdade. A mensagem chega a seu destinatário, mas apenas por meio de um saber inarticulável, transmitido por essa modalidade de discurso impossível que não faz semblante, que não oculta a incompletude do sujeito aí implicado, o sujeito dividido da psicanálise. Retomaremos as implicações desta articulação à frente. Vejamos agora como o modelo de formalização do mito, em especial aquele concretizado na fórmula canônica do mito, foi central na apropriação do sistema de linguagem por Lacan.

\subsection{A estrutura dos mitos como projeto global de formalização: da lógica do mitema ao significante lacaniano}

Como vimos, a psicanálise lacaniana encontra na linguística estrutural e na derivação de método realizada pela antropologia - marcada pela expansão de sua matriz aos fatos socioculturais - um modelo de linguagem central para o projeto de 
formalização da clínica, em especial, dos determinantes da ordem simbólica, com efeitos incontornáveis para a teoria da constituição do sujeito.

Ao assimilar a terminologia da linguística saussureana, em especial, os conceitos de significante e significado, Lacan já o realiza sob a perspectiva da fonética de Jakobson e da Escola de Praga, que se distingue por privilegiar o primeiro termo, em detrimento do último (Cf. BEIVIDAS, 2001, p.322). Apresentamos no capítulo anterior como o projeto lévi-straussiano, de levar às últimas consequências a explicitação da determinação significante sobre os fatos sociais, opera uma passagem do modelo de $A s$ Estruturas Elementares (1949a), para o de A estrutura dos mitos (1955), passando pelo seminal Introdução à obra de Marcel Mauss (1950).

Em ambos, encontramos uma caracterização do significante como procedendo por uma lógica similar: cada termo, ou unidade constitutiva mínima do sistema, seja o fonema, o mitema, ou parentema, etc., não possui um significado intrínseco, nem produz por sua identidade isolada uma significação própria. Como matriz da lógica simbólica, o significante, enquanto elemento discreto que precede e determina o significado (LÉVI-STRAUSS, 1950, p.29), é entendido, ou melhor, retira seu sentido de uma posição diferencial no conjunto de todos os outros significantes. Em termos práticos, o significante livro, nada possui de intrínseco com o objeto que designa, seu referente, nem com o grupo de significados, conceitos, a ele atribuído, mas retira seu valor terminológico de sua oposição com os demais termos da língua. Até aqui nenhuma grande novidade para um estudioso do método estrutural.

Entretanto, uma nova determinação se faz necessária. Tanto na linguística estrutural, como no modelo apresentado n'As Estruturas, a unidade constitutiva mínima, procede de termos facilmente identificáveis, localizáveis seja nas partículas mínimas da língua, como traços diferenciais do quadro de fonemas, seja nos termos do parentesco (Pai, Mãe, Tio, etc.) e no conjunto de suas oposições (célula do avunculado). Outros termos estão presente quando da análise da estrutura mítica.

Ao se deter sobre as narrativas míticas, Lévi-Strauss apresenta o mitema, como vimos, a partir da ideia de uma unidade formada por um conjunto de relações, relações entre relações. Ao abrir sua análise estrutural ao nível do discurso, o antropólogo forja uma unidade constitutiva mínima não apreensível em sua imediaticidade. Diferente da análise do parentesco, onde pode-se identificar os termos mínimos de onde se 
depreenderão as oposições fundamentais do parentema, na análise mítica estes termos são difusos. Os mitemas são dificilmente identificáveis e dependentes, como vimos, de uma série de contextualizações, inscrições de suas determinações na cena da qual foi extraído, o que explica sua variabilidade e flutuação de leituras. Esse fator contribuiu enormemente para o pouco rendimento do modelo da formula canônica do mito nos trabalhos dos herdeiros intelectuais de Lévi-Strauss. A despeito das poucas apresentações de sua funcionalidade, a indeterminação impressa na fórmula do antropólogo dificulta a transmissão e verificação de seus postulados, o que teve como decorrência seu posicionamento como uma categoria secundária, quase ausente entre os pós-lévi-straussianos. No entanto, a abertura hermenêutica propiciada pelo modelo de Lévi-Strauss, foi lida por Lacan como uma virtude na qual este reconhece o cerne da apreensão psicanalítica do significante.

Assim como nos mitos coletivos, as relações fundamentais do mito individual de cada sujeito não são dados a priori. A modulação das oposições, assim como os termos que lhes constituem, devem ser apreendidos no tempo - à semelhança do mito como aquilo que decanta das transformações intrínsecas ao conjunto de versões. A noção de transferência se insere aqui, portanto, não como apenas como um contexto expressivo dos conflitos constitutivos, como um meio produtivo a partir do qual novas versões do mito surgirão. Dessa forma, o significante lacaniano, em todo sua potência de determinação do sujeito em seus atos, articulam relações e são apreendidos após um agrupamento de diferentes versões da questão mítica central. Este fato, definiria, o mito, justamente, como o meio no qual a natureza do valor relacional significante é mais sensível (LACAN, S.IV, p.260). Ao comentar a complexa evolução da fobia de Hans, cuja análise nos moldes de um mito é um dos motes do seminário IV, Lacan nos diz:

Mais vale tentar ver as funções, os elementos representativos, figurativos, que elas nos trazem, como essas narrativas muito articuladas que são os mitos antigos. Temos o hábito de dar, aos termos em jogo, equivalentes em profusão, dizendo: isso representa o pai, isso representa a mãe, isso representa o pênis. Ora, cada um dos elementos, o cavalo, por exemplo, só é concebível em sua relação com um certo número de outros elementos igualmente significativos. É impossível fazer corresponder o cavalo, não mais que qualquer outro dos 
elementos dos mitos freudianos, a uma significação unívoca. $\mathrm{O}$ cavalo é, inicialmente, a mãe, o cavalo é no final o pai, entre ambos ele também pôde ser o pequeno Hans que, com efeito, de vez em quando brinca de cavalo, ou ainda o pênis, do qual o cavalo é, manifestamente, o representante em diversos pontos da história (LACAN, S.IV, p.282)

O conceito freudiano de sobredeterminação é central aqui. Ao fazer do significante lacaniano um conjunto que agrupa relações entre relações, Lacan transforma sua apropriação conceitual do léxico linguístico, sob a chave do modelo lévistraussiano do mitema. Em uma frase, e essa é uma hipótese que busco sustentar neste tópico, podemos dizer que o modelo de formalização de linguagem inaugural e com reverberações profundas no conjunto da obra lacaniana, não foi aquele postulado por Saussure ou por Jakobson, mas aquele sustentado por Lévi-Strauss em A estrutura dos mitos.

A definição do estatuto do significante é inseparável necessariamente de um postulado de método para alcançar sua realidade estrutural. Na continuidade da discussão sobre os modos de recorte de significantes, Lacan nos diz:

É necessário que se esforcem, em cada etapa, em cada momento da observação, para não compreender imediatamente. Esta é uma questão de método. É preciso que se esforcem, como Freud lhes recomenda expressamente, por não compreender de imediato. A melhor maneira de não compreender é fazer um fichamento e anotar dia a dia, numa folha de papel, os elementos que Hans aborda e que se devem compreender como tais, como significantes. Insisti, por exemplo, no sozinho com Mariedl. Se não entenderem nada disso, guardem este elemento significante e, como a inteligência lhes virá quando estiverem comendo, vão perceber que isso se recorta estritamente com algo de diferente que vão poder escrever na mesma folha. [...]. Este método de análise dos mitos é o que nos foi apresentado pelo sr. Claude Lévi-Strauss num artigo do Journal of American Folklore de 
outubro-dezembro de 1955, intitulado "A estrutura dos mitos". (LACAN, S.IV, p.283).

Ao aproximar a estrutura e método de apreensão dos significantes dá lógica proposta por Lévi-Strauss - com seus sistema de anotação em fichas, mitemas, etc. Lacan insere aí a dimensão diacrônica, suposta na essência da fala, como condição de possibilidade de formalização clínica. $\mathrm{Na}$ leitura dos elementos significantes fundamentais que regulam a vivência do sujeito, o psicanalista deve se ater às repetições de sua narrativa, assim como a possibilidade de múltiplas incidências e significações daquilo que se repete.

O significante sintomático é constituído de maneira tal que é de natureza a recobrir, no decorrer do desenvolvimento e da evolução, múltiplos significados, e os mais diversos. Não apenas é de sua natureza fazê-lo, mas esta é também a sua função. (LACAN, S.IV, p.294)

É exatamente aí que caberá ao psicanalista intervir em sua clínica. Ao pontuar uma incidência significante, recortar sua posição do discurso imediato, o analista permite que uma subjetividade, "cuja sintaxe é engendrada pela marca significante" (LACAN, 1955, p.55), reordenar a inscrição de seu lugar na ordem dos discursos que marcaram sua constituição. Eis onde a diacronia acima tratada, própria da produção mítica, incide sobre a diacronia própria às transformações operadas, através da atualização da mítica individual, no interior do tratamento analítico. Tal atualização, no contexto produtivo da transferência, deve ser vista, como já nos indicava Lévi-Strauss (1949b) como uma repetição diferenciante, uma versão que imprime uma versão mítica que no processo da ritualística própria a um tratamento inscreve a diferença na experiência analítica.

Observemos agora como o modelo das transformações míticas de Lévi-Strauss propicia ainda um metamodelo de formalização para o pensamento lacaniano. 


\subsection{A fórmula canônica do mito e sua estrutura quaternária}

A fórmula proposta por Lévi-Strauss em $A$ estrutura dos mitos, tratada no capítulo anterior, apresenta um sistema quaternário na qual se equacionam dois pares de contradições. A partir de uma contradição insolúvel, da ordem do impasse, um mito é construído de forma a dar expressão significante a tal oposição, por meio da aproximação com outras contradições (LÉVI-STRAUSS, 1955, p.232). Esta característica a distingue, em uma primeira instância, do modelo quaternário do parentesco, posto que a articulação entre os termos não envolverem, por princípio, uma contradição, mesmo que no avunculado se forme posteriormente um sistema de atitudes opostas. Na formação do quadro de um sistema de relações, uma oposição é definido por um topologia suposta por um modelo simples de relação, um elemento se encontra em um lugar diferencial em relação ao outro. A contradição, por outro lado, implica um modelo duplo de relação, além da definição de cada elemento de forma diferencial, ele é inserido em uma relação que se sobrepõe à primeira, na qual passa a ser determinado pela sua oposição frente ao outro elemento. Por esta via, vemos que a escolha do léxico pelo antropólogo não é fortuita frente à caracterização do sistema significante suplementar impresso pela lógica do mito.

Entretanto, encontramos ainda uma segunda característica que define a fórmula de Lévi-Strauss: refiro-me aqui ao fato de sua estrutura ser sustentada essencialmente por contradições heterogêneas, não situadas na mesma dimensão, ou mais exatamente, pela especificidade de seu último termo não ser do mesmo plano formal que os demais. Podemos dizer que os primeiros se encontram ao nível do discurso comum, entretanto, aquele representado na dupla torção final apresenta um estatuto heterogêneo frente aos demais. Algo similar se encontra no sistema do parentesco, no qual o tio materno coloca-se como um articulador daquele núcleo ternário com a totalidade do socius. Entretanto, a diferença deste com os outros termos, marca antes uma diferença de posição, não de qualidade.

Como vimos, a noção de mito individual remete à mítica imaginária construída por um sujeito, que explicita, a partir de uma série de transformações entre seus campos de incidência, a determinação dos discursos que "presidiram ao seu nascimento". O mito sempre se funda na tentativa de articular um problema impossível, fazer a passagem, a mediação de uma contradição irresolúvel. Nos termos de Lacan: 
Trata-se de passar de um certo modo de explicação da relação-com-o-mundo do sujeito ou da sociedade em questão para outro modo - sendo esta transformação requerida pela aparição de elementos diferentes, novos, que vêm contradizer a primeira formulação. Eles exigem, de certo modo, uma passagem que é, como tal, impossível, que é um impasse. Isso é o que dá sua estrutura ao mito. (LACAN, S.IV, p.300)

No ponto anterior, tratamos da diacronia pressuposta na noção de mitema, entretanto, a partir da ideia de mediação, podemos ver uma outra inscrição da diacronia no pensamento estrutural lacaniano: um mito implicaria a tentativa de passagem de um estado a outro, de articulação de uma falta primordial no cerne da relação do sujeito com o Outro, ou com sua inscrição nesta matriz simbólica que é a linguagem. Na tentativa de mediação entre essas duas posições incongruentes, o mito estabelece uma série de correlações que denunciam sua estrutura. Nas razões do psicanalista:

Para aqueles que deixaram passar as coisas, ou que não o sabem, vou dizer o que e a articulação estruturalista do mito. Tomando um mito em seu conjunto, quero dizer o epos, a história, a maneira pela qual isso é contado do começo ao fim, constrói-se um modelo unicamente constituído por uma série de conotações opostas de funções interessadas - por exemplo, no mito do Édipo, a relação pai-filho, o incesto, etc. [...] Percebe-se que o mito não para ali, que existem as gerações seguintes. Se é um mito as gerações não são simplesmente a sequência da entrada dos atores, o fato de que, quando os velhos caem, há jovens que vem para que isso recomece: o que nos interessa é a coerência significante que existe entre a primeira constelação e aquela que se segue. (LACAN, S.VIII, p.310)

Como aponta Lacan nesta citação, o modelo de Lévi-Strauss, imprime sobre a interpretação das produções míticas, não apenas relações lógicas de equivalência como de analogia, homologia, p.ex. - mas regras de transformação entre os termos. Em outras palavras, a análise dos mitos em Lévi-Strauss aponta para uma topologia própria 
do significante ${ }^{27}$. A entrada de novos "atores", implica na necessária produção de transformações a serem conjugadas em um sistema simbólico. Ao comentar este ponto, ele nos diz:

Este é um jogo no qual se trata de detectar as regras que lhe dão rigor. E reparem que não ali outro rigor concebível além daquele que se instaura justamente no jogo. Na função do mito, em seu jogo, as transformações se operam segundo certas regras, que por esse motivo tem um valor revelador, criador de configurações superiores ou de casos particulares iluminadores. Em suma, demonstram a mesma espécie de fecundidade que as matemáticas. É disso que se trata na elucidação dos mitos. E isso nos interessa da maneira mais direta, já que não nos é possível abordar o tema com que lidamos na análise sem encontrar a função do mito. (LACAN, S.VIII, p.311).

Desde sua primeira apresentação da "coerência" do sistema significante, em $O$ mito individual, Lacan expõe as proposições fundamentais da estrutura quaternária do mito. O modelo de transformação, cujo valor de formalização matemático, Lacan reconhece no trecho acima, aproxima-se ainda mais da fórmula lévi-straussiana, na referência inaugural que encontramos em sua conferência de 1953. Nesta citação, já apresentada acima, encontramos:

As relações familiares fundamentais que estruturam a união de seus pais [do Homens dos ratos], mostra ter uma relação muito precisa, e talvez definível por uma fórmula de transformação, com o que aparece como o mais contingente, mais fantasístico, o mais paradoxalmente mórbido de seu caso, último estágio de desenvolvimento de sua grande apreensão obsedante, roteiro imaginário a que chega como se fosse à solução da angústia ligada ao desencadeamento da crise. [...]Tudo se passa como se os impasses próprios da situação original se deslocassem para um outro ponto da rede mítica,

\footnotetext{
${ }^{27}$ Para maiores avanços no tema, remeto o leitor ao trabalho de Paulo Rona, "O Significante, o Conjunto e o Número - A topologia na psicanálise de Jacques Lacan” (2013).
} 
como se o que não é resolvido num lugar se reproduzisse sempre noutro. [...] Existe no neurótico uma situação de quatuor que se renova o tempo todo, mas que não existe num único plano. (LACAN, 1953a, p.28-9)

O neurótico, como aqui concebe Lacan, encontra-se em sua vivência numa situação quatuor persistentemente reinscrita, ou melhor, numa posição diplópica ${ }^{28}$ através da qual acha-se impossibilitado de unificar, no caso relacionado aí, os planos de sua relação com o trabalho e os frutos deste, a que Lacan denomina sua "função viril e no trabalho" (Ibidem, p.29); e aquele ligado à possibilidade de gozar de forma serena e unívoca do objeto sexual. Essa cisão tem como determinante o fato de sua vivência sintomática estar determinada por um conjunto de conflitos presentes na geração passada, ou ao menos no discurso constitutivo dos momentos primordiais de sua expressão subjetiva - portanto, uma segunda incidência da disparidade de planos em que se passa o drama do neurótico. Este quatuor, cuja expressão quaternária já encontramos no modelo de Lévi-Strauss (1955), implica uma modificação no entendimento clínico de uma das bases da teoria psicanalítica tal como entendida nos início dos anos 50 pela comunidade analítica, como vemos a seguir:

O sistema quaternário, tão fundamental nos impasses, nas insolubilidades da situação vital dos neuróticos, tem uma estrutura bem diferente da dada tradicionalmente - o desejo incestuoso pela mãe, a interdição do pai, seus efeitos de barreira e, em torno disso, a proliferação mais ou menos luxuriante de sintomas. Creio que essa diferença deveria nos levar a discutir a antropologia geral que se depreende da doutrina analítica tal como foi ensinada até agora. Numa palavra, todo o esquema do Édipo deve ser criticado. (LACAN, 1953a, p.39).

A possibilidade entrevista de revisão das matrizes de compreensão do complexo de Édipo, um dos pilares basais da leitura da experiência analítica, já se mostra suficiente para que víssemos na teoria lévi-straussiana uma obra incontornável

${ }^{28}$ A diplopia é um fenômeno óptico resultante da impossibilidade de se focar dois objetos diferentemente distantes do observador, o que faria com que, ao se focar um destes, o outro se duplique no campo de visão, sendo a situação inversa semelhante. 
para a formação analítica. Lacan mesmo, não deixou de reconhecer inúmeras vezes sua divida para com o antropólogo, pelo potencial de formalização que seus postulados - e a lógica matemática aí pressuposta - propiciaram à teoria psicanalítica. Antes de apresentar a releitura do Édipo, assim como o papel aí desempenhado pelo quarto elemento, consideremos uma importante implicação da importação lacaniana do modelo da fórmula canônica do mito, a saber, seu papel sobre os esquemas, modelos e grafos construídos por Lacan ao longo de sua obra.

\subsection{A fórmula canônica do mito como meta-modelo de formalização}

O modelo da fórmula canônica sustentado por Lévi-Strauss, como vimos, assimila em si uma articulação de contradições heterogêneas. Por esta via, ela traz a marca de uma impossibilidade de resolução da situação, desdobrada em dois tempos, posto que há uma falta constitutiva em seus termos. Como veremos à frente, no caso do mito individual do neurótico, a partir de um questionamento primordial sobre o desejo, sobre aquilo que o causa, toda a rede mítica é atualizada e imprime sobre sua vivência o caráter de uma gesta com o estatuto de mito. Portanto, o mito seria aquele discurso que diz do sujeito a partir da assunção de seu lugar como essencialmente dividido, a partir de sua Spaltung fundamental.

Ao assumirmos o valor do mito nas origens da assimilação estrutural de Lacan, deste projeto global de formalização iniciado pela revolução epistemológica da linguística moderna, buscamos extrair as consequências para a obra do psicanalista de seu primeiro modelo ter sido aquele pelo qual Lévi-Strauss extraiu da análise mítica. Ao longo deste capítulo, estamos acompanhado o quanto tal fórmula respondia aos anseios do projeto lacaniano, da inserção de uma formalização da psicanálise enquanto uma experiência da linguagem habitada por um sujeito (LACAN, S.III, p.276), mas neste tópico a questão toma outra inflexão. Em que medida a fórmula canônica do mito influenciou, nos mais diversos contextos, a concepção dos modelos, esquemas e grafos lacanianos, em outros termos, teriam as configurações destes sido marcadas pela fórmula canônica do mito enquanto um modelo de base dos demais modelos, um metamodelo (Cf. DUNKER, 2012). 
Dos modelos que podemos analisar como mais próximos ao da fórmula canônica, encontramos aquele presente no Seminário sobre "A carta roubada", na qual Lacan busca apresentar a incidência e insistência da cadeia significante nos determinantes subjetivos, outros termos, como a "ordem simbólica é constituinte para o sujeito, demonstrando numa história [conto de Poe] a determinação fundamental que o sujeito recebe do percurso de um significante" (LACAN, 1955, p.14). A partir da análise da história narrada por Poe, Lacan demonstra como em duas cenas sucessivas, formadas por dois pares de relações cada, e estruturalmente homólogas, há uma transformação das posições simbólicas da primeira para a segunda a partir do papel de um significante específico, no caso, a própria carta. Ao relacionar dois pares de relações, Lacan demonstra o valor das transformações entre as diferentes cenas na identificação dos significantes que determinam a vivência do sujeito, assim como diferentes posições levam a diferentes atos, recusas, cegueiras, enfim, a diferentes destinos (LACAN, 1955, p.34). Entretanto, se esta estrutura quaternária ainda se mostra por demais ligada à formalização de uma produção discursiva análoga à produção do sujeito, Lacan dela derivará uma rede combinatória, cujo intuito é demonstrar como certas transformações significantes, pela própria lógica da cadeia de linguagem, são impostas em detrimento de outras. Essa rede - cuja estrutura é reconhecida como próxima à análise de Lévi-Strauss sobre as organizações dualistas (LACAN, 1955, p.52) - ainda salienta a sobredeterminação simbólica imposta pelo valor significante da cadeia na qual o sujeito se encontra inserido. "Essa postulação da autonomia do simbólico", nos diz Lacan, "permite nos libertar de seus equívocos a teoria e pratica da associação livre em psicanálise" (LACAN, 1955, p.56).

Na mesma época desta análise de Lacan, ele forja esquema que demonstra de forma menos direta a inspiração da estrutura de Lévi-Strauss, a saber, o esquema L. Eis sua representação gráfica:

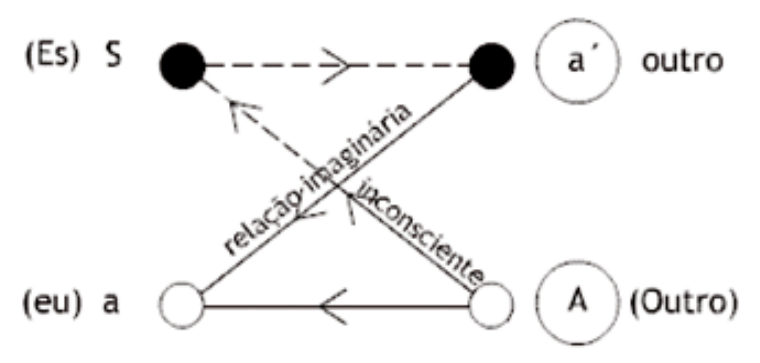


Construído e desenvolvido desde os primeiros anos de seu seminário, o esquema L busca explicitar o modo como se articulam, na constituição do sujeito e, consequentemente, no interior de uma análise, a dialética entre os registros do simbólico e do imaginário. Em constante tensão, estas duas modalidades de relação implicam mútuas imbricações importantes para formalizar a relação do sujeito com a linguagem: em linhas gerais, o esquema demonstra que a relação simbólica entre sujeito e Outro está bloqueada pelo eixo imaginário, entre eu e outro. O "muro da linguagem", aí formado, implica que o sujeito apenas recebe do Outro sua mensagem invertida e fragmentada ${ }^{29}$ (LACAN, S.II, p.308).

Como primeira extensão do modelo fundamental da estrutura quaternária, poderíamos nos questionar se não há ai um aspecto contingente, ou melhor, indagar se há uma necessidade na teorização de Lacan de que o esquema se constitua assim. A este respeito nos diz o psicanalista: "Uma estrutura quadripartite, desde o inconsciente, é sempre exigível na construção de uma ordenação subjetiva. O que é satisfeito por nossos esquemas didáticos" (LACAN, 1963, p.785). Mas, por que? Miller (1998, p.919), na esteira de Lacan, aponta para a incidência da estrutura duplicante do imaginário sobre o registro simbólico. Decerto, pelo esquema L e pela apresentação presente em $O$ mito individual do neurótico, esta posição se sustenta. Mas aqui nos questionamos se a equivalência de registros distintos e assimétricos da experiência não seria o mote do valor de meta-modelo da formulação da estrutura do mito sobre o conjunto da formalização lacaniana, em outros termos, não responderia tal modelo pela própria tensão entre uma ordem antropológica e uma histórica. Tomemos, para seguir no curso desta hipótese, o grafo do desejo.

Desenvolvido desde o Seminário $\mathrm{V}$, o grafo do desejo responde pela inscrição e dialética do desejo na relação do sujeito com o Outro. Entretanto, ele traz em seus determinantes uma série de articulações específicas acerca da regulação do desejo a partir da dinâmica da fantasia e da pulsão (LACAN, 1958, p.831). Tomemos sua forma:

${ }^{29}$ A título de curiosidade, Zafiropoulos (2004) relata uma cena da relação pessoal de Lacan com Lévi-Strauss, na qual o último haveria formulado a famosa sentença: o sujeito recebe do outro sua mensagem invertida. Nesta, o antropólogo exemplifica com o fato de que quando diz: ela é minha mulher, o que está implícito e que marca a posição do enunciador é a mensagem invertida, eu sou o homem dela. Este exemplo reverberará significativamente na obra lacanianaa 


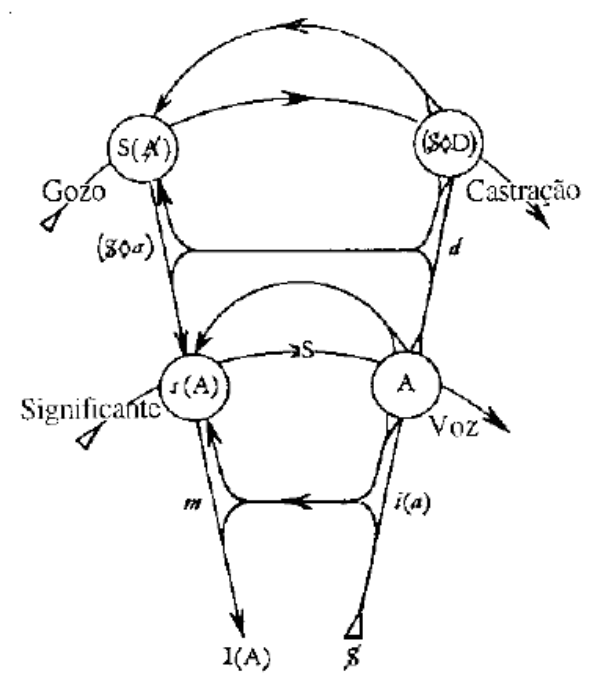

O grafo, como podemos notar, em sua forma completa, é estruturado por quatro significantes fundamentais por meio dos quais um circuito de relações se engendram. Seu valor é crucial para a revisão e maior contribuição da leitura da inserção do sujeito na dialética desejante constitutiva, assim como o modo pelo qual ela se realiza na dinâmica de um tratamento. A estrutura quaternária articula a relação entre dois pares de significante inscritos em cadeias distintas. O patamar de baixo, trata essencialmente da relação do sujeito com a linguagem, como ele se insere na cadeia de significantes que o determina. De caráter distinto é o patamar superior: neste encontramos a relação do sujeito com o gozo. Não há entre eles uma simples relação, mas, no interior da dinâmica proposta, Lacan demonstra como o gozo já se articula no interior da linguagem, assim como, pela via oposta, pode-se modificá-lo a partir de uma prática de linguagem (FINK, 2002, p.25).

Não tenho a pretensão de aqui defender, em suas minúcias, as modulações pelas quais cada modelo se insere na protoforma de inspiração lévi-straussiana. A construção de um modelo que toma a assimetria entre séries distintas, que assimile em si um impossível estruturante, perpassa ainda três outros exemplos: o modelo da teoria dos discursos, aquele impresso nas fórmulas da sexuação e a topologia dos nós borromeus.

No primeiro deles encontramos, como mencionamos, a tentativa de articulação sobre a estrutura dos laços sociais a partir de uma noção de discurso que extrapola a dimensão da oralidade. Ao conjugar uma sistema quaternário de lugares com a movimentação e circulação de quatro termos fundamentais, poderíamos nos questionar 
se sua forma não escaparia ao julgo da fórmula que aqui analisamos, justamente, por formar um circuito pretensamente circular. Entretanto, a dissimetria se encontra no cerne de sua formulação: cada discurso se constrói a partir de um modo de impossível distinto, ou seja, de incidências do real no laço social. Tais impossibilidades, estruturantes de cada discurso, são: impossível de governar, educar, analisar e fazer desejar (LACAN, S.XVII, p.164-5). A impossibilidade marcada na flecha da linha superior do modelo, faz as vezes, no patamar abaixo, de uma impotência de se comunicar os termos. Por esta leitura teríamos dois pares de relações separadas entre si, ligadas por uma impossibilidade de simples assimilação.

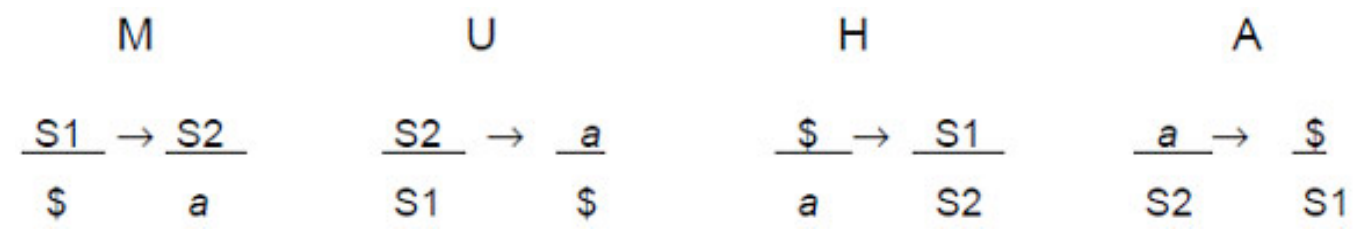

Saliento aqui outra leitura da dissimetria. Dunker (2012) sustenta que o modelo dos discursos implicam na coordenação de dois trios distintos, articulados em planos heterogêneos. O primeiro, tomando o discurso do mestre como paradigma, procederia da análise da inscrição do sujeito na articulação do desejo com a linguagem, tal como expresso no aforismo lacaniano "um significante representa o sujeito para outro significante”. Implicam-se nesta fórmula, as posições de agente, outro e sujeito: $\mathrm{S} 1 / \$ \rightarrow$ S2. Outra dimensão da fórmula seria a do gozo como inserido em uma dinâmica de produção a partir da relação entre os dois significantes aí implicados: S1 $\rightarrow$ S2/a. Esta leitura, aparentemente confirma nossa hipótese e a reposiciona frente ao poder de formalização que um modelo que assimila em si a diferença proporciona a uma teoria que busca dizer, escrever o real enquanto impossível, real este já inserido na fórmula canônica.

Para encerrar esta breve menção de uma hipótese decorrente de nossa premissa inicial, vejamos como se revela este metamodelo nas fórmulas da sexuação de Lacan.

De forma sintética, Lacan relê sua teoria da diferença sexual, com o objetivo de inscreve-la em um registro que não mais fosse da simples binaridade entre posições referidas ao significante fálico. No início da década de 70 , as fórmulas da sexuação surgem como um postulado lógico a assimilar duas formas de inscrição da posição sexual no inconsciente, a posição de homem e de mulher. Cada lado do diagrama, em 
seu lado superior, possui duas proposições que se definem por uma afirmação e uma negação da função fálica, uma inclusão e uma exclusão do gozo absoluto (não-fálico) (COPJEC, 1994 apud EVANS, 2006, p.183).

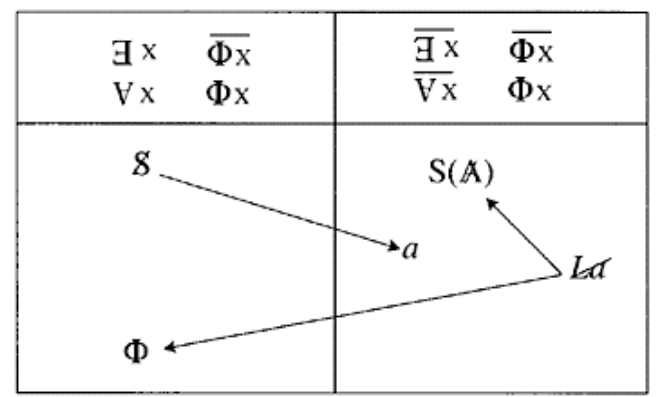

Importante notar que estas duas posições não apresentam uma relação simétrica, uma simples oposição, mas são diferenças diferentemente diferentes, inassimiláveis, que se opõe a partir de distintos modos de inscrição da lógica fálica e dos modos de gozo. Este seria, por nossa hipótese, no percurso da obra de Lacan o último modelo a se regular pela formalização propiciada pelo modelo da fórmula canônica do mito.

A partir do modelo topológico de formalização dos nós borromeus, o sistema que implicava uma dupla articulação entre planos heterogêneos, dará lugar a um sistema no qual cada elemento assimila em si uma dimensão distinta dos demais, cuja modulação se dirige por uma lógica própria. Entretanto, vale ressaltar que se são inscritos três registros básicos - real, imaginário e simbólico - a lógica quaternária inaugurada pela fórmula canônica, ainda se faz presente pela necessidade de entrevista por Lacan de um quarto termo, heterogêneo frente às características de cada registro, que sustentasse todo o sistema, seja o Nome do Pai, como quarto nó da nomeação de cada registro (S.XXII), seja como sinthome (S.XXIII).

A referência à topologia, neste contexto, já marcava presença há muito no pensamento de Lacan. Uma hipótese a ser analisada em trabalhos posteriores, seria a de considerar se as formas topológicas utilizadas na mesma época que os modelos aqui apresentados, não seguiriam, eles também, os princípios do modelo da fórmula lévistraussiana.

Como vimos no capítulo anterior, o antropólogo e matemático, Mauro de Almeida, ao revisar os termos da fórmula canônica, concebe que sua melhor compreensão seria a partir de uma representação topológica. Para isso, ele propõe a 
banda de Moebius como representação ideal das contradições impressas em um mito. Ora, essa mesma forma aparece na fala de Lacan em diversos momentos, assim como formas análogas, derivadas direta ou indiretamente daí, como a garrafa de Klein e o cross-cap. Cada uma com sua particularidade, inscrevem em suas superfícies, no que estas resguardam de contínuo, um ponto de instabilidade que subverte oposições fundamentais como dentro e fora, em cima e embaixo ${ }^{30}$. Ponto este que define cada forma. Teríamos aqui uma representação análoga do que seria o quarto elemento para a formula canônica, aquele cuja expressão se dá por uma dupla torção? Mais que buscarmos uma resposta, vejamos agora as especificidades do quarto termo para o projeto de formalização lacaniano.

\subsection{A dupla torção e sua função de enodamento da estrutura mítica}

Se até o momento analisamos as particularidades da fórmula canônica do mito a partir do valor da noção de mitema para a concepção lacaniana de significante, assim como da hipótese sobre as derivações de sua estrutura quaternária para a construção de diversos modelos de formalização encontrados na obra lacaniana, resta-nos ainda a análise de um ponto central para a fórmula lévi-straussiana, a saber, aquela representada pela dupla torção final.

Como referido, a inflexão da estrutura quaternária na análise do mito individual do neurótico, em sua conferência homônima, fez Lacan reconhecer a necessidade de uma revisão de todo o esquema pelo qual a tradição psicanalítica concebia a dinâmica do Édipo. Pois bem, se esta falava de um triângulo formado pelo complexo estruturante das relações das posições de pai, mãe e filho, resta saber qual seria o quarto termo, que “complementaria a tríade freudiana, no alinhamento da psicanálise com essa nova antropologia" (SIMANKE, 2002, p.489) assim como, sua necessidade para sustentação do sistema. Em $O$ mito individual, encontramos:

${ }^{30}$ Dunker acerca da noção de estrutura conjugadas nos modelos lacanianos: "A estrutura do inconsciente, formalizada a partir de um modelo linguístico cujo produto é a "lógica do significante" é sem dúvida a mais conhecida, mas poderíamos nos referir a estrutura do ato de fala, a partir do esquema "L", à estrutura do discurso, objeto do Seminário XVII e a estrutura topológica das relações entre demanda e desejo (o toro), da fantasia (o cross-cap), do sujeito (a banda de moebius) e da transferência (a garrafa de Klein)". (DUNKER, 2006) 
Tudo isso desemboca no quatuor mítico. Ele é reintegrável na história do sujeito e desconhecê-lo é desconhecer o elemento dinâmico mais importante da própria análise. Estamos aqui apenas destacando-o. Qual é esse quarto elemento? Pois bem, vou designá-lo hoje dizendo que é a morte. Pode-se perfeitamente conceber a morte como elemento mediador. (LACAN, 1953, p.42)

A morte neste escrito possui uma dupla incidência: em primeiro lugar, ela aparece nos dois momentos principais da gesta do Homem dos ratos - o plano do trabalho, a partir da relação com o pai cruel, impositivo, e com a identificação de ordem mortal que realiza com seu objeto de gozo. Por fim, o tema da morte surge a partir da dialética proposta pela metafisica hegeliana acerca da fenomenologia das relações humanas tipificada na alegoria da luta do senhor e do escravo. A morte possui aí um papel humanizante na relação do sujeito com seu semelhante. Lacan reconhece aí, em especial, na leitura kojèveana da fenomenologia de Hegel, um postulado fundamental para tratar da dialética subjetiva, cujo uso será revisto a partir do escrito que ora tratamos, assim como o reposicionamento da temática do narcisismo. Tomemos a continuidade de seu argumento:

Com efeito, é da morte, imaginada, imaginária que se trata na relação narcísica. É igualmente a morte imaginária e imaginada que se introduz na dialética do drama edipiano, e é dela que se trata na formação do neurótico - e talvez, até certo ponto, em algo que vai muito além da formação do neurótico, a saber, a atitude existencial característica do homem moderno. (LACAN, 1953, p.43)

A morte neste contexto, apresenta-se como a articulação imaginária em uma dialética simbólica. Ou seja, ela aparece como mediadora de uma dupla passagem: de um lado operando passagem da natureza para a cultura, ou seja, para a universalidade antropológica; de outro, ao situar a temática da morte no seio da atitude existencial do homem moderno, Lacan a inscreve na particularidade do momento histórico, realizando a passagem do antigo ao moderno. Mesmo papel que aí Lacan atribui ao pai. 
Antes de apresentar a síntese do quarto elemento como a morte, ele o designa como representando o desdobramento da função simbólica do pai. Para o psicanalista, isso se justificaria pelo fato de que, em uma "estrutura social como a nossa, o pai é sempre, por algum lado, discordante com relação à sua função, um pai carente, humilhado" (Ibidem, p.40). Portanto, aquele que encarna a posição do pai, teria em nossa sociedade uma impossibilidade estrutural de recobrir toda a função simbólica aí suposta. Esta seria um dos motivos pelos quais o complexo de Édipo, na modernidade, seria patologizante em sua essência. Diante de um pai insuficiente, carente, que não assume plenamente sua função simbólica, o sujeito responde desde o modo imaginário de relação: recobre a carência com a totalidade, com este outro pleno, diante do qual experiencia sua existência como nulificada, análoga à morte.

Eis o pai simbólico, o pai morto, aquele que pode responder absolutamente à sua função, aquele que, fora do laço social, fora da dialética desejante, produzida e produtora de faltas, carências, afirma seu lugar de modo autorreferente por um bíblico "Sou o que sou”. Entretanto, se o pai simbólico não está totalmente realizado em parte alguma, ele se configura como um elemento "constitutivo de todas as manifestações da condição humana, em especial, na vivência imediata do neurótico" (LACAN, 1953a, p.43). A este impensável, tão presente nos mitos e fantasias neuróticos, é que Freud se remete ao produzir seu próprio mito. A este respeito tomemos o comentário de Lacan:

Sua obra mais cara, com um êxito que lhe parecia uma performance, é Totem e Tabu, que nada mais é que um mito moderno, um mito construído para explicar o que permanecia em hiância em sua doutrina, a saber: Onde está o pai? Basta ler Totem e Tabu, mantendo simplesmente o olho aberto, para perceber que, se isso não é o que lhes digo, ou seja, um mito, é inteiramente absurdo. Totem e Tabu é feito para nos dizer que, para que os pais subsistam, é preciso que o verdadeiro pai, o pai singular, o pai único, esteja antes do surgimento da história, e que seja o pai morto. Mais, ainda: que seja o pai assassinado. E, realmente, como isso poderia ser pensado fora do valor mítico? Pois, que eu saiba, o pai em questão não é concebido por Freud, nem por ninguém, como um ser imortal. Por que é preciso que os filhos tenham, de certa forma, antecipado sua morte? E tudo 
isso, com que fim? Para, afinal de contas, interditarem a si mesmos o que se tratava de arrebatar a ele. Não o mataram senão para mostrar que ele é incapaz de ser morto. (LACAN, S.IV, p.215)

Ora, Lacan apresenta neste momento de sua obra o pai simbólico como uma necessidade da articulação simbólica, situada num "mais-além", que apenas pode ser acessada através de uma construção mítica (LACAN, S.IV, p.225). Portanto, o real em jogo em Totem e Tabu, que faz com que a experiência do assassinato se dê antes de a registrar simbolicamente, pode ser considerado um real antropológico, ponto de junção entre a dimensão estrutural e histórica, que o mito faria questão de circunscrever. Ao pai simbólico aqui tratado, podemos situá-lo como a primeira formulação do que seria o quarto termo da fórmula canônica do mito.

Entretanto, antes de seguir a via desta construção, façamos um parêntese para notar que se o pai simbólico é aquele que se inscreve a partir de um mito, ele não o é a partir de qualquer mito, pois como tanto na referência ao mito de Édipo quanto na realizada a Totem e Tabu, Lacan salientou que tal inscrição se insere em um dado momento histórico: a modernidade. Portanto, em uma época definida claramente por uma forma de laço social na qual uma construção como a imago do pai, e sua discordância fundamental, teria uma função e uma eficácia social particular. Eis uma diferença fundamental da leitura lacaniana para a leitura freudiana, qual seja, a relatividade do valor mítico. Vejamos as implicações desta tese para a teoria lacaniana do mito.

\subsection{A psicanálise e seus mitos: a relativização da universalidade de Édipo}

Ao buscar uma articulação entre os referenciais estruturais e históricos, Lacan retira do mito edípico o pretenso valor de universalidade normativizante, assim como de Totem e Tabu o de única narrativa fundadora da posição humana. Se ambos se dirigem a um questionamento sobre a posição do sujeito frente ao Outro, esta instância psicossocial globalizante da linguagem, as bases desse questionamento não são necessariamente universais (Cf. ZAFIROPOULOS, 2004, p.20). 
Desde o início de seu percurso pela psicanálise encontramos em Lacan uma tese social sobre declínio na modernidade do valor da posição do pai, de sua imago fundamental (Cf. LACAN, 1938). Este fato tem um valor central para o modo como o sujeito, inserido em um dado contexto histórico-cultural, articula suas questões, se inclui na matriz desejante constitutiva, cujo modelo fundamental é do complexo de Édipo. Entretanto, não há necessidade de que o que é apreendido como uma questão formulada na sociedade ocidental moderna, seja correspondente, ponto a ponto, aos questionamentos de outros povos. O grau de relativismo de Lacan, neste assunto, pode ser bem balizado a partir da seguinte citação:

A virtude da situação simbólica do Édipo, em um tratamento, [...] é verdadeiramente a chave - uma chave muito reduzida. Já lhes indiquei que havia, muito provavelmente, todo um molho de chaves. Talvez lhes faça um dia uma conferência sobre o que nos dá, a esse respeito, o mito dos primitivos - não direi os menores primitivos, porque não são menores, sabem muito mais que nós. Quando estudamos uma mitologia, a que, por exemplo, vai talvez aparecer a propósito de uma população sudanesa, vemos que o complexo de Édipo não é para eles senão uma piadinha. É um detalhezinho mínimo num mito imenso. O mito permite confrontar uma série de relações entre os sujeitos, de uma riqueza e de uma complexidade perto das quais o Édipo parece uma edição tão abreviada, que afinal, nem sempre é utilizável. (LACAN, S.I, p.104).

O reposicionamento do mito de Édipo, no interior de uma rede de mitos, se aproxima da proposta empreendida por Lévi-Strauss em $A$ estrutura dos mitos, quando este coloca lado a lado, o mito edípico e o mito ameríndio dos pueblo. Ao deslocar sua narrativa de uma versão única sobre o sujeito, Lacan demonstra não apenas a assimilação da lógica simbólica em seu pensamento, como a possibilidade de ressituar a articulação da leitura do mito individual pela psicanálise com a mitologia, extraída de campo.

Os mitos que perpassam a teoria psicanalítica não devem servir de matriz para a leitura dos mitos de outros povos, não se deve colonizar as possibilidades de 
interpretação de outros sistemas mitológicos, que sustentam, no coletivo, funções distintas, dos mitos presentes na estruturação da vivência sintomática da neurose na modernidade. Os mitos coletivos, se denunciam a divisão essencial do sujeito, demonstram, por sua vez, a "instalação em pé do homem no mundo", base de toda situação social no mundo (LACAN, S.IV, p.337): eles fornecem os significantes primordiais nos quais cada um pode reconhecer seu destino. Na modernidade, o mito teria perdido seu valor predominante de enlaçamento social, reproduzindo-se no âmbito individual este modelo de lidar com os impasses da sua relação com as bases de sua existência, com o sistema significante que determina sua experiência. Esta tese, também de extração lévi-straussiana, são bem assimiladas por Lacan:

É graças a seus mitos que o primitivo se acha aí dentro da ordem das significâncias. Ele tem chaves para todas as espécies de situações extraordinárias. Se ele se coloca em oposição declarada a tudo, alguns significantes o suportam ainda, os quais, por exemplo, lhe dizem exatamente a forma de punição que sua saída comporta, a qual pode produzir desordens. A regra lhe impõe seu ritmo fundamental. Quanto a nós, estamos reduzidos a permanecer muito medrosamente no conformismo, tememos nos tornar um pouquinho loucos logo que não digamos exatamente a mesma coisa que todo o mundo. É essa a situação do homem moderno. (LACAN, S.III, p.228)

A despeito da diferença central da função do sistema mítico, como bem reconhece Lacan, este salienta, à semelhança das teses de $A$ eficácia simbólica, que sua estrutura mítica permanece inalterada, que sua função de solução em uma situação fechada procede por uma articulação de recolocações do problema, de modo a dar expressão significante a este (LACAN, S.IV, p.366). Esta relativização da narrativa mítica frente a sua estrutura, permitiu ao psicanalista, como veremos, recolocar a ordem mítica de Édipo e Totem e Tabu de modo a diferenciá-los como mitos que respondem a questionamentos distintos, tese substancialmente distinta da sustentada por Freud. Para chegarmos a este ponto, voltemos às implicações do estatuto do quarto elemento, para a compreensão da justa posição da função do mito na constituição subjetiva. 


\section{O quarto elemento e seu estatuto de significante especial: Nome-do-Pai, Falo e}

$\mathbf{S}(\mathbf{A})$

Ao tomarmos a via da exploração das especificidades do quarto elemento, partimos do modo como ele incide sobre pensamento lacaniano desde $O$ mito individual: encontramos aí a indicação da inserção da morte e do pai simbólico nesta posição. Estes dois elementos, de valor humanizante e estruturais, respondem, como expresso em Totem e Tabu, pela origem da ordem significante e da lei que esta articula. O pai simbólico, que fora assassinado antes do princípio do tempo histórico, representa, portanto, aquele que sustenta a possibilidade de inscrição de um sujeito na ordem da linguagem, aquele que, desde um lugar estruturante da vivência deste sujeito, permitiu a estabilidade e ordenação das significâncias do mundo, ou ainda, aquele que funda a cadeia de significantes na qual o sujeito se posiciona subjetivamente. Sobre o papel desta cadeia, tomemos as palavras de Lacan:

Se o que Freud descobriu, e redescobre com um gume cada vez mais afiado, tem algum sentido, é que o deslocamento do significante determina os sujeitos em seus atos, seu destino, suas recusas, suas cegueiras, seu sucesso e sua sorte, não obstante seus dons inatos e sua posição social, sem levar em conta o caráter ou o sexo, e que por bem ou por mal seguirá o rumo do significante, como armas e bagagens, tudo aquilo que é da ordem do dado psicológico. (LACAN, 1955, p.34).

Esta cadeia significante é sustentada portanto, por um elemento discordante dos demais. Tal como vimos na fórmula canônica do mito, ao trazer o pai simbólico como o quarto termo, Lacan marca uma posição estrutural peculiar. Entretanto, como vimos, essa posição não pode ser apreendida na imediaticidade da vida subjetiva, ela circunscreve um estruturante da experiência que depende da lógica do mito para dar formulação discursiva. Em 1956, em intervenção a uma fala de Lévi-Strauss, Lacan retoma sua leitura da fórmula canônica, assim como da função exercida por esse último termo. Nas palavras do psicanalista:

Consegui formalizar estritamente o caso [homem dos ratos] segundo uma formula dada por Claude Lévi-Strauss, pela qual se verifica que um a, associado de inicio a um b, enquanto 
um c está associado a um d, troca com ele de parceiro na segunda geração, mas não sem que subsista um resíduo irredutível sob a forma da negativação de um dos quatro termos, que se impõe como correlativa à transformação do grupo, no que se lê o que chamaria de signo de uma espécie de impossibilidade da total resolução do problema do mito. De sorte que o mito estaria aí para nos mostrar o equacionamento, sob uma forma significante, de uma problemática que tem por si só de deixar necessariamente algo em aberto, que responde ao insolúvel significando a insolubilidade, com sua saliência encontrada em suas equivalências, que fornece (essa seria a função do mito), o significante do impossivel. (LACAN, 1956, p.90-1 - grifo meu)

A partir do modelo de transformações míticas de Lévi-Strauss, pela leitura de Lacan, teríamos, portanto, um modo de articular pela via do significante uma questão insolúvel, impossível. A articulação daí derivada, teria como elemento estruturante um significante especial, este que Lacan denominou o significante do impossível. Ora, não teria o pai simbólico, que como vimos foi o primeiro modo de formular o valor do quarto elemento, este estatuto? Sobre seu papel frente a impossibilidade Lacan nos diz:

A essência do principal drama introduzido por Freud [Totem e Tabu] repousa sobre uma noção estritamente mítica, na medida em que ela é a própria categorização de uma forma do impossível, até mesmo do impensável, a saber, a eternização de um só pai na origem, cujas características consistem em ter sido morto. E, por que, senão para conservá-lo? (LACAN, S.IV, p.215)

O pai morto, portanto, desponta como um destes tipos de significante que funcionam como articuladores da cadeia simbólica. Este significante, entretanto, possui uma outra característica que lhe dota de um estatuto privilegiado: diferente dos demais significantes, este ele possui um valor zero de significação próprio. Mesmo que não signifique nada "ele carrega, certamente, toda a ordem das significações Se existe algo dessa natureza, em nenhum lugar é tão sensível quanto no mito" (LACAN, S.IV, p.261). 
Do ponto de vista formal, encontramos uma série de versões do que seria esse tipo especial de significante, significantes de exceção (ZAFIROPOULOS, 2006, p.234) que estrutura toda uma cadeia: temos aí, o significante do nome-do-pai, o significante fálico, o significante da falta no Outro $[S(\mathcal{A})]$, etc. Se cada um possui uma incidência diferente sobre a teoria da constituição do sujeito, eles não deixam de se inscrever na função de estruturação de uma cadeia a partir de seu estatuto especial, cujo resultado é servir de operador privilegiado de significações. Mais, ainda: esses significantes apontam que todo modelo de um sistema de linguagem, significante, como o é a fórmula canônica do mito, deve representar uma inconsistência estrutural no Outro, própria de uma falha que permite ao sujeito de desejo emergir e aí se inscrever, em toda dialética simbólica pressuposta pela dinâmica do desejo.

Entretanto, fora do âmbito conceitual encontramos ainda uma série de menções sobre elementos que realizam essa modulação significante, como, p.ex., na trama da carta roubada, onde a própria carta em sua circulação realiza a função de distribuir posições diferenciais em uma cadeia simbólica. Em outros termos ela dá materialidade à falta constitutiva no Outro. Assim como vimos no capítulo anterior, no caso do mito de Édipo, Oidipous no lugar da resposta ao enigma, tomaremos à frente as incidências de tal regulação do significante no caso freudiano do homem dos ratos. Por ora, vejamos como os três significantes acima referidos se inserem nesta lógica estruturante do quarto elemento.

Ao iniciar a nomeação deste "significante do impossível" pela vertente do pai simbólico e da morte, Lacan tratava de assinalar que um dos elementos constitutivos do fato humano, está locado na ideia de que o pai, enquanto função simbólica, nada mais é que um significante privilegiado, como o é, nos estudos linguísticos a noção de nome. A esse respeito, Lacan nos diz:

Aquilo que funda a própria significação, a fala como ato, é alguma coisa que se coloca como conferindo autoridade à lei. Aqui chamamos de lei aquilo que se articula propriamente no nível do significante, ou seja, o texto da lei. Não é a mesma coisa dizer que uma pessoa deve estar presente para sustentar a autenticidade da fala e dizer que há alguma coisa que autoriza o texto da lei. [...] Com efeito, o que autoriza o texto da lei se 
basta por estar, ele mesmo, no nível do significante. Trata-se do que chamo de Nome-do-Pai, isto e, o pai simbólico. Esse é um termo que subsiste no nível do significante, que, no Outro como sede da lei, representa o Outro. É o significante que da esteio à lei, que promulga a lei. Esse é o Outro no Outro. (LACAN, S.V, p.152) $)^{31}$

O significante Nome-do-Pai é, portanto, um termo especial para a produção de significações no interior da inscrição de um sujeito na ordem significante. Ele responde pelo lugar de uma falta, impossível de ser simbolizada fora da referência mítica, a saber, o lugar onde o desejo se constitui, se engendra. No modelo lacaniano da metáfora paterna, o Nome-do-Pai, aparece como um articulador do desejo materno, desejo que inscreve a criança na dinâmica das faltas.

$$
\frac{\text { Nome-do-pai }}{\text { Desejo da mãe }} \cdot \frac{\text { Desejo da mãe }}{\text { Significado para o sujeito }} \rightarrow \text { Nome-do-pai }\left(\frac{\mathrm{A}}{\text { Falo }}\right)
$$

A experiência de que o outro materno deseja da criança algo além da criança ela mesma, experiência, portanto, de uma falta primordial, inscreve na dinâmica da relação com o outro e na própria vida subjetiva, um enigma. O Nome-do-Pai expressa, portanto, esse lugar ideal, terceiro, através do qual o desejo pode encontrar sua realização impossível, e o enigma, sua resposta. No interior dessa dinâmica, um objeto se destaca como um significante do tipo que ora analisamos, este é justamente o falo.

$\mathrm{Na}$ retomada dos termos do Édipo, matriz da constituição subjetiva, Lacan enfatiza, Lacan enfatiza a necessidade de que um quarto termos seja inserido nessa dinâmica. O falo responde em seu modelo dos três tempos do Édipo como o objeto simbólico que daria tratamento significante à falta. Se o Nome-do-Pai, se resume a um lugar a partir do qual se pode metaforizar a aquilo que falta à mãe, expresso no fato dela ser desejante, o falo encontra na construção lacaniana o estatuto de um objeto simbólico que se justifica pela sua função na dialética do desejo. $O$ falo, em sua vertente simbólica, se relaciona justamente como o "elemento simbólico da troca, nos termo de

31 Ainda no Seminário VII, encontramos a seguinte aproximação entre o Nome-do-Pai e a função paterna: “A única função do pai, em nossa articulação, é a de ser um mito, sempre e unicamente o Nome-do-Pai, isto é, nada mais do que o pai morto, como Freud no-lo explica em Totem e Tabu. Mas ;e claro que para que isto seja plenamente desenvolvido, é preciso que a aventura humana, nem que seja em esboço, seja levada a seu termo, ou seja, que seja explorada a zona em que Édipo avança após ter dilacerados os olhos." (LACAN, S.VII, p.392). 
Lévi-Strauss, ou como o símbolo da simbolicidade - significante dos significantes naquilo que todo símbolo pressupõe a morte da coisa, e o desejo pela coisa abolida" (BORCH-JACOBSON, 1994, p.279). Acerca deste estatuto, tomemos as razões de Lacan:

O falo é um significante, e como tal dá a razão do desejo (na acepção em que esse termo é empregado como "média e razão extrema" da divisão harmônica). [...] Que o falo seja um significante impõe que seja no lugar do Outro que o sujeito tem acesso a ele. Mas, como esse significante só se encontra aí velado e como razão do desejo do Outro, é esse desejo do Outro como tal que se impõe ao sujeito reconhecer, isto, é, o outro enquanto ele mesmo é um sujeito dividido pela Spaltung significante. (LACAN, 1958, p.700).

O falo, portanto, como significante do desejo do Outro, inscreve na cadeia significante os pontos de significação desse desejo. Desse modo, a criança não apenas supõe um lugar terceiro, como imbui aquele que assume esse lugar, o pai simbólico, de portar o falo, objeto do desejo. Tomando como referência os termos do Édipo, poderíamos assinalar o falo, em sua expressão simbólica, como a tentativa impossível de dar uma resposta satisfatória ao desejo do Outro. Por esta via, teríamos a seguinte configuração do sistema quaternário: em uma primeira cena (Criança) : (Mãe), e na segunda cena Ausência/Desejo da Mãe : Falo simbólico (como tentativa impossível de resposta ao desejo)/Nome-do-Pai (como significante que articularia logicamente tal desejo). Sendo que a primeira cena somente é formulada a posteriori, retroativamente ao surgimento deste segundo momento. Esta configuração encontraria um modelo análogo na forma como relemos o mito de Édipo no capítulo anterior, posto que na terceira posição teríamos o lugar do enigma, do questionamento impossível de justa resposta, e na quarta posição o lugar do impossível de ser expresso, da resposta que está além e aquém da questão.

No drama do mito individual do neurótico, assim como na estrutura sintomática da fobia - para citar os campos nos quais Lacan mais se dedicou à temática do mito, caso Hans e do Homem dos Ratos - todo o sistema se articula em torno deste enigma sobre este objeto do desejo. Ao tomá-lo como um significante central na 
construção na dialética desejante, duas facetas se impõe: a primeira é a de inscrever na dinâmica de "ter e ser o falo" uma primeira versão da teoria da identificação sexual em Lacan, dado que o efeito centrípeto do significante fálico imprime sobre cada sexo um “padrão de manifestações ideais ou típicas de comportamento" (LACAN, 1958, p.701); a segunda é a de servir de mola para a cadeia significante, operando a constante reinscrita da falta, de vez que esse termo, como puro significante, apenas indica a inadequação, a hiância entre o desejo do Outro e qualquer realidade que se busque objetivá-lo. Na esteira dessa impossibilidade de plena objetificação, Lacan constrói através do significante da falta no Outro, $S(\AA)$, uma diferente versão deste "significante do impossível". 32

Como vimos no modelo do Grafo do Desejo, é na cadeia significante superior, que se articula em termos da Pulsão, que Lacan situou este significante. Ora, se ele expressa uma função, é justamente a de que a resposta à questão "o que quer o Outro de mim?", é uma resposta impossível, que não há um significante que diga da totalidade do Outro, um Outro do Outro (LACAN, 1960, p.833). Entretanto, ao assinalar um significante para dar expressão simbólica prioritariamente à inconsistência no Outro, Lacan nos introduz uma distinta incidência da relação do sujeito com a falta. Em seus termos:

Quanto a nós, partiremos do que a sigla $S(\mathbb{A})$ articula por ser antes de tudo um significante. [...] Esse significante, portanto, será aquele para o qual todos os outros significantes representam o sujeito: ou seja, na falta desse significante, todos os demais não representariam nada. Já que nada é representado senão para algo. [...] ora, estando a bateria dos significantes, tal como é, por isso mesmo completa, esse significante só pode ser um traço que se traça por seu círculo, sem poder ser incluído nele. Simbolizável, pela inerência de um (-1) no conjunto dos significantes. Como tal, ele é impronunciável, porem não sua

32 Acerca do caráter fugidio do objeto do desejo, tomemos a seguinte citação de Lacan: "Aquilo a que os conduz o que lhes ensino, e que já está no texto de Freud, mascarado sob o mito de Édipo, é que esses termos, o desejo e a lei, que parecem colocar-se numa relação de antítese, são apenas uma e mesma barreira, para nos barrar o acesso à Coisa. Ao desejar, enveredo pelo caminho da lei. É por isso que Freud relaciona o inapreensível desejo do pai com a origem da lei. [...] Que normatizem meus objetos, quer não, enquanto eu desejo nada seu sobre aquilo que desejo.” (LACAN, S.X, p.93). 
operação, pois ela é o que se produz toda vez que um nome próprio é pronunciado. Seu enunciado iguala-se a sua significação. (LACAN, 1960, p. 833)

Lacan, ao relacionar o escopo de funcionalidade desse significante da teoria do nome, aproxima-se dos outros dois significantes especiais que analisamos acima. $\mathrm{O}$ nome, como um shifter, não possui uma significado previamente partilhado. Diferente do significante "livro", um nome é um tipo de significante que, assim como os pronomes, designam seu objeto, não pelo enunciado, mas no justo momento de sua enunciação. É a falta de uma consistência no Outro, de uma instância simbólica que se sustente fora de uma referência à dialética desejante, que introduz o $S(A)$ como aquele que emerge de como estruturante na relação entre sujeito e a linguagem.

No justo momento de apresentação deste significante, Lacan atina-se à necessidade de se diferenciar este termo estruturante do simbólico daquele que LéviStrauss, em comentário sobre Mauss, designou como mana. Este, como vimos, é responsável por assimilar em si a diferença, por responder à indeterminação e à ambiguidade própria ao simbólico, tal qual um significante zero. Se o mana foi essencial para a construção do modelo de Lévi-Strauss, posto que ele responde por uma função próxima à do shifter, Lacan fará questão de situar o $\mathrm{S}(\mathbb{A})$ como um significante da falta desse símbolo zero. Por mais que encontremos no conjunto simbólico uma pletora de determinações significante, ele apenas pode se estruturar pela falta de um, por aquele que, na enunciação, escapa aos efeitos de significação. A constante abertura do Outro, cujo efeito é perpetuar a dimensão enigmática do desejo aí locado, se sustenta, conforme Lacan, na ex-sistência de um princípio de irrazão, tal qual representada em seu potencial de significação pelo número imaginário $\sqrt{ }-1$. Eis o que justificaria a colocação deste termo na cadeia relacionada ao gozo, no grafo do desejo. Acerca dessa relação, Lacan nos diz:

Aquilo a que é preciso nos atermos é que o gozo está vedado a quem fala como tal, ou ainda, que ele só pode ser dito nas entrelinhas por quem quer que seja sujeito da Lei, já que a lei se funda justamente nessa proibição. (LACAN, 1960, p.836) 
Dos três significantes especiais que aqui tratamos, encontramos diferentes modulações de uma potencial expressão do que o quarto termo presente na fórmula canônica representaria a partir da assimilação lacaniana deste modelo. Para o psicanalista, os três elementos representam a possibilidade de sustentação de uma articulação significante frente a um enigma original. A inserção do sujeito na dialética desejante, o questionamento sobre o desejo do Outro, responde pela emergência constitutiva do sujeito, ele próprio, como desejante ${ }^{33}$.

Se a concepção lévi-straussiana do mitante extraia-lhe o estatuto de sujeito, posto que sua função seria simplesmente a de veicular a uma combinatória significante pré-subjetiva, para Lacan o sujeito se articula na justa medida em que formula sua questão, em que busca articular esse enigma. O mito, portanto, antes de servir de resposta, explicação, metaforiza em suas produções a inconsistência deste Outro, condição de possibilidade para a constituição do sujeito. O mito, em outros termos, antes de responder, reinscreve a questão em sua hiância fundamental, faz emergir por seu percurso a dimensão do sujeito. Eis seu valor para a teoria da neurose.

Ao importar de Lévi-Strauss a noção de mito individual do neurótico, Lacan assimila a noção de que a estrutura do mito, como instância significante, precede à natureza daquele que veicula, mas reinterpreta, como vimos, a questão fundamental a partir de uma filosofia da história, na qual a dialética desejante tem um papel central. Se todo mito procede de uma questão impossível, insolúvel, podemos ver que a produção individual do neurótico, trata do momento constitutivo deste como sujeito. As modulações destas questões, sobre o desejo do Outro, respondem pelas próprias segmentações das particularidades, ou dos tipos clínicos da estrutura neurótica (neurose obsessiva, histeria e fobia). Observemos esta cita de Lacan:

$\mathrm{O}$ mito individual reproduz em menor escala este caráter fundamental do desenvolvimento mítico, onde quer que o possamos captar de modo suficiente. Ele consiste, em suma,

33 "Quaisquer que sejam os complexos motivos dos pais, eles funcionam, de uma forma muito direta, como a causa da presença física da criança no mundo. Esses motivos continuam a agir sobre a criança após o seu nascimento, sendo responsáveis, em parte, pelo seu advento enquanto um sujeito dentro da linguagem. Nesse sentido, o sujeito é causado pelo desejo do Outro. É possível compreender tal afirmação como uma descrição da alienação em termos do desejo, não apenas em termos de linguagem, embora o desejo e a linguagem sejam somente a urdidura e a trama do mesmo tecido; a linguagem é permeada pelo desejo e o desejo inconcebível sem a linguagem, e feito da própria matéria-prima da linguagem" (FINK, 2002, p.72). 
em enfrentar uma situação impossível através da articulação sucessiva de todas as formas de impossibilidade da solução. É nisso que a criação mítica responde a uma questão. Percorre o ciclo completo do que se apresenta ao mesmo tempo como abertura possível e como abertura impossível de se tomar. Fechado o circuito, algo se realizou, significando que o sujeito foi posto no nível da questão. (LACAN, S.IV, p.338)

É justamente neste movimento de percorrer um ciclo em torno de uma questão fundamental, que os três significantes que tratamos são introduzidos, como versões da falta e do impossível por ela impressa. Entretanto, devemos aqui apreender que a temática do impossível, assim como das bases estruturantes do sistema simbólico terão uma revisão no ensino de Lacan, que repercutirá em sua interpretação do fenômeno mítico. Nesta via, uma questão nos guiará: a inserção do real e a releitura do valor da formalização linguística pode em alguma medida nos auxiliar a uma mudança de perspectiva sobre os termos da fórmula canónica do mito, dando-nos as bases para indicar aqui, a partir dos desenvolvimentos da psicanálise lacaniana, uma possível via de operação de um projeto de retomada da antropologia estrutural, como um "Retorno a Lévi-Strauss"?

\subsection{Inflexões da temática do impossível sobre a ordem do real: o objeto a}

A década de 60 marca uma inflexão no conjunto da obra lacaniana, e consequentemente sobre a concepção do papel do mito em sua economia conceitual, pela inserção de uma série de desenvolvimentos sobre as incidências próprias da ordem do real na experiência analítica e nos princípios da constituição subjetiva. A ênfase na lógica significante, cujos efeitos para o entendimento do mito expusemos acima, dá lugar a uma modulação do potencial expressivo do mito, como articulação de um impossível, que se aproxima de temáticas articuladas $\mathrm{p}$, como a causa do desejo, a fantasia e o campo do gozo. Vejamos detidamente como este cenário se estabelece no pensamento lacaniano.

Como tratamos acima, ao revisar as bases do complexo de Édipo a partir de $O$ mito individual, Lacan reforçou o papel do significante, e seu valor estrutural, para a 
determinação do sujeito. O Édipo, antes de ser fruto tão somente de experiências primitivas da criança, constitui-se como uma encruzilhada estrutural pela qual são dadas as coordenadas simbólicas da inscrição do sujeito em uma dialética desejante. Neste sentido, Totem e Tabu também se insere como uma matriz da origem necessária das relações entre desejo e lei, posto que são duas dimensões da "mesma coisa" (LACAN, S.VII. p.361). O que está prioritariamente aí em causa é a função do pai como sustentáculo da cadeia simbólica, como vemos na citação de Lacan:

Quanto ao pai que Édipo conheceu, este, só é, muito precisamente, como o mito de Freud o indica, o pai uma vez morto. E igualmente aí, como já lhes disse mil vezes, que está a função do pai. A única função do pai, em nossa articulação, é a de ser um mito, sempre e unicamente o Nome-do-Pai, isto é, nada mais do que o pai morto, como Freud no-lo explica em Totem e Tabu. Mas é claro que para que isso seja plenamente desenvolvido, é preciso que a aventura humana, nem que seja em esboço, seja levada a seu termo, ou seja, que seja explorada a zona em que Édipo avança após ter-se dilacerado os olhos. (LACAN, S.VII, p.362)

Por essa matriz, o impossível, equacionado em uma expressão significante no mito, é extraído predominantemente da hiância entre a determinação simbólica e a capacidade do sujeito de apreender seus fundamentos. Neste meio, encontramos, por outro lado, a dinâmica significante estabeleceu os pilares de entendimento do mito. Entretanto, com a introdução da temática da causalidade, em especial no que concerne ao campo do desejo - expresso por aquele que Lacan reconhece como seu único conceito criado, a saber, o objeto causa do desejo, objeto $a$ - a interpretação sobre o mito sofre uma mudança de ênfase. Doravante, o mito será progressivamente associado á relação do sujeito com esse objeto fantasmático. Após fazer o uso metodológico de um mito, no seminário VIII, para tratar da natureza desse objeto, ele reforça no seminário X seu valor de reposicionar a leitura de Lévi-Strauss. Em seus termos:

Essa interrogação — vocês sabem disso há muito tempo, porque é a mesma que estou sempre renovando sob múltiplos ângulos — concerne ao status do objeto como objeto 
do desejo. Tudo o que diz Claude Lévi-Strauss sobre a função da magia e a do mito tem seu valor, desde que saibamos que se trata da relação com o objeto que tem status de objeto do desejo. Esse status, admito, ainda não está estabelecido, e a questão é justamente fazê-lo avançar durante este ano, por meio da abordagem da angústia. (LACAN, S.X, p.47)

Esta mudança de ênfase é justamente a que justifica observações pertinentes como a de que os mitos produzidos nas teorias sexuais infantis são marcados pela onipresença dos objetos da pulsão, objetos parciais que circundam, tentam capturar o objeto causa de desejo, em especial o olhar e a voz (LACAN, S.XII, p.311). Esta inflexão leva à retomada das incidências do falo na constituição do sujeito, a partir de sua função perante o gozo.

O falo é o significante fora do sistema e, em síntese, o significante convencional para designar o que é radicalmente foracluído do gozo sexual. Se falei em foraclusão, justificadamente, para designar alguns efeitos da relação simbólica, e aqui que convém designar o ponto em que ela não é passível de revisão. Acrescentei que tudo que é recusado no simbólico reaparece no real, e é por isso mesmo que o gozo é absolutamente real, porque, no sistema do sujeito, ele não é simbolizado nem simbolizável em parte alguma. Dai a necessidade do mito que encontramos enunciado por Freud e que não se assemelha, estritamente, a nenhum mito conhecido da mitologia (LACAN, S.XVI, p.311).

A apresentação que Lacan faz aqui de Totem e Tabu, enquanto mito, o inclui como responsável por propiciar uma articulação simbólica desse gozo inapreensível, impossível de ser simbolizado, e mesmo de ser discriminado. "O Pai primevo do mito", continua Lacan, “seria aquele que confunde todas as mulheres em seu gozo.”(Ibidem). Então o psicanalista nos revela um princípio importante de sua apropriação do mito: esta leitura, da indiscernibilidade do gozo aí implicado, é extraída de uma análise sobre a forma mítica do enunciado, ou seja, da indeterminação do local onde se situa o gozo no contexto da horda primeva. Antes de marcar, portanto, uma relação intima com a 
lógica da fala e seus efeitos de enunciação, com seus efeitos metodológicos para a apropriação de sua lógica simbólica, o mito passa a ser lido por Lacan. Lido exatamente naquilo que lhe é permitido escrever de um gozo impossível de ser simbolizado. Mas voltemos um passo, antes de trilharmos esta via.

\section{O gozo como medida de distinção entre Édipo e Totem e Tabu}

Enquanto representam a fundação do mundo simbólico, ou seja, as origens da lei da linguagem, do sistema significante, Édipo e Totem e Tabu respondem pela inscrição de uma falta primordial e da diferença fundante deste sistema discreto. Mas, ao analisá-los como formas de expressão de um gozo específico, Lacan buscará em cada um, no modo como formulam suas gestas, as particularidades da posição do gozo veiculado em cada um, assim como sua relação com a lei. Por esta via, como vimos acima, Lacan conceituará a distância entre estes dois mitos, historicamente assimilados, se não identificados. A partir do seminário XVII, Lacan situará a distância de ambos da seguinte maneira:

Parece-me impossível - não é inútil eu esbarrar desde o começo nessa palavra - não captar a esquize que separa o mito de Édipo e de Totem e Tabu. Mostro minhas cartas de imediato. É que o primeiro foi ditado a Freud pela insatisfação da histérica, o segundo, por seus próprios impasses. Do menino, da mãe ou do trágico da passagem do pai para o filho - passagem de que, senão do falo? -, de tudo isso que serve de estofo ao primeiro mito, não há nenhum vestígio no segundo. Nele, Totem e Tabu, o pai goza - termo que é velado pelo poder no primeiro mito. O pai goza de todas as mulheres, até ser abatido pelos filhos, sem que estes tenham chegado a nenhum entendimento prévio, de modo que nenhum deles sucede ao pai em sua glutonaria de gozo. O termo se impõe pelo que acontece em vez disso - os filhos o devoram, ficando cada um apenas com uma parte, necessariamente, e, por isso mesmo, o todo constitui uma comunhão. (LACAN, S.XVIII, p.148) 
O mito de Édipo, como bem lembra Lacan, foi reconhecido em sua função generalizadora de um drama individual, a partir dos questionamentos freudianos acerca da particularidades do desejo histérico. A lei, na justa medida em que barra o gozo, aparece desde o começo da narrativa, analisada aqui em sua derivação trágica. O mito aí impõe que, para ter acesso ao gozo da mãe, Édipo deve se submeter a uma condição: assassinar seu pai (LACAN, S.XVII, p.113). A lei que regula a hierarquia real, por sua vez, responde a um gozo êxtimo aos personagens do mito, o gozo do povo tebano. Édipo demonstraria que, se de início, inocentemente, ou inconscientemente realiza seu destino ao matar seu pai, posteriormente, na tentativa de livrar seu povo da peste, enfrenta uma figura, a esfinge, armado com um saber que almeja o estatuto de verdade. Se Édipo neste embate alcança alguma verdade, ainda que semi-dita, ela é a de que seu gozo é incompatível com a lei que regula a Pólis. A busca de um saber plenamente verdadeiro, portanto, traria como condição um gozo transgressivo, fato que podemos conceber a partir do modelo de discurso da histeria, tal qual proposto por Lacan.

Totem e Tabu, por outro lado, apresenta um pai impossível de ser pensado, que goza desde o princípio de todas as mulheres. Neste mito, que Lacan passa a designar como "meio torto", aparentado de uma "palhaçada darwiniana" (LACAN, S.XVII), o gozo absoluto aparece como original daria lugar à lei. A função estrutural deste mito escrito, seria apontar para esse personagem impossível, cuja psicologia transcende os limites da tragédia. Nas palavras do psicanalista:

Tal como se enuncia, não mais no nível do trágico, com toda a sua leveza sutil, mas no enunciado do mito de Totem e Tabu, o mito freudiano é a equivalência entre o pai morto e o gozo. Eis o que podemos qualificar com a expressão operador estrutural. Aqui, o mito se transcende por enunciar, na qualidade de real - pois este é o ponto em que Freud insiste -, que isso aconteceu realmente, que é o real, que o pai morto é aquele que tem o gozo sob sua guarda, e de onde partiu a interdição do gozo, de onde ela procedeu. Que o pai morto seja o gozo, isto se apresenta a nós como sinal do próprio impossível. E é nisso mesmo que reencontramos aqui os termos que defini como aqueles que fixam a categoria do real, na medida em que ela se distingue radicalmente, no que articulo, do simbólico e do 
imaginário - o real é o impossível. Não na qualidade de simples escolho contra o qual quebramos a cara, mas de escolho lógico daquilo que, do simbólico, se enuncia como impossível. É daí que surge o real. Aí reconhecemos, com efeito, para além do mito de Édipo, um operador estrutural, aquele chamado de pai real. (LACAN, S.XVII, p.116)

O Pai da Horda primeva, portanto, é o pai em causa no complexo de castração, aquele pai que sustenta o gozo e, por essa via, impõe uma interdição a todos que procuram o mesmo gozo. A presença desse termo, imprime sua necessidade e marca: ao se configurar como um mito escrito, ou seja, uma contradição de termos, poderíamos questionar sobre sua validade de fenómeno mítico, posto que este se definiria por sua presença em um conjunto de variantes em torno de um núcleo central, no entanto, ao apresentar o pai impossível, agora, lido como real, Totem e Tabu se aproxima da estrutura da neurose obsessiva. É patente que este mito surja na obra freudiana, de forma próxima ao período em que Freud se deteve particularmente sobre a especificidade da neurose obsessiva, a saber, no fim dos anos 1910. Em tese, todo drama obsessivo nos daria uma versão deste mito freudiano. Em Lacan, temos as seguintes palavras:

E curioso que tenha sido preciso eu esperar este momento para poder formular uma assertiva assim, qual seja, que Totem e Tabu é um produto neurótico, o que é absolutamente incontestável, sem que por isso eu questione, em absoluto, a verdade da construção. É nisso, aliás, que ela é testemunha da verdade. Não se psicanalisa uma obra, menos ainda aquela de Freud, não é? Nós a criticamos e, longe de uma neurose tornar suspeita a sua solidez, é isso mesmo que a consolida, no caso. É ao testemunho que o obsessivo oferece de sua estrutura, no que da relação sexual se revela impossível de formular no discurso, que devemos o mito de Freud. (LACAN, S.XVIII, p.150-1 - grifo meu). 


\section{Lalangue e a possibilidade de releitura da fórmula canônica do mito}

A possibilidade de inscrever na teoria psicanalítica a distinção entre seus dois mitos fundadores, surge da própria distância tomada por Lacan do campo da linguística e da antropologia, no que concerne à função da linguagem. Como vimos, para o psicanalista, antes de servir à comunicação, a linguagem sustentada por um sujeito que fala, imprime neste sua própria divisão constitutiva, a saber, aquele que surge da hiância entre o que ele enuncia e sua enunciação, ou seja, o fato de se posicionar em sua própria fala. A psicanálise, antes de considerar uma linguagem sem sujeito, toma-a como uma linguagem habitada por um sujeito, que a tortura e que nela tropeça. Nesta via, a psicanálise, diferente da linguística, considera a linguagem como um produto do inconsciente, como uma órgão sobre o qual os linguistas realizaram uma anatomia minuciosa, mas sobre o qual pouco disseram de seus efeitos sobre um sujeito. Esta concepção repercute na visão lévi-straussiana do mito, como comenta Lacan:

Talvez eu deva acrescentar que o mito, na articulação de Lévi-Strauss rejeita tudo o que tenho promovido da instância da letra no inconsciente. Ele não opera pela metáfora, nem tampouco por qualquer metonímia. Não condensa, explica. Não desaloca, aloja, mesmo que modifique a ordem das tendas. (LACAN, 1970, p.409)

O mito, portanto, para Lévi-Strauss, não realizaria a operação metafórica de sustentar um significante que representasse um sujeito para outro significante. Antes, suas narrativas trazem tentativas de explicação das origens, como se as questões fundamentais sobre elas, fossem impostas àqueles que a veiculam. Para Lacan, tais questões marcam a posição cindida daquele, ou daqueles, que a enunciam.

A metonímia a que se refere o psicanalista nesta passagem, por outro lado, é a metonímia própria dos processos de significações no inconsciente, cujos pontos de estofo, de parada do deslocamento significante, articulados simbolicamente, respondem por uma relação de gozo. Se a metonímia, em um primeiro momento da obra lacaniana, enfatizava o deslocamento próprio do desejo em sua sempre falha tentativa de realização em um determinado objeto, neste desenvolvimento tardio de Lacan, a ênfase recai sobre o papel do gozo produzido por tais significações. Ora, mas isso implica uma maior inflexão sobre a dinâmica do real enquanto impossível. 
Como vimos, Lacan, ao reler o impossível expresso pelo mito, leva sua análise sobre o papel aí desempenhado por essa ordem contínua, cromática, em sua graduação, que é o gozo. Na releitura da linguagem sob essa chave, Lacan forja um novo termo para retomar o valor da linguística para a psicanálise. Em seus termos:

O inconsciente, isso fala. o que o faz depender da linguagem, da qual pouco sabemos, apesar do que designo como linguistería, para nela agrupar o que pretende - essa é a novidade - intervir nos homens em nome da linguística. A linguística é a ciência que se ocupa de lalíngua, que escrevo numa palavra só, para com isso especificar seu objeto, como se faz em qualquer outra ciência. (LACAN, 1973, p.510).

Ao separar o campo de incidência da mirada psicanalítica sobre a aquela própria da linguística, Lacan assume que seu projeto, antes de atentar para os determinantes formais de uma linguagem, responde pela inscrição do sujeito nesta. A linguisteria, palavra inventada para lidar com esse reposicionamento, trata do significante não apenas como unidade discreta de um sistema global de linguagem, mas como "situado no nível da substância gozante, como a causa do gozo" (LACAN, S.XX, p.36). Vejamos as consequências desse fato para a leitura do modelo introduzido por Lévi-Strauss.

Esse afastamento em relação à linguística, operado por Lacan, não implica necessariamente uma desvalorização do modelo apresentado pela fórmula canónica do mito. Como dissemos, o grande valor desse modelo à teoria lacaniana, é permitir a formalização de um sistema de linguagem habitado por um sujeito, mesmo que este se equacione em suas hiâncias. O impossível introduzido por essa fórmula, em especial expresso pela dupla torção final, é justamente o ponto de articulação de Lacan com a teoria linguística. Entretanto, resta-nos uma questão: qual a consequência para a consideração deste modelo, dos desenvolvimentos lacanianos sobre o papel do real na linguagem? Poderíamos reler a fórmula a partir da noção de lalíngua? Tomemos este termo.

A noção de lalíngua desponta no pensamento lacaniano justamente para responder a questões acerca do papel do gozo sobre a linguagem, particularmente no ponto em que a relação do sujeito com a linguagem excede a articulação simbólica. 
Lalíngua pode ser definida como o que da língua "materna" o "sujeito recebe como aluvião, chuva, tormenta de significantes próprios àquela língua idiomática e que se depositam para ele como material sonoro, ambíguo, equívoco, repleto de malentendidos, com diversos sentidos e, ao mesmo tempo, sem sentido" (QUINET, 2009a, p.71). Lalíngua é feita de gozo e sustentada na "relação que o ser falante estabelece com o seu corpo" (LACAN, S.XIX, p.27). Nas palavras de Lacan:

Há um esforço de pensamento a ser feito para que se funde a linguística a partir disso. De seu objeto, o significante. Não há um só linguista que não se apegue a destacá-lo como tal, e sobretudo a destacá-lo do sentido. Falei em vertente do signo para assinalar sua associação com o significante. Mas o significante difere dele pelo fato de sua bateria já se dar em lalíngua. Falar de código não convém, justamente por pressupor um sentido. A bateria significante de lalíngua fornece apenas a cifra do sentido. Cada palavra assume nela, conforme o contexto uma gama enorme e disparatada de sentidos, sentidos cuja heteróclise se atesta com frequência no dicionário. (LACAN, 1973, p.514-5).

Ora, a partir dessa definição uma bateria significante se articularia a partir da extimidade impressa em lalíngua, deste registro do sem sentido que decola do sentido e inscreva uma relação de gozo do sujeito no campo da linguagem. Retomo a questão: seria essa noção válida para lermos o modelo de formalização das estruturas míticas

proposto por Lévi-Strauss? Assim, como vimos no caso do mito de Édipo, tomemos o caso freudiano do Homem dos Ratos, tal qual relido por Lacan, para verificar o valor do modelo lévi-straussiano sobre a explicitação dos determinantes da mítica individual própria da neurose.

\section{O caso do Homem dos Ratos relido a partir da estrutura quaternária dos mitos}

Em O mito individual do neurótico (1953), como já referido, Lacan “aplica” a grade estrutural do modelo de formalização mítica, recém adquirido pelo contato com Lévi-Strauss, ao caso descrito por Freud em Notas sobre um caso de neurose obsessiva (1909), e que ficou amplamente conhecido como o caso do Homem dos Ratos. Ao 
recorrer ao tema do mito, Lacan buscava demonstrar a função das estruturas míticas no determinismo dos sintomas e da vivência em geral do neurótico. Com isso, além de integrar à sua obra o postulado lévi-straussiano de que a neurose se estrutura como um mito individual, o psicanalista francês dava o tom do que seria sua assimilação do método estrutural, de modo a demonstrar seu "valor para explicar a história do Homem dos Ratos" (LACAN, S.VIII, p.370). Tomemos o caso freudiano.

Em outubro de 1907, Freud recebe em seu consultório um jovem tenente da força militar do império Austro-húngaro e doutor em jurisprudência, Ernst Lanzer. Este recorrera a Freud, tomado de intensa angústia produzida pelo crescente volume de ideias obsessivas. Ao longo de seu tratamento Lanzer relata diversos momentos de críticos, em que estivera praticamente tomado por seus pensamentos obsedantes. Neste percurso, que durou cerca de um ano, Freud recolhera fragmentos de história para reconstruir o que seriam os conflitos centrais de seu drama. Ao nomear seu paciente como o Homem dos Ratos, Freud dava claras mostras do valor por ele dado à fantasia que desencadeou o último momento de sua crise, aquele que levaria o sujeito até a clínica do psicanalista.

Dentre os vários momentos relatados de sua gesta, dois momentos se configuram como exemplares de seus conflitos: primeiramente, temos o momento inaugural de aparição de suas ideias obsessivas. Neste encontramos Lanzer estudando para um concurso público (FREUD, 1909, p.259), cujo sucesso condicionava a possibilidade financeira de se casar com a mulher a que estava destinado, uma prima distante altamente recomendada pela família, Gisela. A questão com o casamento, envolvia ainda dois outros fatores: (a) Gisela, que durante anos rejeitara suas investidas, a despeito do prestígio familiar, não era dotada de posses, o que faria com que seu casamento ficasse condicionado ao emprego público de Lanzer, ou, como bem expressa uma de suas ideias obsessivas, à morte de seu pai, cuja herança permitiria o matrimônio. (b) outro fator importante, é o dado de que Lanzer, em uma das paradas militares envolvera-se com uma garçonete, com quem teve suas primeiras experiências sexuais, e que fora dotada da mais alta estima.

O outro momento de desencadeamento crítico de suas ideias obsessivas, fora o último antes de sua chegada a Freud. Durante o período de descanso de uma das manobras militares, Lanzer em conversa com seus colegas, escuta do Capitão M, 
manifestamente afeito a crueldades, o relato de um terrível suplicio oriental, que envolvia o uso de ratos. Nas palavras de Freud:

"Pois bem, durante a parada passamos a conversar, e o capitão contou-me que havia lido sobre um castigo particularmente horrível aplicado no Leste...”. Aqui o paciente interrompeu-se. [...] Continuei, dizendo que faria tudo que pudesse para, não obstante, adivinhar o pleno significado de quaisquer pistas que me fornecesse. Será que ele estava pensando em cerca de estacas? - "Não, isso não;... o criminoso foi amarrado..." - expressou-se ele tão indistintamente, que não pude adivinhar logo em qual situação - “...um vaso foi virado sobre suas nádegas... alguns ratos foram colocados dentro dele... e eles..." - de novo se levantou e mostrava todo sinal de horror e resistência - "cavaram caminho no..." - Em seu ânus, ajudei-o a completar. Em todos os momentos importantes, enquanto me contava sua história, sua face assumiu uma expressão muito estranha e variada. Eu só podia interpretá-la como uma face de horror ao prazer todo seu do qual ele mesmo não estava ciente. (FREUD, 1909, p.171 - grifo do autor).

Ao ouvir a cena da tortura dos ratos, Lanzer, muito impressionado, foi tomado pela ideia de que "isso estava acontecendo com uma pessoa que me era muito cara", posteriormente nomeadas: sua bem-amada Gisela e seu pai. O caráter absurdo desse pensamento estava no fato de que dificilmente um castigo como esse seria aplicado em uma dama e que, mais absurdo ainda, seria aplicado ao seu pai que falecera há anos.

Este momento de crise se desdobra em um segundo desenvolvimento: na mesma noite em que ouvira o relato, o Capitão M. entrega a Lanzer um par de óculos (pince-nez) que este havia encomendado, e diz que deveria reembolsar as despesas ao Tenente A, responsável pelo serviço de correio. Uma injunção viera naquele momento: ele deveria reembolsar o Tenente A, ou o suplicio dos ratos ocorreria com a dama ou seu pai. Entretanto, o Capitão M, não estava ciente de que naquele momento o Tenente B que assumira as funções do correio. Portanto, se quisesse quitar sua dívida, Lanzer deveria pagar o Tenente B. Mas isso lhe impediria de responder ao imperativo de pagar 
o Tenente A. Aqui outro complicador entra: como Freud descobriria mais tarde, logo no começo das dificuldades em quitar o valor de sua encomenda, Lanzer já sabia que quem havia, de fato, pago seus óculos tinha sido uma senhora que trabalhava nos correios, portanto, nem o Tenente A, como dito pelo Capitão M., nem o Tenente B., responsável pelos correios. Então ele monta um roteiro de como tratar a situação:

Ele urdira um meio muito curioso de sair da sua dificuldade; ou seja, ele iria à agência postal com ambos os homens, A. e B., A. daria lá à jovem dama, as 3.80 coroas, a jovem dama as daria a B., e então ele mesmo devolveria em pagamento as 3.80 coroas a A., segundo as palavras de seu juramento. (FREUD, 1909, p.173).

Como podemos ver, esse roteiro imaginário é impossível de ser seguido. Pois, no fim das contas, a senhora dos correios que arcaria com sua despesa. Este é o grande conflito em que está inserido, quando busca Freud, aconselhado por um amigo próximo, em um estado máximo de angústia. Acerca deste ponto Lacan nos diz:

Esse roteiro fantasístico apresenta-se como um pequeno drama, uma gesta, que é precisamente a manifestação do que chamo o mito individual do neurótico. [...] O que dará seu caráter mítico a esse pequeno roteiro fantasístico? Não é simplesmente o fato de encenar uma cerimônia que reproduz de forma mais ou menos exata a relação inaugural que aí se encontra como que escondida - ele a modifica no sentido de uma tendência. [...] Tudo se passa como se os impasses próprios da situação original se deslocassem para um outro ponto da rede mítica, como se o que não é resolvido num lugar se reproduzisse sempre noutro. (LACAN, 1953, p.26-7).

Portanto, o estatuto mítico da construção de Lanzer estaria no fato de ela se articular com toda a constelação própria de problemas das gerações anteriores, no caso, de seus pais. O valor exemplar deste relato encontra-se justamente, nos termos de Lacan, na clareza de demonstrar "a coerência significante que existe entre a primeira constelação e a que se segue" (LACAN, S.VIII, p.332). Ao extrair uma lógica mítica do conjunto de histórias fragmentárias relatadas por Lanzer, Lacan demonstra o valor do 
modelo lévi-straussiano na articulação das tendências próprias da transformação entre as duas gerações. Ainda sobre este tema:

A constelação original que presidiu ao nascimento do sujeito, ao seu destino e quase diria à sua pré-história, a saber, as relações familiares fundamentais que estruturam a união de seus pais, mostra ter uma relação muito precisa, e talvez definível por uma fórmula de transformação, com o que aparece como o mais contingente, o mais fantasístico, o mais paradoxalmente mórbido de seu caso, a saber, o último estado de desenvolvimento de sua grande apreensão obsedante, roteiro imaginário a que chega como se fosse à solução da angústia ligada ao desencadeamento da crise. (LACAN, 1953a, p.19).

Vemos aqui, portanto, a clara alusão de Lacan à fórmula de transformação mítica. Ora, pela análise do psicanalista francês, o mais contingente de sua vivência mostra-se articulada sob um certo viés com uma série de traços da relação dos pais, tal qual apreendida pelo sujeito, e que são de importância decisiva para a compreensão de sua gesta. Tomemos os termos da constelação original.

O tema da dívida, encontrada em Lanzer, está presente na história de seu pai. Heinrich Lanzer também servira ao exército, mas, no começo de sua carreira, na condição de um oficial não comissionado, portanto um suboficial, que em seu trato com os demais, sempre fora "muito suboficial". A este traço se ligava um caráter extremamente generoso, cordial, de bondosa tolerância que lhe valia a simpatia e afeto de seus próximos (Cf. FREUD, 1909, p.185). No período que acercou seu casamento o pai esteve diante de um questionamento sobre casar-se com uma mulher rica, dotada de prestígio e status social, ou casar-se com uma bela e pobre costureira a quem então reservava seus afetos, e tivera uma rápida relação. O pai escolhera a mulher rica, que viria a se tornar mãe de Lanzer, com a qual teria um casamento pleno de afeição. Dentre as inúmeras brincadeiras entre seus pais, havia uma em que a mãe lembrava o fato, enquanto seu pai protestava, dizendo que havia sido algo passageiro, e já ultrapassado. Mesmo em tom espirituoso, tal relato marcara, como pudemos ver, o drama futuro de Lanzer. 
Porém, há outro elemento importante para a apreensão da mítica familiar do Homem dos Ratos. Durante uma das manobras militares, Heinrich, conhecido por seu vício em jogo, perdera grande parte dos fundos do regimento, que estava a sua disponibilidade dado o posto por ele ocupado. Havia colocado em jogo não apenas sua honra como todo o futuro de sua carreira militar. Sua salvação fora a intervenção de um amigo que lhe emprestara a quantia necessária para resolver sua dívida. Entretanto, fato importante é que devido aos destinos de cada um, Heinrich nunca pode quitar sua dívida com este amigo. Nos termos de Lacan:

Para entender bem, é preciso ver que na situação original, tal como a descrevi, há uma dupla dívida. Por um lado, a frustração ou até uma espécie de castração [na substituição da mulher pobre pela mulher rica]. Por outro lado, a dívida social nunca resolvida, implicada na relação com o personagem, em segundo plano, do amigo. Trata-se de algo bem diferente da relação triangular considerada típica na origem do desenvolvimento neurotizante. A situação apresenta uma espécie de ambiguidade, de diplopia - o elemento da dívida está situado em dois planos ao mesmo tempo, e é precisamente na impossibilidade de fazer esses dois planos se encontrarem que se desenrola todo o drama do neurótico (LACAN, 1953a, p.27).

Encontramos, portanto, uma regularidade entre as particularidades das duas gerações que formam a rede de determinações do conjunto sintomático do Homem dos Ratos. O neurótico, como nos diz Lacan, encontra-se em sua vivência numa situação de quatour persistentemente renovada, na qual acha-se impossibilitado de unificar os planos dois planos: o primeiro seria o de sua relação com o trabalho e os frutos deste, a que Lacan denomina sua "função viril e no trabalho" (Ibidem, p.29); o segundo seria o plano da possibilidade de gozar de forma serena e unívoca do objeto sexual. Sejamos mais específicos. O tipo de ambigüidade conservado na vivência do neurótico é marcado, por um lado, pelo desdobramento de seu objeto de amor quando de sua tentativa de unificar a outra ponta da cadeia, a "função virill", que faz com que seja muito comum que o relacionamento atual deste seja anulado em prol de uma personagem distante e ideal, com a qual se identifica mortalmente. Por outro, lado quando este se esforça para unificar o plano de sua "sensibilidade", a outra ponta é que 
se desdobra e ele se identifica a um personagem a quem delega o fardo de viver em seu lugar.

Ora, a partir destes termos, podemos, a título de hipótese, buscar apreender a regularidade das transformações impressas de uma geração a outra, de modo a explicitar o valor do modelo da fórmula canônica do mito para a leitura lacaniana do caso de Freud, assim como seu amplo valor a compreensão das particularidades da produção de seus mitos individuais. Por tais fatores encontramos a seguinte notação:

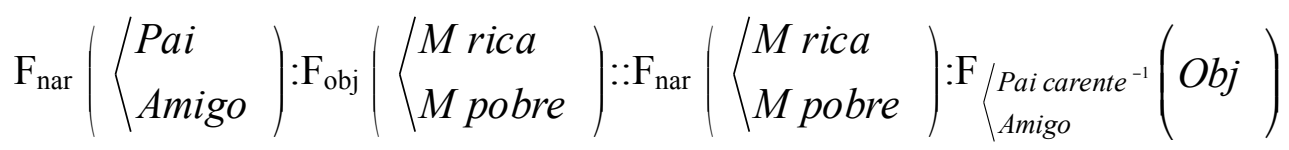

Observemos seus termos: os dois primeiros conjuntos da esquerda tratam da geração dos pais de Lanzer. Encontramos aí um pai humilhado por conta de uma dupla dívida - esta real a um membro perdido, o amigo, e simbólica a um membro real, sua esposa. Entretanto, a primeira dívida, que responde pela função de seu reconhecimento social, nomeada por Lacan como narcísica, inscreve o pai como carente diante do amigo bem-feitor que lhe quitou a dívida. A segunda, por sua vez, que trata da relação de objeto, explicita a divisão entre a Mulher rica e Mulher pobre, com sua escolha tendendo para aquela a qual ele deve sua atual condição financeira e de prestígio burguês.

Ao passarmos para a segunda geração, encontramos, no terceiro termo, uma função narcísica estranhamente ligada ao desdobrado elemento Mulher rica/Mulher Pobre. No caso deste terceiro termo, poderíamos relacioná-lo, e.g., ao roteiro imaginário construído a partir de dívida real com a senhora dos correios, que na situação coloca-se como rica e, por conta da atualização de todo esquema, será prontamente aproximada com a mulher a que está destinado a casar. A partir do sistema é imposto o desdobramento, a contraposição a uma mulher pobre fantasisticamente idealizada que o levará a uma "identificação de ordem mortal” (LACAN, 1953a, p.30), decorrente de um “amor-paixão”. O quarto termo, por sua vez, merece uma atenção especial.

A intrincada dupla torção aí presente, que confere o valor da transformação mítica da fórmula, permite alguns esclarecimentos sobre a estrutura da neurose obsessiva. Nele encontramos um conjunto que, por sua abertura à rede de esquemas míticos, poderia ser entendido como a função genérica da relação do sujeito com os 
objetos $[(o b j)]$. Esta relação, no entanto, é matriciada pelo negativo da imagem do pai carente, faltante. Eis o passo dedutivo da fórmula que permite à psicanálise vislumbrar expressamente nas formações neuróticas uma das figuras necessárias para a assunção do sujeito enquanto Consciência de si e apagadas pela história, a saber, "a figura do Mestre" (LACAN, 1953a, p.14). A um pai real brando, excessivamente faltante, interpõe-se, como efeito de estrutura, um pai imaginário, todo, aterrorizante em suas relações com o sujeito. A possibilidade, portanto, de aproximação entre mítica individual da neurose obsessiva e a dialética do Senhor e do Escravo, teria sido, nos dizeres de Simanke (2002), um dos principais motivos para Lacan ter escolhido o caso do Homem dos Ratos para inaugurar sua referência ao ideário estrutural. Neste contexto, consideremos as particularidades deste quarto elemento.

Como vimos, um das principais características do mito é sua faceta produtora e reprodutora de diferentes versões de suas narrativas. No contexto de uma análise, como vimos desde Freud e Lévi-Strauss, o mito produzido aí inscreve-se na totalidade sintomática do sujeito. No caso do Homem dos Ratos, Freud foi bem sensível à maneira como seu paciente posicionou-se na dinâmica transferencial. Em um primeiro momento, Freud aparece como um substituto, nas relações afetivas de Lanzer, de "um amigo que desempenhava um papel de guia, conselheiro, protetor, tutor tranquilizador, que depois de ouvir a confidencia de suas obsessões e angustias lhe dizia regularmente: 'Você nunca fez o mal que acredita, você não é culpado"” (Ibidem, p.28). Posteriormente, já nas primeiras sessões acontece uma reviravolta sobre este lugar e Freud então é sujeito às fantasias agressivas da parte de Lanzer. Surge então uma ambiguidade na relação com Freud, de um lado, o psicanalista é visto como um personagem protetor dotado de todos os bens da Terra, e que buscaria lhe ceder em matrimônio a própria filha, de outro, Freud é colocado como um sujeito maléfico, terrível que buscaria the recriminar. Lacan associa esse segundo tempo da transferência como correlato não apenas da inversão da relação amigável, benevolente com o pai, mas que também responderia pela característica própria da relação narcísica estabelecida com a mulher rica que em sua geração, substituíra o lugar do amigo.

Sobre o lugar das inversões e produções próprias da transferência em uma análise, Lacan nos diz: "mito e fantasia se juntam aqui e a experiência passional, ligada à vivencia atual da relação com o analista, serve de trampolim, por intermédio das identificações que comporta, para a resolução de alguns problemas" (LACAN, 1953a, 
p.29). Ora, vimos como o pensamento lévi-straussiano denominava tal dinâmica como a experiência, ou antes, a vivência intensiva de um mito em um conjunto ritual. Entretanto, ao trazer a temática lacaniana da articulação entre mito e fantasia, podemos dar ainda um outro passo na análise deste quarto elemento.

Até o momento não analisamos um dado primordial da mítica do Homem dos Ratos. No caso da lenda de Édipo, seu nome Oidipous, aparece como dado central para compreender, em nossa hipótese, o conjunto de seu mito. Por sua materialidade significante, Oidipous ressoa como a resposta impossível à questão fundadora do mito. Algo próximo a isso é encontrado no caso que ora analisamos. É justamente na ideia do rato que Freud identifica um princípio de determinação de seus conflitos e sintomas.

Logo no início do tratamento, ao definir os honorários a serem pagos, Lanzer diz a si próprio: "tantos florins, tantos ratos" (FREUD, 1909, p.. Ele aí já demonstra uma primeira significação do elemento ratos, a saber, sua equivalência a dinheiro. Entretanto, há diversas significações intrincadas em sua rede mítica, como nos diz Freud:

Aquilo que a punição com ratos nele incitou, mais do que qualquer outra coisa, foi o seu erotismo anal, que desempenhara importante papel em sua infância e se mantivera ativo, por muitos anos, por via de uma constante irritação sentida por vermes. Desse modo, os ratos passaram a adquirir o significado de 'dinheiro'. O paciente deu uma indicação dessa conexão reagindo à palavra 'Ratten' ['ratos'] com a associação 'Raten' ['prestações']. Em seus delírios obsessivos ele inventou uma espécie de dinheiro regular como moeda-rato. [...] Paulatinamente traduziu para a sua língua o complexo inteiro de juros monetários centrados em torno do legado que lhe daria o pai; isso quer dizer que todas as suas ideias correlacionadas com aquele assunto se reportavam, por intermédio da ponte verbal 'Raten-Ratten', à sua vida obsessiva e caíam sob o domínio de seu inconsciente. (FREUD, 1909, p.215)

Vemos, portanto, o elemento raten, presente desde dívida na constelação originária, como um dos determinantes para a forte impressão causada pelo relato do 
suplício dos ratos. A "ponte verbal” a que alude Freud compõe-se ainda de uma série de outros elementos: o termo significante raten, encontra-se além das prestações, dívidas (Raten) e dos ratos (Ratten), no termo que designa o casamento (Heiraten), e na ligação do pai com o jogo, posto que este era considerado um rato de jogo (Spielratte). Ora, encontramos agrupados em torno da materialidade sonora deste significante a totalidade dos temas centrais de sua mítica individual. Poderíamos considera-lo como análogo ao caso de Oidipous?

Uma das definições de mito realizadas por Lacan, como vimos neste capítulo, é a de uma estrutura discursiva que, através de um equacionamento significante, responderia "ao insolúvel significando a insolubilidade, fornecendo, assim, (esta seria a função do mito) o significante do impossível" (LACAN, 1956, p.91). Ao analisar as incidências da temática do impossível articulada à dimensão do significante, vimos como a estrutura do mito, expressa matematicamente pela fórmula canônica do mito, responde a diferentes campos conceituais na obra lacaniana. No cerne das distintas modalidades de inscrição do significante na lógica mítica, a dupla torção final sintetizaria, por seus postulados, o papel de um significante especial que sustentaria a cadeia significante, no caso, da série mítica. Não por acaso, portanto, o sistema quaternário proposto por Lévi-Strauss, poderia ser lido como um meta-modelo de formalização para o projeto lacaniano, no conjunto de seus diferentes contextos. Dessa análise, vimos o quarto termo da fórmula como representando a característica da linguagem de se fundar como conjunto a partir de um elemento êxtimo. Seja como Nome-do-pai, falo, Significante da falta no Outro ou ainda como a incidência da lógica do objeto sobre a linguagem, como em lalangue, este termo é condição sine qua non para a formação de uma série mítica, seja no caso do mito individual do neurótico, ao qual nos deteremos à frente, seja no caso de um mito coletivo, como é o caso de Édipo.

Tanto Ratten, como Oidipous servem de nomes aos heróis de seus respectivos mitos, mas nomes que sustentam a singularidade da determinação mítica de cada um. Seus nomes, no que resguardam de não-sentido - portanto, abertos à multiplicidade de significações - são responsáveis por engendrar toda uma cadeia de significantes essenciais para suas respectivas gestas. Se no mito de Édipo, vimos seu Oidipous operar, pelas vias da materialidade do significante, a aproximação entre uma pergunta sem resposta, um enigma, a uma resposta sem pergunta, incesto, no caso do Homem dos Ratos, como analisado por Lacan, temos um passo adicional. 
Uma das funções do mito seria inscrever na lógica da linguagem as referências para a emergência de um sujeito, sujeito marcado por uma divisão fundante. Por esta via, o mito funcionaria como um modo de articular, sob a forma de uma questão, a marca de sua falta constitutiva. Essa forma de articular a questão, contém em si a busca de sua resposta, a resposta pelo desejo do Outro, resposta impossível pela qual cada termo que analisamos traria uma dimensão diferente. Mas não devemos considerar fortuita a menção, ainda que posicionada nos primeiros escritos de Lacan, de que mito e fantasia se uniriam no contexto de um tratamento.

Enquanto um modo de inscrever a bateria de significantes que determinará as particularidades da experiência vivida por um sujeito, o mito parece dar a determinação simbólica do que virá a ser a fantasia. A partir do grafo do desejo, como vimos, temos formalizado no ensino de Lacan a relação entre a falta de resposta acerca do desejo do Outro, lá expressa por um “Che Vuoi?”, que abre a dimensão do inconsciente para a formação de uma fantasia que busque, em um registro distinto, responder à tal relação e servir de tela configuradora da rede de sintomas a partir daí formados. Através do mito do Homem dos Ratos, vemos como o significante Ratten, extraído do não-sentido sonoro que se eleva dos termos conflitantes da geração de seus pais, é central para a captura que o relato do suplício dos ratos opera sobre Lanzer. Esta proposta de leitura, não exclui a diferença entre mito e fantasia no que concerne aos seus registros fundamentais: a fantasia possui uma estrutura de cena, enquanto o mito a de roteiro. Aprofundando-nos na metáfora cinematográfica, poderíamos dizer que se o mito dá as coordenadas simbólicas para a construção da cena, esta última depende ainda de fatores presentes em dois outros registros: os fatores de imagem - imaginários - e de corte de câmera e perspectiva constitutivos - reais.

Podemos ver, portanto, o quarto elemento da fórmula de transformação mítica, como operando uma passagem entre o registro simbólico, estrutural, e o real próprio de uma perspectiva histórica, na qual a noção de contingencia traz a marca da impossibilidade de apreensão a priori.

Vimos neste capítulo como a apropriação da formalização do fenômeno mítico executado por Lévi-Strauss foi essencial para o projeto lacaniano de retomada da obra freudiana e de reinserção na teorização da experiência analítica, da função e eficácia 
simbólica. Entretanto, uma hipótese aqui lançada foi a de que tal momento constitutivo de tal importação conceitual teve efeitos sobre a totalidade da reflexão sobre a dinâmica do simbólico, assim como sobre os modelos de formalização que merecem uma maior consideração para bem posicionarmos tanto as principais coordenadas do diálogo entre Lacan e Lévi-Strauss, quanto os recursos teóricos da própria teoria lacaniana.

No interior deste percurso, encontramos inúmeros pontos de convergência entre a apropriação lacaniana da noção de mito e aquela analisada no contexto da obra freudiana. O mito, tanto em uma como na outra, fornece as bases para a compreensão dos determinantes simbólicos que estruturam uma neurose, com seu valor estruturante da experiência cotidiana e de formação sintomática específica. Portanto, o papel de explicitação dos condicionantes de uma semiologia dos fenômenos clínicos, em especial através da reencenação própria da dinâmica da transferência, tem um valor central para o postulado de uma sistematicidade que almeja um valor universalizante. Das três maiores distinções entre Freud e Lacan nesta temática, encontramos: (1) a relativização expressa por Lacan sobre o papel universal e unificante de édipo em discursos míticos provindos de diferentes culturas, histórica e temporalmente distantes; (2) a distinção entre os campos de atuação do mito de édipo, Totem e Tabu, como respondendo a questões distintas; (3) a particularidade da importação lacaniana da teorização sobre o mito vir acompanhada de um modelo matemático de formalização que lhe permitiu derivar tanto um modelo próprio de articulação do sujeito com a linguagem, como um meta-modelo para as demais empreendimentos de formalização realizados ao longo de sua obra.

No que concerne à relação com Lévi-Strauss, vimos como o modelo da formula canônica permitiu a Lacan, antes de conceber um instrumento de análise discursiva, levou-o a um recorte da preeminência da lógica significante na qual um sujeito se inscreve. No interior de um enigma fundamental, equacionado pelo mito, a fórmula mítica permitiria apreender como as hiâncias fundamentais expressas em suas contradições insolúveis - condição de emergência do sujeito para Lacan - são sustentadas pela particularidade de um quarto termo especial, este que abarca o princípio da diferença e da articulação em cadeia dos significantes que guiam um destino. Deste ponto, buscamos mapear as formas deste significante do impossível que se articulam na obra lacaniana, assim como a inflexão do entendimento que a sustentação da cadeia simbólica do mito sofre a partir da teorização sobre a ordem do 
real. No interior deste percurso, partimos para a análise de como a leitura da fórmula canônica, conjugada a partir da obra lacaniana, poderia auxiliar a compreender e formalizar os determinantes particulares das transformações próprias ao mito individual do neurótico. 


\section{CONCLUSÃO}

À guisa de conclusão deste trabalho, podemos retomar os principais movimentos da empreitada aqui realizada, de modo a recompor os eixos fundamentais que nortearam nosso recorte.

Partindo da obra de Freud, vimos que a inscrição da temática do mito em seu pensamento é coetânea da própria revisão do estatuto da palavra na experiência clínica e, consequentemente, da emergência da psicanálise como uma prática sui generis. $\mathrm{O}$ mito de Édipo, neste contexto, aparece como uma narrativa cujo valor universal se sustentaria no reconhecimento e identificação que cada pessoa efetuaria com os conflitos e dramas ali expressos (FREUD, 1897). A possibilidade de encontrar uma narrativa que transcenda, em sua eficácia simbólica, os limites da história e da geografia, marcou para Freud a necessidade de retomar a dinâmica da constituição subjetiva a partir da tensão entre fatores históricos, particulares de cada indivíduo, e fatores universais, que respondiam à humanidade em geral. Por esta via, observamos como a noção de mitos endopsíquicos (FREUD, 1901), marcaram para o psicanalista a possibilidade de reinscrever os conflitos impressos em tais narrativas, no centro fundante de uma psicologia do inconsciente. Portanto, a temática do mito apresenta-se, nos primórdios da teoria psicanalítica, como um meio privilegiado para a construção de uma metapsicologia.

Acompanhamos como Freud insere tal temática nos fundamentos da leitura da experiência clínica. Ao reconhecer seu papel estruturante para a configuração dos conflitos centrais de cada sujeito, o psicanalista ressitua o valor de tais fenômenos para a concepção da dinâmica transferencial. Por esta via, a análise mitológica seria uma das chaves para a compreensão das posições simbólicas assumidas e produzidas ao longo de uma análise. Mais do que simplesmente reproduzir, no interior de uma relação analítica, uma série de papeis e conflitos seriam produzidos, tornando possível, assim, a influência transformativa de um trabalho de análise sobre a economia libidinal do paciente (FREUD, 1914).

Entretanto, encontramos ainda um terceiro movimento realizado por Freud na temática do mito. Se ao psicanalista foi possível, por um lado, reconhecer na mitologia os conflitos fundamentais do homem e, por outro, reconhecer seu valor para a leitura 
das principais posições assumidas no interior de uma relação transferencial, Totem $e$ Tabu (1913) marca uma via distinta. Nesta obra, Freud revoluciona os termos nos quais se dava sua interlocução com as ciências sociais: ao valer-se de um referencial antropológico extenso, Freud faz dos dados etnológicos um meio para inserir sua contribuição a partir das descobertas psicanalíticas de então.

Com o intuito de inscrever a pretensa universalidade do Édipo na origem histórica da cultura e da sociedade, Freud vale-se de uma hipótese por ele denominada de um mito histórico, a saber, a hipótese da Horda Primeva. Este se caracterizaria como um evento arcaico, situado nos limites da história, que teria conformado uma estrutura presente e permanente. Por esta via, o psicanalista eleva o mito ao estatuto de uma formulação científica. O valor metodológico reconhecido à lógica do mito por Freud, torna possível a construção de uma narrativa pretensamente mítica, ou ao menos de seus elementos fundantes, para a explicitação de fatores determinantes dos fatos sociais e dos dramas individuais que se fazem presentes na experiência clínica. Em outros termos, com Totem e Tabu Freud inverte o vetor das relações com as ciências sociais e permitese reconhecer em uma narrativa construída um estatuto de verdade, por sua eficácia significante no plano coletivo e individual.

A partir deste primeiro momento, vimos como nos anos que se seguiram à publicação do clássico freudiano, quase a totalidade da interlocução com as ciências sociais, em especial com a antropologia, foram pautadas por modulações e discussões das teses aí expressas. Dos quatro expoentes da disciplina antropológica que trouxemos para situar globalmente o lugar da psicanálise e do mito na interlocução aí realizada, observamos como a ausência de uma concepção sistemática do fenômeno mítico, enquanto meio simbólico estruturado de forma análoga à totalidade dos fatos sociais, fez com que os postulados de Totem e Tabu fossem amplamente recusados. A resistência à ambição da hipótese freudiana, portanto, não teria sido provocada apenas pelas críticas prévias às suas fontes etnológicas, ou por sua pretensão de reconstruir uma "história ahistórica": os termos deste diálogo passam prioritariamente, como vimos, pelo lugar inerente do mito em seus sistemas conceituais. Neste cenário, a obra de LéviStrauss, além de sintetizar as principais linhas de força das vertentes etnológicas inauguradas por Malinowski, Rivers, Boas e Mauss, fora a primeira a reconhecer o valor mítico do escrito freudiano, assim como o papel seminal do plano epistemológico na qual se situa a teoria psicanalítica para um projeto antropológico estrutural. 
Acompanhamos na obra de Lévi-Strauss como as modalidades de uso do mito na teoria psicanalítica sofrem uma transformação global. Se com Freud, o mito de Totem e Tabu coloca-se como um evento histórico, em Lévi-Strauss sua potência mítica estaria na justa medida em que explicita discursivamente a relação sincrônica e permanente da dinâmica entre as ordens da natureza e da cultura (LÉVI-STRAUSS, 1949a). A dimensão estrutural do mito, enquanto meio privilegiado de acesso às regras lógicas de linguagem determinantes dos fenômenos sociais, será salientada como parte central de todo seu programa antropológico. Neste ponto, portanto, considerando o mito por seu valor metodológico para a formalização de uma disciplina, vemos a proximidade entre Freud e Lévi-Strauss, que chegará mesmo a definir o percurso das Mitológicas (1964-1971) como a produção de um “mito da mitologia” (LÉVISTRAUSS, 1964, p.35).

A inscrição do mito na lógica de produção da dinâmica transferencial se, por um lado, será brevemente abordada por Lévi-Strauss, por outro, exerce o papel fundamental, no período inicial de sua obra, de argumentação em prol da eficácia do registro simbólico sobre o conjunto das experiências e vivências dos homens (LÉVISTRAUSS, 1949b, 1949c). Ainda balizando a inserção da temática do mito na obra do antropólogo com a posição deste na produção freudiana, podemos salientar que o viés estrutural e sincrônico de suas análises não deixam de ressituar a história e a perspectiva diacrônica como centrais para a determinação de uma estrutura. Antes de assimilar o conceito de estrutura a uma forma abstrata de condicionamento total da realização dos fenômenos sociais, Lévi-Strauss o conceberá prioritariamente pela regularidade das transformações, variações de um dado conjunto de fatos.

No interior do contexto das análises mitológicas, vimos como o antropólogo dá um importante passo para a sistematização dos fatores condicionantes deste fenômeno, ou melhor, para sua formalização: acompanhamos como Lévi-Strauss (1955) constrói um modelo matemático para conceber o conjunto de transformações das narrativas míticas, a fórmula canônica do mito. Vislumbramos, então, as particularidades de tal modelo, os desvios interpretativos por conta de seus sucessores, assim como as derivações e consequências lógicas extraídas pelo próprio antropólogo para se tratar a relação da mitologia com o conjunto de produções culturais. 
O potencial desta fórmula de articular a dimensão de um impossível expresso pela via significante no mito, tornou-a central para a apropriação lacaniana de seus termos. Ela marcou, como consideramos em detalhes, o princípio da assimilação estrutural enquanto forma na obra do psicanalista francês (LACAN, 1953a). Portanto, desde seu princípio, o endereçamento a uma lógica estrutural nunca foi dissociada, no pensamento lacaniano, de uma vertente dialética, histórica na qual a referência a um sujeito, efeito de linguagem, pode se articular.

Entretanto, a inscrição do modelo da fórmula canônica marca ainda uma revisão global do seu entendimento da neurose e da experiência clínica. A reaproximação da obra freudiana, tal qual expresso em seu projeto maior de Retorno a Freud (1953b), se não é fortuita, já se regula, por sua vez, a partir de um estatuto conceitual distinto. Munido da linguagem formal propiciada pela linguística estrutural e, essencialmente, pela antropologia lévi-straussiana, Lacan encontrará meios de sistematizar a experiência psicanalítica a partir de construtos derivados da lógica matemática. Mas vimos as particularidades desta derivação em três esferas distintas.

Em primeiro lugar, a noção de mitema presente no modelo lévi-straussiano estabelece um princípio metodológico central para a determinação das posições simbólicas, significantes no interior de uma análise. Em outros termos, a temporalidade impressa na explicitação dos termos que compõem a fórmula canônica, são exatamente aqueles que Lacan se vale para extrair um significante de uma narrativa. Como vimos, um mitema apresenta duas características básicas: (a) são pacotes de relações, relações que exprimem um valor funcional a partir do conjunto de outras relações; (b) são difusos, posições significantes não imediatamente acessíveis, à diferença da noção linguística do termo e daquela utilizada por Lévi-Strauss na análise do parentesco. Em outras palavras, o significante lacaniano deriva diretamente de seu contato com a análise dos mitos tal qual proposta por Lévi-Strauss. Estes fatores, fazem com que Lacan reproduza os termos empregados pelo antropólogo em A estrutura dos mitos (1955), ao apresentar, em seu quarto seminário, o método de apreensão dos significantes presentes na fala de um paciente.

Um segundo fator a ser considerado é o fato de que o registro de estrutura apresentado na fórmula canônica, por sua articulação entre ao menos dois planos assimétricos e heterogêneos, poderia ser considerado um meta-modelo de formalização 
de todo o projeto lacaniano de apreensão formal da experiência clínica. Esta hipótese, saliento, necessita de mais desenvolvimentos sobre a modulação matemática ai impressa, assim como os detalhes da topologia inerente a tal construto. Entretanto, se assim demonstrado, seu estudo não apenas constituiria um marco central para a compreensão da obra lacaniana, como marcaria uma retomada do franco diálogo da produção psicanalítica com o pensamento de Lévi-Strauss.

A terceira incidência do modelo da fórmula dos mitos sobre a obra lacaniana está na modo como ele articula aí a dimensão do impossível na rede significante, tal qual expresso pela dupla torção final. Acompanhamos algumas vertentes desse significante heterogêneo no pensamento de Lacan, o que nos possibilitou rever e acarar algumas particularidades de seu estatuto no conjunto do sistema do antropólogo. Esta via de leitura, nos permitiu rever o valor do quarto elemento no mito de Édipo e do caso do mito individual do Homem dos Ratos, de modo a explicitar a dupla determinação que permeia tal significante: se por um lado, ele mostra-se como um significante, portanto, inscrito em uma lógica simbólica, de oposição e correlação, por outro, ele marca, em seu modo de articular a cadeia, uma posição limítrofe na ordem simbólica, que demonstra as declinações da lógica do registro do real sobre a série significante.

Para concluir, estou certo de que a presente pesquisa não esgota as dimensões e problemáticas impostas pelo tema. O desejo fundamental de uma ampla retomada dos termos centrais ao diálogo entre a antropologia e a psicanálise, em especial pela via do mito, ainda não teve suas consequências lógicas plenamente extraídas, assim como seu valor justamente dimensionado para o conjunto da obra de ambas as disciplinas. Espero que este trabalho, com suas modestas contribuições, sirva como um ponto de partida para esta frutífera empreitada. Enfim, espero que este percurso pelas incidências fronteiriças do mito possa ter ao menos reposicionado as condições da experiência psicanalítica para que esta não mais seja "uma experiência que esquece seus termos". 


\section{REFERÊNCIAS BIBLIOGRÁFICAS}

ALMEIDA, M. B. (1990) Symmetry and Entropy: Mathematical Metaphors in the Work of Levi-Strauss, Current Anthropology, Vol. 31, No. 4 (Ago. - Out., 1990), pp. $367-385$.

. (2008) A fórmula canônica do mito, In: QUEIROZ, R.; NOBRE, R. (Org.)

Lévi-Strauss - Leituras brasileiras, Belo Horizonte: UFMG, 2008. pp. 147-185.

ARISTOTELES, Poética, In: Os Pensadores, v.4, São Paulo: Abril Cultural,1973.

BARROS, M. L.; BAIRRÃO, J. F. M. H. (2010) Etnopsicanálise: embasamento crítico sobre teoria e prática terapêutica. Revista da SPAGESP - Sociedade de Psicoterapias Analíticas Grupais do Estado de São Paulo Jan.-Jun., Vol. 11, No. 1, p. 45-54.

BARTHES, R. (1957) Mitologias, Rio de Janeiro: Difel, 2010.

BEIVIDAS, W. (2001) Inconsciente et Verbum, São Paulo: Edusp, 2004

BERCHERIE, P. (1980) Los fundamentos de la clínica - Historia y estructura del saber psiquiátrico. Buenos Aires: Manatial, 2005.

BOAS, F. (1887) Os princípios da classificação etnológica, In: . (1999) A

Formação da Antropologia Americana, 1883-1911: Antologia, Rio de Janeiro: UFRJ Editora, 2004.

. (1896) The limitations of the comparative method of anthropology, In:

Race, Language and Culture, New York: The MacMillan Company, 1940.

. (1911) Handbook of American Indian Lenguages, Part 1, Washington: Government Printing Office, 1911. . (1920) The methods of ethnology, In: Race, Language and Culture, New York: The MacMillan Company, 1940. 
BOON, J.; SCHNEIDER, D. (1974) Kinship vis-a-vis Myth Contrasts in Lévi-Strauss Approaches to Cross-Cultural Comparison, American Anthopologist, v.76, pp. 799817.

BORCH-JACOBSON, M. (1994) Lacan - El Amo Absoluto, Buenos Aires: Manantial, 2005.

CANON, W. (1942) "Voodoo" Death In: American Anthropologist, v. 44, pp. 169184.

CARNEIRO DA CUNHA, M. (2008) Um difusionismo estruturalista existe? LéviStrauss e a interface. In: Cultura com Aspas e Outros Ensaios, São Paulo: Cosac Naify, 2009.

CARROLL, M. (1978) Lévi-Strauss on the Oedipus Myth: a reconsideration, American Anthropologist, Vol. 80, No. 4 (Dec., 1978), pp. 805-814

CHAUÍ, M. (2000) Convite à Filosofia, São Paulo: Editora Ática, 2005.

CHERTOK, L.; STEngerS, I. (1989) O Coração e a Razão - A Hipnose de Lavoisier a Lacan, Rio de Janeiro: Jorge Zahar Editor, 1990.

CLÉMENT, C. (2002) Claude Lévi-Strauss, Lisboa: Edições 70, 2004.

COTÉ, A. (1989) L’instauration sociale. Du schème canonique à la formule canonique. In: Anthropologie et Societés, v.13, No. 3, 1989.

(1995) Qu'est-ce que la formule canonique? L'Homme, Paris, v. 35, n¹35 - La formule canonique des mythes, 1995.

COTE, 2001

DA MATTA, R. (1983) Repensando E. R. Leach, In: LEACH, E. Edmund Leach: Antropologia, Organizado por Roberto Da Matta, São Paulo : Ática, 1983.

DELEUZE, G. (1971) Em que se pode reconhecer o estruturalismo? In: A Ilha Deserta, Iluminuras, 2008. 
DELRIEU, A. (2004) Le mythe dans le corpus freudien, In: ZAFIROPOULOS, M.; BOCCARA, M. Lé mythe : pratiques, récits, théories - Volume 4 : Anthropologie et psychanalyse, Paris : Economica, 2004.

DESCOMBES, V. (1979) L’Équivoque du symbolique, MLN, Vol. 94, No. 4, French Issue: Perspectives in Mimesis (Maio, 1979), pp. 655-675

DEVAUX, E. (1995) Groupe de Klein et formule canonique. In: L'Homme, 1995, tomo $35 n^{\circ} 135$

.pp. 43-49.

DEVEREUX, G. (1953) Géza Róheim 1891-1953,In: American Anthropologist, Vol. 55, No. 3 (Ago, 1953), p. 420

DOMICIANO, J. F. G. M. S. (2013) As palavras torcidas do xamã e as experiências produtivas de indeterminação: notas preliminares a uma releitura da homologia entre xamanismo e psicanálise. In: LEITE, N; SOUZA JR, P. (Org.) Psicanálise e Mal-estar na Universidade, Campinas: Mercado das Letras, 2013.

DOMICIANO, J. F. G. M. S. ;DUNKER, C. I. L. (2010) O erro de Roudinesco, In: X Jornada Corpolinguagem e III Encontro Outrarte, Campinas: UNICAMP, 2010.

DOMINGUES, I. A América de Lévi-Strauss, São Paulo: Edições Loyola, 2012.

DÖR, J. (1989) O Pai e sua Função em Psicanálise, Rio de Janeiro: Jorge Zahar Editor, 2012.

DOSSE, F. (1992) História do Estruturalismo: o campo do signo, Bauru: Edusc, 2007.

DRACH, M.; TOBOUL, B. (Org.) L’Anthropologie de Lévi-Strauss et la Psychanalyse - D'une structure 1'autre, Paris: La Découverte, 2008.

DUBAR, C. (1969) La méthode de Marcel Mauss, In: Revue Française de Sociologie, v.10, No. 4 (out-dez 1969), pp.515-52.

DUMONT, L. (1971) Homo Hierarquicus - O Sistema de Casta e Suas Implicações, São Paulo, Edusp, 1995. 
DUNKER, C. I. L. (2001) Clínica, linguagem e subjetividade. In: Distúrbios da Comunicação. v.12, p.39-61.

. (2006) Estruturas clínicas e constituição do sujeito In: O que a psicanálise pode ensinar sobre a criança, sujeito em constituição. São Paulo: Escuta, 2006, p. 121-140.

(2008) A psicanálise em seu tempo In: Encontro Nacional do Fórum do Campo Lacaniano, São Paulo, 2008.

Estrutura e Constituição da Clínica Psicanalítica: uma arqueologia das práticas de cura, psicoterapia e tratamento. São Paulo: Annablume, 2011.

A Psicose na Criança - Tempo, Linguagem e Sujeito, São Paulo: Zagodoni, 2013

ELIADE, M. (1962) The History of Religions in Retrospect: 1912-1962, In: Journal of Bible and Religion, Vol. 31, No. 2 (Abr., 1963), pp. 98-109

ELLENBERGER, H. The Discovery of Unconscious: The History and Evolution of Dynamic Psychiatry. New York: Basic Books, 1970.

ELLIOT-SMITH, G. (1926) Introduction, In: RIVERS (1926) Psychology and Etnology, London: Kegan Paul, 1926.

EVANS, R.; KOELSH, W. (1985) Psychoanalysis arrives in America - The 1909 conference at Clark University, American Psychologist, v.40, No.3, pp.942-48

FERENCZI, S. (1920) Matemática, In: (1992) Psicanálise IV, São Paulo: Martins Fontes, 2011.

FINK, B. (2002) Knowledge and Jouissance, In: BARNARD, S.; FINK, B. Reading Seminar XX : Lacan's major work on love, knowledge, and feminine sexuality, New York: State University of New York Press, 2002.

- Fundamentals of psychoanalytic technique: A lacanian approach for practitioners, New York: Norton \& Company, 2007 
FOUCAULT, M. (1963) O Nascimento da Clínica, Rio de Janeiro: Forense Universitária, 1977

. (1966) As Palavras e as Coisas, São Paulo: Martins Fontes, 2009

FREUD, S. (1885-6) Relatório sobre meus estudos em Paris e Berlim, In: Obras Completas, v.I, Rio de Janeiro: Imago, 1976.

. (1888) Histeria, In: Obras Completas, v.I, Rio de Janeiro: Imago, 1976.

. (1890) Tratamento psíquico (ou anímico), In: Obras Completas, v.VII, Rio de Janeiro: Imago, 1976.

. (1891) Sobre a Concepção das Afasias - Um Estudo Crítico, São Paulo: Autêntica, 2013.

. (1893) Sobre o mecanismo psíquico de fenômenos histéricos: comunicação preliminar In: Obras Completas, v.II, Rio de Janeiro: Imago, 1976

. (1897) Cartas a Fliess - Carta 69 In: Obras Completas, v.III, Rio de Janeiro: Imago, 1976

. (1897) Cartas a Fliess - Carta 71 In: Obras Completas, v.III, Rio de Janeiro: Imago, 1976

- (1900) A Interpretação dos Sonhos, In: Obras Completas, v.IV, Rio de Janeiro: Imago, 1976.

. (1902) Psicopatologia da Vida Cotidiana, In: Obras Completas, v.VI, Rio de Janeiro: Imago, 1976.

. (1905) Sobre a psicoterapia, In: Obras Completas, v.VII, Rio de Janeiro: Imago, 1976

. (1907) O esclarecimento sexual das crianças, In: Obras Completas, v.IX, Rio de Janeiro: Imago, 1976.

. (1908a) Escritores criativos e devaneios, In: Obras Completas, v.IX, Rio de Janeiro: Imago, 1976. 
. (1908b) Sobre as teorias sexuais infantis: In: Obras Completas, v.IX, Rio de Janeiro: Imago, 1976.

. (1909) Notas sobre um caso de neurose obsessiva, In: Obras Completas, v.X, Rio de Janeiro: Imago, 1976

. (1911) Notas psicanalíticas sobre um relato autobiográfico de um caso de paranoia (Dementia paranoides) In: Obras Completas, v.XII, Rio de Janeiro: Imago, 1976

. (1912) A dinâmica da transferência, In: Obras Completas, v.XII, Rio de Janeiro: Imago, 1976.

. (1913 [1912-13]) Totem e Tabu, In: Obras Completas, v.X, Rio de Janeiro: Imago, 1976

. (1914) Recordar, repetir e elaborar, In: Obras Completas, v.XII, Rio de Janeiro: Imago, 1976.

. (1915) O inconsciente, In: Obras Completas, v.XIV, Rio de Janeiro: Imago, 1976.

. (1916) Conferência X, In: Obras Completas, v.XV, Rio de Janeiro: Imago, 1976.

. (1917) Conferência XVIII - Terapia analítica, In: Obras Completas, v.XVI, Rio de Janeiro: Imago, 1976

- (1927) Um estudo autobiográfico, In: Obras Completas, v.XX, Rio de Janeiro: Imago, 1976.

. (1939) Moisés e o monoteísmo: três ensaios, In: Obras Completas, v.XXIII, Rio de Janeiro: Imago, 1976.

GARCIA-ROZA, A. (1983) Freud e o inconsciente, Rio de Janeiro: Jorge Zahar Ed., 1994

GAY, P. (1988) Freud - Uma Vida para nosso Tempo, São Paulo: Companhia das Letras, 2005 
GEORGIN, R. (1983) Lacan y Lévi-Strauss, Buenos Aires, Letra Viva, 1995.

GOLDMAN, M. (2005) Lévi-Strauss, a ciência e as outras coisas, In: QUEIROZ, R. e NOBRE, R. (Org.) Lévi-Strauss - Leituras brasileiras, Belo Horizonte: UFMG, 2008. p. $41-80$

HANNS, L. Dicionário do Alemão de Freud, Rio de Janeiro: Imago, 1996.

HOLMER, N. M.; WASSEN, H. Mu-Igala or the Way of Muu, a Medecine Song from the Cuna of Panama, Göteborg: Ethnografista Museet. 1947

HOLMER, N. M. et WASSEN, H. The Complete Mu-Igala in Picture Writing. A Native Record of a Cuna Medicine Song, Göteborg: Ethnografista Museet, 1953

JONES, E. (1925) Mother-Right and the Sexual Ignorance of Savages, In: The International Journal of Psycho-Analysis, Vol. 6, No. 2, pp. 109-130.

KLEIMAN, A. Patients and Healers in the Context of Culture. Berkeley: University of California Press, 1980

KROEBER, A. (1920) Totem and taboo: an ethnologic psychoanalysis, In: American Anthropologist, v.22, 1920, pp. 48-55

LACAN, J. (1936) Para-além do princípio de realidade, In: Escritos, Rio de Janeiro: Jorge Zahar Ed. 1998.

(1938) Os complexos familiares na formação do indivíduo, In: Outros Escritos, Rio de Janeiro: Jorge Zahar Ed. 2003.

. (1946) Formulações sobre a causalidade psíquica, In: Escritos, Rio de Janeiro: Jorge Zahar Ed. 1998.

. (1949) O estádio do espelho como formador da função do eu, In: Escritos, Rio de Janeiro: Jorge Zahar Ed. 1998.

. (1950) Introdução teórica às funções da psicanálise em criminologia, In: Escritos, Rio de Janeiro: Jorge Zahar Ed. 1998. 
. (1951) Some reflections on the ego, In: International Journal of psychoanalysis, volume 34, 1953, pp. 11-17.

. (1953a) O mito individual do neurótico ou Poesia e verdade na neurose, In: O Mito Individual do Neurótico, Rio de Janeiro: Jorge Zahar Ed., 2008.

. (1953b) Função e campo da fala e da linguagem, In: Escritos, Rio de Janeiro: Jorge Zahar Ed. 1998, pp. 238-324

O Seminário - Livro I: Os Escritos Técnicos de Freud (1953-54), Rio de Janeiro: Jorge Zahar Ed. 2002.

O Seminário - Livro II: O Eu na Teoria de Freud (1954-55), Rio de Janeiro: Jorge Zahar Ed. 2004.

. (1955) O seminário da Carta Roubada, In: In: Escritos, Rio de Janeiro: Jorge Zahar Ed. 1998.

- (1956) Intervenção depois de uma exposição de Claude Lévi-Strauss na Sociedade Francesa de Filosofia, "Sobre as relações entre a mitologia e o ritual, com uma resposta dele", In: O Mito Individual do Neurótico, Rio de Janeiro: Jorge Zahar Ed. 2008.

. O Seminário - Livro III: As Psicoses (1955-56), Rio de Janeiro: Jorge Zahar Ed. 2000.

. O Seminário - Livro IV: A Relação de Objeto (1956-57), Rio de Janeiro: Jorge Zahar Ed. 2003.

- (1957) A instância da letra no inconsciente ou a razão desde Freud, In: Escritos, Rio de Janeiro: Jorge Zahar Ed. 1998, p.496-535

. (1958) A direção do tratamento e os princípios de seu poder, In: Escritos, Rio de Janeiro: Jorge Zahar Ed. 1998, p.591-652

O Seminário - Livro V: As Formações do Inconsciente (1957-58), Rio de Janeiro: Jorge Zahar Ed. 2004. 
. O Seminário - Livro VII: A Ética da Psicanálise (1959-60), Rio de Janeiro: Jorge Zahar Ed. 2006.

. O Seminário - Livro VIII: A Transferência (1960-61), Rio de Janeiro: Jorge Zahar Ed. 2007.

. O Seminário - Livro X: A Angústia (1962-63), Rio de Janeiro: Jorge Zahar Ed. 2004.

. O Seminário - Livro XII: Problemas Cruciais para a Psicanálise (196465), Recife: Centro de Estudos Freudianos de Recife, 2006.

. (1966) A ciência e a verdade, In: Escritos, Rio de Janeiro: Jorge Zahar Ed. 1998, p.869-890

. O Seminário - Livro XVI: De um Outro ao outro (1968-69), Rio de Janeiro: Jorge Zahar Ed. 2008.

O Seminário - Livro XVII: O Avesso da Psicanálise (1969-70), Rio de Janeiro: Jorge Zahar Ed. 2009.

. (1970) Radiofonia, In: Outros Escritos, Rio de Janeiro: Jorge Zahar Ed. 2003.

O Seminário - Livro XVIII: De um Discurso que não Fosse do Semblante (1970-71), Rio de Janeiro: Jorge Zahar Ed. 2011.

. O Seminário - Livro XIX: ... Ou Pior (1971-72), Recife: Centro de Estudos Freudianos de Recife, 2006.

O Seminário - Livro XX: Mais, Ainda (1972-73), Rio de Janeiro: Jorge Zahar Ed. 2010.

. (1973) Televisão, In: Outros Escritos, Rio de Janeiro: Jorge Zahar Ed. 2003.

LANGDON, J. (1994) A negociação do oculto: Xamanismo, família e medicina entre os Siona no contexto pluri-étnico. Tese (Concurso de Professor Titular) Florianópolis: UFSC.

LAPLANCHE, J (1974) Vocabulário de Psicanálise, São Paulo: Martins Fontes, 2004 
LAPLANTINE, F. (1987) Aprender Antropologia, São Paulo: Brasiliense, 2000.

LEACH, E. (1957) Man and Culture. An Evaluation of the Work of Bronislaw Malinowski, Londres: Routledge \& Kegan Paul, 1957.

LEACOCK, S. (1954) The Ethnological Theory of Marcel Mauss, American Anthropologist, New Series, Vol. 56, No. 1 (Fev, 1954), pp. 58-73

LÉVI-STRAUSS, C. (1945) Análise estrutural em linguística e em antropologia, In: Antropologia Estrutural, São Paulo: Cosac Naify, 2009.

. (1949a) As Estruturas Elementares do Parentesco, São Paulo: Vozes, 2009.

. (1949b) A eficácia simbólica, In: Antropologia Estrutural, São Paulo: Cosac Naify, 2009.

. (1949c) O feiticeiro e sua magia, In: Antropologia Estrutural, São Paulo: Cosac Naify, 2009.

. (1949d) Etnologia e história, In: Antropologia Estrutural, São Paulo: Cosac Naify, 2009.

. (1950) Introdução à Obra de Marcel Mauss In: MAUSS, M. (1950) Sociologia e antropologia, São Paulo: Cosac Naify, 2005

. (1952) As organizações dualistas existem? In: Antropologia Estrutural, São Paulo: Cosac Naify, 2009

(1952) A noção de estrutura em etnologia, In: Antropologia Estrutural, São Paulo: Cosac Naify, 2009.

(1952-53) Pesquisas de mitologia ameríndia, In: (1983) Minhas

Palavras, São Paulo: Brasiliense, 1988.

- (1954) Lugar da antropologia nas ciências sociais, In: Antropologia Estrutural, São Paulo: Cosac Naify, 2009. . (1955) A estrutura dos mitos, In: Antropologia Estrutural, São Paulo: Cosac Naify, 2009. 
. (1956) Estrutura e Dialética, In: Antropologia Estrutural, São Paulo: Cosac Naify, 2009.

. (1958) Antropologia Estrutural, São Paulo: Cosac Naify, 2009.

. (1960) Aula inaugural, In: LIMA, L.C. O Estruturalismo de Lévi-Strauss, São Paulo: Vozes, 1968

. (1962) O Pensamento Selvagem, Campinas: Papirus, 2010

. (1962a) Totemismo Hoje, São Paulo: Abril Cultural, 1973.

. (1964) O Cru e o Cozido, São Paulo: Cosac Naify, 2004

. (1967) Do Mel às Cinzas, São Paulo: Cosac Naify, 2005

. (1971) O Homem Nu, São Paulo: Cosac Naify, 2012.

. (1978) Mito e Significado, Lisboa: Edições 70, 1984

. (1983) Minhas Palavras, São Paulo: Brasiliense, 1988.

. (1985) A Oleira Ciumenta, Lisboa: Edições 70, 1987

. (1988) De Perto e de Longe, São Paulo: Cosac Naify, 2005

(2001) Hourglass configurations, In: In: MARANDA, P. (Org.) The Double

Twist: From Ethnografy to Morphodynamics, Toronto: University of Toronto Press, 2001.

LÉVY-BRUHL, L. (1922) La Mentalité Primitive, Paris: Les Presses Universitaires de France, 1960.

LUKÁCS, G. (1962) A Teoria do Romance, São Paulo: Editora 34. 2007.

MALINOWSKI, B. (1922) Argonauts of the Western Pacific, London: Routledge, 2002.

. (1927) Sex and Repression in Savage Society . Londres: Kegan Paul, Trench, Trubner \& Co.. 
. (1929) A Vida Sexual dos Selvagens. Rio de Janeiro: Francisco Alves, 1982.

MANNONI, O. (1976) Freud e a psicanálise, Rio de Janeiro: Editora Rio, 1988.

MARANDA, P. Structural Models in Folklore and Transformational Essays, Québec: Mouton, (1971)

(Org.) The double twist: from ethnography to morphodynamics, Toronto: University of Toronto Press, 2001

MARTINS, P. H. (2005) A sociologia de Marcel Mauss: dádiva, simbolismo e associação, In: Revista Crítica de Ciências Sociais, Vol. 75 (Dez 2005), pp.45-66.

MAUSS, M. (1904) Esboço de uma teoria geral da magia, In: Sociologia e Antropologia, São Paulo: Cosac Naify, 2003.

- (1906) Ensaio sobre as variações sazonais das sociedades esquimós, In: Sociologia e Antropologia, São Paulo: Cosac Naify, 2003.

. (1924) Relações reais e práticas entre a psicologia e sociologia, In: Sociologia e Antropologia, São Paulo: Cosac Naify, 2003.

(1925) Ensaio sobre a dádiva, In: Sociologia e Antropologia, São Paulo: Cosac Naify, 2003.

. (1935) As técnicas do corpo, In: Sociologia e Antropologia, São Paulo: Cosac Naify, 2003.

MEHLMAN, J. (1972) The "Floating Signifier": From Lévi-Strauss to Lacan, In: Yale French Studies, No. 48, 1972, pp. 10-37

MEZAN, R. (1985) Freud, Pensador da Cultura, São Paulo: Companhia das Letras, 1996.

. (1989) Freud - A Trama dos Conceitos, São Paulo: Perspectiva, 2001.

MICELA, R. Antropologia e Psicanálise, São Paulo: Brasiliense, 1982.

MILLER, J.-A. (1998) Quadro comentado das representações gráficas, In: Escritos, Rio de Janeiro: Jorge Zahar Ed. 1998. 
MOSKO, M. The Canonic Formula of Myth and Nonmyth In: American Ethnologist, v. 18, n 1, fev. 1991, p. 126-151. Disponível em: < http://www.jstor.org/stable/645568> Acessado em: 04 abr. 10

NOBUS, D. Jacques Lacan and the Freudian Practice of Psychoanalysis. Londres: Routledge, 2000.

OGILVIE, B. Lacan: a formação do conceito de sujeito (1932-1949), Rio de Janeiro: Jorge Zahar, 1991.

PARKER, I. (2011) Psicanálise Lacaniana, São Paulo, Annablume, 2013.

PERRIN, M. Le chamanisme, Paris: PUF, 1995

PORGE, E. (2009) Transmitir a clínica psicanalítica, Campinas: Unicamp, 2011.

PULMAN, B. (1986) Aux Origines du débat ethnologie/ psychanalyse : W. H. R. Rivers (1824-1922). In: L'Homme, 1986, tome 26, n¹00. pp. 119-142.

. (2004) Malinowski and Ignorance of Physiological Paternity, In: Revue française de sociologie, Vol.45, pp.145-66.

QUINET, A. (2009a) Com lalíngua no corpo, Stylos - Revista de Psicanálise, No. 19, São Paulo : EPFCL.

. (2009b) Óidipous, o inconsciente em cena, Comunicação de Pesquisa, Rio de Janeiro, UVA.

RACINE, L. (2001) Analogy and the canonical formula of mythic transformations, In: In: MARANDA, P. (Org.) The Double Twist: From Ethnografy to Morphodynamics, Toronto: University of Toronto Press, 2001.

RECHMAN, R. (2002) Anthropologie et psychanalyse : un débat hors sujet? In: DRACH, M.; TOBOUL, B. (Org.) L’Anthropologie de Lévi-Strauss et la Psychanalyse - D'une structure l'autre, Paris: La Découverte, 2008.

RIVERS, W. H. R. Instinct and the Unconscious. Cambridge: Cambridge University Press. 1920 
. (1924) Medicine, Magic and Religion, London: Routledge, 2001

Psychology and Etnology, London: Kegan Paul, 1926.

RIVIÈRE, C. Introdução à Antropologia, Lisboa : Edições 70, 1995

ROHÉIM, G. (1947) Psychoanalysis and The Social Sciences, London: Holly Press, 2001.

- (1948) Psicanálise e antropologia, In: LORAND, S. (1950) A Moderna

Psicanálise, Rio de Janeiro: Gertrum Editora, 1962.

ROSSI, I. (1973) The unconscious in the Anthropology of Claude Lévi-Strauss, In: American Anthropologist, Vol. 75, No.1, pp.20-48

ROUDINESCO, É. (1994) Lacan - Esbozo de una vida, historia de un sistema de pensamiento, Buenos Aires: Fondo de Cultura Económica, 2005 . (1998) Préface, In: DEVEREUX, G. (1951) Psychothérapie d'un Indien des Plaines, Paris: Fayard, 1998.

ROUDINESCO, É.; PLON, M. (1997) Dicionário de Psicanálise, Rio de Janeiro: Jorge Zahar Ed., 1998.

SAFATLE, V. A paixão do negativo - Lacan e a dialética, São Paulo: Unesp, 2004.

SERRA, O. O Reinado de Édipo, Brasília: Editora da UNB, 2007.

SCUBLA, L. (2001) Hesiod, the three functions, and the canonical formula of mith, In: In: MARANDA, P. (Org.) The Double Twist: From Ethnografy to Morphodynamics, Toronto: University of Toronto Press, 2001.

SÉCHEHAYE, M. (1950) Diário de uma Esquizofrênica, Rio de Janeiro: Nova Fronteira, 1973.

SIMANKE, R. T. Metapsicologia Lacaniana - Os anos de formação, Curitiba: Editora UFPR, 2002 
STOCKLER, M. (2005) Por que a identidade não pode durar - a troca entre LéviStrauss e os índios, In: QUEIROZ, R.; NOBRE, R. (Org.) Lévi-Strauss - Leituras brasileiras, Belo Horizonte: UFMG, 2008.

STOCKING, G, (1999) Os pressupostos básicos da antropologia de Boas, In: BOAS, F. (1999) A Formação da Antropologia Americana, 1883-1911: Antologia, Rio de Janeiro: UFRJ Editora, 2004.

STRAUSS, M. (2008) Lévi-Strauss lecteur de Freud, Lacan lecteur de Lévi-Strauss, In: DRACH, M.; TOBOUL, B. (Org.) L’Anthropologie de Lévi-Strauss et la Psychanalyse - D’une structure 1'autre, Paris: La Découverte, 2008.

SZTUTMAN (2005) Sobre a ação xamânica, In: Redes de Relações nas Guianas, São Paulo: Humanitas, 2005

SCHWIMMER, E. (2001) Is the canonic formula useful in cultural description? In: MARANDA, P. (Org.) The Double Twist: From Ethnografy to Morphodynamics, Toronto: University of Toronto Press, 2001.

TYLOR, E. B. Primitive Culture: Researches Into the Development of Mythology, Philosophy, Religion, Art, and Custom. Boston: John Murray, 1891.

VERNANT, J.-P. (1981) O tirano coxo: de Édipo a Periandro", In: VERNANT; VIDAL NAQUET, P. (1994) Mito e Tragédia na Grécia Antiga, Ed. Perspectiva, São Paulo, 1995

. (2002) Entre Mito e Política, São Paulo, Edusp, 2004.

VEYNE, P. (1983) Acreditavam os Gregos em seus Mitos? São Paulo: Brasiliense, 1984.

VIEIRA, T. (2009) Édipo rei: entre a razão e o daimon, In: Édipo Rei de Sófocles, São Paulo: Perspectiva, 2009.

VIVEIROS DE CASTRO, E. (1996) O conceito de sociedade em antropologia, In: A Inconstância da Alma Selvagem, São Paulo: Cosac Naify, 2002. 
. (1999) O problema da afinidade na Amazônia, In:

A Inconstância da

Alma Selvagem, São Paulo: Cosac Naify, 2002.

. (2002) O nativo relativo. Mana, v.18, n.1, Rio de Janeiro, abril, p. 113-148.

(2008) Xamanismo transversal - Lévi-Strauss e a cosmopolítica amazônica, In:

QUEIROZ，R.; NOBRE， R. (Org.) Lévi-Strauss - Leituras brasileiras, Belo Horizonte: UFMG, 2008. p. 79-130.

ZAFIROPOULOS, M. Lacan y las Ciências Sociales - el declínio del padre (1938 1953), Buenos Aires: Nueva Visión, 2001

. (2003) L’universalité de l'OÉdipe. Lacan et Lévi-Strauss: le mythe individuel du névrosé. In: ZAFIROPOULOS, M. ; BOCCARA, M. Lé mythe : pratiques, récits, théories - Volume 4 : Anthropologie et psychanalyse, Paris : Economica, 2004 (2004)

Lacan y Lévi-Strauss - o el retorno a Freud (1951-1957), Buenos Aires:

Manantial, 2006 